\title{
GROUND-WATER CONDITIONS IN GEORGIA, 1990
}

By Barbara J. Milby, Charles N. Joiner, Alan M. Cressler, and Christopher T. West

U.S. GEOLOGICAL SURVEY

OPEN-FILE REPORT 91-486

Prepared in cooperation with

GEORGIA DEPARTMENT OF NATURAL RESOURCES

ENVIRONMENTAL PROTECTION DIVISION

GEORGIA GEOLOGIC SURVEY

ALBANY WATER, GAS, AND LIGHT COMMISSION

CITY OF BRUNSWICK

GLYNN COUNTY

CHATHAM COUNTY-SAVANNAH METROPOLITAN PLANNING COMMISSION

CITY OF VALDOSTA

Doraville, Georgia 


\title{
U.S. DEPARTMENT OF THE INTERIOR MANUEL LUJAN, JR., Secretary
}

\author{
U.S. GEOLOGICAL SURVEY \\ Dallas L. Peck, Director
}

For additional information write to:

District Chief U.S. Geological Survey 6481-B Peachtree Industrial Blvd. Doraville, GA 30360
Copies of this report may be purchased from:

U.S. Geological Survey Books and Open-File Reports Federal Center Denver, CO 80225 


\section{CONTENTS}

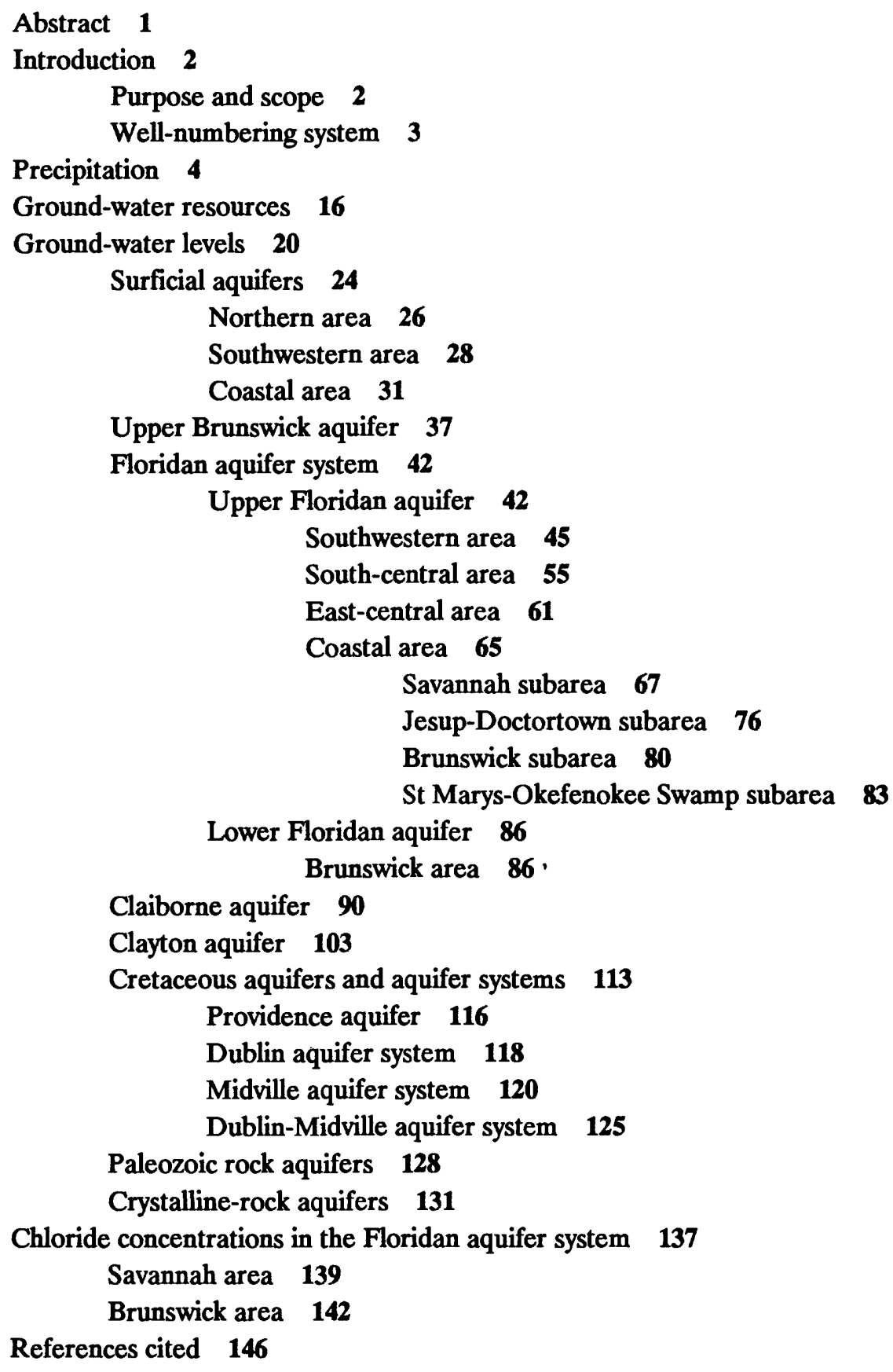




\section{ILLUSTRATIONS}

Figure 1. Map showing locations of precipitation monitoring stations and mean annual precipitation in Georgia, 1941-70 5

Figures 2.-11. Graphs showing precipitation departure from normal for National Weather Service station:

2. Athens airport, Clarke County 6

3. Atlanta airport, Fulton County 7

4. Rome, Floyd County 8

5. Albany 3 SE, Dougherty County 9

6. Augusta airport, Richmond County 10

7. Clayton 1 SSW, Rabun County 11

8. Cleveland, White County 12

9. Columbus airport, Muscogee County 13

10. Macon airport, Bibb County 14

11. Savannah airport, Chatham County 15

Figures 12.-14. Maps showing:

12. Areas of utilization of major aquifers and block diagram showing major aquifers and physiographic provinces of Georgia 17

Figure

Figures

13. Locations of observation wells for which hydrographs are included in this report 21

14. Locations of observation wells completed in the surficial aquifers 25

15.-22. Hydrographs showing the water level in observation well:

15. 11AA01, Spalding County 27

16. $13 \mathrm{M} 007$, Worth County 29

17. 07H003, Miller County 30

18. 35P094, Chatham County 32

19. 37P116, Chatham County 33

20. 32R003, Bulloch County 34

21. 34 H438, Glynn County 35

22. 32L017, Wayne County 36

Figure 23. Map showing locations of observation wells completed in the upper Brunswick aquifer 38

Figures 24.-26. Hydrographs showing the water level in observation well:

24. 31U009, Bulloch County 39

25. 32L016, Wayne County 40

26. 34H437, Glynn County 41

Figures 27.-29. Maps showing:

27. Subareas and locations of observation wells completed in the Upper Floridan aquifer 43

28. Water level and locations of observation wells completed in the Upper Floridan aquifer in Georgia and adjacent parts of Alabama, Florida, and South Carolina, May-June 199044

29. Water level and locations of observation wells completed in the Upper Floridan aquifer in the Albany area, October 199046

Figures 30.-39. Hydrographs showing the water level in observation well:

30. 09F520, Decatur County 47

31. 08G001, Miller County 48

32. 06F001, Seminole County 49

33. 13L012, Dougherty County 50

34. 10G313, Mitchell County 51

35. 13L003, Dougherty County 52

36. 13J004, Mitchell County 53

37. $15 \mathrm{~L} 020$, Worth County 54

38. 18K049, Tift County 56

39. 18H016, Cook County 57 


\section{ILLUSTRATIONS--Continued}

Figure

Figures

Figure

Figures

Figure

Figure

Figures

Figure

Figure
Figures

Figures 78.-85. Hydrographs showing the water level in observation well:

40. Map showing the water level and locations of observation wells completed in the Upper Floridan aquifer in the Valdosta area, October 199058

41.-60. Hydrographs showing the water level in observation well:

41. 19E009, Lowndes County 59

42. 19F039, Lowndes County 60

43. 21T001, Laurens County 62

44. 250001, Montgomery County 63

45. 26R001, Toombs County 64

46. Map showing subareas and locations of observation wells completed in the Upper

Floridan aquifer in the coastal area 66

47.-61. Hydrographs showing the water level in observation well:

47. 360008 , Chatham County 68

48. 360020 , Chatham County 69

49. 380002, Chatham County 70

50. 390003, Chatham County 71

51. 32R002, Bulloch County 72

52. 34M054, Liberty County 73

53. 34N089, Liberty County 74

54. 35M013, McIntosh County 75

55. 30L003, Wayne County 77

56. 32L015, Wayne County 78

57. 33M004, Long County 79

58. 33H127, Glynn County 81

59. 33H133, Glynn County 82

60. 33E027, Camden County 84

61. 27E004, Charlton County 85

62. Map showing locations of observation wells completed in the Lower Floridan aquifer 87 63.-64. Hydrographs showing the water level in observation well:

63. 34H391, Glynn County 88

64. 33J044, Glynn County 89

65. Map showing the water level and locations of observation wells completed in the Claiborne aquifer, November 199091

66.-76. Hydrographs showing the water level in observation well:

66. 06K010, Early County 92

67. 09G001, Decatur County 93

68. 09M009, Randolph County 94

69. 11K002, Dougherty County 95

70. 11P015, Lee County 96

71. 15R007, Dooly County 97

72. 11L001, Dougherty County 98

73. 12L019, Dougherty County 99

74. 13L011, Dougherty County 100

75. $13 \mathrm{M} 005$, Worth County 101

76. 14P015, Crisp County 102

77. Map showing the water level and locations of observation wells completed in the Clayton aquifer, November 1990104

78. $06 \mathrm{~K} 009$, Early County 105

79. 07N001, Randolph County 106

80. 09M007, Randolph County 107

81. 09N001, Terrell County 108

82. 11L002, Dougherty County 109

83. 13L002, Dougherty County 110

84. 11K005, Dougherty County 111

85. 14P014, Crisp County 112

86. Map showing locations of observation wells completed in Cretaceous aquifers and aquifer systems 114 


\section{ILLUSTRATIONS--Continued}

Figures 87.-95. Hydrographs showing the water level in observation well:

87. 06S001, Chattahoochee County 115

88. 12L021, Dougherty County 117

89. 18U001, Twiggs County 119

90. 18T001, Pulaski County 121

91. 21U004, Laurens County 122

92. 24V001, Johnson County 123

93. 28X001, Burke County 124

94. 30AA04, Richmond County 126

95. 23X027, Washington County 127

Figure 96. Map showing the location of an observation well completed in a Paleozoic rock aquifer 129

97. Hydrograph showing the water level in observation well 03PP01, Walker County 130

98. Map showing locations of observation wells completed in crystalline-rock aquifers 132

Figures 99.-102. Hydrographs showing the water level in observation well:

99. 10DD02, Fulton County 133

100. 19HH12, Madison County 134

101. 11FF04, DeKalb County 135

102. 21BB04, Greene County 136

Figures 103.-104. Maps showing:

103. Chloride concentration and locations of chloride-monitoring wells completed in the Upper Floridan aquifer in the coastal area, May 1990138

104. Locations of chloride-monitoring wells completed in the Floridan aquifer system in the Savannah area 140

Figure

105. Graphs showing chloride concentrations in the Upper and Lower Floridan aquifers in the Savannah area 141

106. Map showing chloride concentrations in the upper water-bearing zone of the Upper Floridan aquifer and locations of chloride-monitoring wells in the Floridan aquifer system in the Brunswick area, October-November 1990143

Figures 107.-108. Graphs showing:

107. Chloride concentration in the Floridan aquifer system in the southern Brunswick area 144

108. Chloride concentration in the Floridan aquifer system in the northern Brunswick area 145

\section{TABLES}

Table 1. Aquifer and well characteristics in Georgia 18

2. Observation wells for which water-level hydrographs are included in this report 22

3. Observation wells for which chloride-concentration graphs are included in this report 137 


\section{CONVERSION FACTORS AND VERTICAL DATUM}

Multiply

inch (in.)
foot (ft)
mile (mi)
gallon per minute
(gal/min)
million gallons per day
(Mgal/d)
million gallons per day
(Mgal/d)

by

Length

2.540

0.3048

1.609

Volumetric rate

0.06308

0.04381

43.81 to obtain

centimeter

meter

kilometer

liter per second

cubic meters per second

liters per second

Sea Level:--In this report, "sea level" refers to the National Geodetic Vertical Datum of 1929--a geodetic datum derived from a general adjustment of the first-order level nets of both the United States and Canada, formerly called "Sea Level Datum of 1929." 


\title{
GROUND-WATER CONDITIONS
}

\section{IN GEORGIA, 1990}

\author{
By \\ Barbara J. Milby, Charles N. Joiner, \\ Alan M. Cressler, and Christopher T. West
}

\begin{abstract}
Ground-water conditions during 1990 and recent ground-water-level and -quality trends in Georgia were evaluated using data from precipitation, ground-water-level, and ground-water-quality monitoring networks. Data for 1990 include precipitation records from 10 National Weather Service stations, continuous water-level records from 140 wells, periodic water-level measurements from an additional 1,227 wells, and chloride analyses from 176 wells.

Annual mean ground-water levels in Georgia in 1990 ranged from about 11.4 feet lower to about 3.2 feet higher than in 1989. Of the 76 wells summarized in this report, 24 had annual mean water levels that were higher than in 1989. Record-high daily mean water levels were recorded in three wells tapping the Claiborne aquifer and two wells tapping crystalline-rock aquifers. These record highs were from about 0.4 to about 5.0 feet higher than previous record highs. The other 52 wells had annual mean water levels that were lower than in 1989. Record-low daily mean water levels were recorded in the Coastal Plain physiographic province in two wells tapping surficial aquifers, one well tapping the upper Brunswick aquifer, 21 wells tapping the Floridan aquifer system, one well tapping the Claiborne aquifer, one well tapping the Clayton aquifer and seven wells tapping the Cretaceous aquifers and aquifer systems. These record lows were from slightly lower to about 7.8 feet lower than the previous record lows.

Comparison of chloride-concentration maps for the Floridan aquifer system in the coastal area indicates that chloride concentrations in water from the Floridan aquifer system generally have changed little since 1988. In the coastal area, chloride concentrations in water from the Upper Floridan aquifer that exceed U.S. Environmental Protection Agency and Georgia Department of Natural Resources, Environmental Protection Division, drinking-water standards have been detected only in the Brunswick area.

In the Brunswick area, changes in chloride concentrations in water from the Floridan aquifer system have been mixed. In the southern Brunswick area, chloride concentration in water from the Lower Floridan aquifer has increased gradually since sampling began in the late 1960's. In the northeastern Brunswick area, water in two wells tapping the Upper Floridan aquifer showed trends of decreasing chloride concentrations that began in 1980 and 1984. In the northwestern Brunswick area, water in two wells tapping the Upper Floridan aquifer showed trends of increasing chloride concentrations that have been present since sampling began in 1970. In the Savannah area, chloride concentrations have shown little change since 1968, except for an increase in three wells tapping deep zones of the Lower Floridan aquifer at the end of 1990.
\end{abstract}




\section{INTRODUCTION}

Monitoring ground-water levels and quality is essential to water-resources management. Groundwater levels and quality have been monitored in Georgia for about 100 years. In the early years, water-level data were used in areal reconnaissance studies to show water-level trends. These data had hited value for resource-management purposes because of the large period of time between collection and publication of the data.

As part of the cooperative ground-water investigations undertaken by the U.S. Geological Survey and the state of Georgia, a statewide water-level-measurement program was begun in 1938. Initially, this prograin consisted of an observation-well network in the coastal area of Georgia that provided data concerning variations in ground-water storage and quality. Additional wells were added in areas where variations in water levels and water quality could forewarn potential water-resources problems. During 1990, periodic water-level measurements were made in 1,227 wells, and 140 wells were monitored continuously. Continuous water-level records were obtained using analog (pen and chart) recorders, digital punch recorders that record water levels at 30 -minute ( $\mathrm{min}$ ) or 60 -min intervals, and data loggers that record water levels at 60 -min intervals. At sites with missing record, data were estimated, where possible, using data from nearby wells that showed a similar water-level response to variations in precipitation and pumping. Water samples also were periodically collected and analyzed from 176 wells during 1990 to monitor chloride concentrations in the coastal area.

\section{Purpose and Scope}

Ground-water-level and -quality data are an important part of ground-water assessment and management. Water-level data are used to indicate directions of ground-water flow and areas of recharge and discharge; indicate the change in aquifer storage as it is affected by distribution and rate of ground-water withdrawal; help define the hydraulic characteristics of aquifers; evaluate strean-aquifer relations; provide information for addressing water-management needs; and provide long-term records that can be used to evaluate the effects of management and conservation prograns.

This report continues a series of annual publications that present precipitation, ground-water-level, and ground-water-quality information for Georgia. Formerly titled "Ground-Water Data for Georgia", the title was changed to "Ground-Water Conditions in Georgia" in 1989 to more accurately reflect its content. Precipitation graphs for 10 National Weather Service stations, hydrographs for 76 wells, and water-level maps of the Upper Floridan, Claiborne, and Clayton aquifers are presented to illustrate the effects that variations in recharge and discharge have had on the various aquifers in the State. Chloride-concentration graphs for $\mathbf{1 3}$ wells tapping the Floridan aquifer system in the coastal area, and chloride-concentration maps for the Upper Floridan aquifer in the coastal and Brunswick areas, have been included to show the distribution and variations in chloride concentration since monitoring began. 


\section{Well-Numbering System}

Wells described in this report are numbered according to a system based on the U.S. Geological Survey index of topographic maps of Georgia. Each 7 1/2-ininute topographic quadrangle in the State has been assigned a six-digit number and letter designation beginning at the southwestern corner of the State. Numbers increase sequentially eastward and letters advance alphabetically northward. Quadrangles in the northern part of the State are designated by double letters; AA follows Z, and so forth. The letters "I", "O", "II", and "OO" are not used. Wells inventoried in each quadrangle are numbered consecutively, beginning with 01 . Thus, the fourth well scheduled in the 11AA quadrangle is designated $11 \mathrm{AA} 04$. 


\section{PRECIPITATION}

Recharge to the ground-water system in Georgia is derived almost entirely from precipitation. Based on records for 1941-70, annual precipitation averaged 50 inches (in.) statewide, and ranged from 44 in. in the east-central part to about 76 in. in the northeastern corner (fig. 1) (Carter and Stiles, 1983). Of the total annual precipitation, about 88 percent is discharged to streams or is lost to evapotranspiration, and about 12 percent enters the ground-water system as recharge (Carter and Stiles, 1983).

Monthly mean precipitation data furnished by the U.S. National Oceanic and Atmospheric Administration (1990) are shown graphically for 10 precipitation stations (figs. 2-11). For each station, monthly precipitation was compared to the 30-year (yr) (1951-80) average (normal) for the station. Cumulative departure curves are a method often used to illustrate surplus or deficit amounts of precipitation over a designated period of time. The curves used in this report were obtained by adding successive monthly values of precipitation departures from normal. For example, if precipitation in January was 2 in. above normal and in February was 1 in. below normal, the cumulative departure would be $(+2)+(-1)=+1$ in. Thus, the annual cumulative departure through December would represent the sum of all monthly deficits or surpluses during the year. Similarly, the 10-yr cumulative departure at the end of December would represent the sum of all monthly deficits or surpluses for the previous 119 months. For each of the precipitation stations, the lower graph shows the cumulative departure from normal precipitation for the period 1981-90; the upper graph shows the monthly departure and cumulative departure for 1990.

At the end of the year, the cumulative departures of precipitation for 1990 were above normal at the Athens (+2.6 in., fig. 2), Atlanta (+9.0 in., fig. 3), and Rome (+8.6 in., fig. 4) National Weather Service stations. The cumulative departures at the end of 1990 were below normal at the National Weather Service stations at Albany (-6.5 in., fig. 5), Augusta (-2.5 in., fig. 6), Clayton (-2.4 in., fig. 7), Cleveland (-1.0 in., fig. 8), Columbus (-9.6 in., fig. 9), Macon (-9.0 in., fig. 10), and Savannah (-6.6 in., fig. 11).

For the 10-yr period 1981-90, the cumulative departures of precipitation were above normal at the Atlanta (+22.3 in., fig. 3), Albany (+17.0 in., fig. 5), and Augusta (+6.0 in., fig. 6) stations. During the same period, the cumulative departures were below normal at the Athens (-63.2 in., fig. 2), Rome (-10.3 in., fig. 4), Clayton (-71.7 in., fig. 7), Cleveland (-58.7 in., fig. 8), Columbus (-48.0 in., fig. 9), Macon (-13.1 in., fig. 10), and Savannah (-20.9 in., fig. 11) stations. 


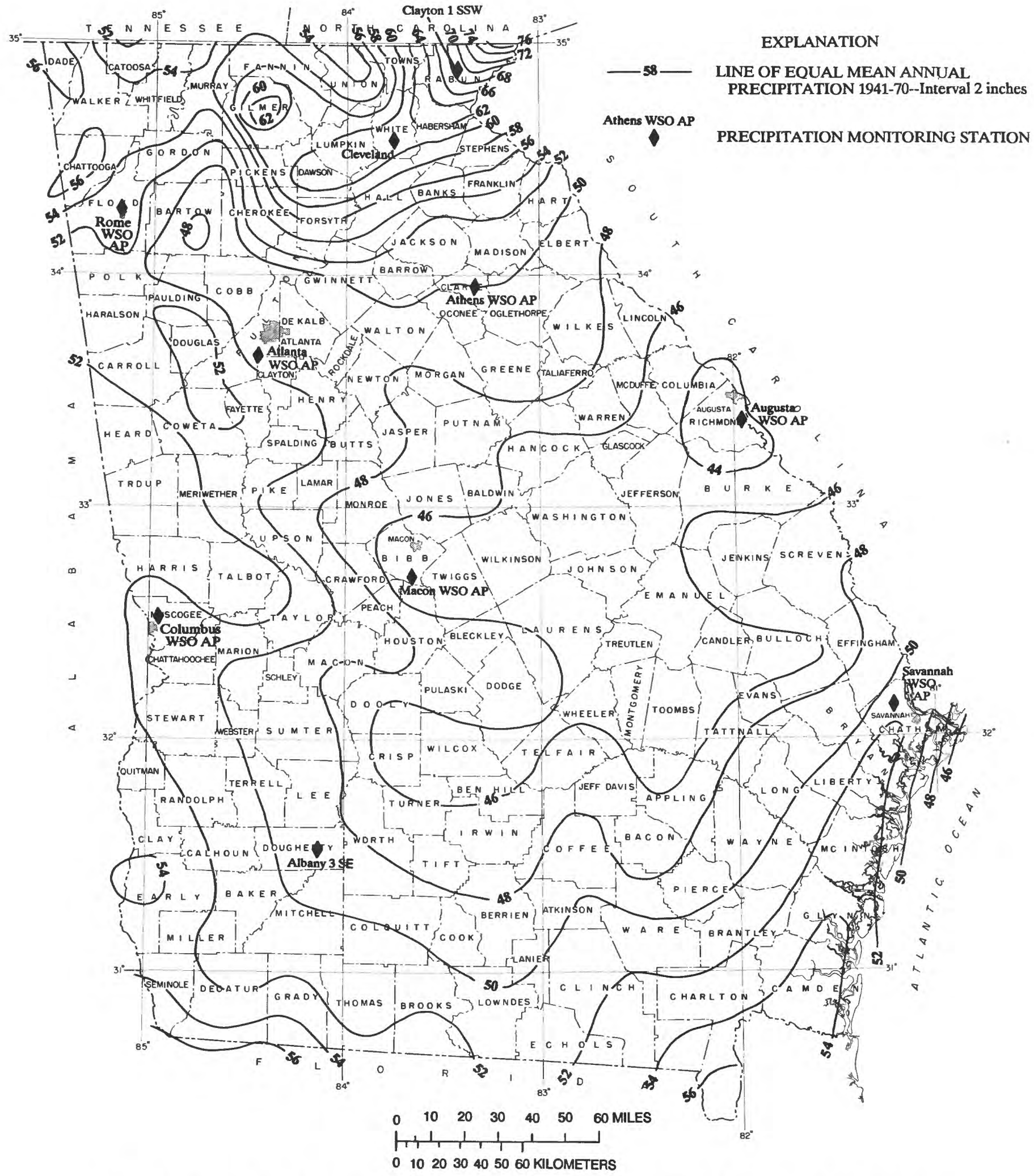

Figure 1.--Locations of precipitation-monitoring stations and mean annual precipitation in Georgia, 1941-70. Modified from Carter and Stiles (1983). 

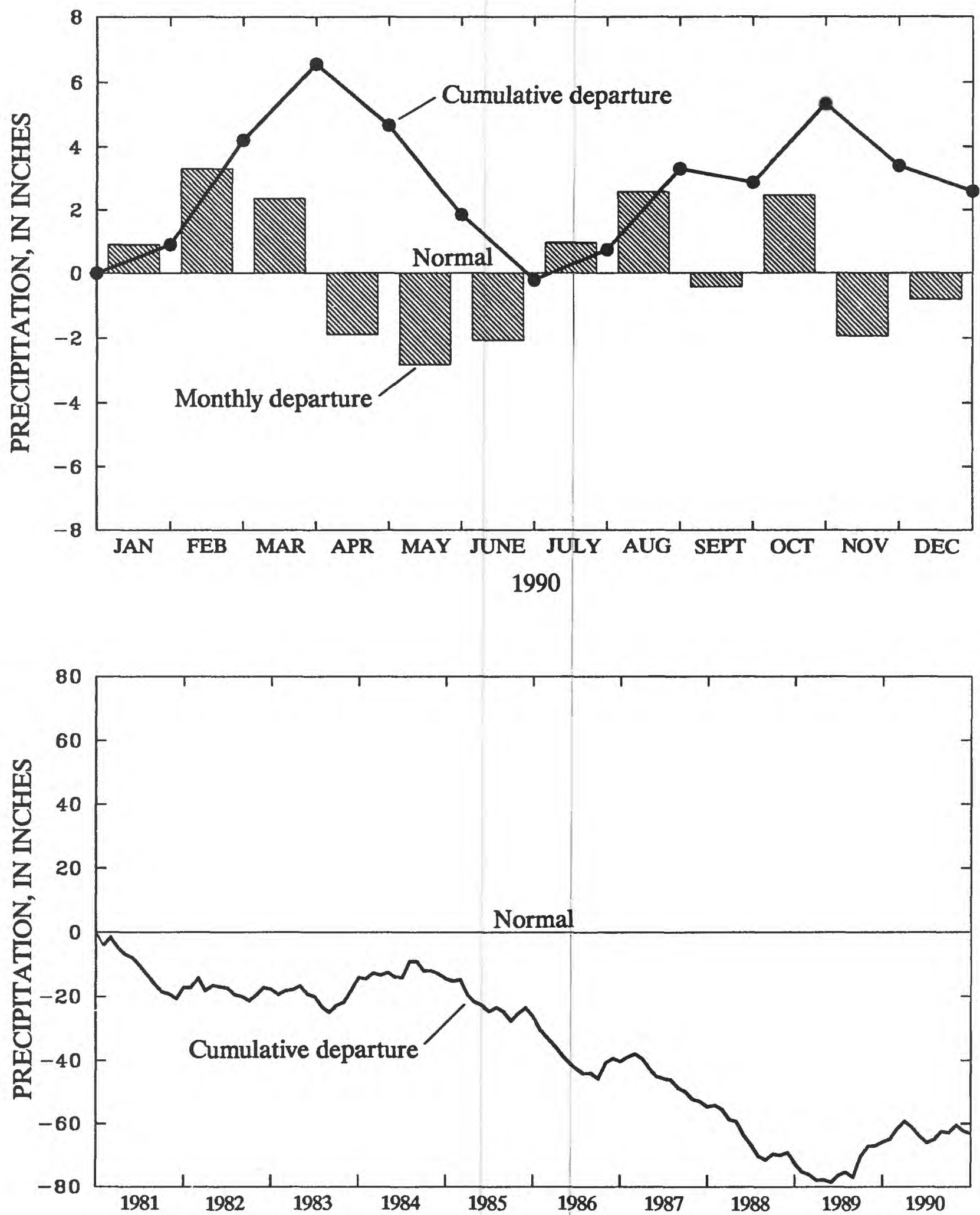

Figure 2.--Precipitation departure from normal for National Weather Service station at Athens airport, Clarke County. 

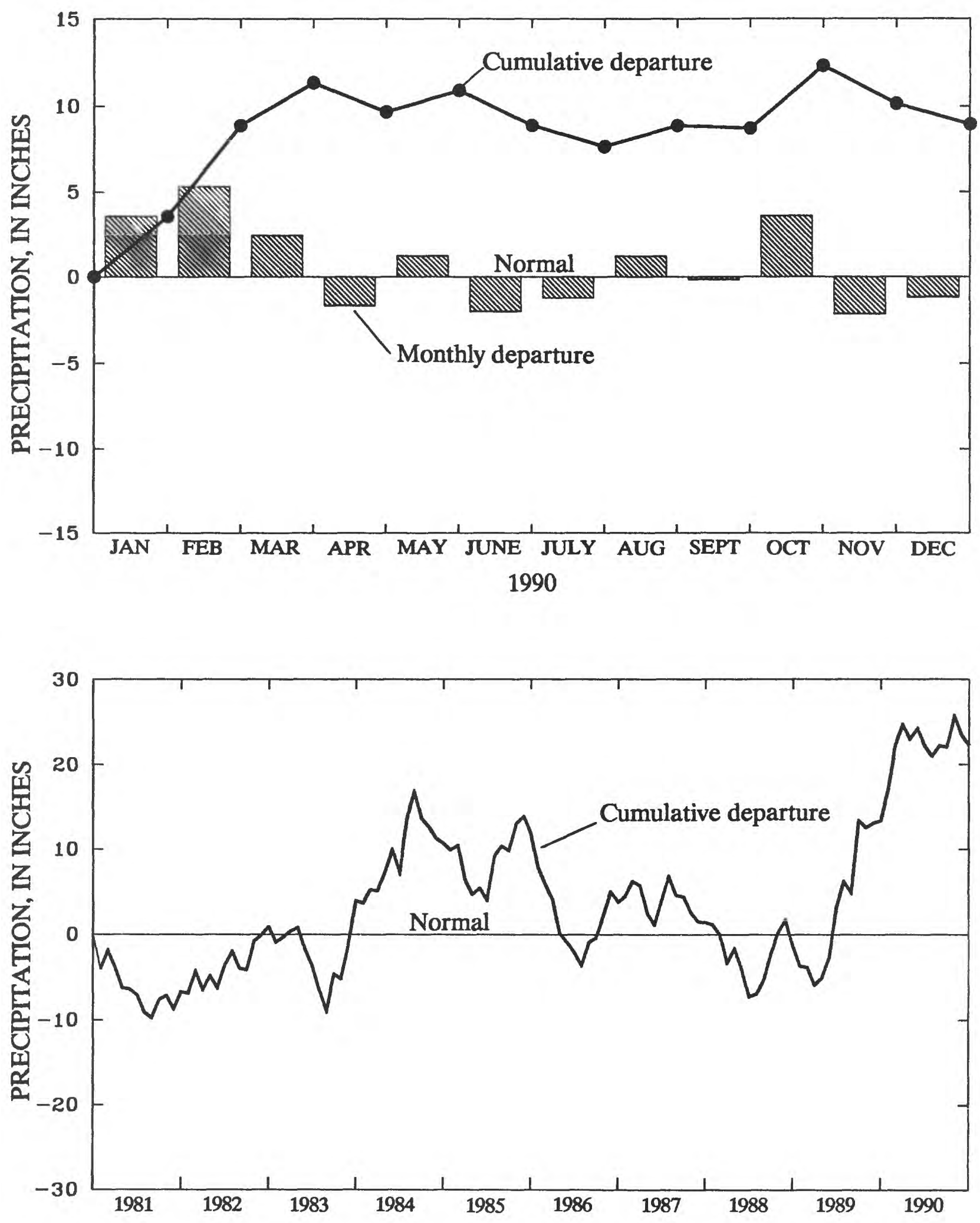

Figure 3.--Precipitation departure from normal for National Weather Service station at Atlanta airport, Fulton County. 

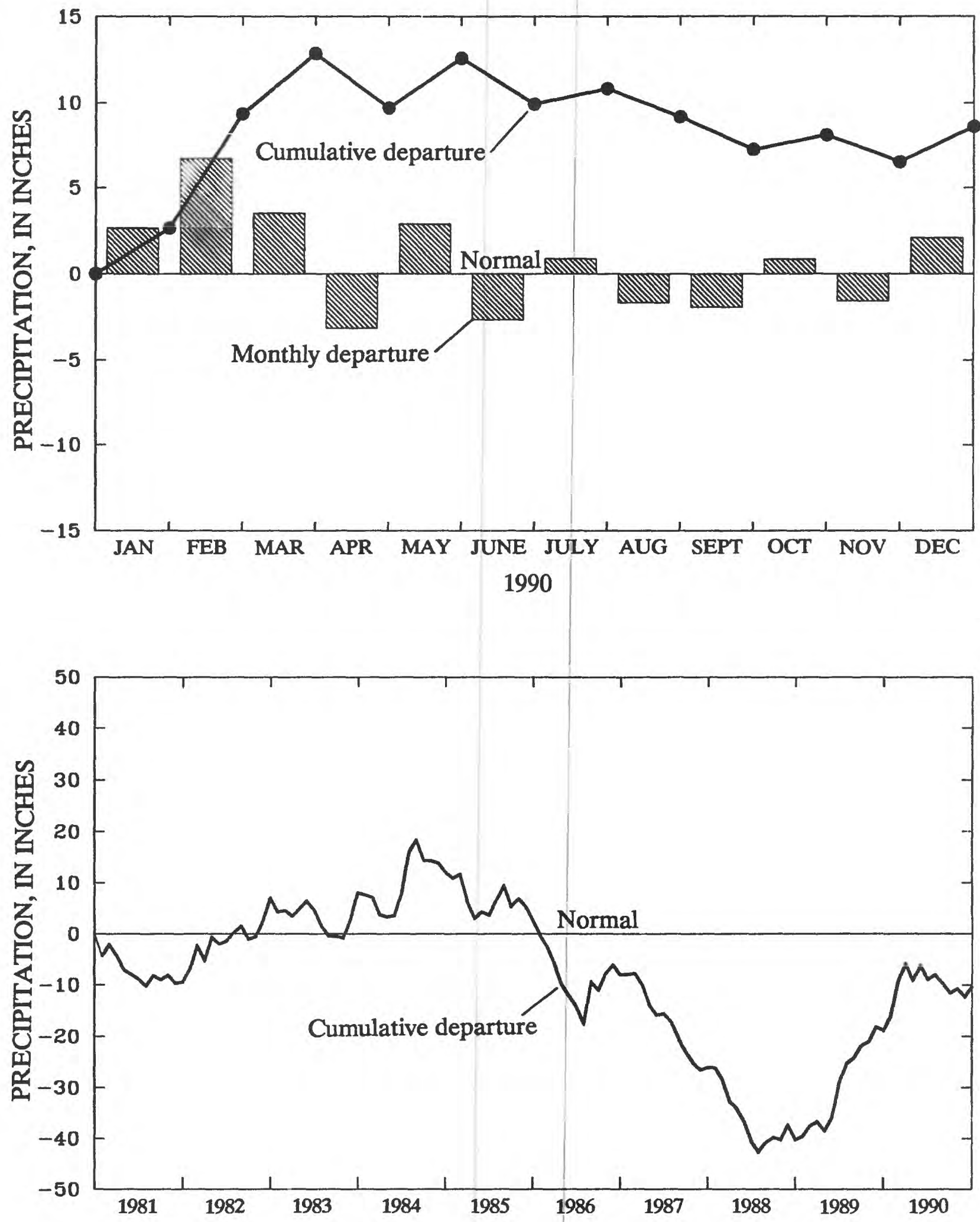

Figure 4.--Precipitation departure from normal for National Weather Service station at Rome, Floyd County. 

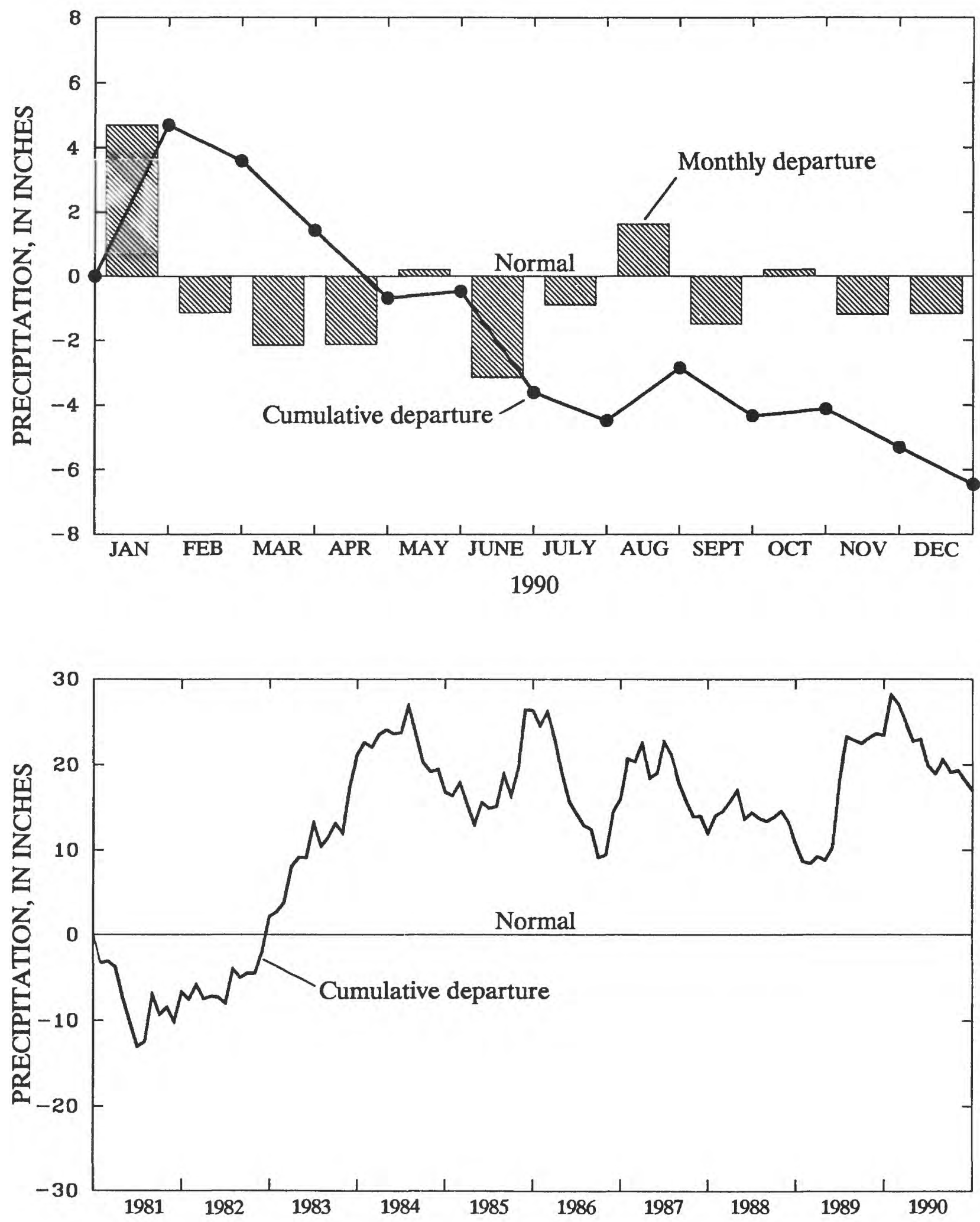

Figure 5.--Precipitation departure from normal for National Weather Service station at Albany $3 \mathrm{SE}$, Dougherty County. 

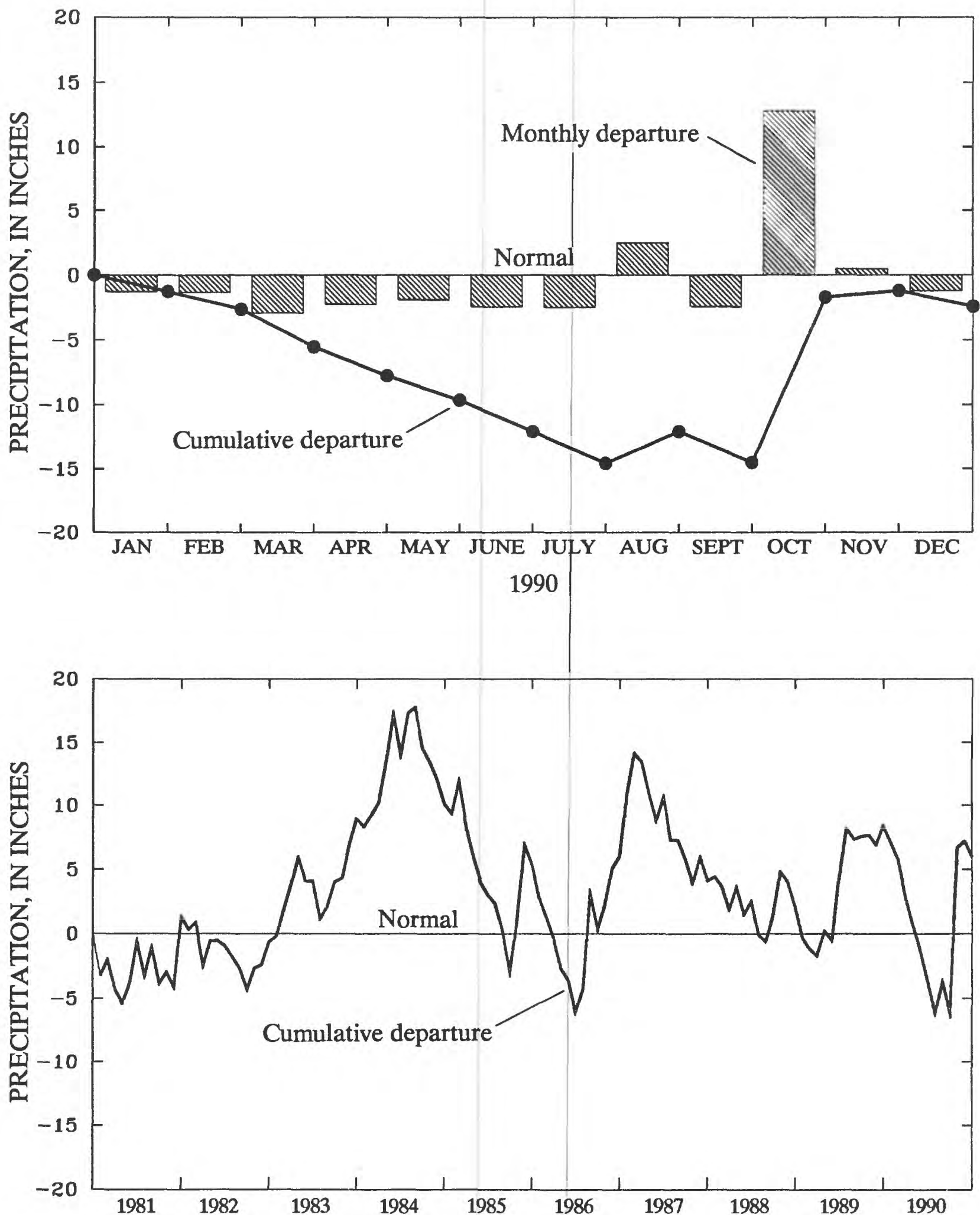

Figure 6.--Precipitation departure from normal for National Weather Service station at Augusta airport, Richmond County. 


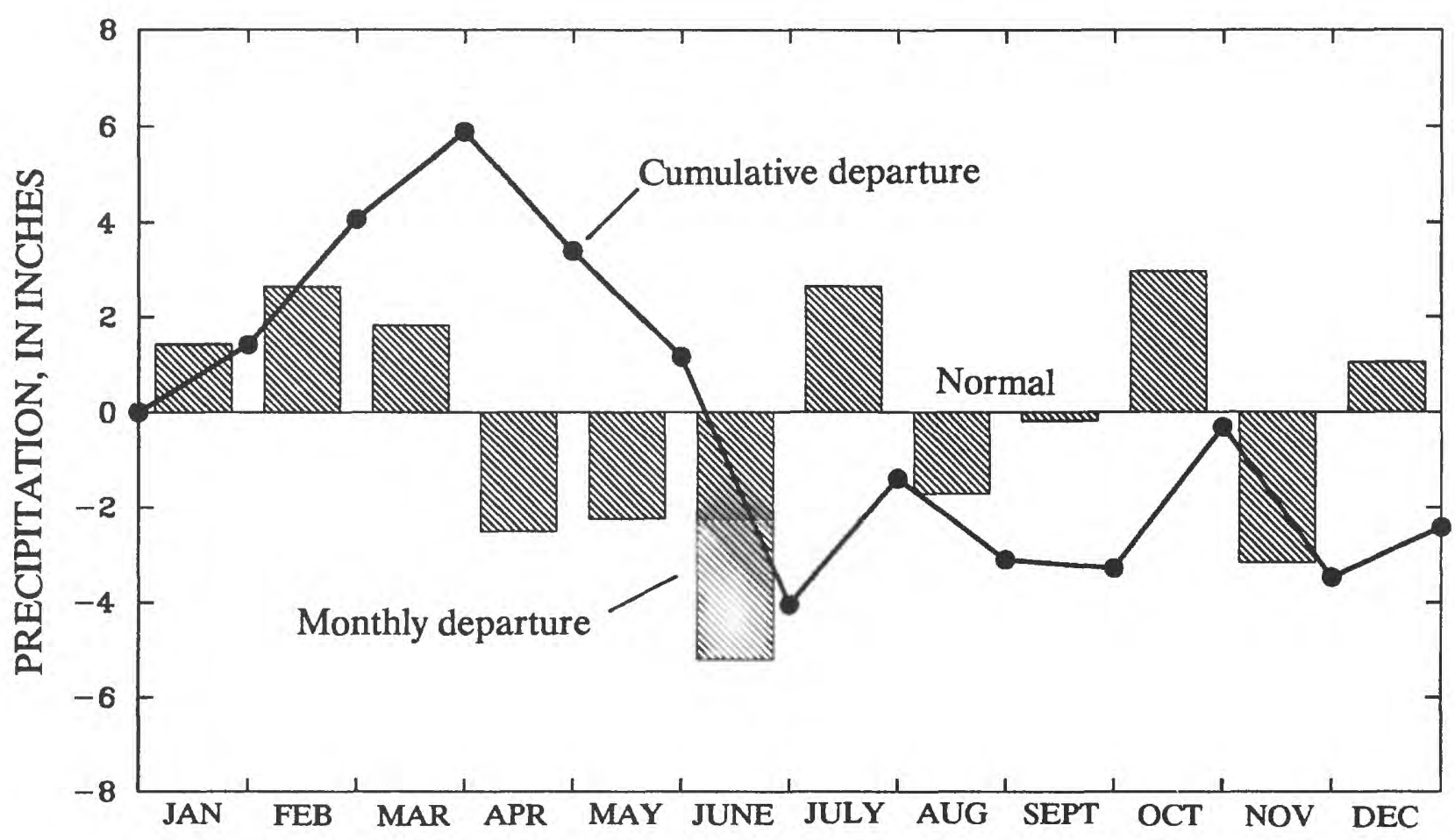

1990

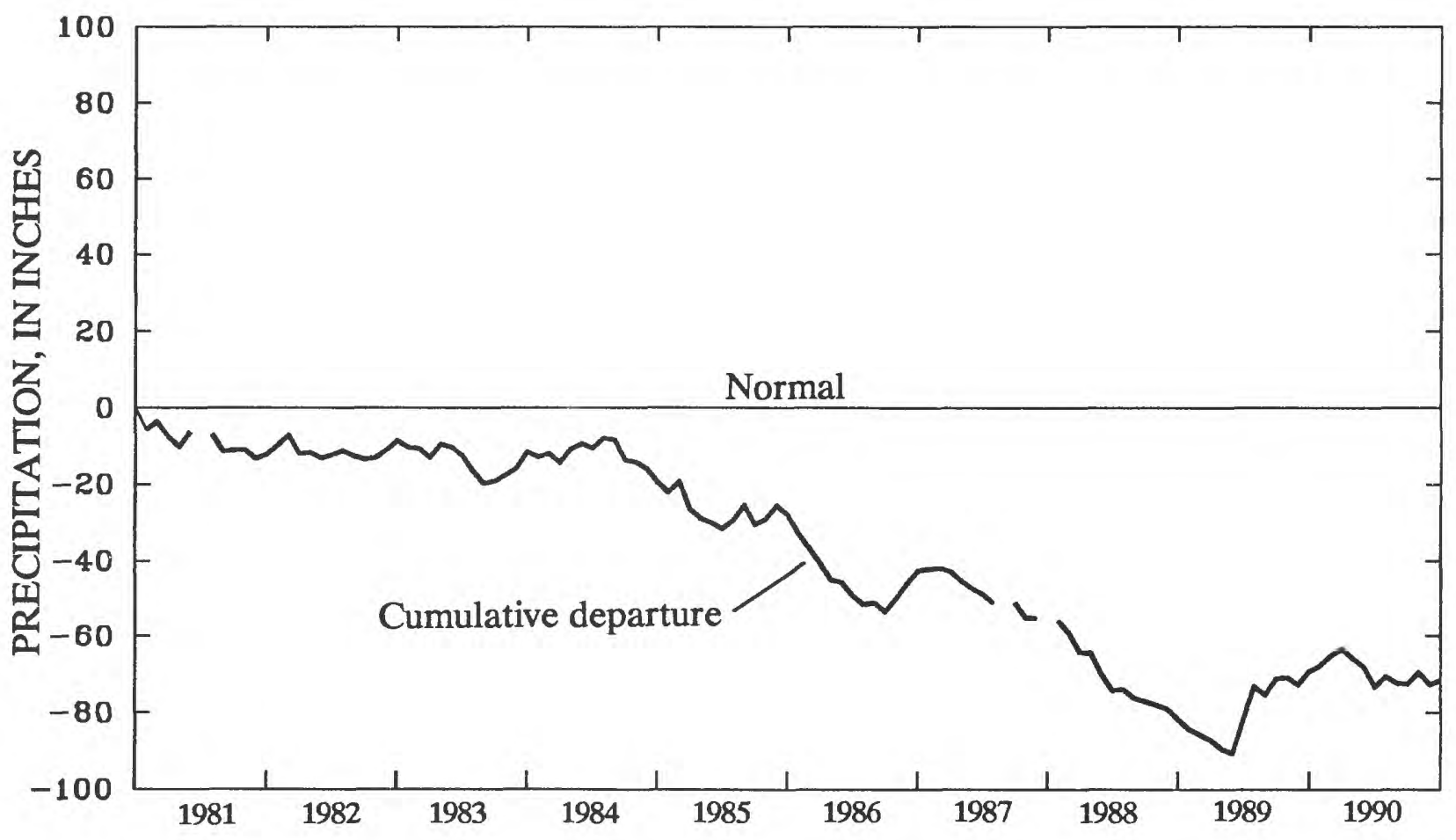

Figure 7.--Precipitation departure from normal for National Weather Service station at Clayton 1 SSW, Rabun County. 

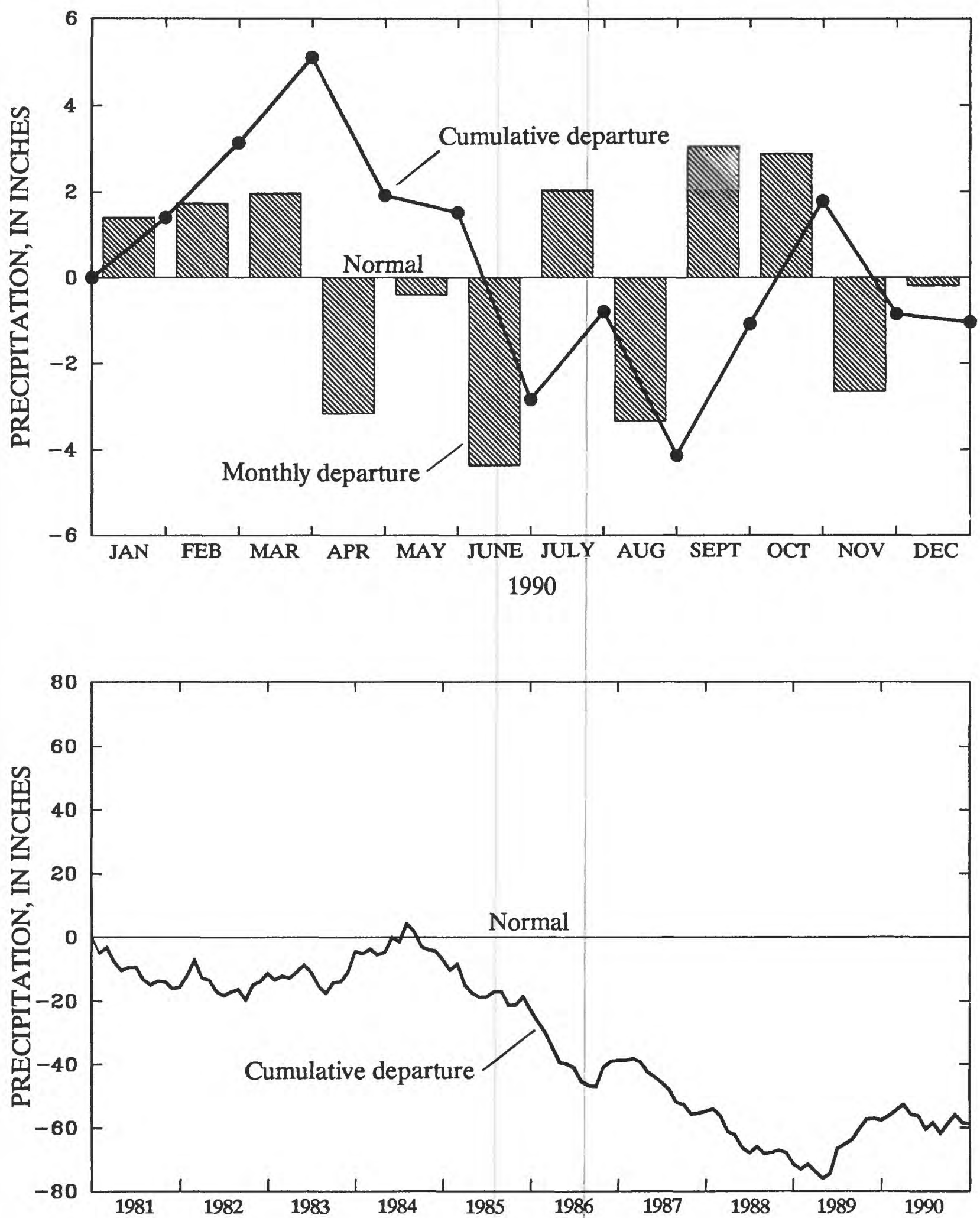

Figure 8.--Precipitation departure from normal for National Weather Service station at Cleveland, White County. 

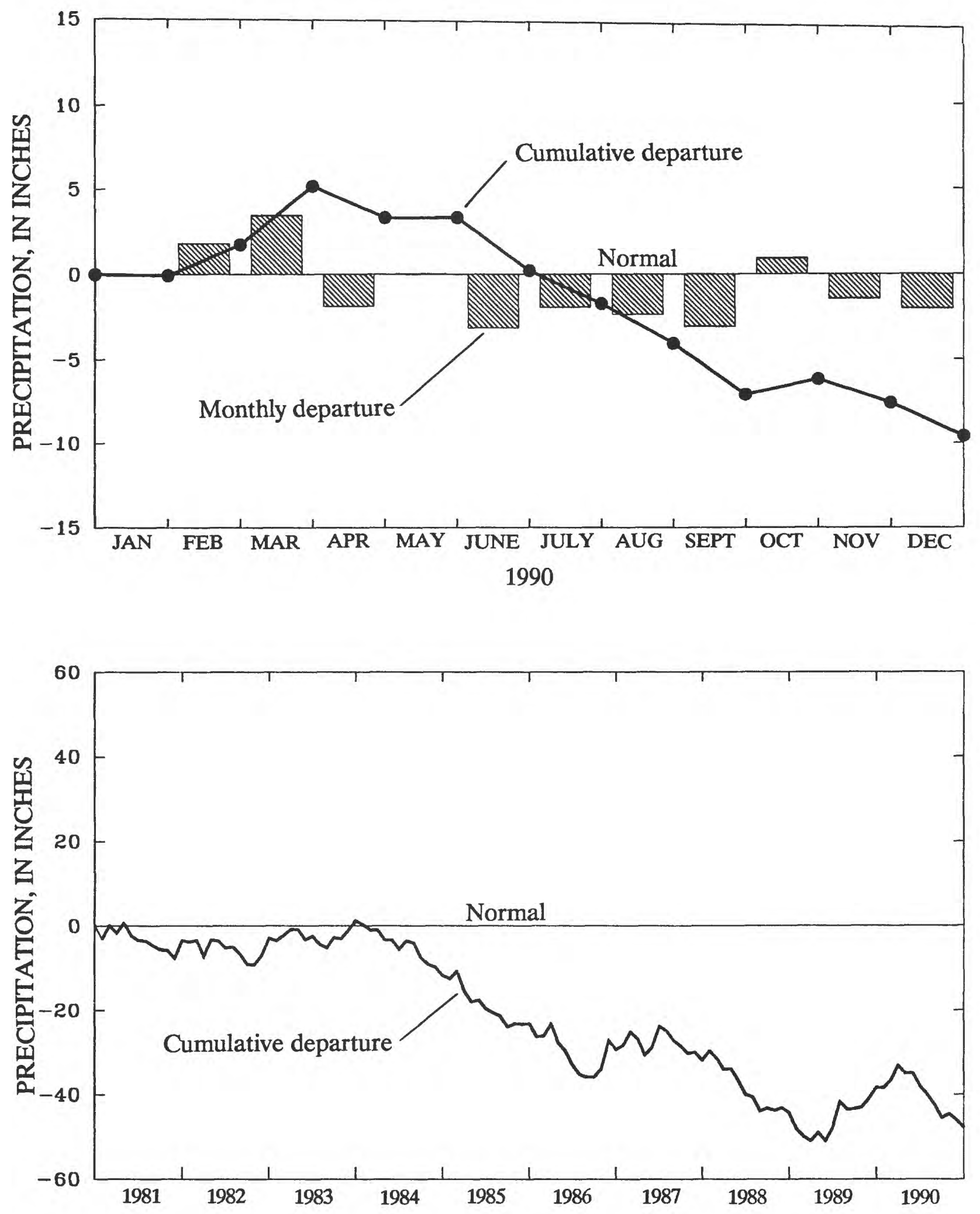

Figure 9.--Precipitation departure from normal for National Weather Service station at Columbus airport, Muscogee County. 

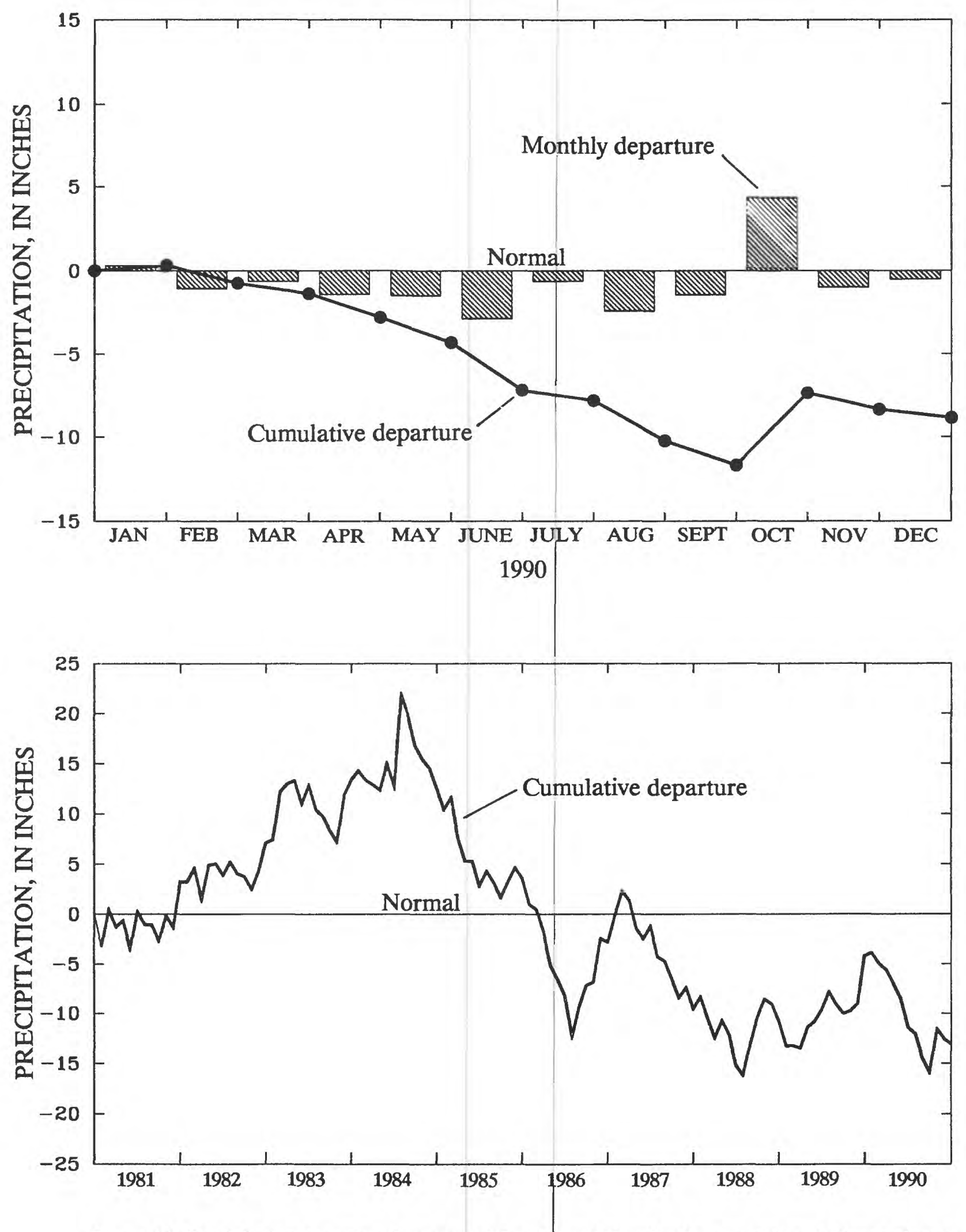

Figure 10.--Precipitation departure from normal for National Weather Service station at Macon airport, Bibb County. 

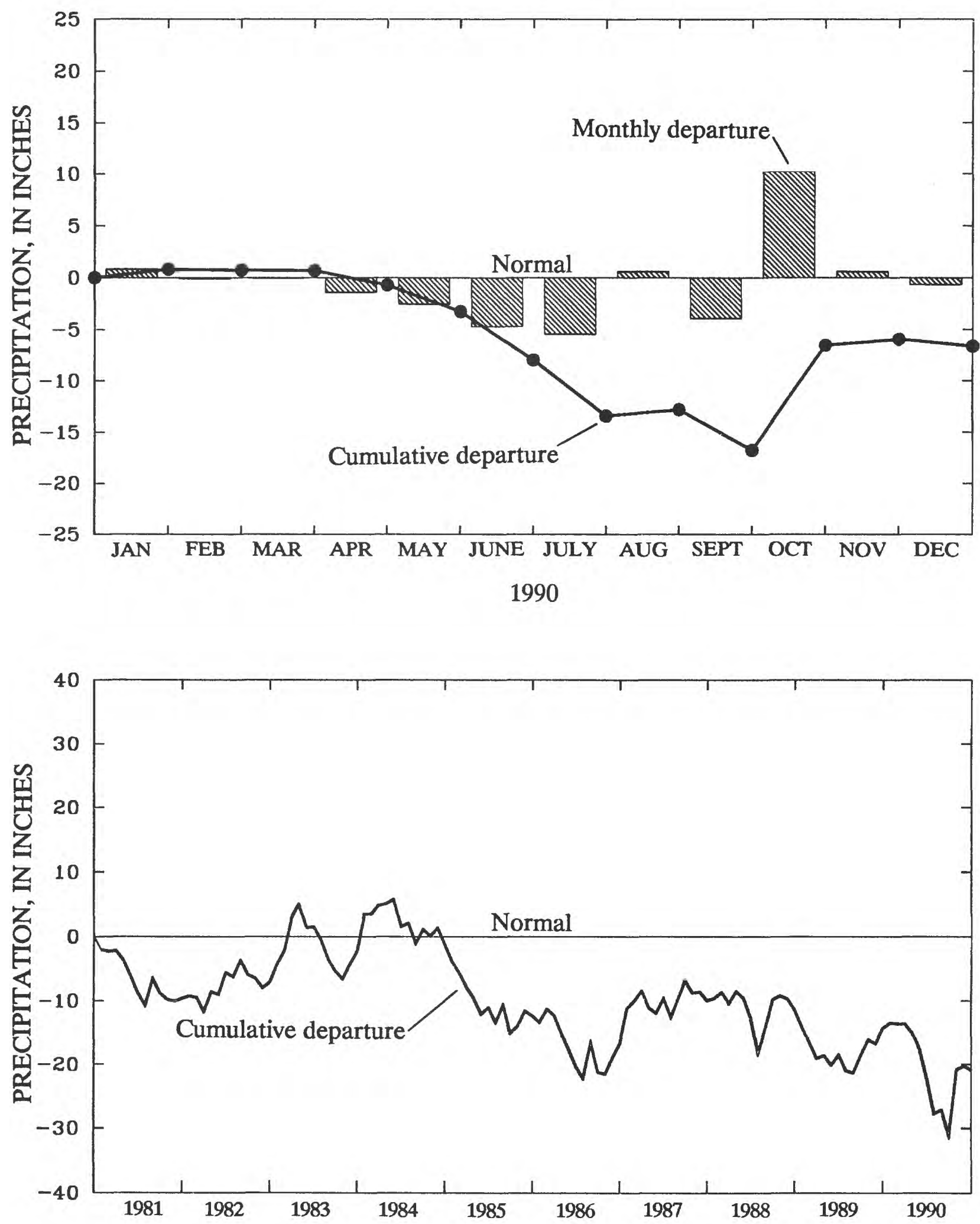

Figure 11.--Precipitation departure from normal for National Weather Service station at Savannah airport, Chatham County. 


\section{GROUND-WATER RESOURCES}

Differing geologic features and landforms of the physiographic provinces of Georgia cause substantial differences in ground-water conditions from one part of the State to another. These features affect the quantity and quality of the ground water throughout the State (fig. 12, table 1).

Surficial aquifers are present in each of the physiographic provinces. These aquifers usually are under water-table conditions, and are used for domestic and stock supplies in most areas of Georgia. In the Piedmont, Blue Ridge, and Valley and Ridge provinces, the surficial aquifers occur in the regolith, which consists of soil, saprolite, stream alluvium, colluvium, and other surficial deposits. In the Coastal Plain province, the surficial aquifers consist of intermixed layers of sand, clay, and limestone. In the coastal area, the surficial aquifers locally may be under semi-confined conditions.

In the Piedmont and Blue Ridge provinces, ground water occurs in fractures, other secondary openings, and along foliation or other layers in the crystalline bedrock. Rocks in these provinces are complex and consist of metamorphic and igneous rocks. In the Valley and Ridge province, ground water occurs in both primary and secondary openings in folded and faulted sedimentary and meta-sedimentary rocks.

The most productive aquifers in Georgia are in the Coastal Plain province in the southern part of the State. The Coastal Plain is underlain by alternating layers of sand, clay, and limestone that dip and thicken to the southeast. In the Coastal Plain, aquifers generally are confined, except near their northern limits where they are exposed or are near land surface. The aquifers of the Coastal Plain include surficial aquifers, the upper Brunswick aquifer, the lower Brunswick aquifer, the Floridan aquifer system, the Claiborne aquifer, the Clayton aquifer, and the Cretaceous aquifers and aquifer systems (fig. 12). 

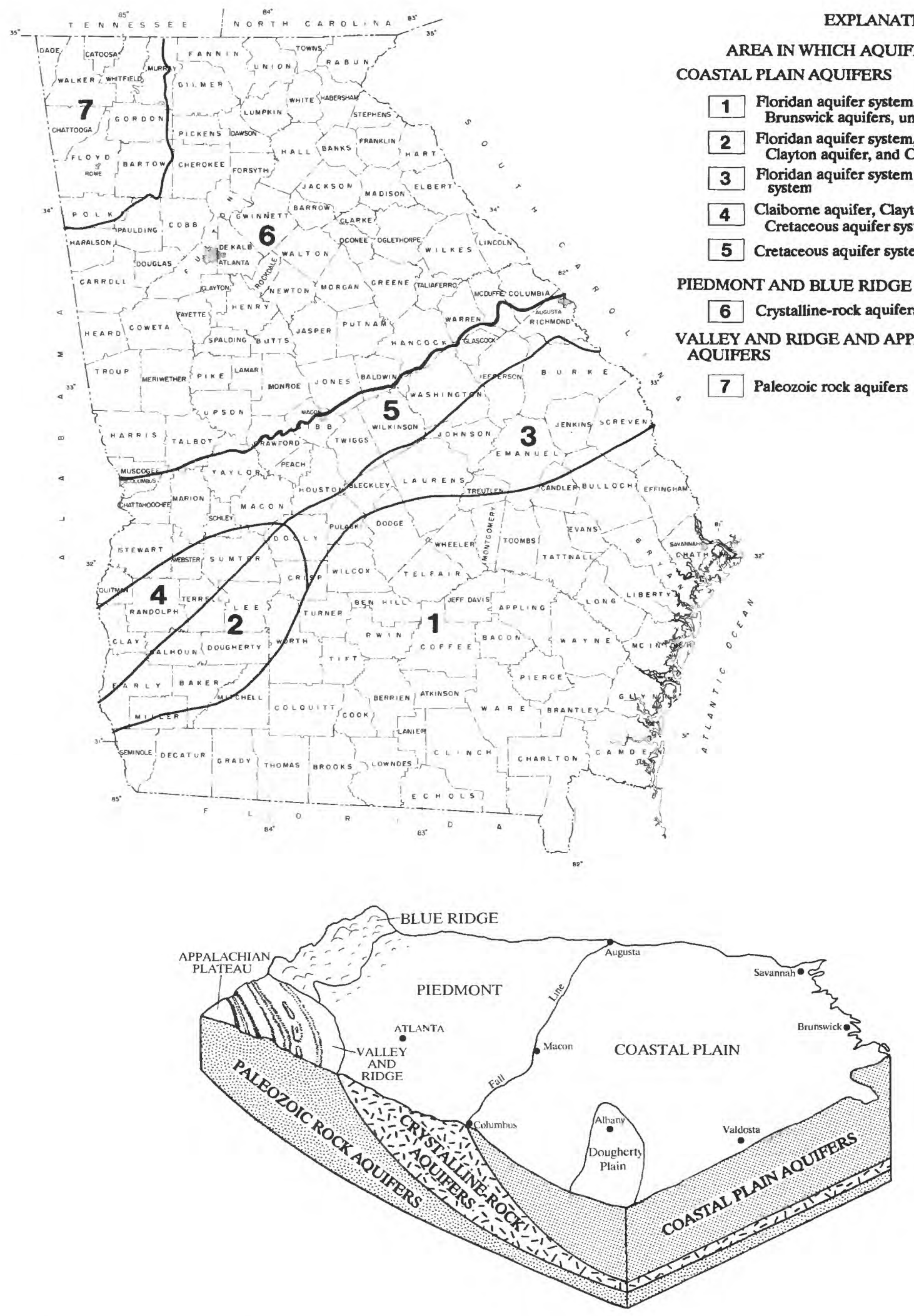

Figure 12.--Areas of utilization of major aquifers and block diagram showing major aquifers and physiographic provinces of Georgia. 
Table 1.--Aquifer and well characteristics in Geongia

[Modified from Clarke and Pierce, 1984; ft, feet; gal/min, gallons per minute]

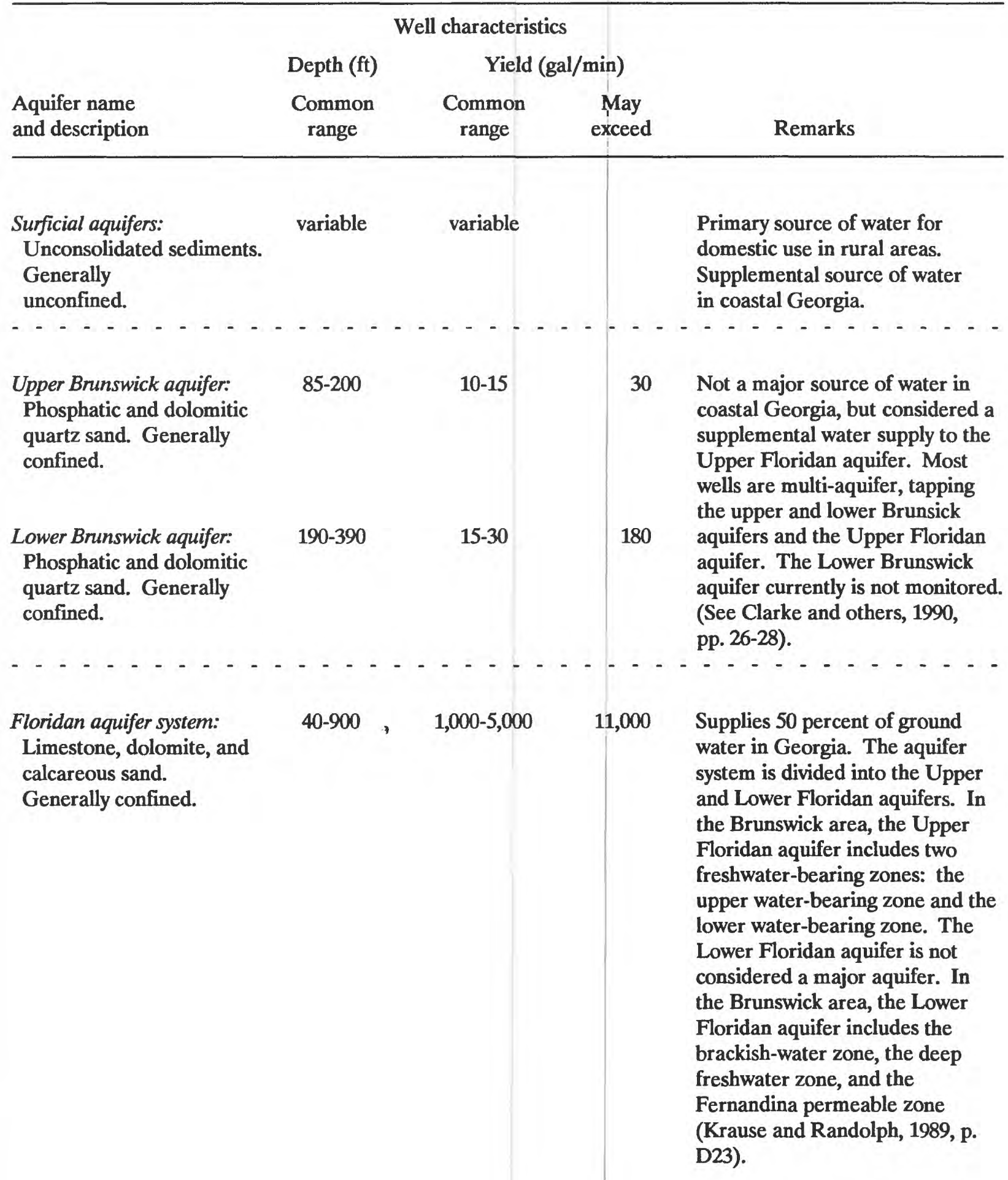


Table 1.--Aquifer and well characteristics in Georgia--Continued

[Modified from Clarke and Pierce, 1984; ft, feet; gal/min, gallons per minute]

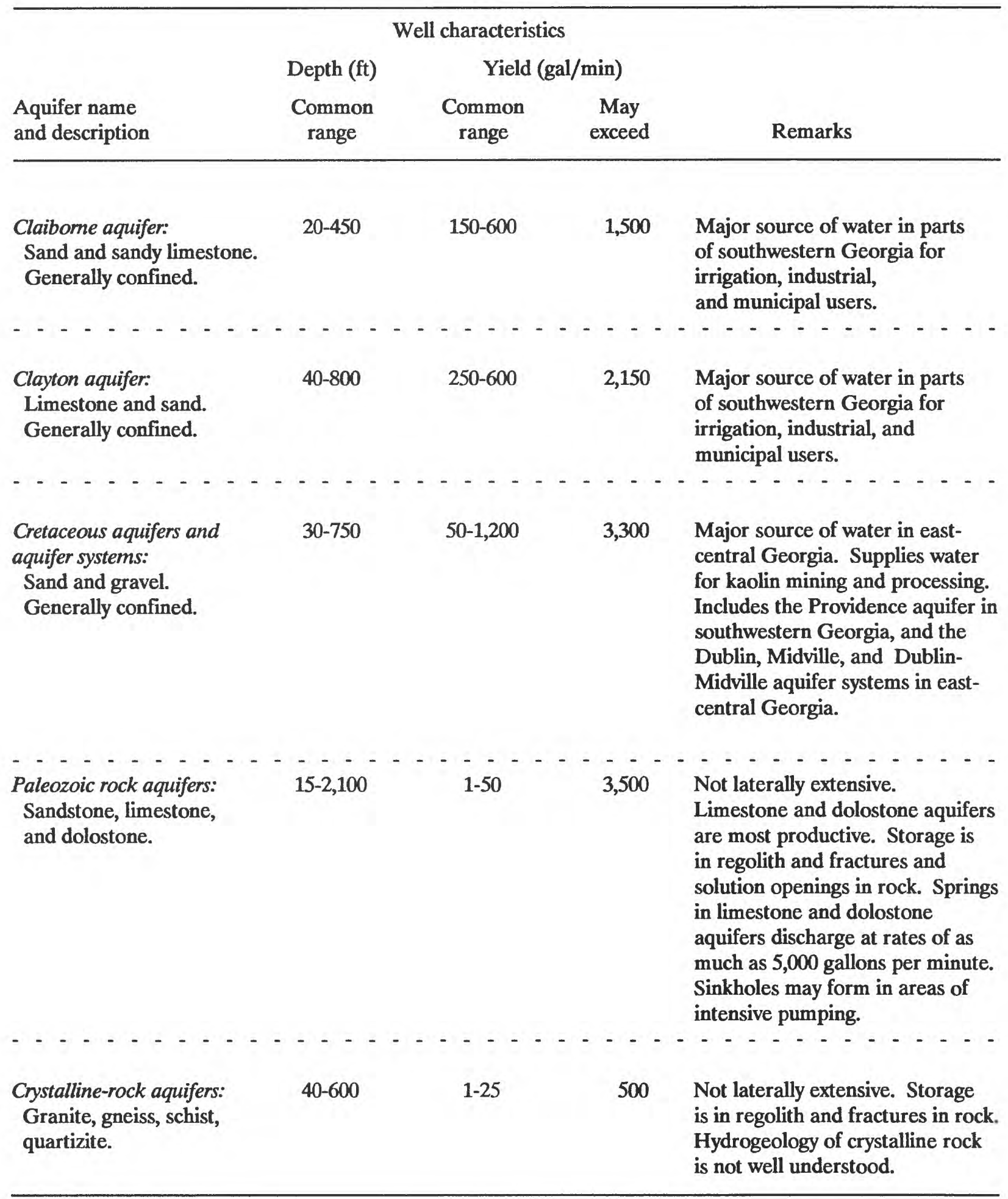




\section{GROUND-WATER LEVELS}

Fluctuations and long-term trends in ground-water levels occur as a result of variations in recharge and discharge. Recharge varies in response to precipitation and surface-water infiltration into the aquifer. Discharge occurs as natural flow from the aquifer to streams and springs, as evapotranspiration from shallow water-table aquifers, and as withdrawal from wells.

Water-level fluctuations and trends were monitored during 1990 in a network of 140 wells tapping the surficial and upper Brunswick aquifers, the Floridan aquifer system, the Claiborne and Clayton aquifers, the Cretaceous aquifer systems, the Paleozoic rock aquifers, and the crystalline-rock aquifers. Of the 140 network wells that were monitored continuously during 1990, daily mean water levels are shown in hydrographs for 76 of the wells (fig. 13, table 2). Water-level fluctuations and trends in these 76 wells are considered to be representative of ground-water conditions throughout the State. Discussions of the ground-water conditions shown in these hydrographs were grouped by aquifer and subdivided into areas and subareas in which wells had similar water-level changes in response to variations in recharge and discharge.

For each well, daily mean water levels are shown in hydrographs for 1990, and monthly and annual mean water levels are shown in long-term hydrographs that include the period of record since monitoring began at each well. A summary of monthly and annual mean water-level statistics for 1990 is included with each hydrograph. The text accompanying each section discusses (1) the 1990 annual mean water level for each well compared to the 1989 annual mean water level (from Peck and others, 1990), (2) the most recent water-level trend based on the long-term hydrographs, and (3) the occurrence of record-low or -high water levels in 1990. In this report, a record water level refers to the lowest or highest daily mean water level for the period of record in a particular well. Thus, any individual water-level measurement on a given day may be lower or higher than the record water level mentioned in the text, the minimum or maximum value in the statistics, or the daily mean water level shown on the hydrograph. In discussions of differences in annual, monthly, or daily mean water levels, the terms "slightly" and "about the same" are used for differences less than or equal to $0.1 \mathrm{ft}$.

Continuous records from the 76 wells indicate that annual mean ground-water levels during 1990 were from about $11.4 \mathrm{ft}$ lower to about $3.2 \mathrm{ft}$ higher than in 1989. When compared to $1989 \mathrm{data}$, the annual mean water level during 1990 was higher in 24 wells and lower in 52 wells. Record-high water levels were recorded in five wells tapping the Claiborne and crystalline-rock aquifers that were from about 0.4 to about $5.0 \mathrm{ft}$ higher than the previous highs. Record-low daily mean water levels were measured during 1990 in 33 wells in the Coastal Plain that were from slightly lower to about $7.8 \mathrm{ft}$ lower than the previous record lows. The record lows were recorded in the surficial aquifer during October in Wayne County and July near Brunswick; the upper Brunswick aquifer during October in Wayne County; the Upper and Lower Floridan aquifers during July to December throughout the Coastal Plain; the Claiborne aquifer during September in Crisp County; the Clayton aquifer during December in southern Dougherty County; a Cretaceous aquifer during December in Chattahoochee County; and the Dublin, Midville, and Dublin-Midville aquifer systems during October to November throughout the northeastern Coastal Plain. 


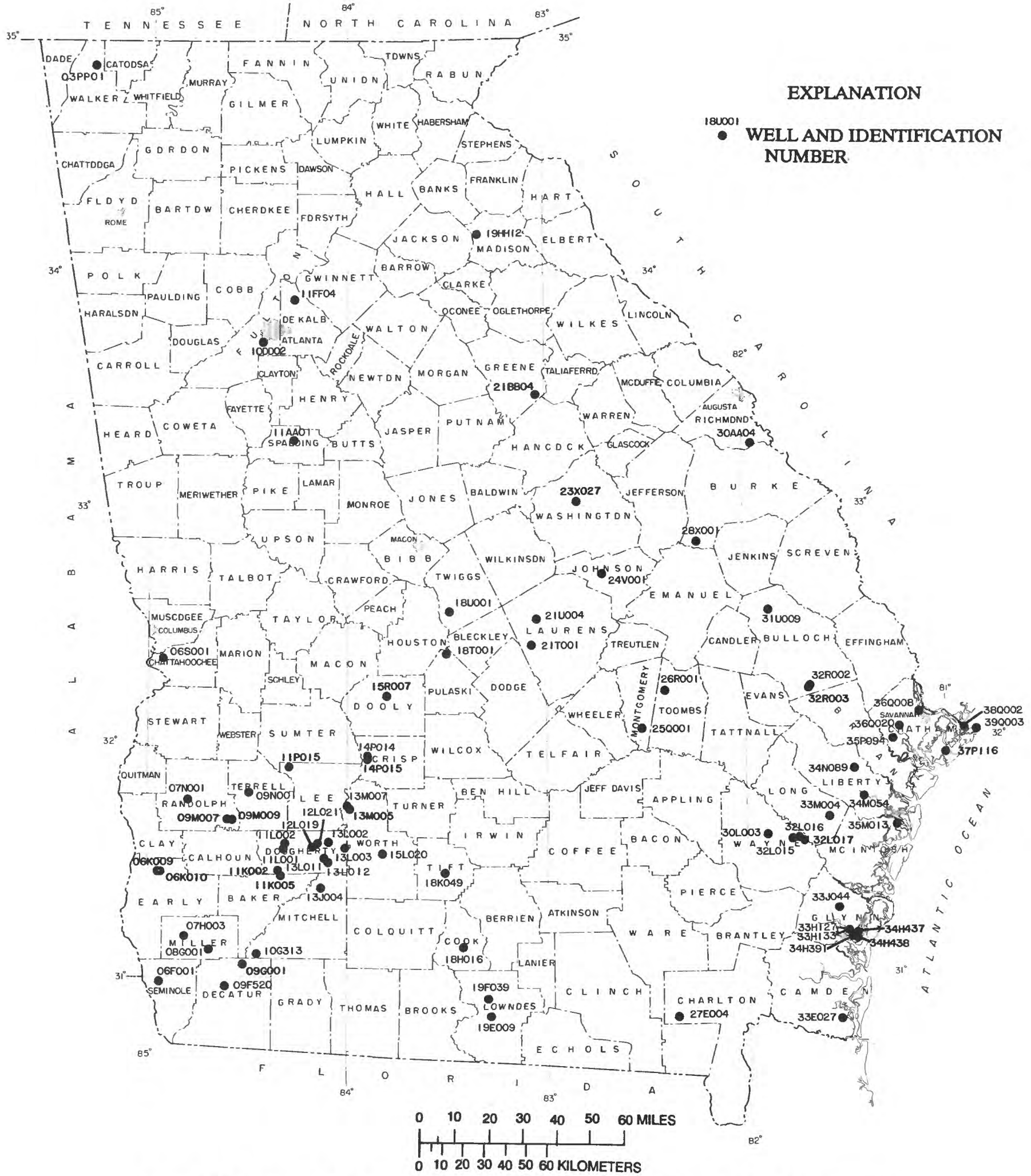

Figure 13.--Locations of observation wells for which hydrographs are included in this report. 
Table 2.--Observation wells for which water-level hydrographs are included in this report

\begin{tabular}{|c|c|c|c|}
\hline County & Aquifer & $\begin{array}{l}\text { Well } \\
\text { number }\end{array}$ & Well name \\
\hline Bulloch & Upper Floridan & 32R002 & Bulloch South test well 1 \\
\hline Bulloch & Surficial & $32 \mathrm{R} 003$ & Bulloch South test well 2 \\
\hline Bulloch & Upper Brunswick & 31U009 & Hopeulikit test well 2 \\
\hline Burke & Midville aquifer system & $28 \times 001$ & Midville Experimental Station \\
\hline Camden & Upper Floridan & $33 \mathrm{E} 027$ & Kings Bay \\
\hline Charlton & Upper Floridan & $27 \mathrm{E} 004$ & Test well $\mathrm{OK} 9$ \\
\hline Chatham & Surficial & $35 \mathrm{P} 094$ & UGA \\
\hline Chatham & Upper Floridan & $36 \mathrm{Q} 008$ & Layne-Atlantic \\
\hline Chatham & Upper Floridan & 360020 & Morrison \\
\hline Chatham & Surficial & 37P116 & Skidaway Institute test well 4 \\
\hline Chatham & Upper Floridan & 380002 & Pilot House \\
\hline Chatham & Upper Floridan & 390003 & Test well 7, point 3 \\
\hline Chattahoochee & Cretaceous aquifer system & $06 \mathrm{~S} 001$ & Fort Benning \\
\hline Cook & Upper Floridan & $18 \mathrm{H} 016$ & Adel \\
\hline Crisp & Clayton & $14 \mathrm{P} 014$ & $\begin{array}{l}\text { Georgia Veterans Memorial } \\
\text { State Park test well } 1\end{array}$ \\
\hline Crisp & Claiborne & $14 \mathrm{P} 015$ & $\begin{array}{l}\text { Georgia Veterans Memorial } \\
\text { State Park test well } 2\end{array}$ \\
\hline Decatur & Upper Floridan & 09F520 & Bolton \\
\hline Decatur & Claiborne & 09G001 & DP-4 \\
\hline DeKalb & Crystalline rock & 11FF04 & GAR, test well 5 \\
\hline Dooly & Claiborne & 15R007 & Pinehurst-Horne \\
\hline Dougherty & Providence & $12 \mathrm{LO} 21$ & Test well 10 \\
\hline Dougherty & Claiborne & $11 \mathrm{~K} 002$ & Test well 11 \\
\hline Dougherty & Clayton & $11 \mathrm{~K} 005$ & Test well 12 \\
\hline Dougherty & Clayton & $11 L 002$ & Albany Nursery \\
\hline Dougherty & Clayton & 13L002 & Turner City \\
\hline Dougherty & Claiborne & 11L001 & Test well 4 \\
\hline Dougherty & Claiborne & 12L019 & Test well 5 \\
\hline Dougherty & Claiborne & 13L011 & Test well 2 \\
\hline Dougherty & Upper Floridan & 13L003 & Albany-Dougherty County \\
\hline Dougherty & Upper Floridan & 13L012 & Test well 3 \\
\hline Early & Clayton & $06 \mathrm{~K} 009$ & Kolomoki State Park test well 1 \\
\hline Early & Claiborne & $06 \mathrm{~K} 010$ & Kolomoki State Park test well 2 \\
\hline Fulton & Crystalline rock & 10DD02 & Fort McPherson \\
\hline Glynn & Upper Floridan & $33 \mathrm{H} 127$ & Test well 3 \\
\hline Glynn & Upper Floridan & $33 H 133$ & Test well 6 \\
\hline Glynn & Lower Floridan & 33J044 & Test well 27 \\
\hline Glynn & Lower Floridan & $34 \mathrm{H} 391$ & Test well 16 \\
\hline Glynn & Upper Brunswick & $34 \mathrm{H} 437$ & Coffin Park test well 2 \\
\hline Glynn & Surficial & $34 \mathrm{H} 438$ & Coffin Park test well 3 \\
\hline
\end{tabular}


Table 2.--Observation wells for which water-level hydrographs are included in this report-Continued

\begin{tabular}{|c|c|c|c|}
\hline County & Aquifer & $\begin{array}{l}\text { Well } \\
\text { number }\end{array}$ & Well name \\
\hline Greene & Crystalline rock & 21BB04 & Veazey \\
\hline Johnson & Midville aquifer system & 24V001 & Test well 1 \\
\hline Laurens & Upper Floridan & $21 \mathrm{~T} 001$ & Hogan \\
\hline Laurens & Midville aquifer system & $21 \mathrm{U} 004$ & Test well 3 \\
\hline Lee & Claiborne & 11P015 & Pete Long 2 \\
\hline Liberty & Upper Floridan & $34 \mathrm{M} 054$ & Test well 2 \\
\hline Liberty & Upper Floridan & 34N089 & Test well 1 \\
\hline Long & Upper Floridan & $33 \mathrm{M} 004$ & Test well 3 \\
\hline Lowndes & Upper Floridan & 19E009 & Valdosta \\
\hline Lowndes & Upper Floridan & $19 F 039$ & Valdosta 8 \\
\hline Madison & Crystalline rock & $19 \mathrm{HH} 12$ & Meadowlake Estates \\
\hline McIntosh & Upper Floridan & $35 \mathrm{M} 013$ & Harris Neck \\
\hline Miller & Surficial & $07 \mathrm{H} 003$ & DP-3 \\
\hline Miller & Upper Floridan & 08G001 & Viercocken \\
\hline Mitchell & Upper Floridan & $10 \mathrm{G} 313$ & Meinders \\
\hline Mitchell & Upper Floridan & $13 \mathrm{~J} 004$ & Wright \\
\hline Montgomery & Upper Floridan & $25 Q 001$ & Uvalda School \\
\hline Pulaski & Midville aquifer system & $18 \mathrm{~T} 001$ & Arrowhead test well 1 \\
\hline Randolph & Clayton & $07 \mathrm{~N} 001$ & Cuthbert \\
\hline Randolph & Clayton & $09 \mathrm{M} 007$ & Martin test well 2 \\
\hline Randolph & Claiborne & $09 \mathrm{M} 007$ & Martin test well 1 \\
\hline Richmond & $\begin{array}{l}\text { Dublin-Midville aquifer } \\
\text { system }\end{array}$ & 30AA04 & McBean 2 \\
\hline Seminole & Upper Floridan & $06 \mathrm{~F} 001$ & Roddenberry Farms test well 1 \\
\hline Spalding & Surficial & 11AA01 & UGA Experiment Station \\
\hline Terrell & Clayton & $09 \mathrm{~N} 001$ & Graves School \\
\hline Tift & Upper Floridan & 18K049 & Test well 1 \\
\hline Toombs & Upper Floridan & 26R001 & Vidalia 2 \\
\hline Twiggs & Dublin aquifer system & $18 \mathrm{U} 001$ & Test well 3 \\
\hline Walker & Paleozoic rock & 03PP01 & Chickamauga Battlefield \\
\hline Washington & $\begin{array}{l}\text { Dublin-Midville aquifer } \\
\text { system }\end{array}$ & $23 \times 027$ & Sandersville 8 \\
\hline Wayne & Upper Floridan & 30L003 & Johnson \\
\hline Wayne & Upper Floridan & $32 L 015$ & Gardi test well 1 \\
\hline Wayne & Upper Brunswick & 32L016 & Gardi test well 2 \\
\hline Wayne & Surficial & $32 \mathrm{~L} 017$ & Gardi test well 3 \\
\hline Worth & Claiborne & 13M005 & DP-7 \\
\hline Worth & Surficial & 13M007 & DP-9 \\
\hline Worth & Upper Floridan & $15 \mathrm{LO20}$ & Sylvester \\
\hline
\end{tabular}




\section{Surficial Aquifers}

Water-level fluctuations and trends in surficial aquifers are monitored in 13 wells, 8 of which are summarized in this report (fig. 14). Water-level fluctuations in surficial aquifers are caused mainly by variations in precipitation, evapotranspiration, and natural drainage. Water levels in surficial aquifers generally rise rapidly during wet periods and decline slowly during dry periods. Prolonged droughts may cause water levels to decline below pump intakes in shallow wells, particularly those located on hilltops and steep slopes, resulting in temporary well failures. Usually, well yields are restored with an increase in precipitation. In some areas, the surficial aquifer is semi-confined and influenced by local pumping. 


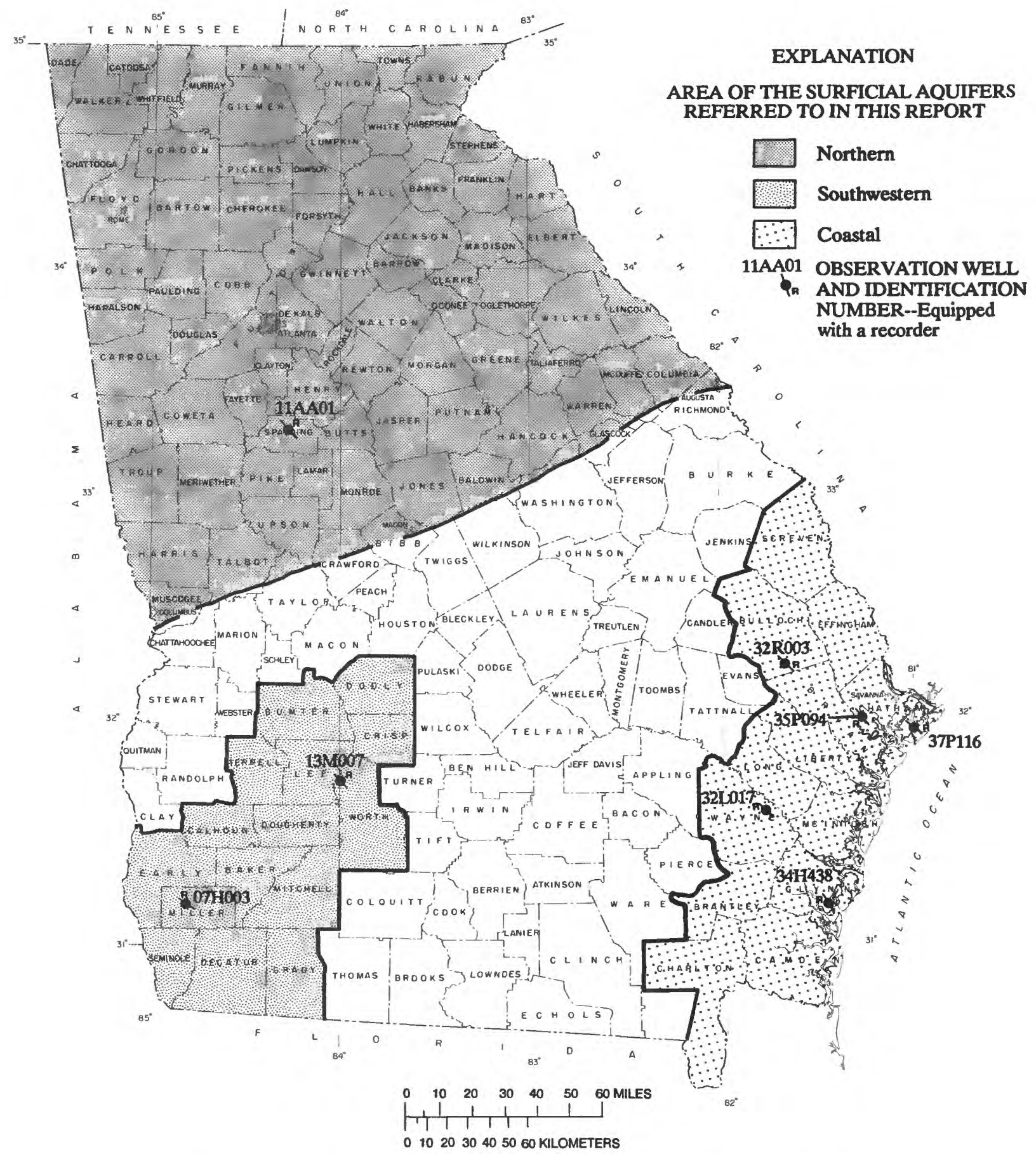

Figure 14.--Locations of observation wells completed in the surficial aquifers. 


\section{Northern area}

Water-levels in the surficial aquifers in the northern part of Georgia are monitored in two wells, and a summary of the data for one of these wells is included in this report. In this area, water levels in the surficial aquifer are affected by variations in precipitation, as illustrated by the hydrograph for well 11AA01 (fig. 15) at Griffin, Spalding County, and the precipitation graph from the National Weather Service station at Atlanta (fig. 3). The annual mean water level in well 11AA01 (fig. 15) was about $0.9 \mathrm{ft}$ higher in 1990 than in 1989, continuing a slight trend of rising water levels that began in 1988. 
331507084171801 Local number, 11AA01.

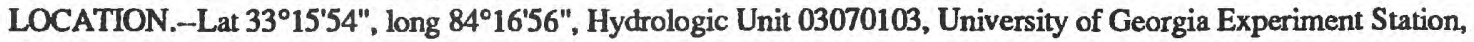

Experiment, Ga.

Owner: University of Georgia.

AQUIFER.-Surficial (residurum).

WELL CHARACTERISTICS.--Dug unused supply well, size $4 \times 4 \mathrm{ft}$, depth $30 \mathrm{ft}$, cased to $30 \mathrm{ft}$, open end.

DATUM.--Altitude of land-surface datum is $950 \mathrm{ft}$.

Measuring point: Top of recorder shelf, $3.1 \mathrm{ft}$ above land-surface datum.

REMARKS.-None.

PERIOD OF RECORD.--October 1943 to current year.

EXTREMES FOR PERIOD OF RECORD.--Highest water level, $8.26 \mathrm{ft}$ below land-surface datum, March 19, 1948; lowesh,

$21.82 \mathrm{ft}$ below land-surface datum, November 18-19, 1986.
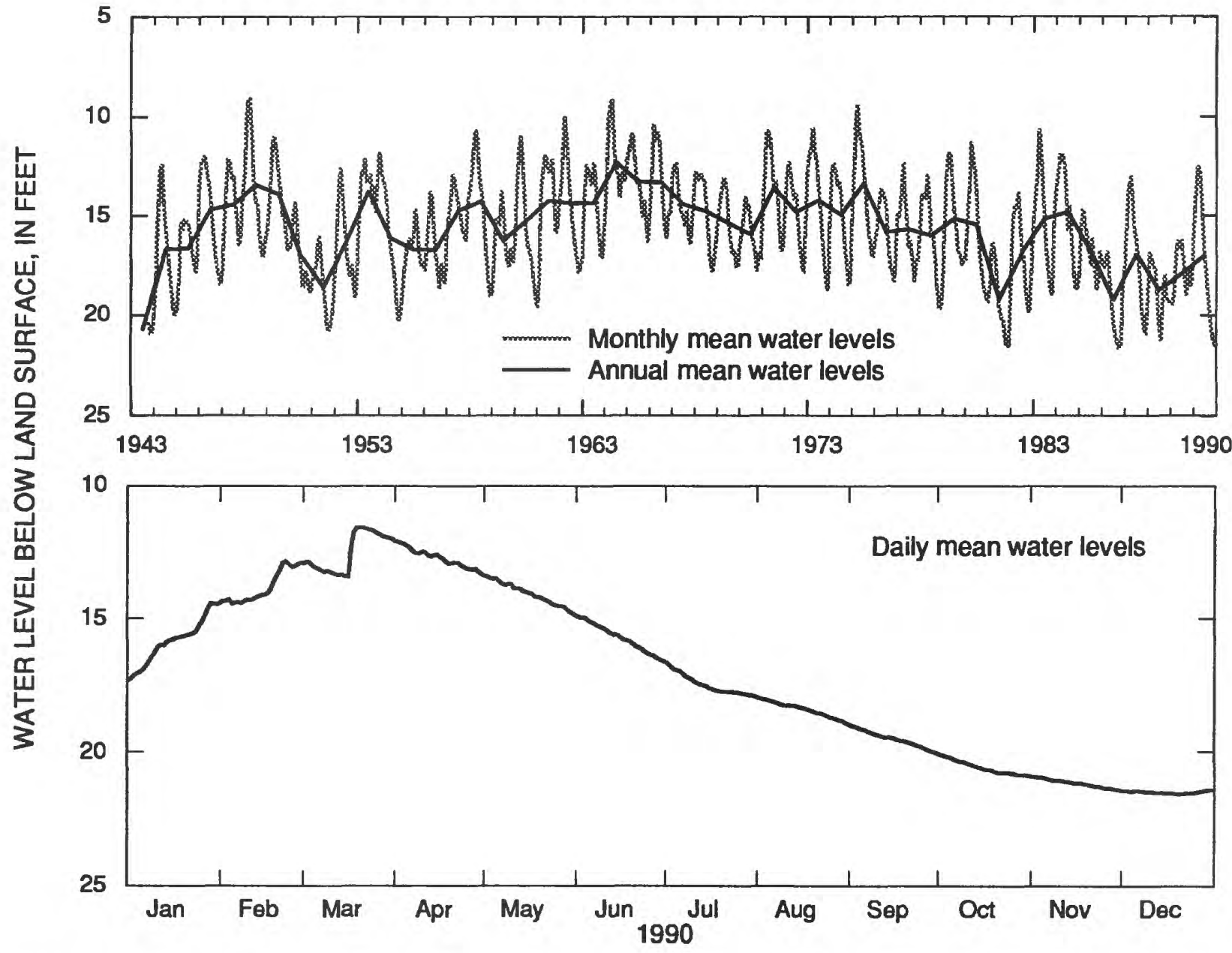

$\begin{array}{lllllllllllll}1990 & \text { JAN } & \text { FEB } & \text { MAR } & \text { APR } & \text { MAY } & \text { JUN } & \text { JUL } & \text { AUG } & \text { SEP } & \text { OCT } & \text { NOV } & \text { DEC } \\ \text { MEAN } & 15.88 & 13.84 & 12.51 & 12.71 & 14.06 & 15.70 & 17.45 & 18.38 & 19.48 & 20.55 & 21.13 & 21.47 \\ \text { LOW } & 17.23 & 14.43 & 13.41 & 13.32 & 14.84 & 16.59 & 17.89 & 18.91 & 20.02 & 20.87 & 21.40 & 21.55 \\ \text { HIGH } & 14.41 & 12.86 & 11.56 & 12.10 & 13.42 & 14.94 & 16.70 & 17.98 & 19.00 & 20.11 & 20.91 & 21.40 \\ \text { CAL YR } & 1990 & & \text { MEAN } & 16.95 & & \text { HIGH } & 11.56 & & \text { LOW } & 21.55 & & \end{array}$

Figure 15.--Water level in observation well 11AA01, Spalding County. 


\section{Southwestern area}

In the southwestern area, water levels are monitored in five wells that tap the surficial aquifer, two of which are summarized in this report (fig. 14). Both wells show water-level declines during most of 1990 as a result of below-normal rainfall (see precipitation graph for Albany, fig. 5). The annual mean water level in well 13M007 (fig. 16) in Worth County was about $0.4 \mathrm{ft}$ higher in 1990 than in 1989; whereas the annual mean water level in well $07 \mathrm{H} 003$ (fig. 17) in Miller County was about $4.7 \mathrm{ft}$ lower than in 1989. The long-term hydrographs indicate seasonal water-level declines as a result of seasonal decreases in precipitation, but long-term trends are not evident for the period of record in the wells. The difference in water-level response at the two wells results from areal variations in precipitation. 
314330084005403 Local number, $13 \mathrm{M} 007$.

LOCATION.--Lat $31^{\circ} 43^{\prime \prime} 30^{\prime \prime}$, long $84^{\circ} 00^{\circ} 54^{\prime \prime}$, Hydrologic Unit 03130006, westernmost of three observation wells, $50 \mathrm{ft}$ north of Georgia Highway 32, 1,400 ft east of the Flint River, 1.7 mi east of the intersection of Georgia Highways 32 and 91.

Owner: U.S. Geological Survey, test well DP-9.

AQUIFER.--Surficial (residuum).

WELL CHARACTERISTICS.--Drilled observation well, diameter 4 in., depth $25 \mathrm{ft}$, cased to $10 \mathrm{ft}$, open hole.

DATUM.-Altitude of land-surface datum is $230 \mathrm{ft}$.

Measuring point: Top of $4 \mathrm{in}$. casing, $1 \mathrm{ft}$ above land-surface datum.

REMARKS.--Water levels for period of missing record, February 28 to March 28, were estimated.

PERIOD OF RECORD.--April 1980 to current year.

EXTREMES FOR PERIOD OF RECORD.-Highest water level, $3.48 \mathrm{ft}$ below land-surface datum, March 7. 1984; lowest,

$13.03 \mathrm{ft}$ below land-surface datum, October 22, 1981.

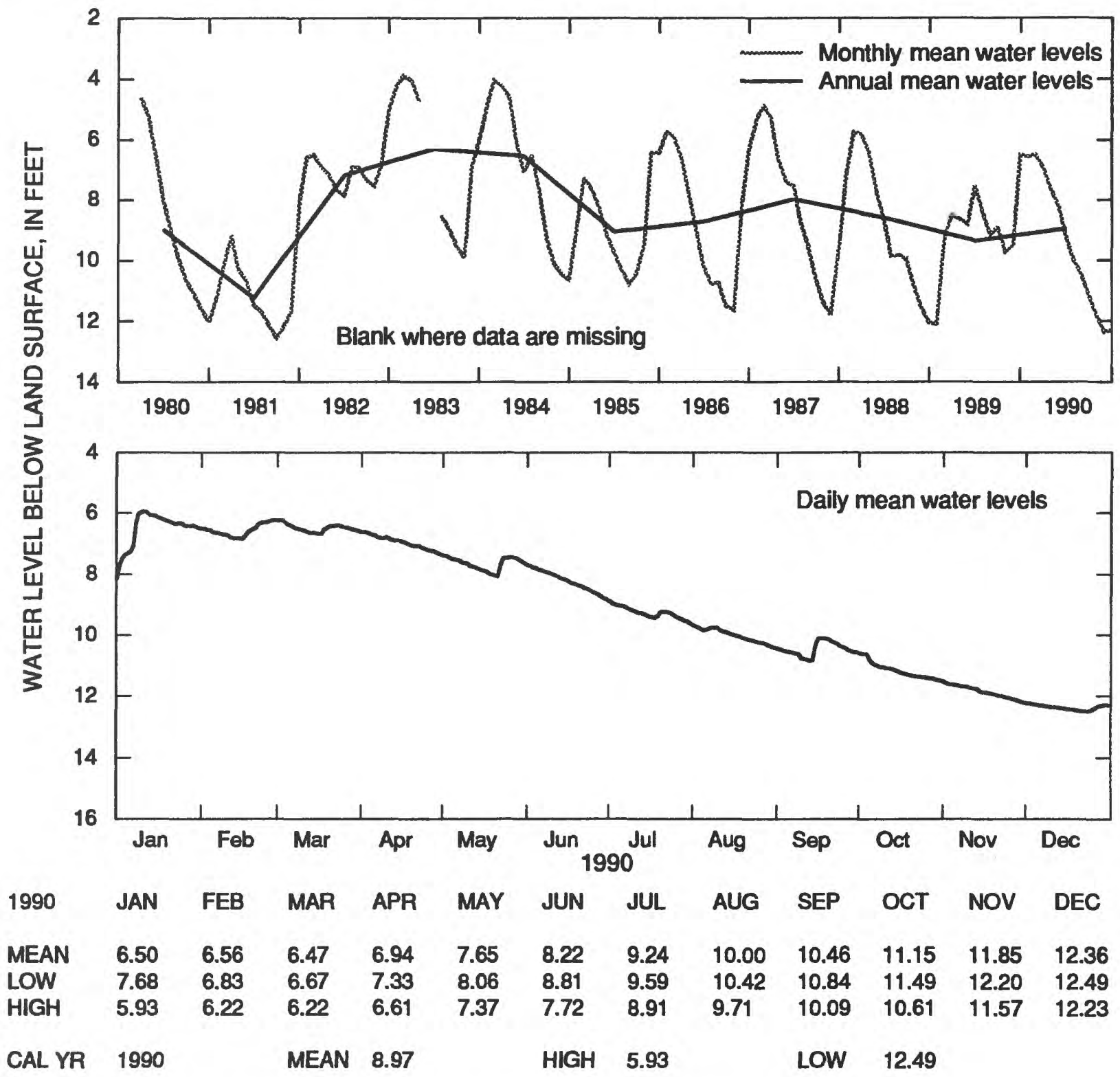

Figure 16.-Water level in observation well 13M007, Worth County. 
311009084495503 Local number, $07 \mathrm{H} 003$.

LOCATION.--Lat $31^{\circ} 10^{\prime} 08^{\prime \prime}$, long $84^{\circ} 49^{\prime} 54^{\prime \prime}$, Hydrologic Unit $03130010,0.2$ mi north on dirt road off Georgia Highway 273, 2.75 mi west of intersection of Georgia Highways 273 and 91.

Owner: U.S. Geological Survey, test well DP-3.

AQUIFER.-Surficial (residuum).

WELL CHARACTERISTICS.--Drilled observation well, diameter 4 in., depth $40 \mathrm{ft}$, perforated casing 30 to $40 \mathrm{ft}$.

DATUM.--Altitude of land-surface datum is $180 \mathrm{ft}$.

Measuring point: Top of recorder shelf, $3.0 \mathrm{ft}$ above land-surface datum.

REMARKS.-Well pumped and redeveloped August 11, 1989. Water levels for period of missing record, December 26-31, were estimated.

PERIOD OF RECORD.--February 1980 to current year.

EXTREMES FOR PERIOD OF RECORD.--Highest water level, $0.52 \mathrm{ft}$ below land-surface datum, March 6, 1984; lowest, $24.19 \mathrm{ft}$ below land-surface datum, November 10, 1981.

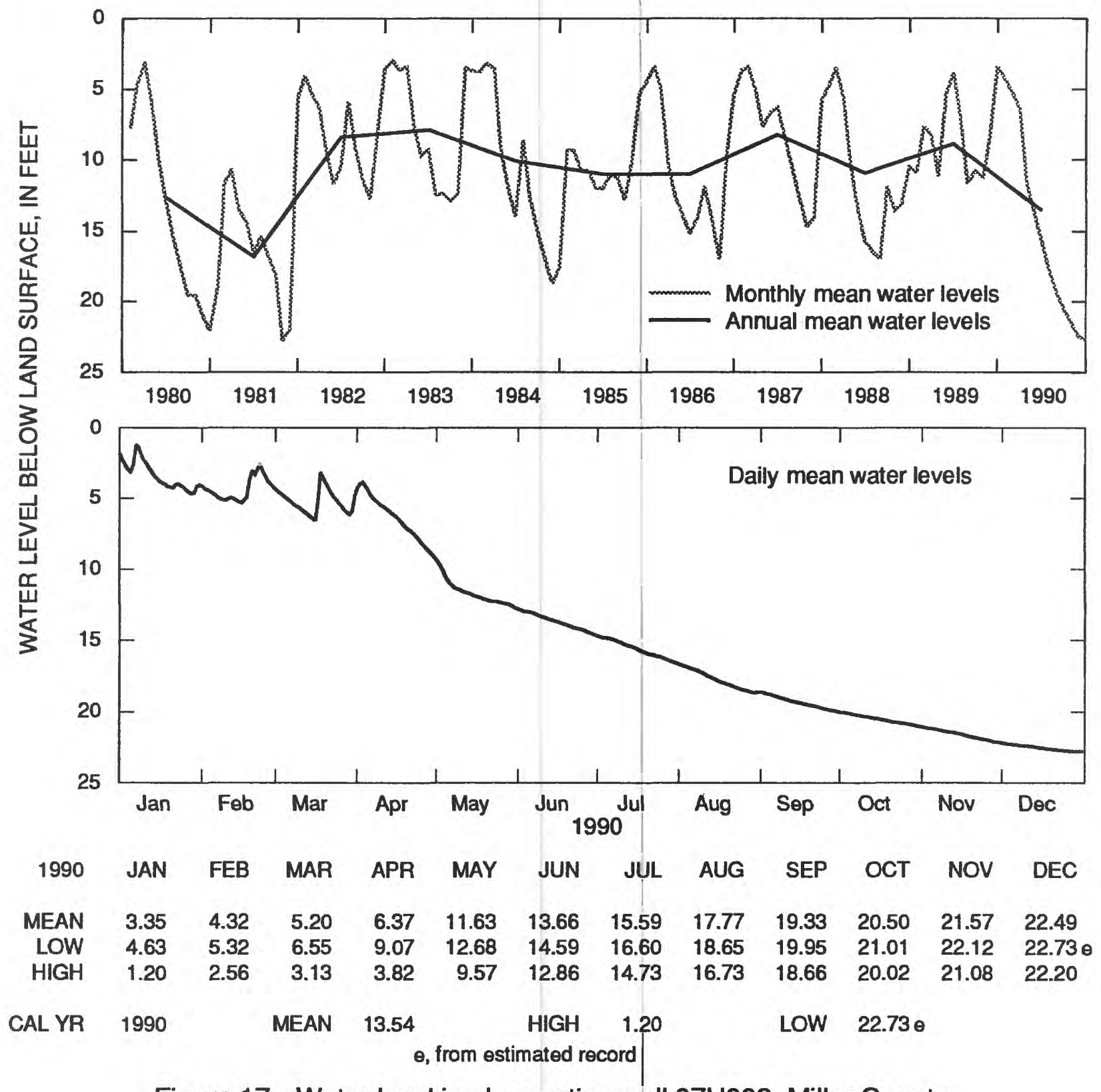

Figure 17.--Water level in observation well $07 \mathrm{H} 003$, Miller County. 


\section{Coastal area}

Water levels in surficial aquifers in the coastal area are monitored in six wells, five of which are summarized in this report (fig. 14). Throughout the coastal area, the surficial aquifers are recharged by precipitation.

Water levels in surficial aquifers in the northern part of the coastal area are affected by variations in precipitation, evapotranspiration, and natural drainage. At well 35P094 in Chatham County (fig. 18), recharge by precipitation is reflected by a sharp rise in the water level followed by a gradual decline resulting from evapotranspiration (Clarke and others, 1990, p. 22) (see precipitation graph for Savannah, fig. 11). The annual mean water level in this well was about the same in 1990 as in 1989. The water-level response to precipitation at wells 37P116 (fig. 19) and 32R003 (fig. 20) is less pronounced, because the wells tap deeper parts of the surficial aquifer where clay layers impede recharge from precipitation. In 1990, the annual mean water level in well 37P116 (fig. 19) in Chatham County was about the same as in 1989, and in well 32R003 (fig. 20) in Bulloch County was about $1.1 \mathrm{ft}$ lower than in 1989. Despite these variations, there is not an apparent long-term trend indicated on the period-of-record hydrographs for any of the three wells.

The water-level in the surficial aquifer in the Brunswick area is influenced by nearby pumping from the surficial aquifer, by precipitation, and by tidal fluctuations (Clarke and others, 1990, p. 24). The annual mean water level in well $34 \mathrm{H} 438$ (fig. 21) in Glynn County was about $0.3 \mathrm{ft}$ higher in 1990 than in 1989, continuing an upward trend that began in 1988. Although the annual mean water level was slightly higher in 1990, a recordlow daily mean water level was recorded in this well in July that was about $0.2 \mathrm{ft}$ lower than the previous record low.

In the Jesup, Wayne County, area, water-level fluctuations in the surficial aquifer reflect variations in precipitation. In 1990, the annual mean water level in well 32L017 (fig. 22) was about $0.2 \mathrm{ft}$ lower than in 1989, reversing a slight upward trend that began in 1988. Although the annual mean water level was slightly higher in 1990, a record-low daily mean water level was recorded in this well in October that was about $1.4 \mathrm{ft}$ lower than the previous record low. 
315950081161201 Local number, 35 P094.

LOCATION.--Lat 31 ${ }^{\circ} 59^{\prime} 50^{\prime \prime}$, long 81 ${ }^{\circ} 16^{\prime} 12^{\prime \prime}$, Hydrologic Unit 03060204, Barbour Lathrop Plant Introduction Station,

10 mi south of Savannah, north of the intersection of U.S. Highway 17 and Argyle Rd.

Owner: University of Georgia, formerly U.S. Department of Agriculture.

AQUFER.--Surficial (sand of Holocene and Pleistocene age).

WELL CHARACTERISTICS.--Bored observation well, diameter $30 \mathrm{in}$., depth $15 \mathrm{ft}$, cased to $15 \mathrm{ft}$, open end.

DATUM.--Altitude of land-surface datum is $18.67 \mathrm{ft}$.

Measuring point: Iron bracket on recorder shelf, $3.3 \mathrm{ft}$ above land-surface datum.

REMARKS.--Responds quickly to precipitation.

PERIOD OF RECORD.--August 1942 to current year.

EXTREMES FOR PERIOD OF RECORD.--Highest water level, $0.05 \mathrm{ft}$ below land-surface datum, September 26, 1953; lowest,

$12.28 \mathrm{ft}$ below land-surface datum, November 30, 1972.

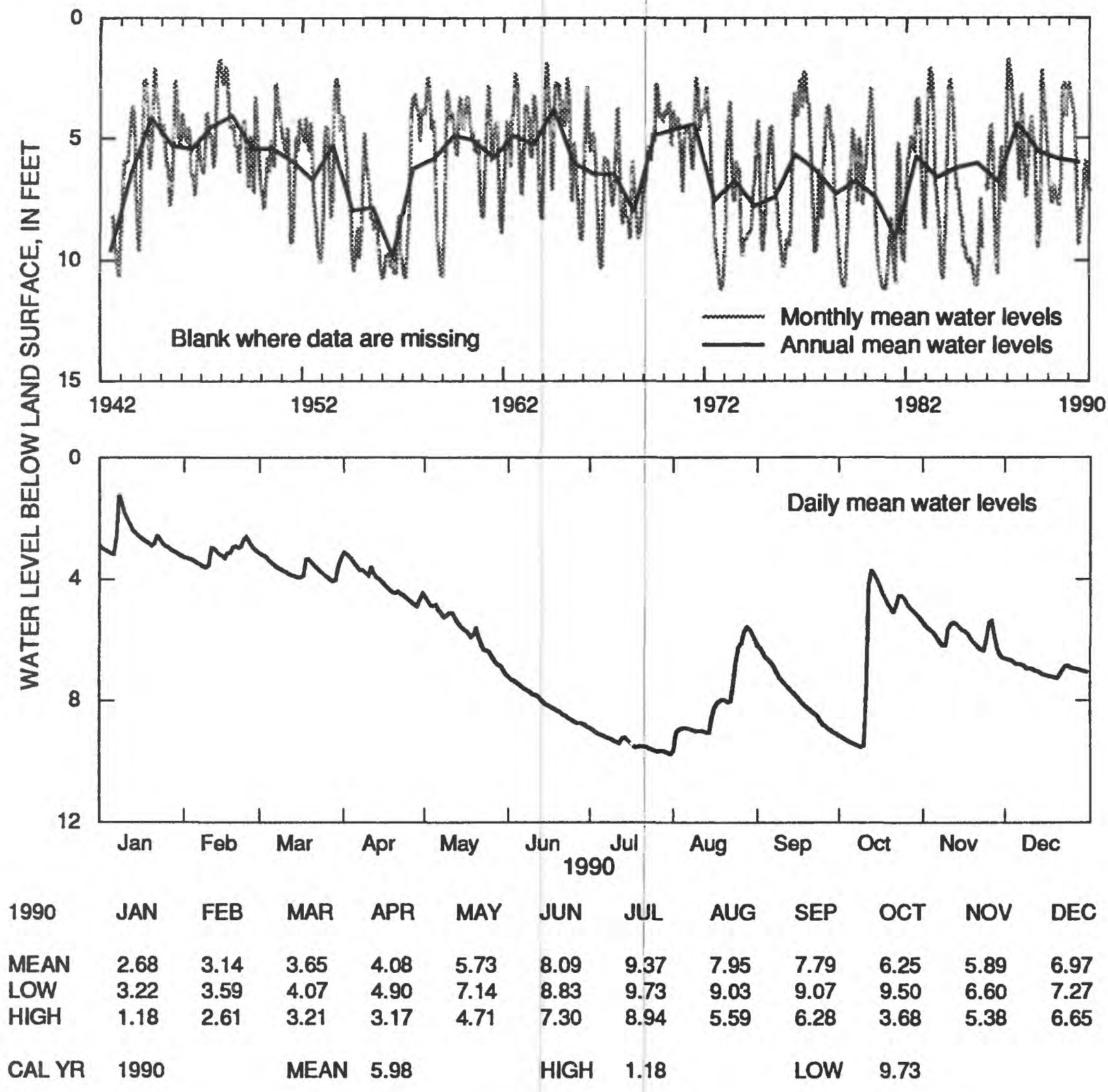

Figure 18.--Water level in observation well 35P094, Chatham County. 
315906081011204 Local number, 37P116.

LOCATION.--Lat $31^{\circ} 59^{\circ} 06^{\prime \prime}$, long $81^{\circ} 01^{\prime} 12^{\prime \prime}$, Hydrologic Unit 03060204, 1,300 ft southeast of University of Georgia Skidaway Institute.

Owner: Georgia Geologic Survey, Skidaway Institute test well 4.

AQUIFER.-Surficial (sand of Miocene and post Miocene age).

WELL CHARACTERISTICS.--Drilled observation well, diameter 6 in., depth $85 \mathrm{ft}$, cased to $70 \mathrm{ft}$, screen to $85 \mathrm{ft}$.

DATUM.-Altitude of land-surface datum is $10 \mathrm{ft}$.

Measuring point: Top of recorder shelf, $3.8 \mathrm{ft}$ above land-surface datum.

REMARKS.--None.

PERIOD OF RECORD.--January 11, 1984, to current year.

EXTREMES FOR PERIOD OF RECORD.--Highest water level, $7.19 \mathrm{ft}$ below land-surface datum, October 31, 1985; lowest, $9.03 \mathrm{ft}$ below land-surface datum, December 6, 1989.

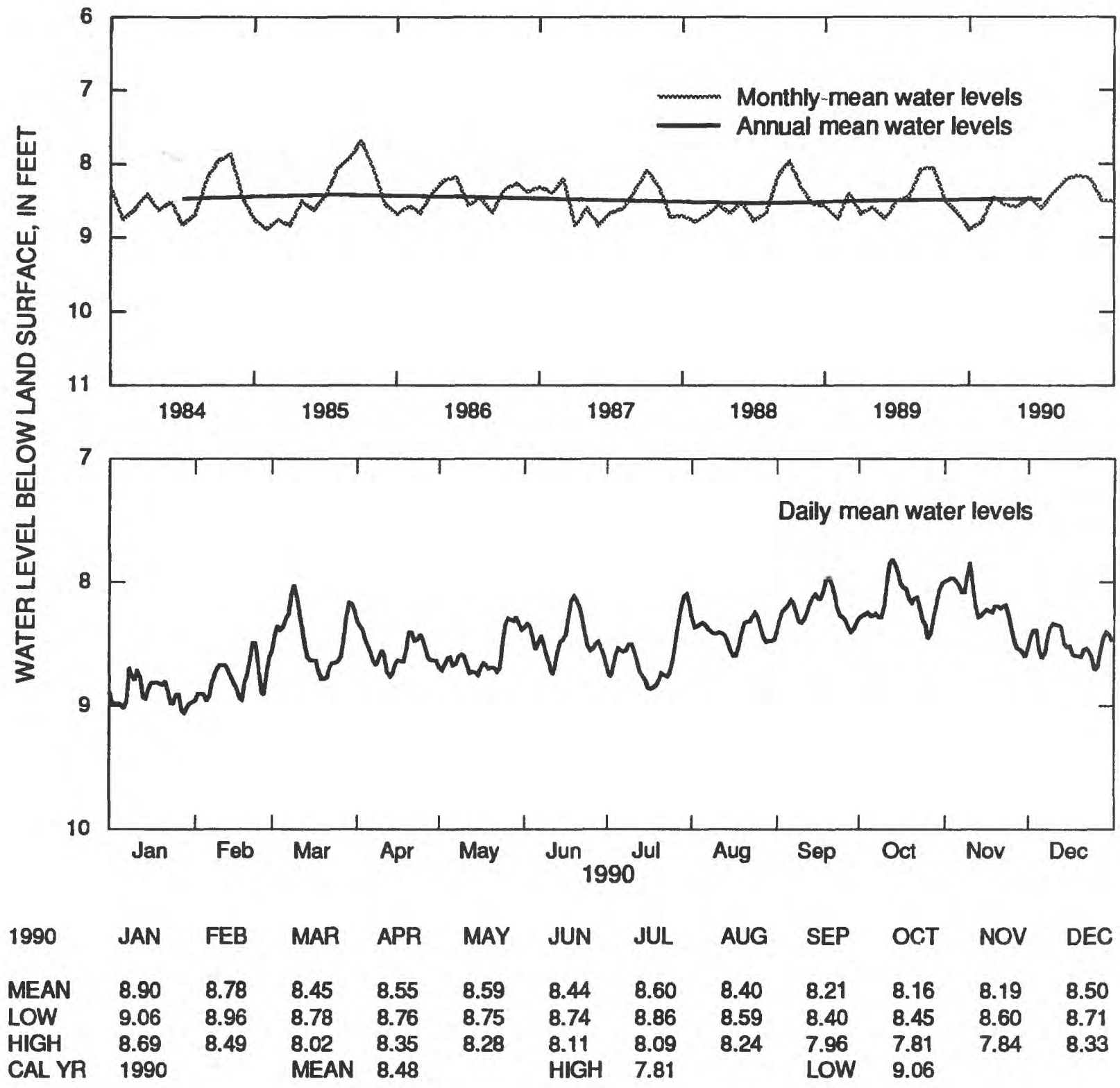

Figure 19.--Water level in observation well 37P116, Chatham County. 
321240081411502 Local number, 32R003.

LOCATION.--Lat 32'12'40", long $81^{\circ} 41^{\prime} 15^{\prime \prime}$, Hydrologic Unit 03060202, $2.6 \mathrm{mi}$ north along Georgia Highway 67 from the Bulloch-Bryan County line, approximately $100 \mathrm{ft}$ east of center line of road.

Owner: Georgia Geologic Survey, Bulloch South test well 2.

AQUIFER.--Surficial (sand of Miocene and post Miocene age).

WELL CHARACTERISTICS.--Drilled observation well, diameter 6 in., depth $155 \mathrm{ft}$, cased to $134 \mathrm{ft}$, screen to $155 \mathrm{ft}$.

DATUM.-Altitude of land-surface datum is $120 \mathrm{ft}$.

Measuring point: Top of recorder shelf, $3.0 \mathrm{ft}$ above land-surface datum.

REMARKS.--Well sounded August 1982.

PERIOD OF RECORD.--February 24, 1983, to current year.

EXTREMES FOR PERIOD OF RECORD.--Highest water level, $8.40 \mathrm{ft}$ below land-surface datum, March 26, 1983; lowest, $15.27 \mathrm{ft}$ below land-surface datum, November 14, 1983.

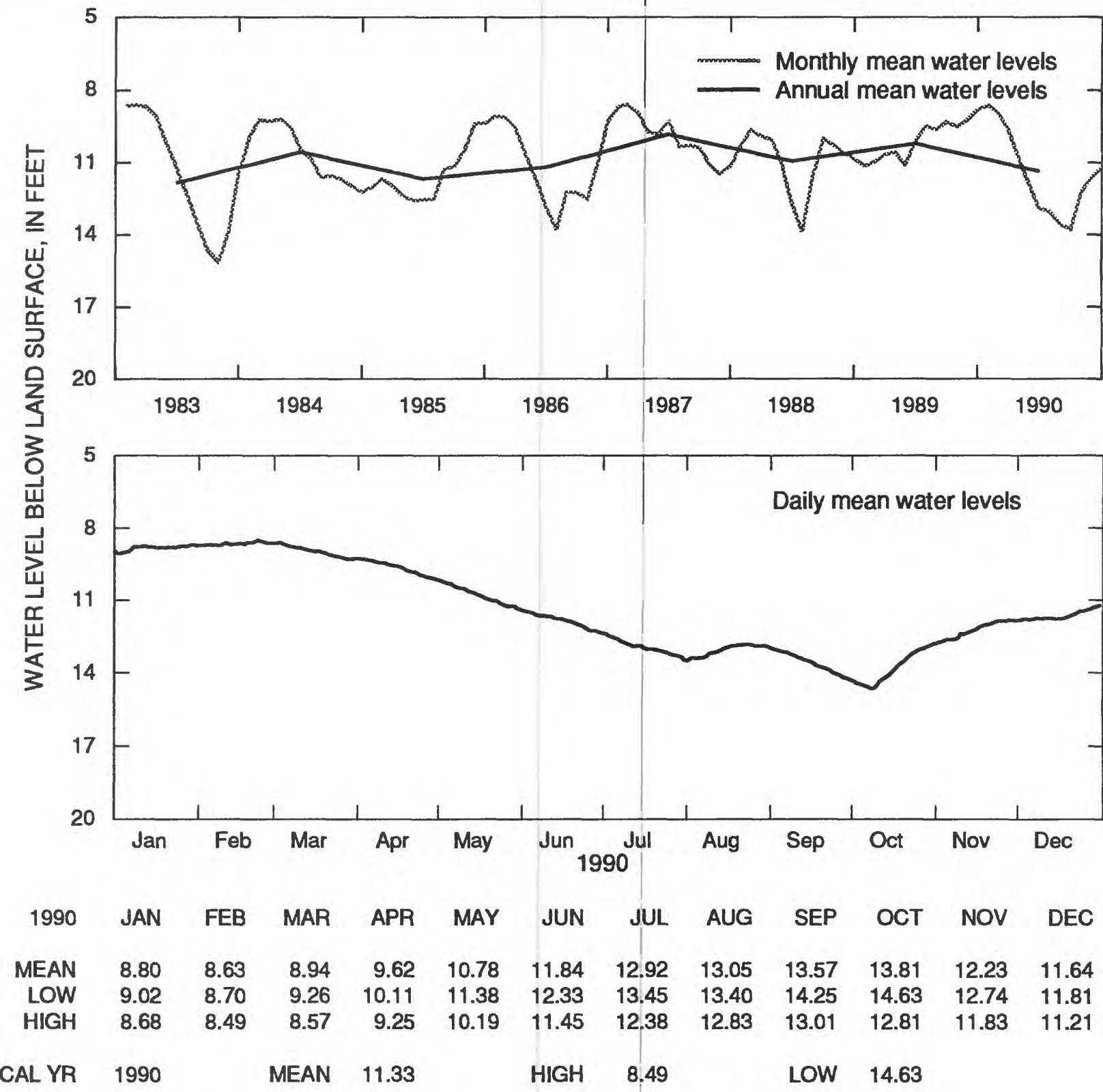

Figure 20.--Water level in observation well 32R003, Bulloch County. 
310901081284403 Local number, 34H438.

LOCATION.--Lat $31^{\circ} 09^{\prime} 01^{\prime \prime}$, long $81^{\circ} 28^{\prime} 44^{\prime \prime}$, Hydrologic Unit 03070203, easternmost of three observation wells at the north end of Coffin Park, near the intersection of U.S. Highway 17 and U.S. Highway 25, in Brunswick.

Owner: Georgia Geologic Survey, Coffin Park test well 3.

AQUIFER.--Surficial (sand of Miocene and post Miocene age).

WELL CHARACTERISTICS.--Drilled observation well, diameter 6 in., depth $202 \mathrm{ft}$, cased to $192 \mathrm{ft}$, screen to $202 \mathrm{ft}$. DATUM.--Altitude of land-surface datum is $7 \mathrm{ft}$.

Measuring point: Top of recorder shelf, $3.0 \mathrm{ft}$ above land-surface datum.

REMARKS.--Water levels from period of missing record, August 6-7, were estimated.

PERIOD OF RECORD.--November 30, 1983, to current year.

EXTREMES FOR PERIOD OF RECORD.--Highest water level, $3.79 \mathrm{ft}$ below land-surface datum, January 4, 1985; lowest,

$8.13 \mathrm{ft}$ below land-surface datum, July 12, 1990 .

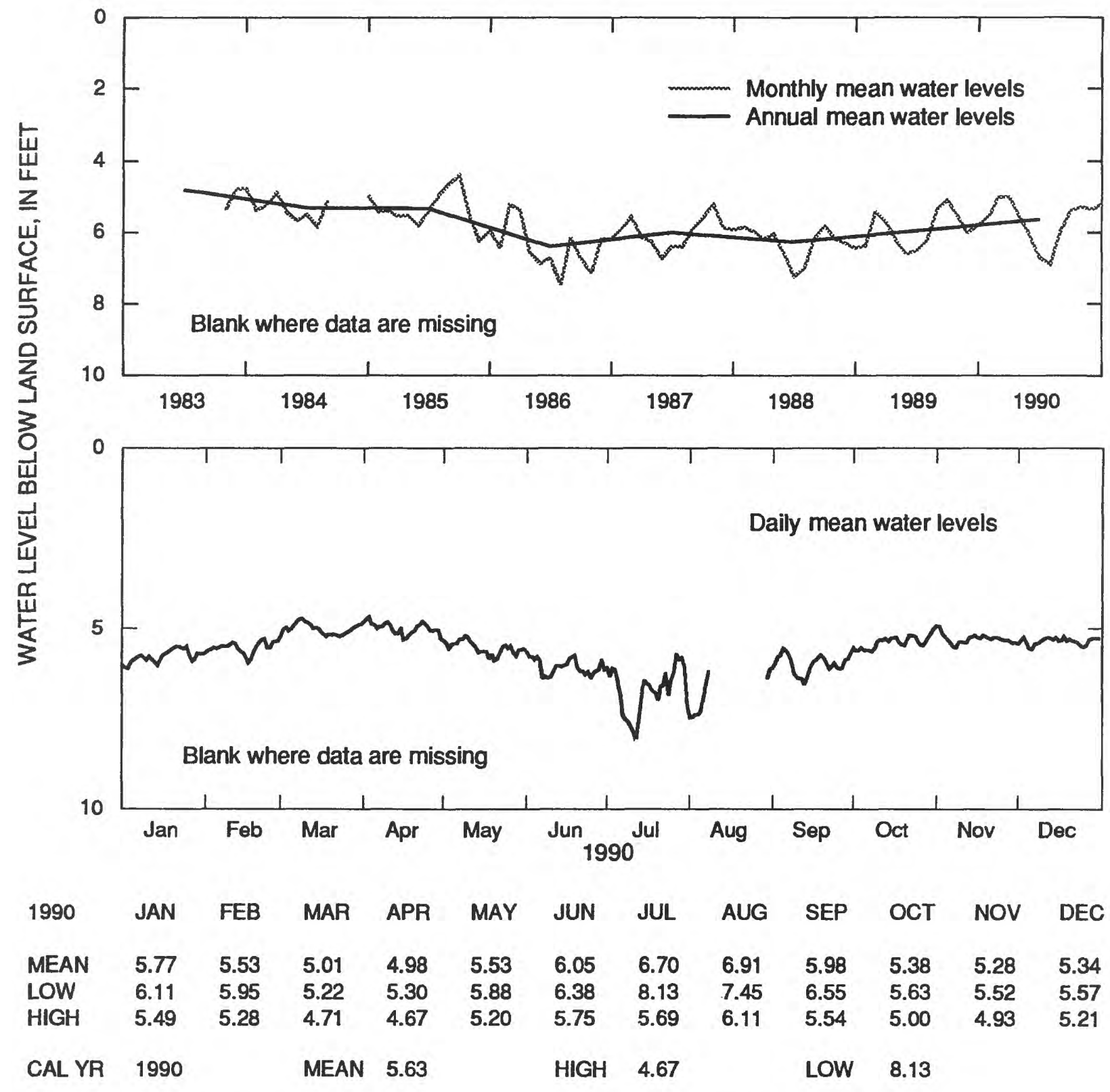

Figure 21.-Water level in observation well 34H438, Glynn County. 
313253081433504 Local number, 32L017.

LOCATION.--Lat 31'32'52", long 81 '43'36", Hydrologic Unit 03070106, easternmost of three recorder wells, $0.8 \mathrm{mi}$ north of Gardi Road, 4.3 mi east of Gardi.

Owner: Georgia Geologic Survey, Gardi test well 3.

AQUIFER.-Surficial (sand of Miocene and post-Miocene age).

WELL CHARACTERISTICS.--Drilled observation well, diameter 4 in., depth $215 \mathrm{ft}$, cased to $200 \mathrm{ft}$, screen to $215 \mathrm{ft}$.

DATUM.-Altitude of land-surface datum is $74 \mathrm{ft}$.

Measuring point: Top of recorder shelf, $4.0 \mathrm{ft}$ above land-surface datum.

REMARKS.-None.

PERIOD OF RECORD.--June 16, 1983, to current year.

EXTREMES FOR PERIOD OF RECORD.--Highest water level, $37.85 \mathrm{ft}$ below land-surface datum, April 16, 1984; lowest, $43.91 \mathrm{ft}$ below land-surface datum, October 8, 1990.

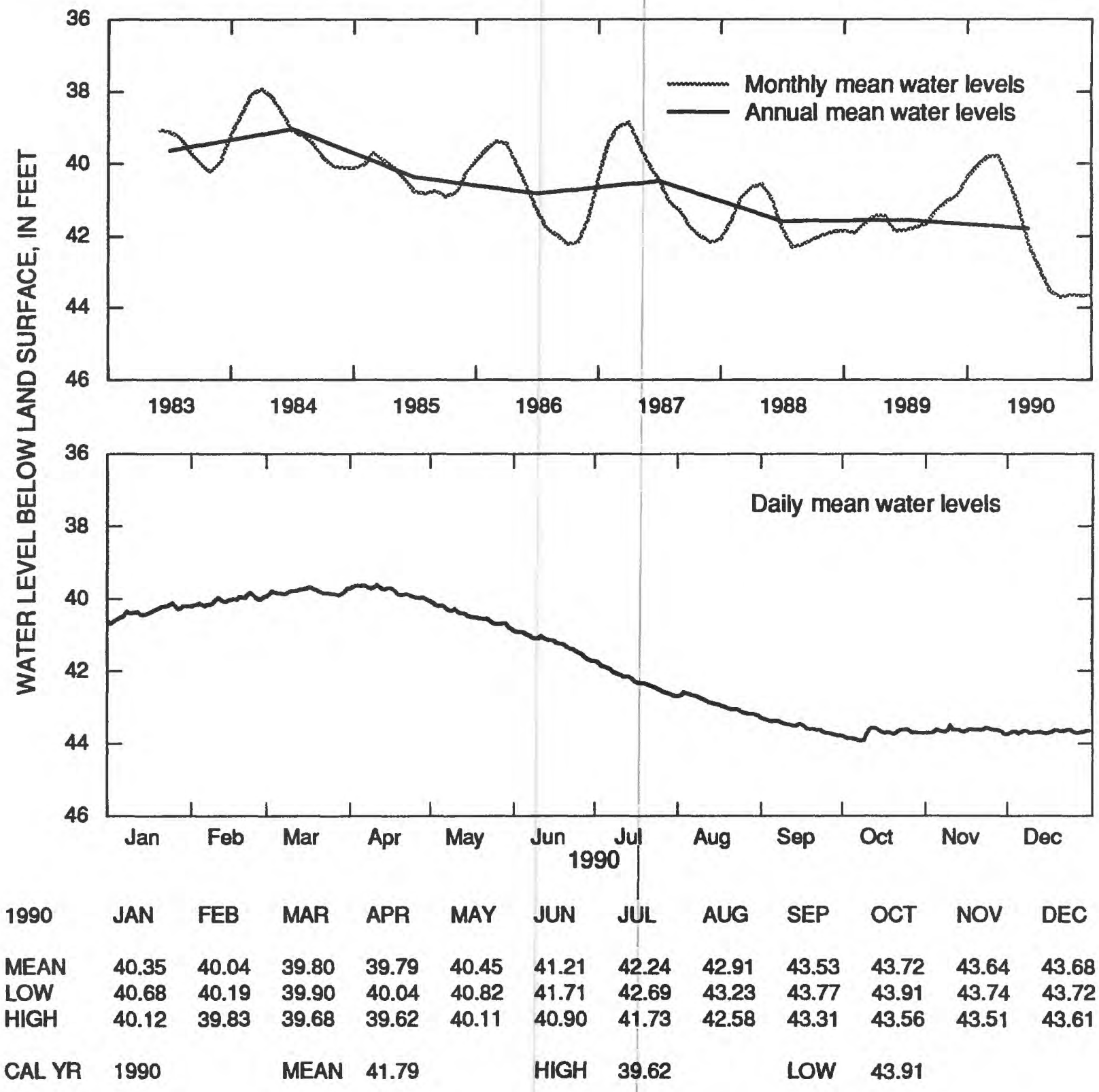

Figure 22.-Water level in observation well 32L017, Wayne County. 


\section{Upper Brunswick Aquifer}

The water level in the upper Brunswick aquifer is monitored in three wells, and data for these wells are summarized in this report (fig. 23). Near pumping centers of the Floridan aquifer system, the water level in the upper Brunswick aquifer responds to pumping from the Upper Floridan as a result of the hydraulic connection between the aquifers (Clarke and others, 1990, p. 28). Near outcrop areas, the water level primarily responds to seasonal variations in precipitation, although regional pumping from the Floridan aquifer system has some influence.

The upper Brunswick aquifer in Bulloch County is under unconfined to semi-confined conditions. The water level here is influenced by both variations in recharge from precipitation and by pumping from the Upper Floridan aquifer (Clarke and others, 1990, p. 28). The annual mean water level in well 31 U009 (fig. 24) was about $0.5 \mathrm{ft}$ lower in 1990 than in 1989. A long-term trend is not apparent for this well.

In the Wayne and Glynn County areas, the upper Brunswick aquifer is confined and responds to nearby pumping. In 1990, the annual mean water level in well $32 \mathrm{L016}$ near Jesup (fig. 25) was about $1.0 \mathrm{ft}$ lower than in 1989, continuing a downward trend that began in 1984, which is similar to trends in the underlying Upper Floridan aquifer (see hydrographs for well 30L003, fig. 55, and well 32L015, fig. 56.). A record-low daily mean water level was recorded in well $32 \mathrm{LO16}$ (fig. 25) in October that was about $1.8 \mathrm{ft}$ lower than the previous record low. The annual mean water level in well 34H437 near Brunswick (fig. 26) was about $1.2 \mathrm{ft}$ higher in 1990 than in 1989, reversing the downward trend that began in 1984. 


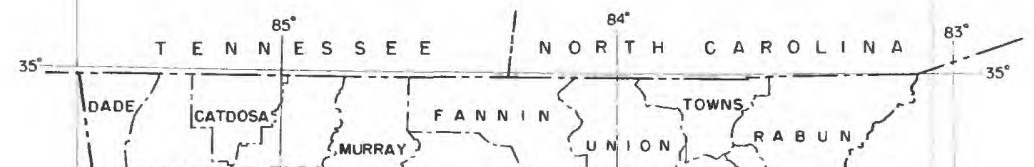

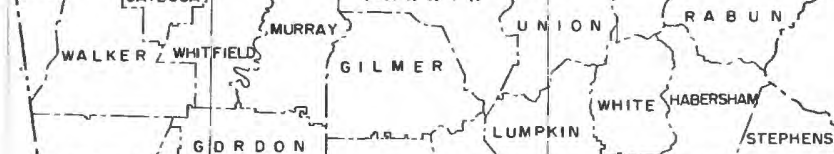
Chatrogaj'jegRoon CARroll OOUGLas \&

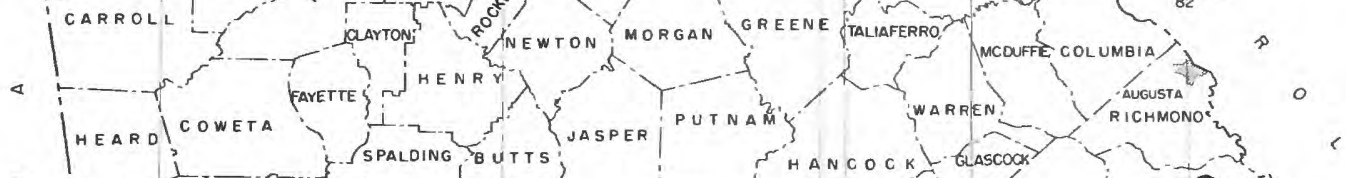

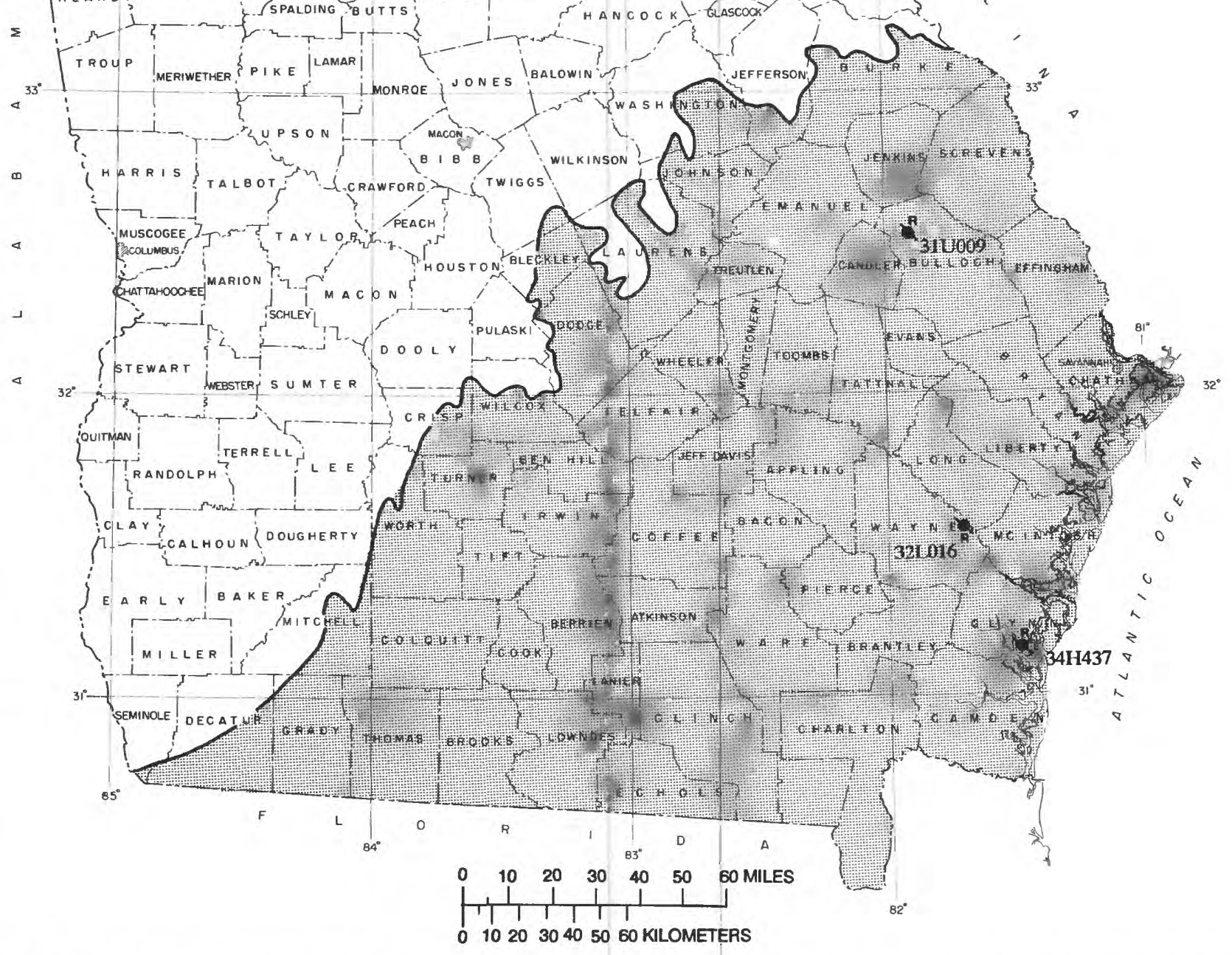

Figure 23.--Locations of observation wells completed in the upper Brunşwick aquifer. (The extent of the upper Brunswick aquifer has not been mapped, but is within the area of Miocene deposits shown.) 
323123081511602 Local number, 31 U009.

LOCATION.--Lat 32³1'23", long 81 ${ }^{\circ} 51^{\prime} 16^{\prime \prime}$, Hydrologic Unit 03060202, in roadside park on west side of Hopeulikit community, U.S. Highways 25 and 80.

Owner: Georgia Geologic Survey, Hopeulikit test well 2.

AQUIFER.--Upper Brunswick.

WELL CHARACTERISTICS.--Drilled observation well, diameter 6 in., depth $210 \mathrm{ft}$, cased to $160 \mathrm{ft}$, screen to $210 \mathrm{ft}$.

DATUM.--Altitude of land-surface datum is $205 \mathrm{ft}$.

Measuring point: Top of recorder shelf, $3.0 \mathrm{ft}$ above land-surface datum.

REMARKS.--Well sounded August 1982.

PERIOD OF RECORD.--October 1982 to current year.

EXTREMES FOR PERIOD OF RECORD.--Highest water level, 70.77 ft below land-surface datum, April 24, 1983; lowest,

$78.87 \mathrm{ft}$ below land-surface datum, August 4, 1986.

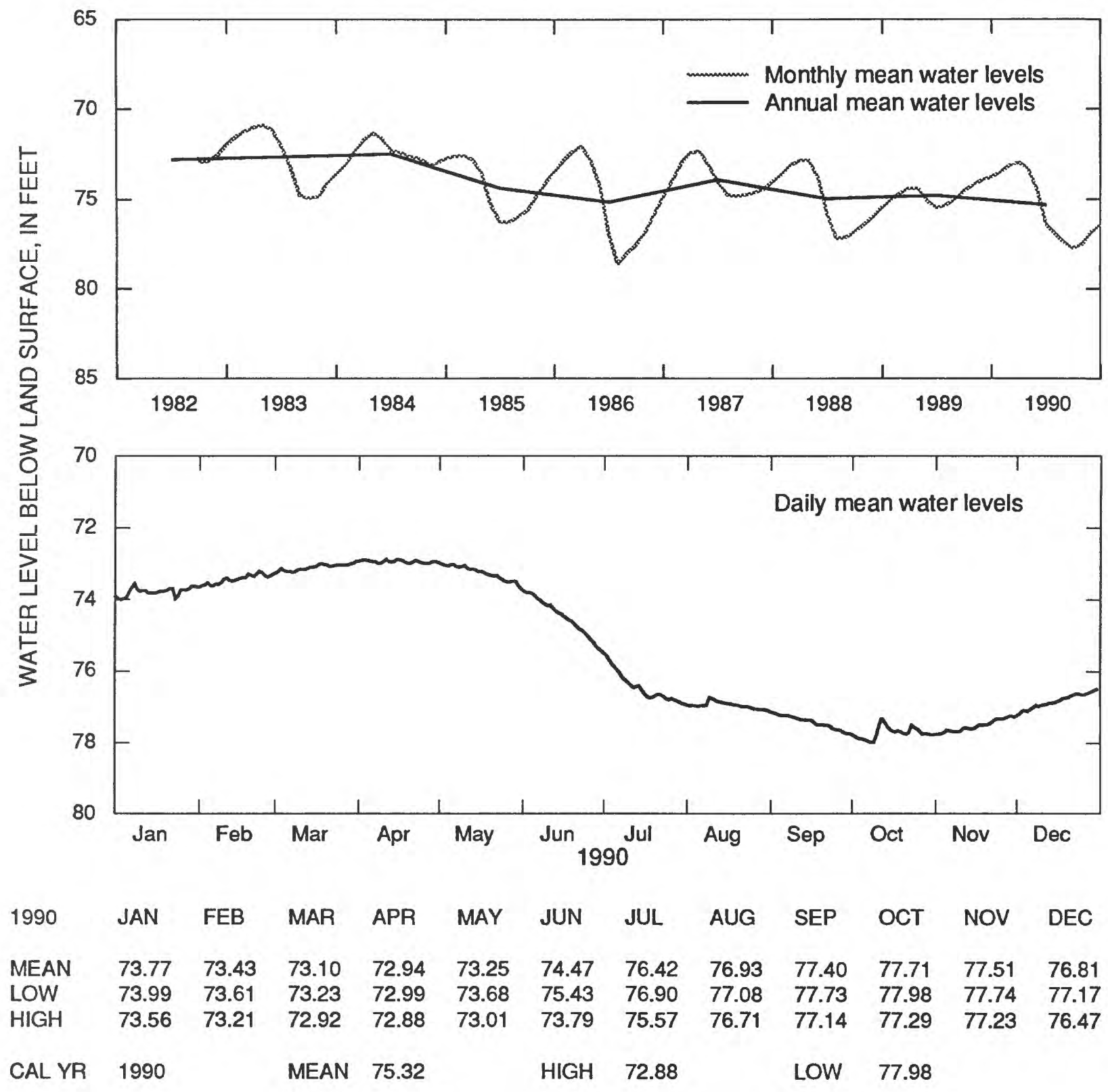

Figure 24.--Water level in observation well 31U009, Bulloch County. 
313253081433503, Local number, 32L016.

LOCATION.--Lat 31 32 '52", long 81 $43^{\prime 3} 36^{\prime \prime}$, Hydrologic Unit 03070106 , middle well of three recorder wells, 0.8 mi north of Gardi Road, on right side of dirt road, $4.3 \mathrm{mi}$ east of Gardi.

Owner: Georgia Geologic Survey, Gardi test well 2.

AQUIFER.--Upper Brunswick.

WELL CHARACTERISTICS.--Drilled observation well, diameter 4 in., depth $340 \mathrm{ft}$, cased to $320 \mathrm{ft}$, screen to $340 \mathrm{ft}$.

DATUM.--Altitude of land-surface datum is $74 \mathrm{ft}$.

Measuring point: Top of recorder shelf, $4.0 \mathrm{ft}$ above land-surface datum.

REMARKS.--Well sounded April 26, 1983.

PERIOD OF RECORD.--June 1983 to current year.

EXTREMES FOR PERIOD OF RECORD.--Highest water level, $49.26 \mathrm{ft}$ below land-surface datum, March 20, 1984; lowest,

$56.88 \mathrm{ft}$ below land-surface datum, October 8, 1990.

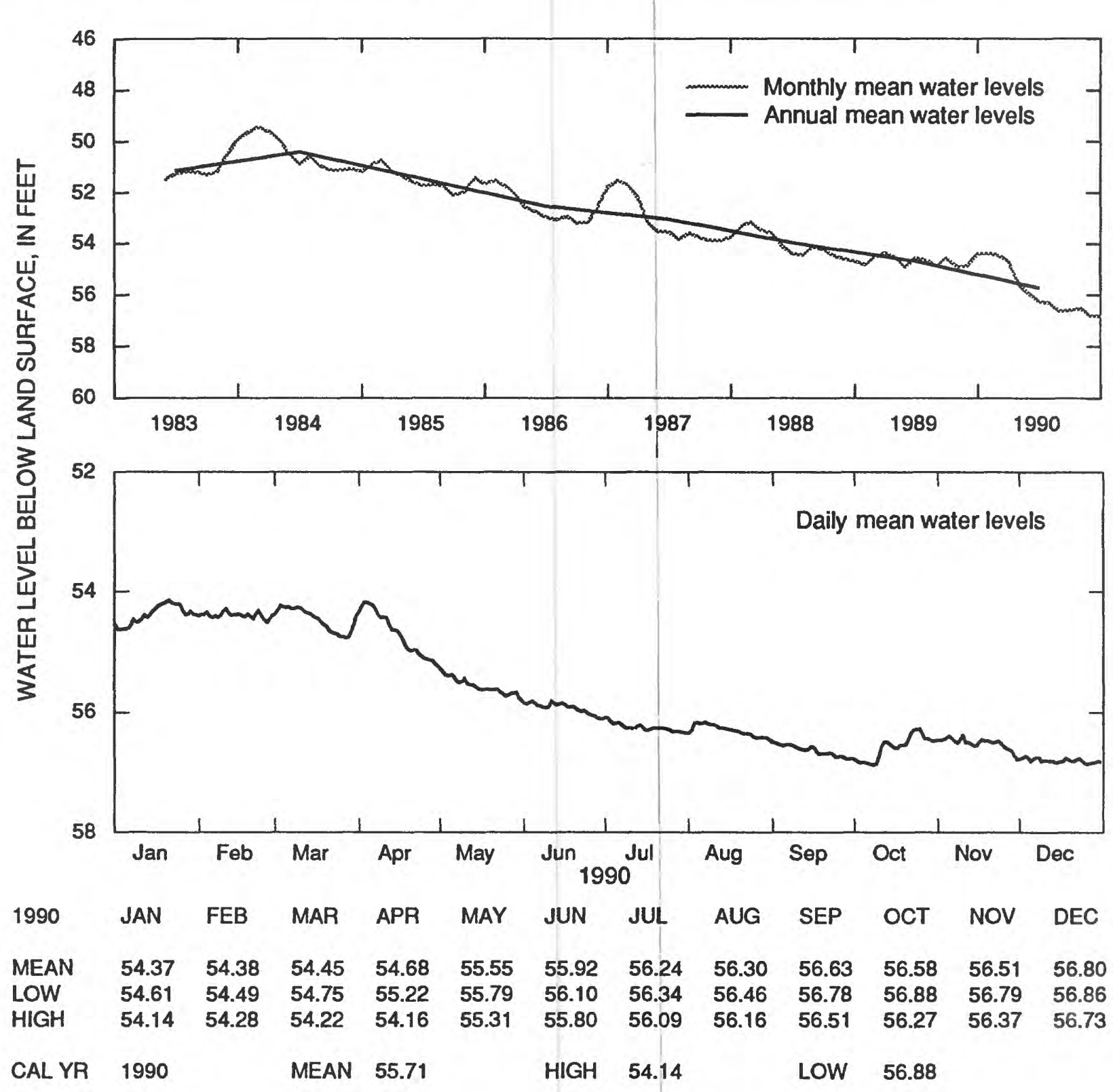

Figure 25.--Water level in observation well 32L016, Wayne County. 
310901081284402 Local number, $34 \mathrm{H} 437$.

LOCATION.--Lat $31^{\circ} 09^{\prime} 01^{\prime \prime}$, long $81^{\circ} 28^{\prime} 44^{\prime \prime}$, Hydrologic Unit 03070203, middle well of three recorder wells at the north end of Coffin Park near the intersection of U.S. Highway 17 and U.S. Highway 25.

Owner: Georgia Geologic Survey, Coffin Park test well 2.

AQUIFER.-U Upper Brunswick.

WELL CHARACTERISTICS.--Drilled observation well, diameter 4 in., depth $328 \mathrm{ft}$, cased to $315 \mathrm{ft}$, screen to $328 \mathrm{ft}$.

DATUM.-Altitude of land-surface datum is $7 \mathrm{ft}$.

Measuring point: Top of recorder shelf, $3.0 \mathrm{ft}$ above land-surface datum.

REMARKS.-None.

PERIOD OF RECORD.--January 21, 1984, to current year.

EXTREMES FOR PERIOD OF RECORD.--Highest water level, $2.26 \mathrm{ft}$ above land-surface datum, January 7, 1985; lowest, $7.80 \mathrm{ft}$ below land-surface datum, August 30, 1987.
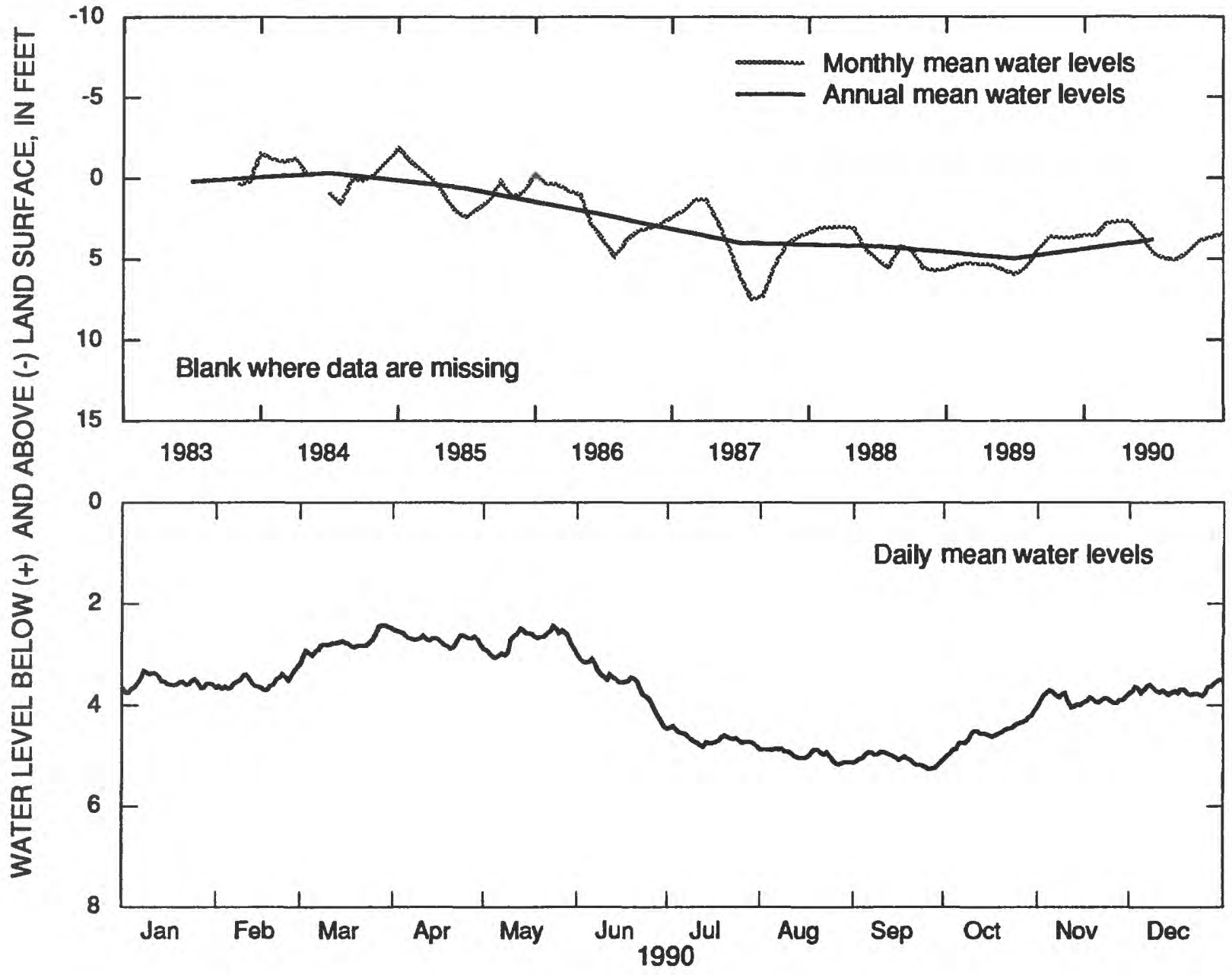

$\begin{array}{lllllllllllll}1990 & \text { JAN } & \text { FEB } & \text { MAR } & \text { APR } & \text { MAY } & \text { JUN } & \text { JUL } & \text { AUG } & \text { SEP } & \text { OCT } & \text { NOV } & \text { DEC } \\ \text { MEAN } & 3.54 & 3.53 & 2.77 & 2.68 & 2.71 & 3.54 & 4.65 & 4.96 & 5.06 & 4.55 & 3.88 & 3.69 \\ \text { LOW } & 3.73 & 3.69 & 3.01 & 2.88 & 3.05 & 4.41 & 4.81 & 5.15 & 5.25 & 4.99 & 4.04 & 3.81 \\ \text { HIGH } & 3.31 & 3.24 & 2.42 & 2.53 & 2.43 & 3.07 & 4.40 & 4.84 & 4.90 & 4.10 & 3.70 & 3.48 \\ \text { CAL YR } & 1990 & & \text { MEAN } & 3.80 & & \text { HIGH } & 2.42 & & \text { LOW } & 5.25 & & \end{array}$

Figure 26.--Water level in observation well 34H437, Glynn County. 


\section{Floridan Aquifer System}

Water levels in the Floridan aquifer system are monitored in 59 wells, 32 of which are summarized in this report (figs. 27 and 62). The Floridan aquifer system includes the Upper and Lower Floridan aquifers (table 1). In and near outcrop areas, the Upper Floridan aquifer is semi-confined and water levels in wells tapping this aquifer fluctuate seasonally in response to variations in recharge rate and pumping (Clarke and others, 1990). Near the coast, where the Upper Floridan aquifer is confined, water levels respond primarily to pumping, and fluctuations related to recharge are less pronounced (Clarke and others, 1990, p. 31). In Georgia, about $655 \mathrm{Mgal} / \mathrm{d}$ are pumped from the Floridan aquifer system, mostly for industrial and irrigation purposes (Pierce and Kundell, 1990). All, but a small percentage of the water withdrawn from the Floridan aquifer system is from the Upper Floridan aquifer; a few wells in the Savannah area withdraw water from the Lower Floridan aquifer. Little is known about the hydrogeology of the Lower Floridan aquifer.

\section{Upper Floridan aquifer}

The water-level in the Upper Floridan aquifer is monitored in 53 wells, 30 of which are summarized in this report (fig. 27). In this report, the Upper Floridan aquifer is divided areally into four hydrologic areas for discussion of water-level fluctuations and trends: (1) the southwestern area; (2) the south-central area; (3) the east-central area; and (4) the coastal area (fig. 27). These areas were divided on the basis of similar water-level changes in response to variations in recharge and discharge.

During May and June 1990, water levels were measured in 1,072 wells tapping the Upper Floridan aquifer in Georgia and adjacent parts of Alabama, Florida, and South Carolina; these water levels were used to construct a map showing the configuration of the water-level surface (Peck, 1991) (fig. 28). The general configuration of the water-level surface changed little from that of 1985 (Clarke and others, 1986, fig. 2.7-1). 


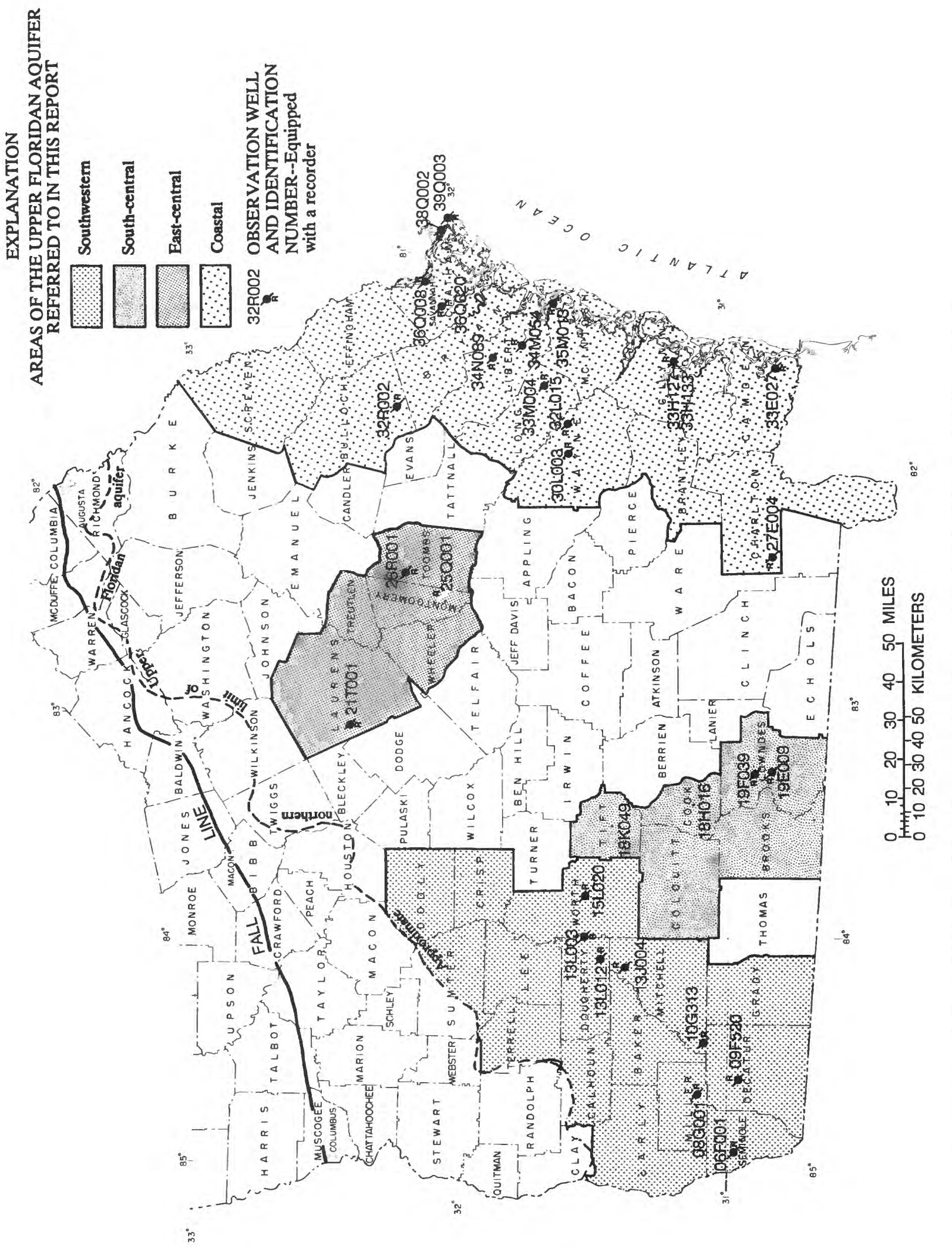

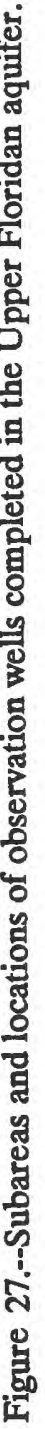




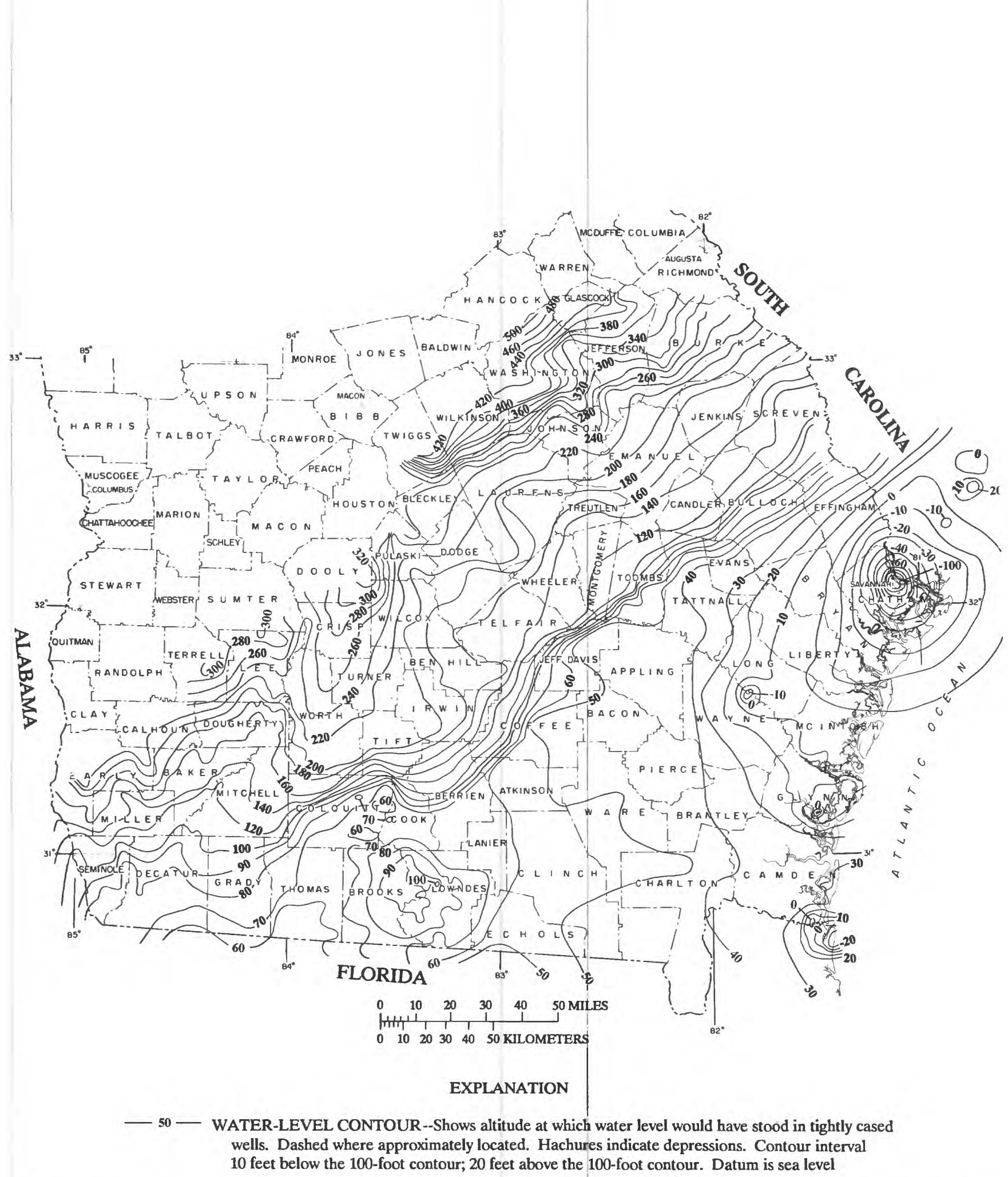

Figure 28.--Water level and locations of observation wells completed in the Upper Floridan aquifer in Georgia and adjacent parts of Alabama, Florida, and South Carolina, May-June 1990. From Peck (1991). 


\section{Southwestern area}

The water level in the Upper Floridan aquifer in southwestern Georgia is monitored in 23 wells, 8 of which are summarized in this report (fig. 27). In the southwestern area, water levels in wells tapping the Upper Floridan aquifer respond to variations in precipitation, evapotranspiration, pumping, and streamflow (Hayes and others, 1983, p. 16). During 1987, an estimated $377 \mathrm{Mgal} / \mathrm{d}$ were withdrawn from aquifers in southwestern Georgia (Trent and others, 1990), primarily from the Upper Floridan aquifer for irrigation. This large withdrawal has not produced a discernible cone of depression over most of the area because the wells are widely separated, the transmissivity of the aquifer is high, and recharge to the aquifer is large. The large withdrawal also has not caused long-term water-level declines over most of the area because pumping is seasonal and recharge is adequate during periods of normal precipitation. Although pumping has not produced a cone of depression or long-term water-level declines over most of the area, in the Sylvester, Worth County, area, a cone of depression has developed as a result of local pumping and the less-productive water-bearing characteristics of the aquifer in that area (D.W. Hicks, U.S. Geological Survey, oral commun., 1990).

During October 1990, water levels were measured in 148 wells tapping the Upper Floridan aquifer in the Albany area and a water-level map was constructed (Milby, 1991) (fig. 29). The general configuration of the water-level surface changed little from that of 1989 (Peck and others 1990, fig. 28).

The annual mean water levels in wells 09F520 (fig. 30), 08G001 (fig. 31), 06F001(fig. 32), and 13L012 (fig. 33) tapping the Upper Floridan aquifer ranged from about the same to about $0.9 \mathrm{ft}$ higher in 1990 than in 1989 , continuing a slight upward trend that began in 1988. The effect of irrigation pumping from a nearby well can be seen in the hydrograph for well 09F520 (fig. 30). A record-low daily mean water level was recorded in well 09F520 (fig. 30) in September that was slightly lower than the previous record low. These four wells are located near the Flint River or its tributaries where the aquifer is hydraulically connected to surface streams.

Away from the Flint River and its tributaries, the Upper Floridan aquifer is confined by thicker overburden and is not well connected to streams. In these areas, the water level is not rapidly influenced by precipitation. Water-level fluctuations and trends in these areas can be seen in the hydrographs for wells $10 G 313$ (fig. 34), 13L003 (fig. 35), $13 \mathrm{J004}$ (fig. 36), and 15L020 (fig. 37). The annual mean water levels in wells $10 \mathrm{G} 313$ (fig. 34), 13L003 (fig. 35), and $13 \mathrm{~J} 004$ (fig. 36) were from about 1.0 to about $3.2 \mathrm{ft}$ higher in 1990 than in 1989, reversing downward trends that began in 1987. The annual mean water level in well 15L020 (fig. 37) was about $1.0 \mathrm{ft}$ lower in 1990 than in 1989, continuing a downward trend. A record-low daily mean water level was recorded in well $15 \mathrm{LO20}$ (fig. 37) in August that was about $1.2 \mathrm{ft}$ lower than the previous record low. The continued decline in water-levels in well $15 \mathrm{~L} 020$ possibly is a result of increased local pumping and the lessproductive water-bearing characteristics of the aquifer in that area (D.W. Hicks, U.S. Geological Survey, oral commun., 1990). 


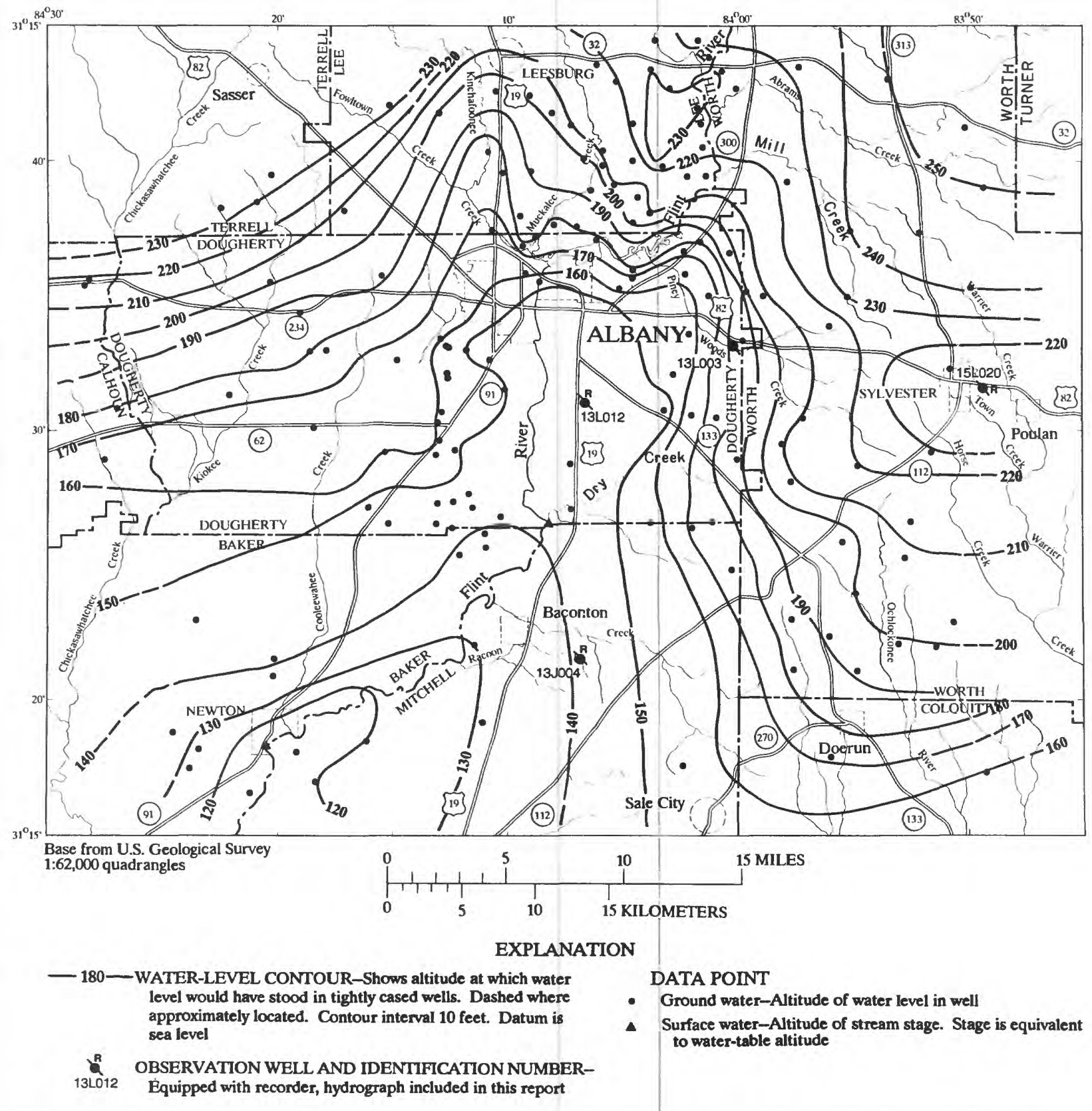

Figure 29.--Water level and locations of observation wells completed in the Upper Floridan aquifer in the Albany area, October 1990. From Milby (1991). 
305736084355801 Local number, 09F520.

LOCATION.--Lat $30^{\circ} 57^{\prime} 42^{\prime \prime}$, long $84^{\circ} 35^{\prime \prime} 46^{\prime \prime}$, Hydrologic Unit $03130008,0.5$ mi north of intersection of White's Mill Road and railroad track, 1.0 mi east of U.S. Highway 27 north of Bainbridge.

Owner: Graham Bolton.

AQUIFER.--Upper Floridan aquifer.

WELL CHARACTERISTICS.--Unused irrigation well, diameter 12 in., depth $251 \mathrm{ft}$, cased to $130 \mathrm{ft}$, open hole.

DATUM.--Altitude of land-surface datum is $128 \mathrm{ft}$.

Measuring point: Top of recorder shelf, $3.50 \mathrm{ft}$ above land-surface datum.

REMARKS.--This well is about $15 \mathrm{ft}$ from an irrigation well.

PERIOD OF RECORD.--June 1969 to current year.

EXTREMES FOR PERIOD OF RECORD.--Highest water level, $34.86 \mathrm{ft}$ below land-surface datum, April 15, 1984; lowest,

$54.89 \mathrm{ft}$ below land-surface datum, September 22, 1990.

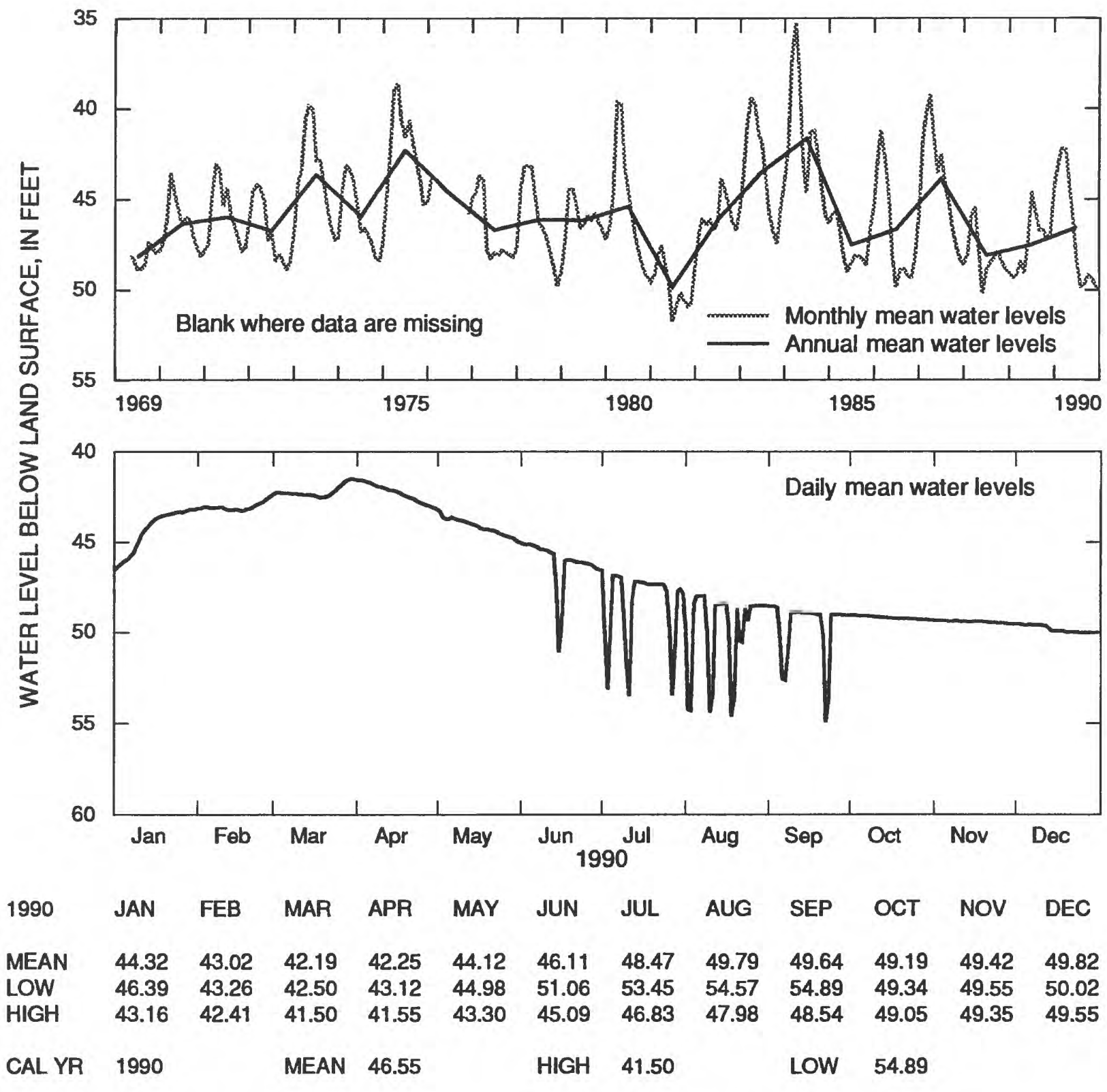

Figure 30.--Water level in observation well 09F520, Decatur County. 
310651084404501 Local number, 08G001.

LOCATION.--Lat $31^{\circ} 06^{\prime} 51^{\prime \prime}$, long $84^{\circ} 40^{\prime} 45^{\prime \prime}$, Hydrologic Unit $03130010,0.35$ mi east of Boykin on County Road 48, north on dirt road $0.6 \mathrm{mi}$ to dirt road, $0.3 \mathrm{mi}$ east to well on north side of road.

Owner: Viercocken.

AQUIFER.--Upper Floridan aquifer.

WELL CHARACTERISTICS.--Drilled unused irrigation well, diameter 12 in., depth $255 \mathrm{ft}$, cased to $130 \mathrm{ft}$, open hole.

DATUM.--Altitude of land-surface datum is $150 \mathrm{ft}$.

Measuring point: Top of recorder shelf, $3.0 \mathrm{ft}$ above land-surface datum.

REMARKS.-Water levels for periods of record August 1 to September 20, were estimated.

PERIOD OF RECORD.--February 1977 to current year.

EXTREMES FOR PERIOD OF RECORD.--Highest water level, $11.18 \mathrm{ft}$ below land-surface datum, April 11, 1984; lowest, $43.88 \mathrm{ft}$ below land-surface datum, July 17, 1981.

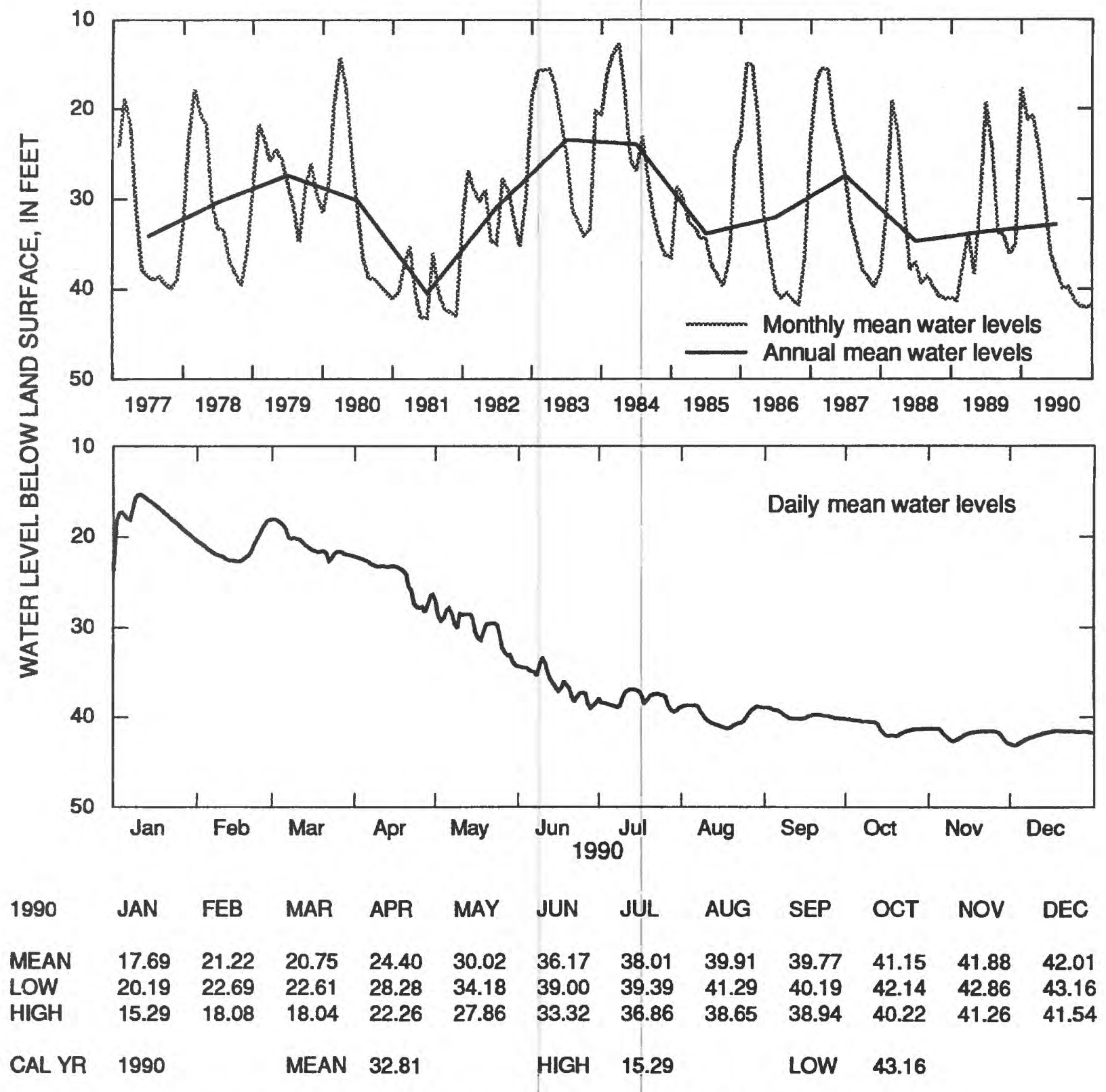

Figure 31.--Water level in observation well 08G001, Miller County. 
305356084534601 Local number, 06F001.

LOCATION.-Lat $30^{\circ} 54^{\prime} 01^{\prime \prime}$, long $84^{\circ} 53^{\prime} 40^{\prime \prime}$, Hydrologic Unit $03130004,9.8 \mathrm{mi}$ south of Donalsonville, $1.3 \mathrm{mi}$ west of Ga. Highway 39 on County Road 219, north 0.55 mi on Hebrew Road to dirt road, $0.5 \mathrm{mi}$ east on dirt road. Owner: Roddenbery Company Farms test well 1.

AQUIFER.--Upper Floridan aquifer.

WELL CHARACTERISTICS.--Drilled observation well, diameter 4 in., depth $150 \mathrm{ft}$, cased to $98.5 \mathrm{ft}$, open hole.

DATUM.--Altitude of land-surface datum is $110 \mathrm{ft}$.

Measuring point: Top of recorder shelf, $3.14 \mathrm{ft}$ above land-surface datum.

REMARKS.--Borehole geophysical survey conducted August 10, 1983. Well pumped and redeveloped August 10, 1989.

Water levels for period of missing record, May 20 to June 18, were estimated.

PERIOD OF RECORD.--March 1979 to July 1982, August 1983 to current year.

EXTREMES FOR PERIOD OF RECORD.--Highest water level, $4.13 \mathrm{ft}$ below land-surface datum, March 8, 1984; lowest, $35.65 \mathrm{ft}$ below land-surface datum, October 5, 1986.

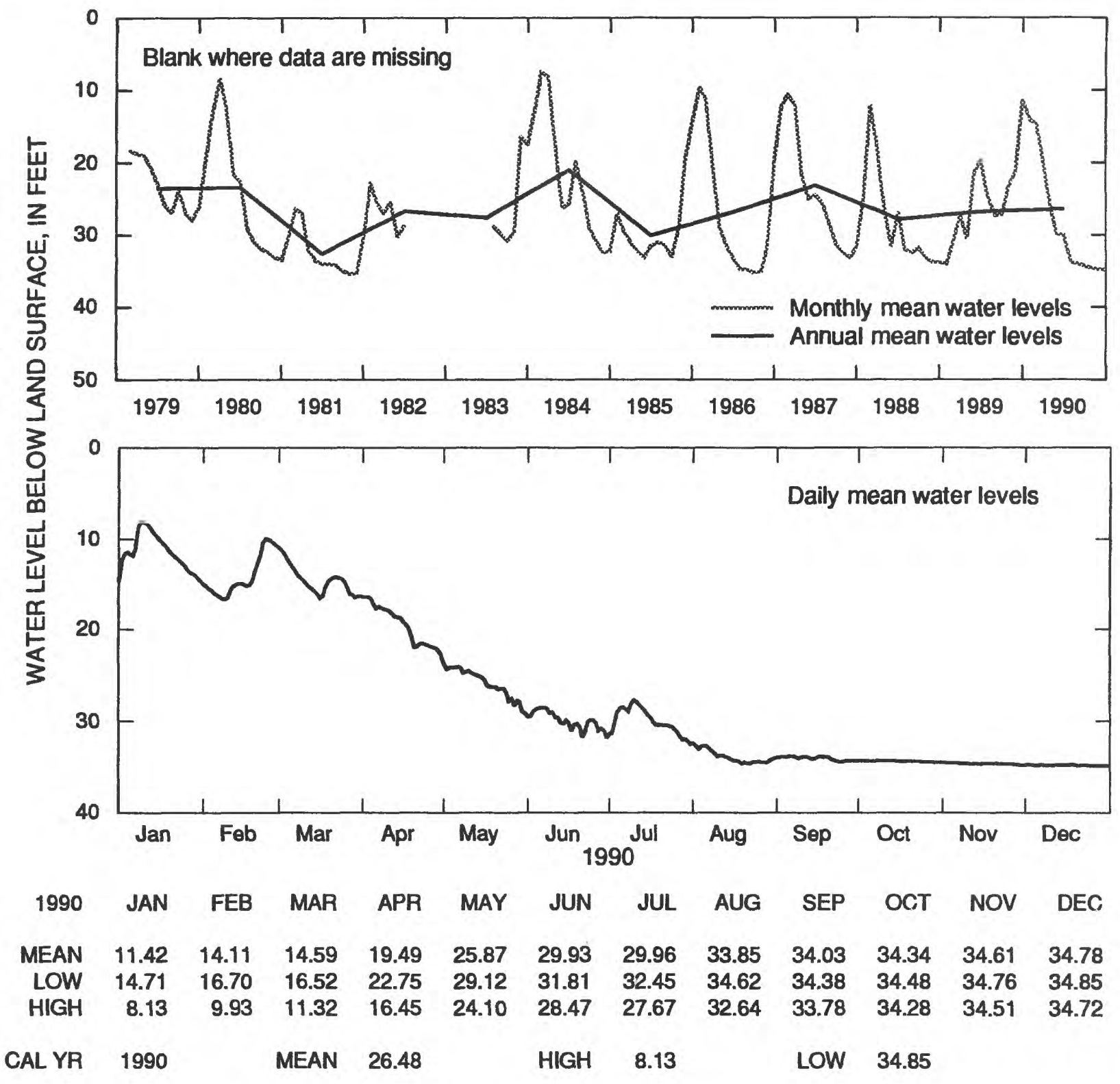

Figure 32.--Water level in observation well 06F001, Seminole County. 
313105084064302 Local number, $13 \mathrm{~L} 012$.

LOCATION.--Lat $31^{\circ} 31^{\prime} 05^{\prime \prime}$, long $84^{\circ} 06^{\circ} 43^{\prime \prime}$, Hydrologic Unit 03130008, about 6.5 mi southeast of Albany, east of U.S.

Highway 19 on dirt road, 0.1 mi north of School Bus Road.

Owner: U.S. Geological Survey, test well 3.

AQUIFER.--Upper Floridan aquifer.

WELL CHARACTERISTICS.--Drilled observation well, diameter 4 in., depth $218 \mathrm{ft}$, cased to $54 \mathrm{ft}$, open hole.

DATUM.--Altitude of land-surface datum is $195 \mathrm{ft}$.

Measuring point: Top of recorder shelf, $3.0 \mathrm{ft}$ above land-surface datum.

REMARKS.-Well pumped and redeveloped August 17, 1988. Water levels for period of missing record January 10-24, 1990, were estimated.

PERIOD OF RECORD.--June 1977 to current year.

EXTREMES FOR PERIOD OF RECORD.--Highest water level, $21.92 \mathrm{ft}$ below land-surface datum, March 2, 1979; lowest, $48.18 \mathrm{ft}$ below land-surface datum, July 1, 1981.

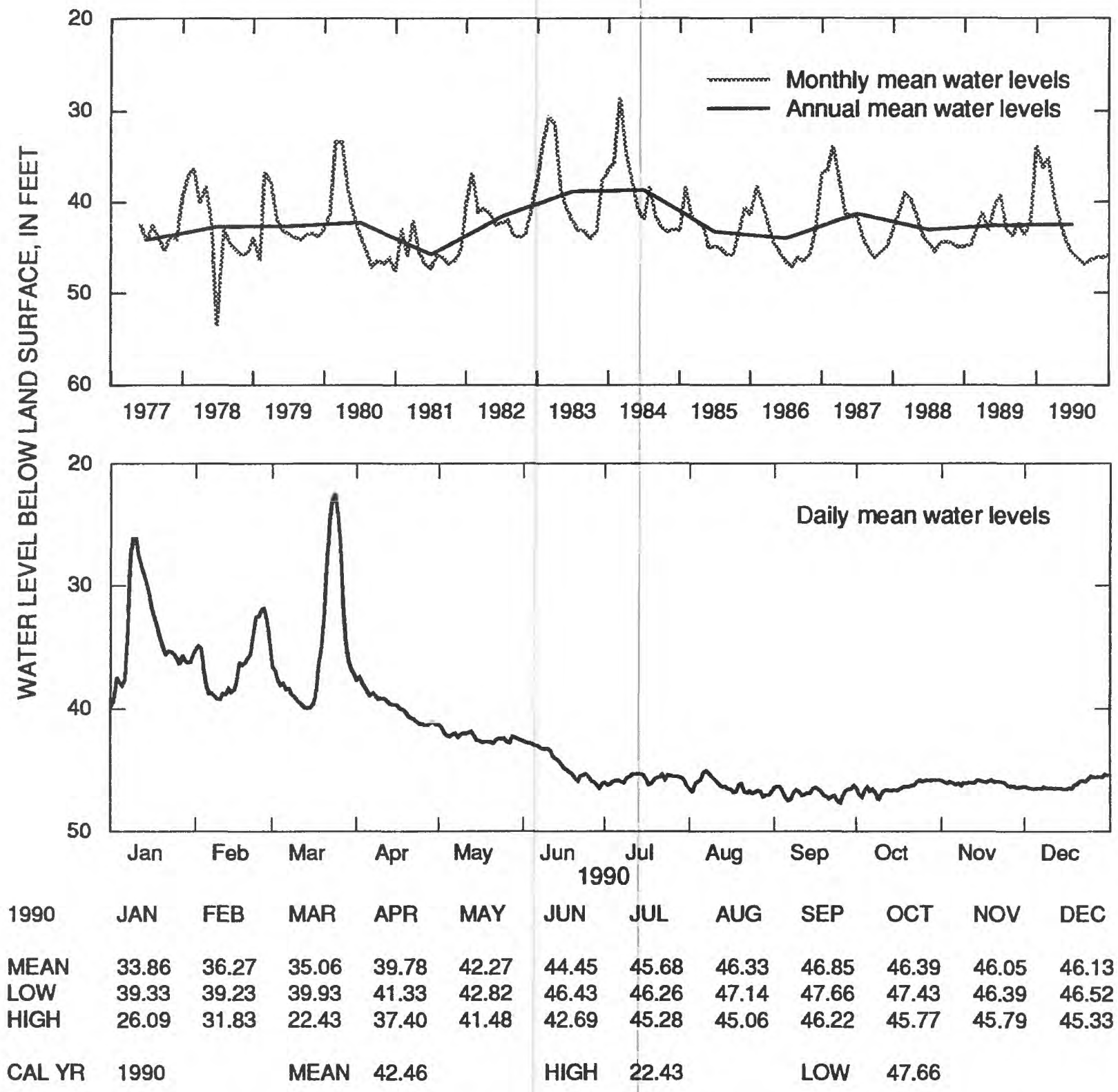

Figure 33.--Water level in observation well 13L012, Dougherty County. 
310507084262201 Local number, $10 \mathrm{G} 313$.

LOCATION.--Lat $31^{\circ} 05^{\prime} 07^{\prime \prime}$, long 84²6'22", Hydrologic Unit 03130008, $1.95 \mathrm{mi}$ west of Vada off Decatur-Mitchell County line road, $1.0 \mathrm{mi}$ north in pine tree farm.

Owner: Harvey Meinders.

AQUIFER.--Upper Floridan aquifer.

WELL CHARACTERISTICS.-Cable-tool, observation well, diameter 12 in., depth $250 \mathrm{ft}$, cased to $87 \mathrm{ft}$, open hole.

DATUM.--Altitude of land-surface datum is $145 \mathrm{ft}$.

Measuring point: Top of recorder shelf, $4.17 \mathrm{ft}$ above land-surface datum.

REMARKS.--None.

PERIOD OF RECORD.--November 1961 to September 1968; April 1976 to current year.

EXTREMES FOR PERIOD OF RECORD.--Highest water level, $32.98 \mathrm{ft}$ below land-surface datum, April 9, 1984; lowest, $60.26 \mathrm{ft}$ below land-surface datum, January 1, 1982.

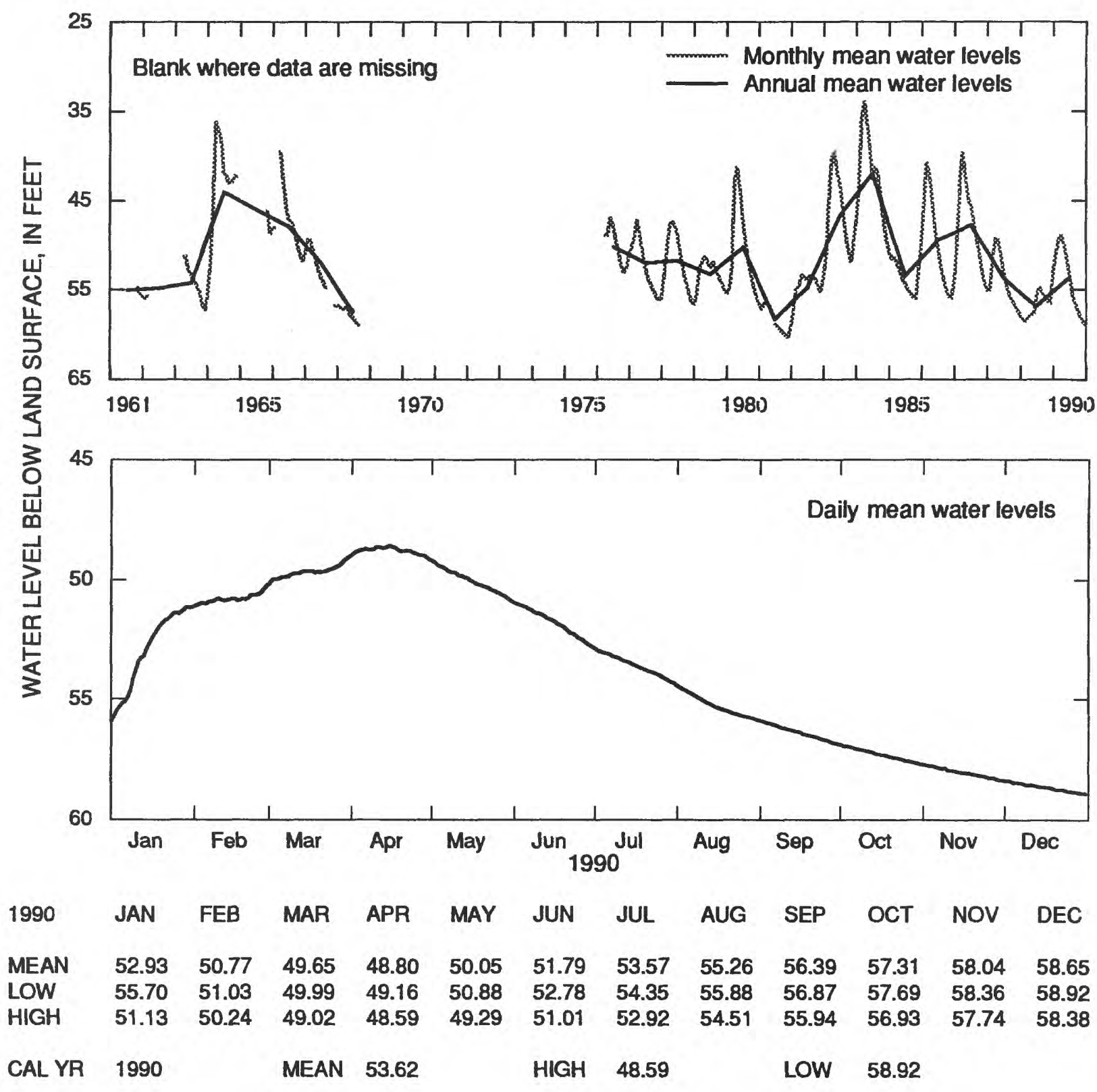

Figure 34.--Water level in observation well 10G313, Mitchell County. 
313748084002901 Local number, $13 \mathrm{~L} 003$.

LOCATION.--Lat $31^{\circ} 33^{\prime} 13^{\prime \prime}$, long $84^{\circ} 00^{\prime} 21^{\prime \prime}$, Hydrologic Unit 03130008 , near northeast corner of Marine Corps Supply

Center, in Acree.

Owner: City of Albany and Dougherty County.

AQUIFER---Upper Floridan aquifer.

WELL CHARACTERISTICS.--Drilled unused supply well, diameter 6 in., depth $259 \mathrm{ft}$, cased to $206 \mathrm{ft}$, open hole.

DATUM.--Altitude of land-surface datum is $225 \mathrm{ft}$.

Measuring point: Top of recorder shelf, $4.10 \mathrm{ft}$ above land-surface datum.

REMARKS.--Well pumped and sounded June 21, 1978; water-quality sample collected at conclusion of pumping.

Borehole geophysical survey conducted March 17, 1977.

PERIOD OF RECORD.--January 1963 to current year.

EXTREMES FOR PERIOD OF RECORD.--Highest water level, 17.41 ft below land-surface datum, April 2, 1965; lowest, $44.89 \mathrm{ft}$ below land-surface datum, December 13, 1981.

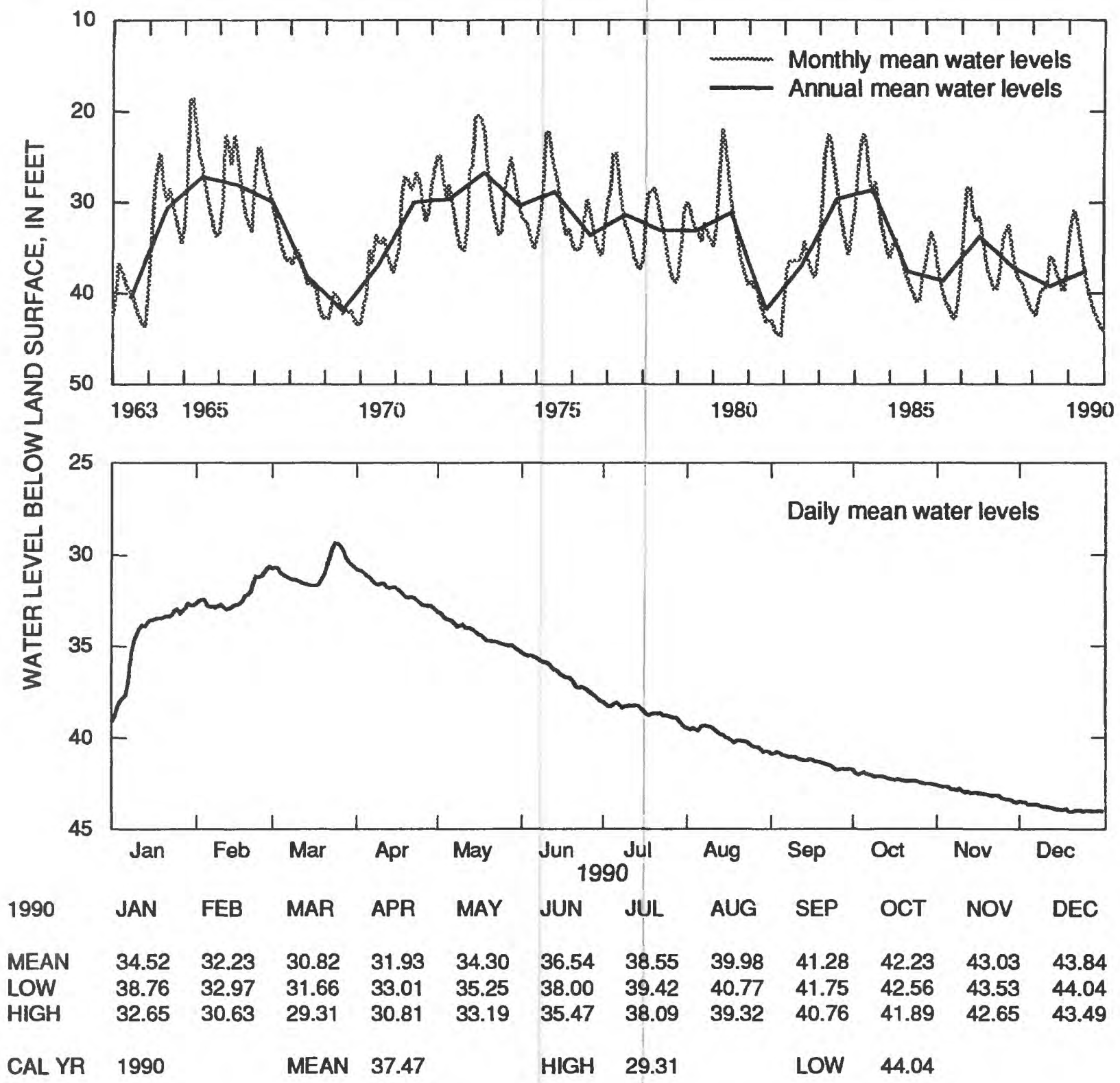

Figure 35.--Water level in observation well 13L003, Dougherty County. 
312127084065801 Local number, $13 \mathrm{~J} 004$.

LOCATION.-Lat $31^{\circ} 21^{\prime 2} 29^{\prime \prime}$, long $84^{\circ} 06^{\prime} 57^{\prime \prime}$, Hydrologic Unit 03130008, 2.7 mi north of intersection of U.S. Highway

19 and Georgia Highway 112, $0.7 \mathrm{mi}$ west of Stagecoach Road.

Owner: Aurora Dairy, Wright 1.

AQUIFER.--Upper Floridan aquifer.

WELL CHARACTERISTICS.--Drilled observation well, diameter $12 \mathrm{in}$., depth $208 \mathrm{ft}$, cased to $77 \mathrm{ft}$, open hole.

DATUM.--Altitude of land-surface datum is $200 \mathrm{ft}$.

Measuring point: Top of recorder shelf, $3.60 \mathrm{ft}$ above land-surface datum.

REMARKS.--None.

PERIOD OF RECORD.--June 1978 to current year.

EXTREMES FOR PERIOD OF RECORD.--Highest water level, $36.90 \mathrm{ft}$ below land-surface datum, April 13, 1980;

lowest, $54.05 \mathrm{ft}$ below land-surface datum, December 25, 1990.

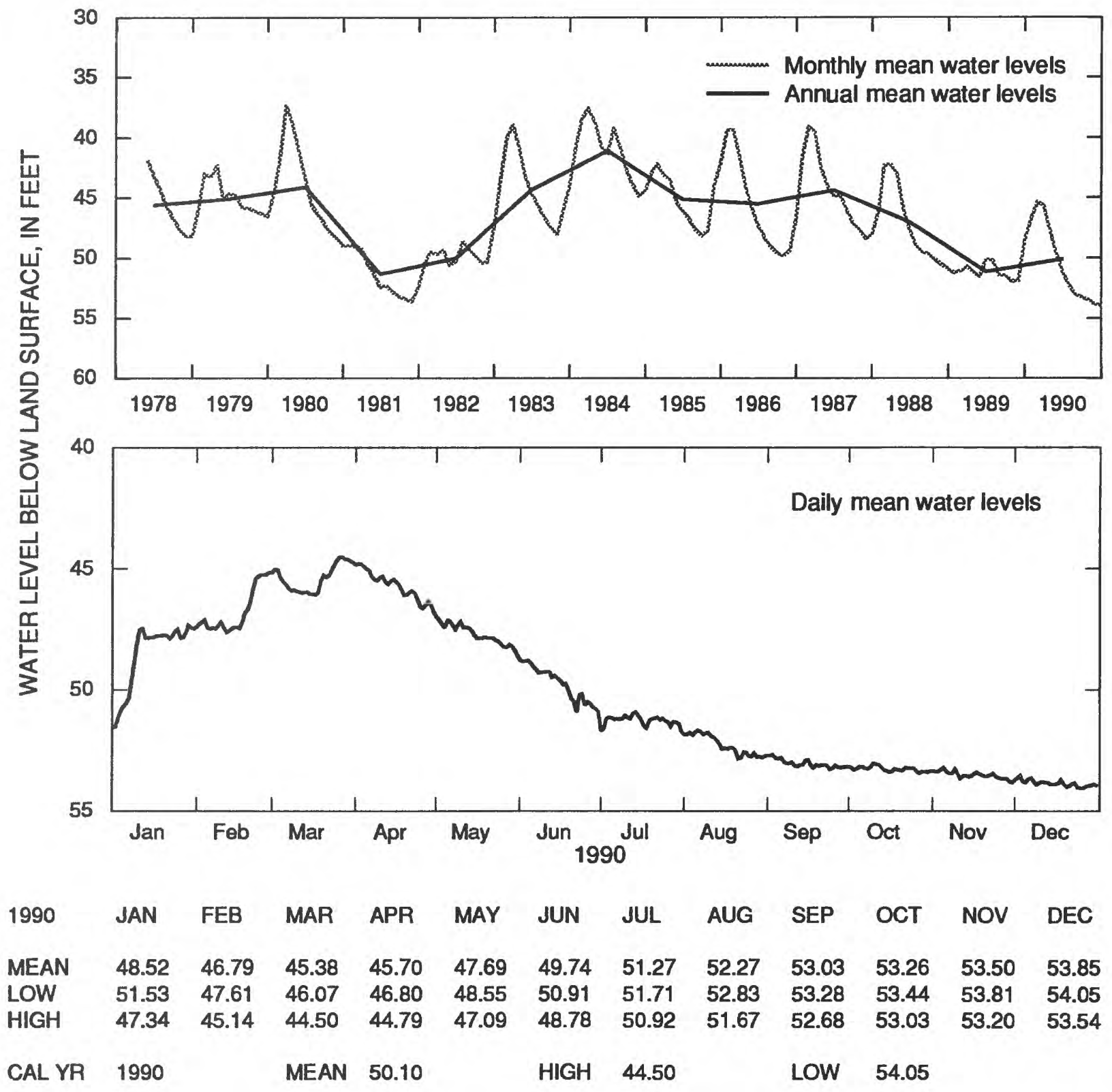

Figure 36.--Water level in observation well 13J004, Mitchell County. 
313146083491601 Local number, 15L020.

LOCATION.--Lat $31^{\circ} 31^{\prime} 46^{\prime \prime}$, long $83^{\circ} 49^{\prime} 16^{\prime \prime}$, Hydrologic Unit 03110204, near water tank, behind the VFW on U.S. Highway 82 east, Sylvester.

Owner: City of Sylvester.

AQUIFER.--Upper Floridan aquifer.

WELL CHARACTERISTICS.--Drilled unused municipal well, diameter 18 in., depth $450 \mathrm{ft}$, cased to $212 \mathrm{ft}$, open hole.

DATUM.--Altitude of land-surface datum is $420 \mathrm{ft}$.

Measuring point: Top of recorder shelf, $2.90 \mathrm{ft}$ above land-surface datum.

REMARKS.--Well pumped and sounded July 19, 1978. Borehole geophysical survey conducted June 5, 1975.

PERIOD OF RECORD.--May 1972 to current year.

EXTREMES FOR PERIOD OF RECORD.--Highest water level, $191.5 \mathrm{ft}$ below land-surface datum, May 17, 1973; lowest, $205.88 \mathrm{ft}$ below land-surface datum, August 20, 1990.

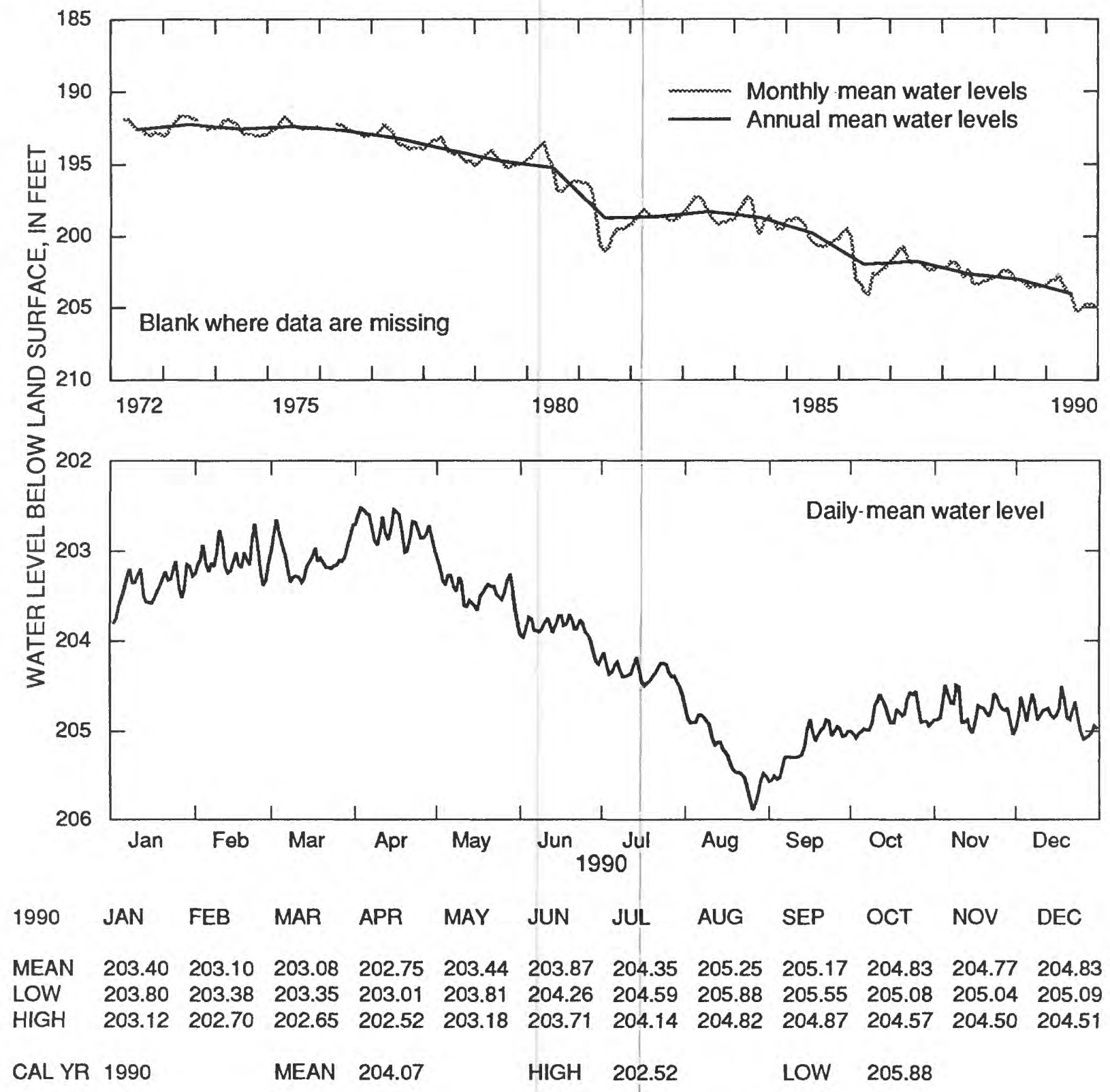

Figure 37.--Water level in observation well 15L020, Worth County. 


\section{South-central area}

The water level in the Upper Floridan aquifer in south-central Georgia is monitored in six wells, four of which are summarized in this report (fig. 27). Water levels in wells tapping the aquifer in this area are affected by variations in precipitation, evapotranspiration, and to a lesser degree, pumping (Krause, 1979). In the Valdosta area, water levels also are affected by streamflow (Krause, 1979). The water level generally is highest following the winter and spring rainy seasons, and lowest in the fall. During 1987, an estimated 79 $\mathrm{Mgal} / \mathrm{d}$ were withdrawn from aquifers in south-central Georgia (Trent and others, 1990), primarily from the Upper Floridan aquifer. Of this amount, about $6 \mathrm{Mgal} / \mathrm{d}$ were withdrawn in the Valdosta area.

The annual mean water levels in well $18 \mathrm{~K} 049$ in Tift County (fig. 38) and in well $18 \mathrm{H} 016$ in Cook County (fig. 39) were about 2.5 and about $1.2 \mathrm{ft}$ lower in 1990 than in 1989, respectively. A general trend of declining water levels in the Upper Floridan aquifer has been observed since 1984 at well $18 \mathrm{~K} 049$ (fig. 38) and 1987 at well $18 \mathrm{H} 016$ (fig. 39). Record-low daily mean water levels were recorded in wells $18 \mathrm{~K} 049$ (fig. 38) and $18 \mathrm{H} 016$ (fig. 39) in August and October 1990, respectively, that were about 4.6 and about $1.6 \mathrm{ft}$ lower than the previous record lows.

During October 1990, water levels were measured in 89 wells in the Valdosta area, and a water-level map was constructed (Burgoon, 1991) (fig. 40). Most water levels used in preparing this map were the lowest ever measured in the Valdosta area. Reduced recharge to the Upper Floridan aquifer caused by below normal rainfall (see the precipitation graph for Albany, fig. 5) resulted in substantial water-level declines. In addition, pumping from the Upper Floridan aquifer resulted in the formation of cones of depression around pumping centers at Valdosta and Moody Air Force Base. Other depressions in the water surface, such as those northwest of Valdosta and at Bemiss, appear to be anomalous and may have developed as a result of the influence of buried karst terrain and the record-low, ground-water levels.

The Upper Floridan aquifer receives recharge from the Withlacoochee River north of Valdosta where water from the river flows directly into sinkholes and large solution openings in the aquifer (Krause, 1979). In this area, increased precipitation and streamflow in winter and early spring result in high ground-water levels. During most years, decreased precipitation and increased evapotranspiration in the summer results in low streamflow and correspondingly low water levels. This relation is illustrated on the hydrographs for wells 19E009 (fig. 41) and 19F039 (fig. 42), where the annual mean water levels were about 5.6 and $8.2 \mathrm{ft}$ lower in 1990 than in 1989, respectively. Record-low daily mean water levels were recorded in wells 19E009 (fig. 41) and 19F039 (fig. 42) during September and October that were about 5.2 and $5.6 \mathrm{ft}$ lower than previous record lows, respectively. Although there was a water-level decline during $1989-90$, there is no apparent long-term waterlevel trend in either well. 
312712082593301 Local number, $18 \mathrm{~K} 049$.

LOCATION.--Lat 31 27'12", long 82 59'33", Hydrologic Unit 03110203, near the intersection of Goff Street and Ferry

Lake Road, at city of Tifton Maintenance and Water Works, on east side of Tifton.

Owner: U.S. Geological Survey, test well 1.

AQUIFER.--Upper Floridan aquifer.

WELL CHARACTERISTICS.--Drilled observation well, diameter 6 in., depth $620 \mathrm{ft}$, cased to $270 \mathrm{ft}$, open hole.

DATUM.-Altitude of land-surface datum is $330 \mathrm{ft}$.

Measuring point: Top of recorder shelf, $3.0 \mathrm{ft}$ above land-surface datum.

REMARKS.-Borehole geophysical survey conducted March 18, 1978.

PERIOD OF RECORD.--March 28, 1978, to current year.

EXTREMES FOR PERIOD OF RECORD.--Highest water level, $102.70 \mathrm{ft}$ below land-surface datum, May 14, 1978; lowest,

$126.23 \mathrm{ft}$ below land-surface datum, August 26, 1990.

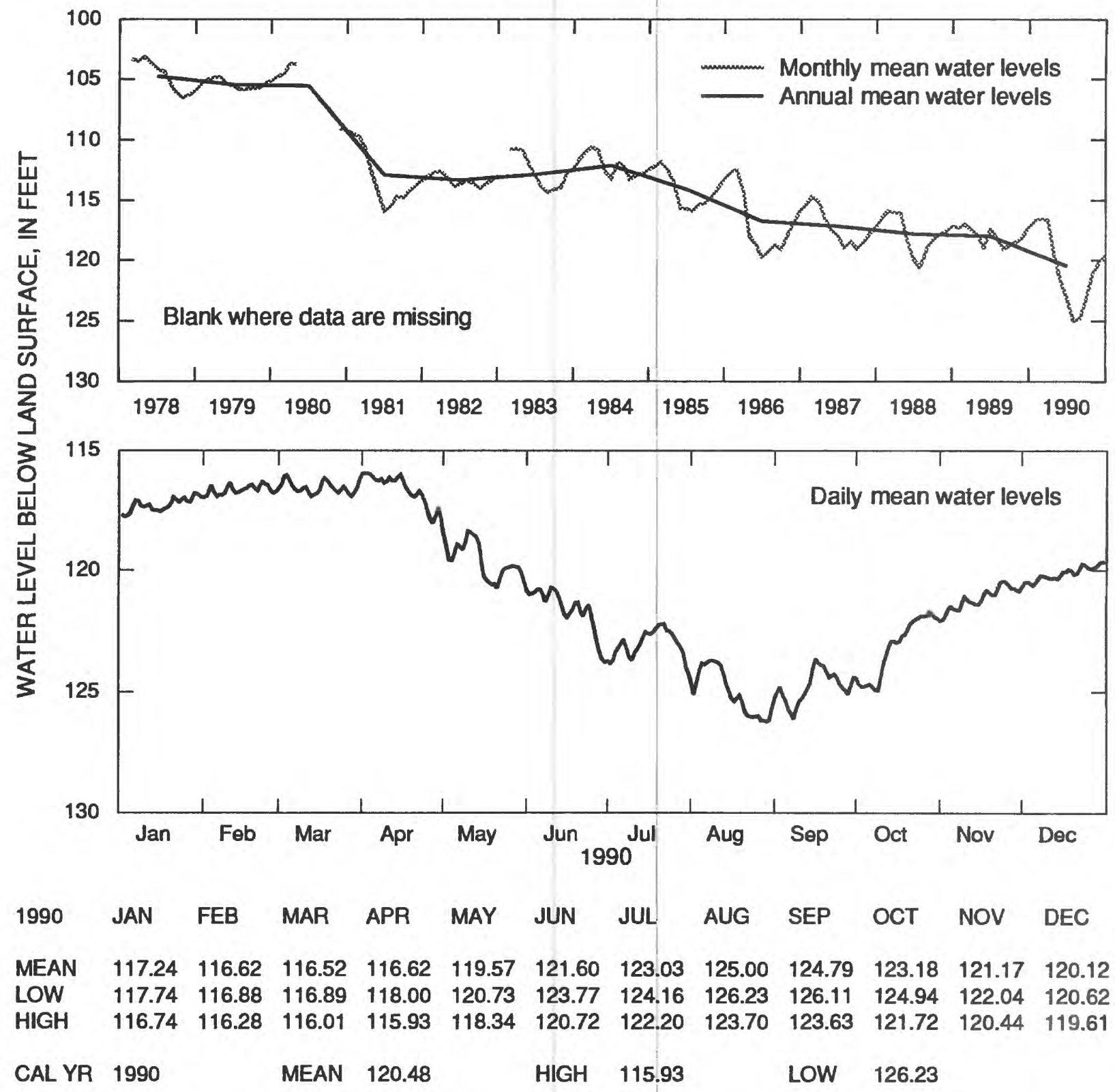

Figure 38.--Water level in observation well 18K049, Tift County. 
310813083260301 Local number, $18 \mathrm{H016}$.

LOCATION.-Lat $31^{\circ} 08^{\prime} 13^{\prime \prime}$, long $83^{\circ} 26^{\prime} 03^{\prime \prime}$, Hydrologic Unit 03110203 , on west side of the intersection of Second

Street and North Elm Street, 0.3 mi north of intersection of Georgia Highways 76 and 37, in Adel.

Owner: U.S. Geological Survey, Adel test well.

AQUIFER.--Upper Floridan aquifer.

WELL CHARACTERISTICS.--Drilled observation well, diameter 8 in., depth $865 \mathrm{ft}$, cased to $207 \mathrm{ft}$, open hole.

DATUM.--Altitude of land-surface datum is $241 \mathrm{ft}$.

Measuring point: Top of recorder shelf, $2.66 \mathrm{ft}$ above land-surface datum.

REMARKS.--Well pumped July 19, 1978; water-quality sample collected at conclusion of pumping. Borehole geo-

physical survey conducted October 24, 1974.

PERIOD OF RECORD.--December 1964 to current year.

EXTREMES FOR PERIOD OF RECORD.--Highest water level, $163.34 \mathrm{ft}$ below land-surface datum, July 5, 1966; lowest,

$177.39 \mathrm{ft}$ below land-surface datum, October 8, 1990.

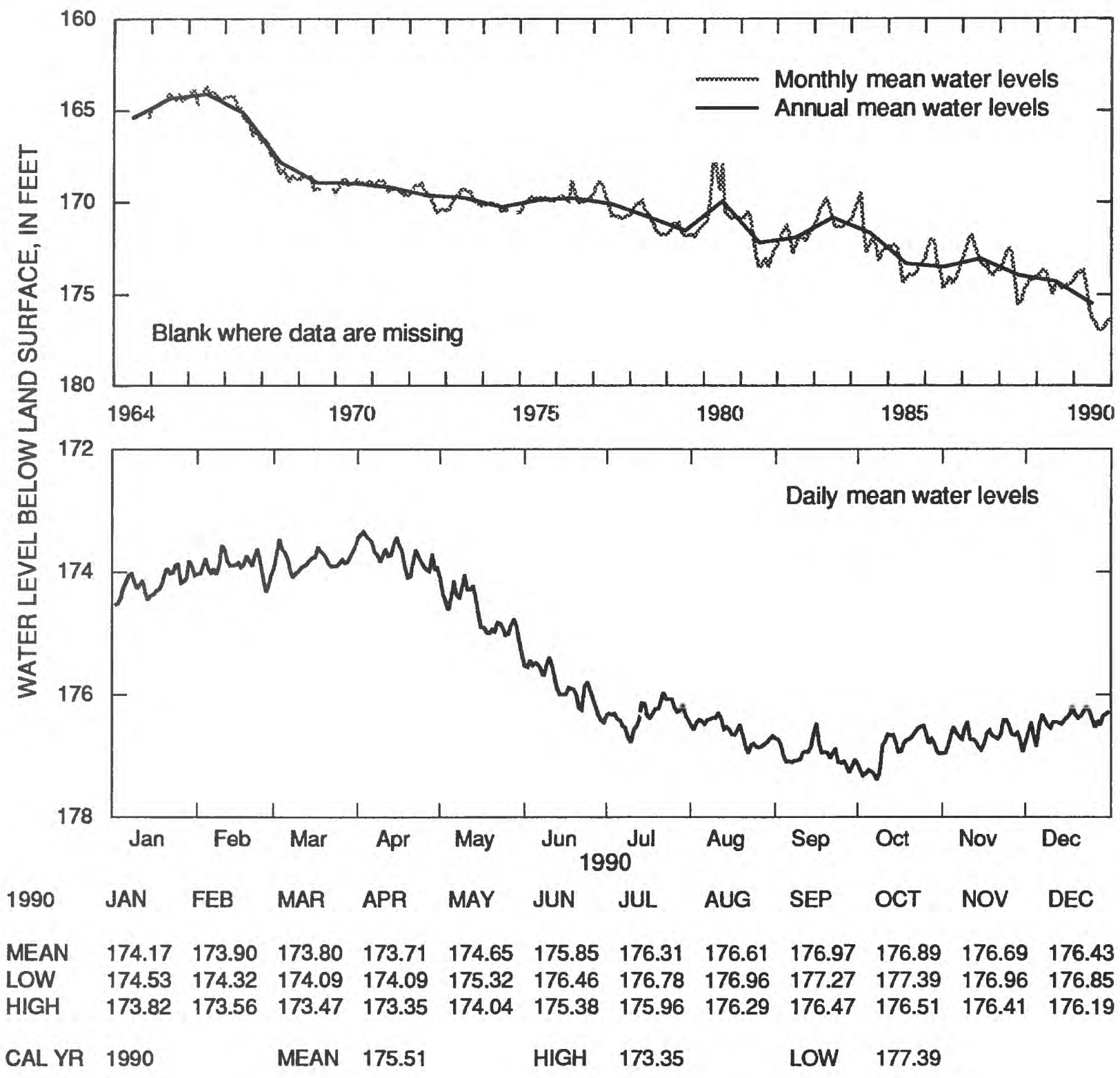

Figure 39.--Water level in observation well 18H016, Cook County. 


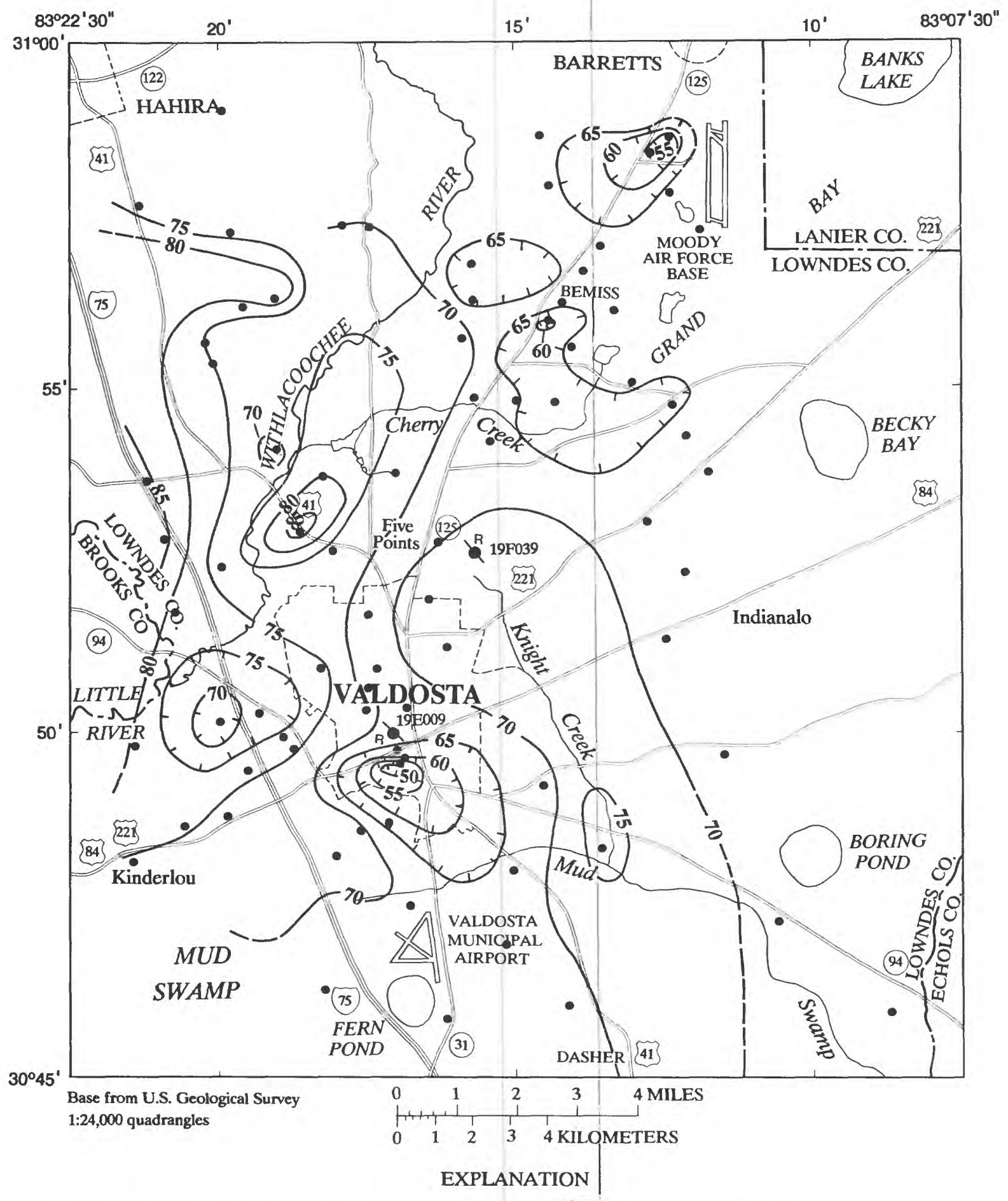

-70-- WATER-LEVEL CONTOUR--Shows altitude at which water level would have stood in tightly cased wells. Dashed where approximately located. Hachures indicate depressions. Contour interval 5 feet.

Datum is sea level
$\mathrm{R}^{19 \mathrm{EO} 09}$ OBSERVATION WELL AND IDENTIFICATION NUMBER--Equipped with recorder, hydrograph included in this report

IDATA POINT

Figure 40.--Water level and locations of observation wells completed in the Upper Floridan aquifer in the Valdosta area, October 1990. From Burgoon (1991). 
304949083165301 Local number, $19 \mathrm{E} 009$.

LOCATION.-Lat $30^{\circ} 49^{\prime} 51^{\prime \prime}$, long $83^{\circ} 166^{\prime \prime} 8^{\prime \prime}$, Hydrologic Unit 03110202, N. Oak Street, one block north of intersection with U.S. Highway 84, Valdosta.

Owner: City of Valdosta.

AQUIFER.--Upper Floridan aquifer.

WELL CHARACTERISTICS.--Drilled unused municipal supply well, diameter 20 in., depth $342 \mathrm{ft}$, cased to $200 \mathrm{ft}$, open hole.

DATUM.--Altitude of land-surface datum is $217 \mathrm{ft}$.

Measuring point: Top of casing, $1.7 \mathrm{ft}$ above land-surface datum.

REMARKS.-Well pumped July 18, 1978; water-quality sample collected at conclusion of pumping. Borehole geophysical survey conducted April 11, 1963. Water levels for period of missing record, March 14-27, 1990, were estimated.

PERIOD OF RECORD.--February 1957 to current year.

EXTREMES FOR PERIOD OF RECORD.--Highest water level, $112.69 \mathrm{ft}$ below land-surface datum, March 9, 1964; lowest,

$151.79 \mathrm{ft}$ below land-surface datum, September 19, 1990.

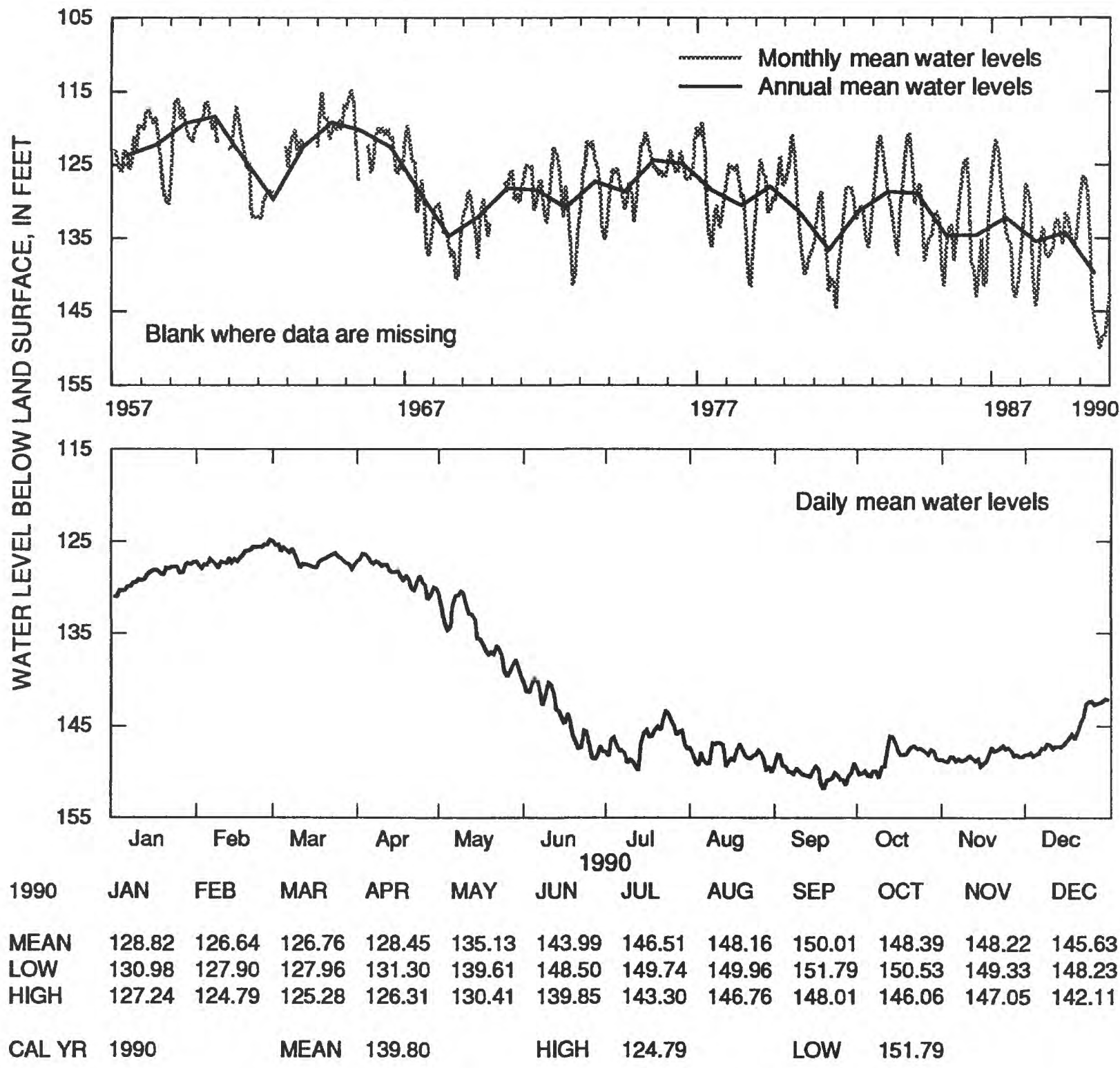

Figure 41.--Water level in observation well 19E009, Lowndes County. 
305241083154401 Local number, $19 \mathrm{~F} 039$.

LOCATION.--Lat $30^{\circ} 52^{\prime} 41^{\prime \prime}$, long $83^{\circ} 15^{\circ} 46^{\prime \prime}$, Hydrologic Unit 03110203, at water tank by Valdosta High School.

Owner: City of Valdosta, well 8.

AQUIFER.--Upper Floridan aquifer.

WELL CHARACTERISTICS.--Drilled unused municipal supply well, diameter $16 \mathrm{in}$., depth $450 \mathrm{ft}$, cased to $350 \mathrm{ft}$, open hole.

DATUM.-Altitude of land-surface datum is $222 \mathrm{ft}$.

Measuring point: Pump base, $1.40 \mathrm{ft}$ above land-surface datum.

REMARKS.-None.

PERIOD OF RECORD.--February 1979 to current year.

EXTREMES FOR PERIOD OF RECORD.--Highest water level, $114.28 \mathrm{ft}$ below land-surface datum, April 9, 1984; lowest,

$151.28 \mathrm{ft}$ below land-surface datum, October 9, 1990.

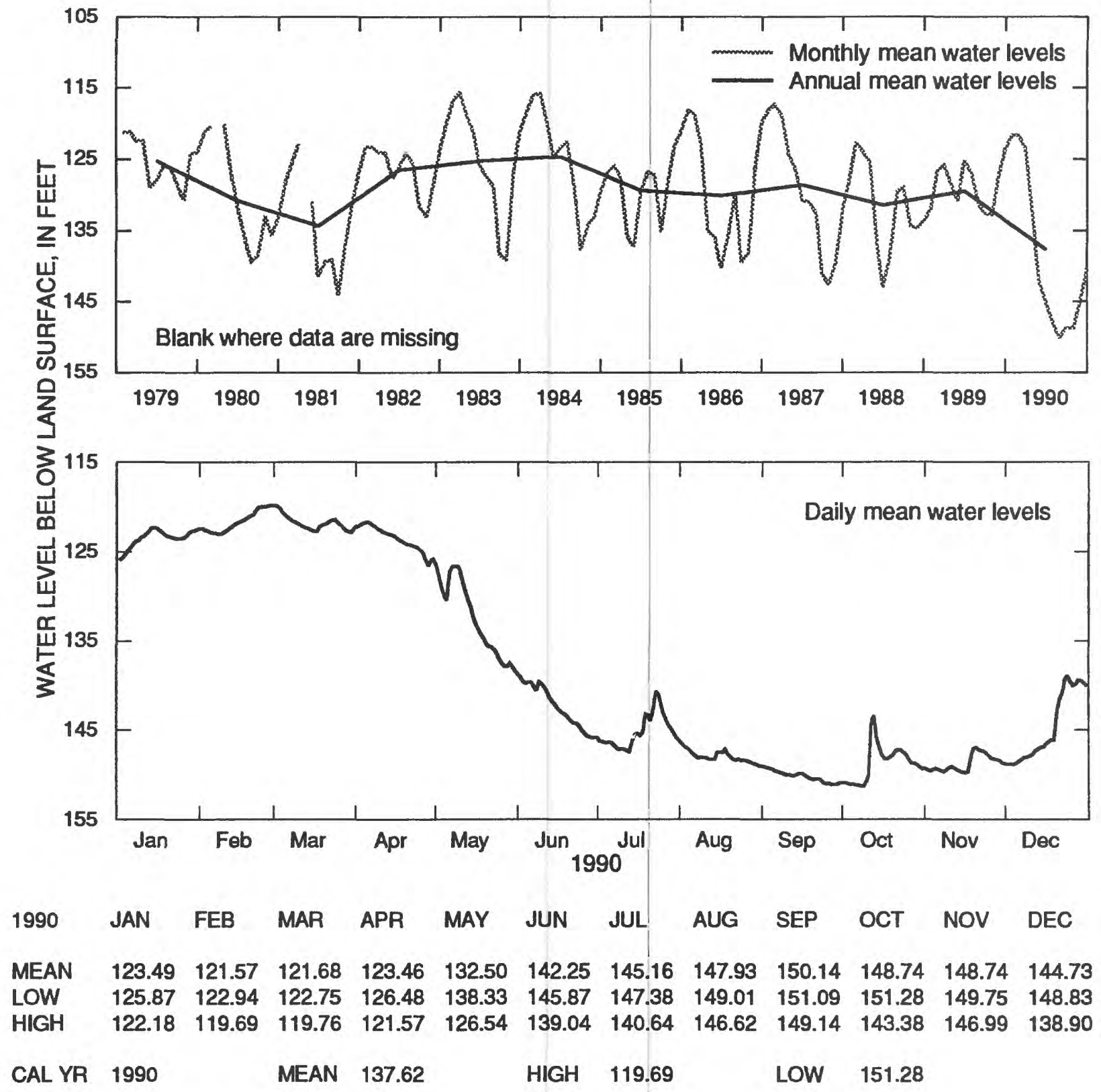

Figure 42.--Water level in observation well 19F039, Lowndes County. 
The water level in the Upper Floridan aquifer in east-central Georgia is monitored in three wells, all of which are summarized in this report (fig. 27). During 1987, an estimated $16 \mathrm{Mgal} / \mathrm{d}$ of water were withdrawn from aquifers in this area (Trent and others,1990), primarily from the Upper Floridan aquifer. Well 21T001 (fig. 43) in Laurens County is near the recharge area for the Upper Floridan aquifer, and the water level in this well responds primarily to seasonal fluctuations in precipitation (compare fig. 43 with the precipitation graph for Macon, fig. 10). The annual mean water level in well 21T001 (fig. 43) was about $0.6 \mathrm{ft}$ lower in 1990 than in 1989. Although there was a water-level decline during 1989-90, there is not an apparent long-term trend in the water level in this well.

In Montgomery and Toombs Counties, the water level in the Upper Floridan aquifer is affected primarily by variations in local and regional pumping. This response is shown on the hydrographs for well 250001 in Montgomery County (fig. 44) and well 26R001 in Toombs County (fig. 45). The 1990 annual mean water level in wells $25 \mathrm{Q} 001$ (fig. 44) and 26R001 (fig. 45) was about 0.9 and about $1.4 \mathrm{ft}$ lower, respectively, than in 1989, reversing the slight upward trend in water levels that began in 1988. A record-low daily mean water level was recorded in well $25 \mathrm{Q} 001$ (fig. 44) in October that was about $0.7 \mathrm{ft}$ lower than the previous record low. 
322652083033001 Local number, 21 T001.

LOCATION.--Lat 32 $27^{\prime} 06^{\prime \prime}$, long 83 $03^{\prime 2} 28^{\prime \prime}$, Hydrologic Unit 03070102, 1.0 mi east of Georgia Highway 338 on dirt road,

$1.5 \mathrm{mi}$ northwest of Dexter.

Owner: Danny Hogan.

AQUIFER.-Upper Floridan aquifer.

WELL CHARACTERISTICS.--Drilled unused supply well, diameter 4 in, depth $123 \mathrm{ft}$, cased to $89 \mathrm{ft}$, open hole.

DATUM.-Altitude of land-surface datum is $259 \mathrm{ft}$.

Measuring point: Top of recorder shelf, $2.57 \mathrm{ft}$ above land-surface datum.

REMARKS.--Borehole geophysical survey conducted November 1973. Water levels for period of missing record,

February 17-28, were estimated.

PERIOD OF RECORD.--March 1964 to current year.

EXTREMES FOR PERIOD OF RECORD.--Highest water level, $23.62 \mathrm{ft}$ below land-surface datum, January 26, 1987; lowest,

$39.58 \mathrm{ft}$ below land-surface datum, November 12, 1968.

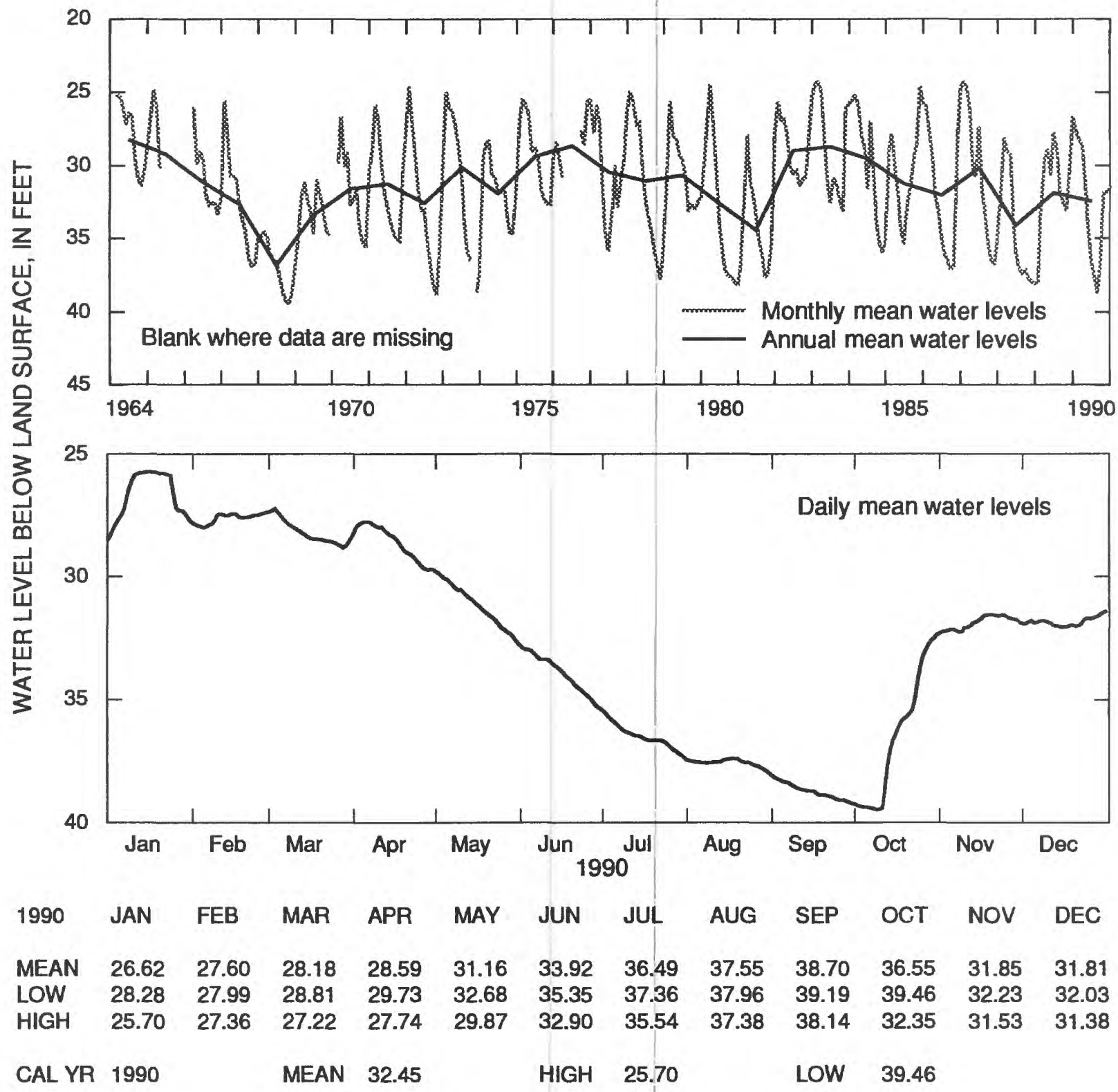

Figure 43.--Water level in observation well 21T001, Laurens County. 
320226082301101 Local number, $25 \mathrm{Q} 001$.

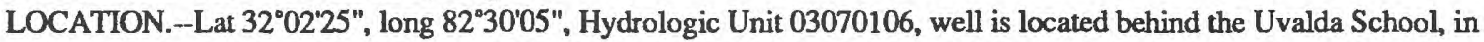
Uvalda.

Owner: Montgomery County Board of Education.

AQUIFER.--Upper Floridan aquifer.

WELL CHARACTERISTICS.--Drilled unused supply well, diameter $6 \mathrm{in}$., depth $536 \mathrm{ft}$, cased to $421 \mathrm{ft}$, open hole.

DATUM.--Altitude of land-surface datum is $190 \mathrm{ft}$.

Measuring point: Top of 6 in. casing at land-surface.

REMARKS.--Borehole geophysical survey conducted April 22, 1966.

PERIOD OF RECORD.--June 1966 to current year.

EXTREMES FOR PERIOD OF RECORD.--Highest water level, $64.13 \mathrm{ft}$ below land-surface datum, June 10, 1966; lowest,

$82.94 \mathrm{ft}$ below land-surface datum, October 7, 1990.

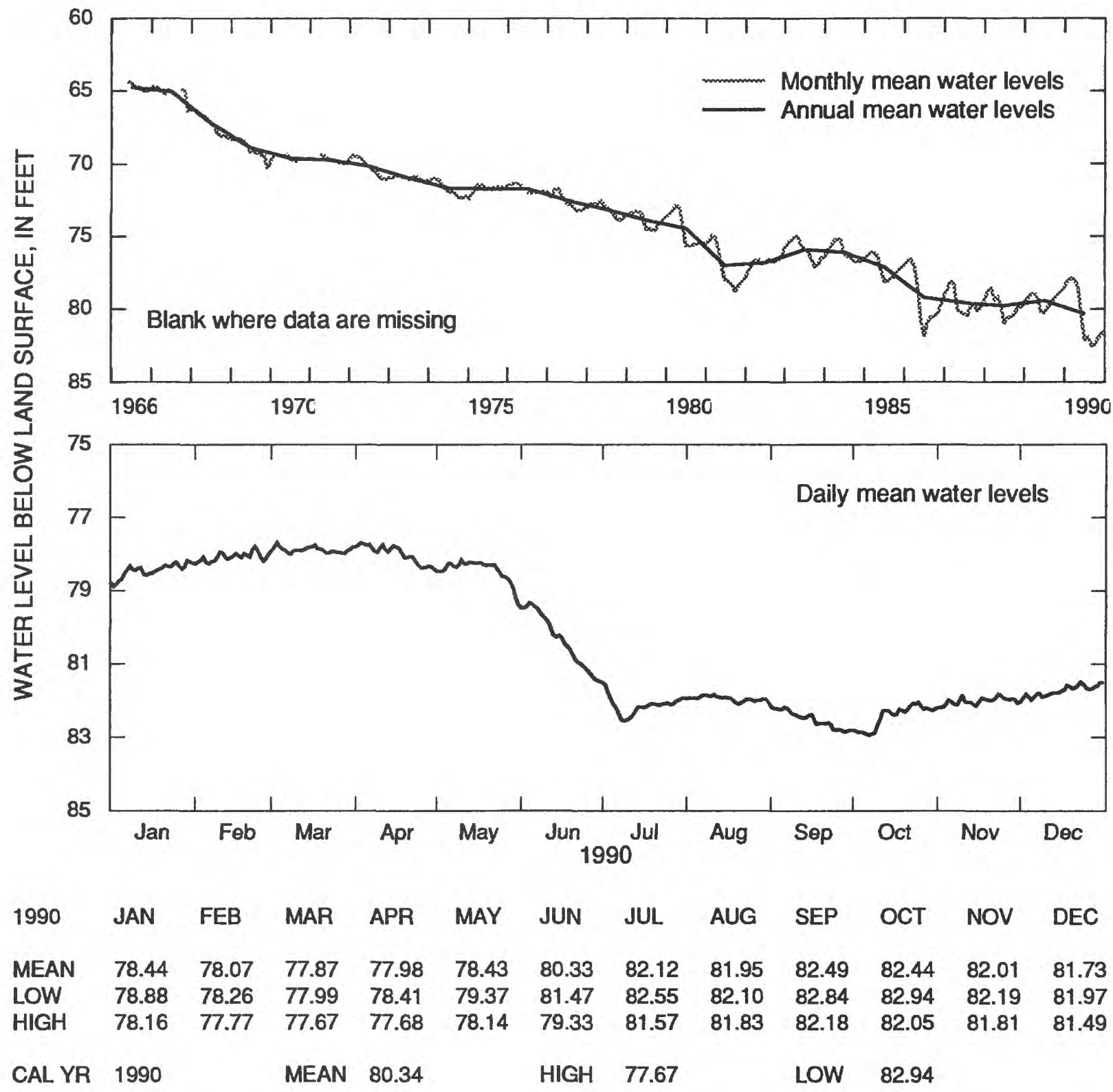

Figure 44.--Water level in observation well 25Q001, Montgomery County. 
321302082243601 Local number, $26 \mathrm{R} 001$.

LOCATION.-Lat $32^{\circ} 13^{\prime} 02^{\prime \prime}$, long $82^{\circ} 24^{\prime} 36^{\prime \prime}$, Hydrologic Unit $03070107,15 \mathrm{ft}$ south of the Vidalia Water and Street Department and Fire Station.

Owner: City of Vidalia, well 2.

AQUIFER.--Upper Floridan aquifer.

WELL CHARACTERISTICS.--Drilled municipal supply well, diameter 12 in., depth 1,000 ft, cased to $720 \mathrm{ft}$, open hole.

DATUM--Altitude of land-surface datum is $285 \mathrm{ft}$.

Measuring point: Top of 12 in. casing.

REMARKS.--Water levels for periods of missing record of June 19 to July 16, were estimated.

PERIOD OF RECORD.--April 1974 to current

EXTREMES FOR PERIOD OF RECORD.--Highest water level, $151.64 \mathrm{ft}$ below land-surface datum, April 15, 1974; lowest, $171.94 \mathrm{ft}$ below land-surface datum, July 10, 1986.

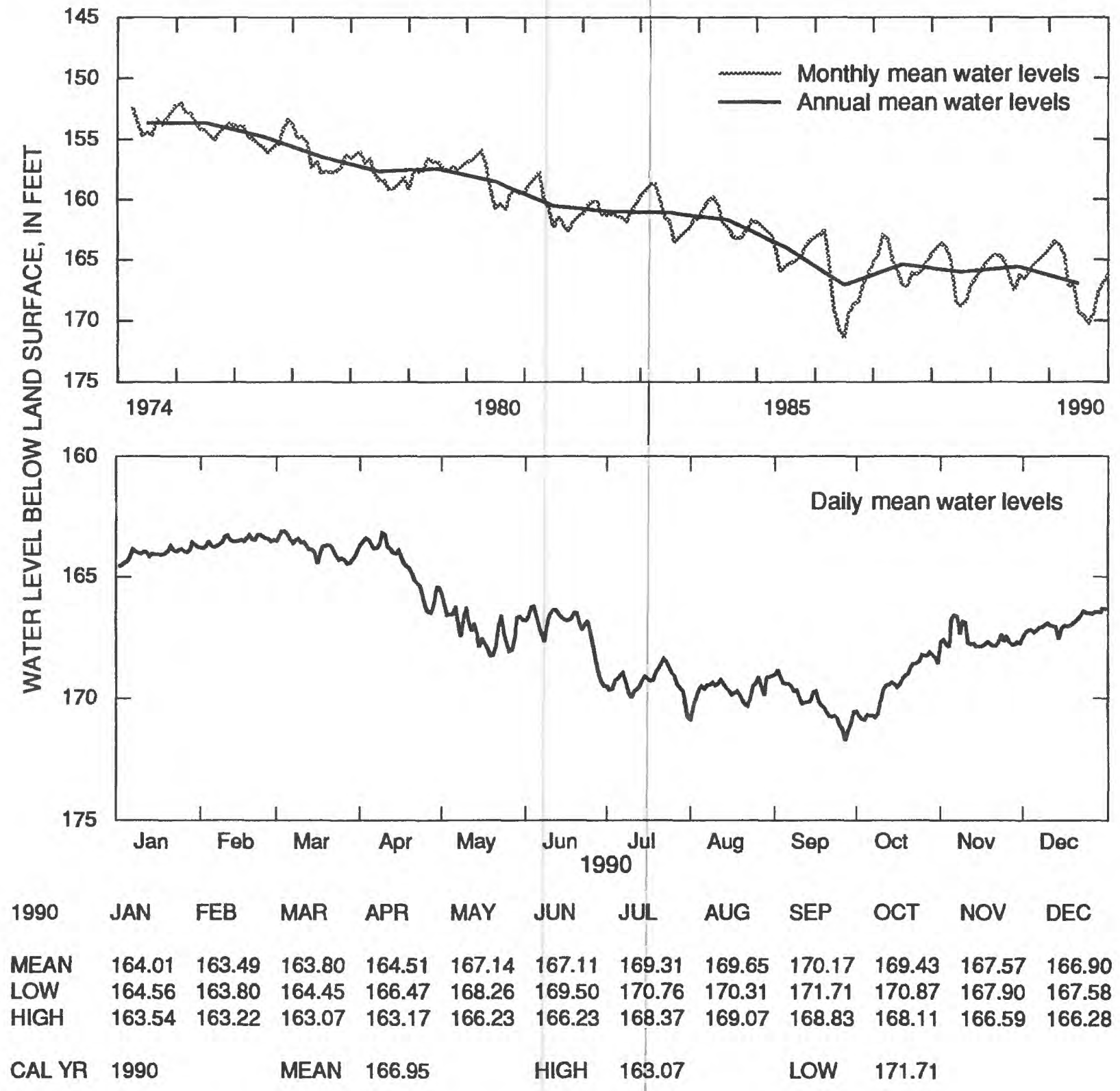

Figure 45.--Water level in observation well 26R001, Toombs County. 


\section{Coastal area}

The water level in the Upper Floridan aquifer in the coastal area is monitored in 22 wells, 15 of which are summarized in this report (fig. 46). Because the Upper Floridan aquifer in this area is deeply buried and far from the outcrop area, the ground-water level is influenced primarily by pumping and not by recharge from local precipitation (Clarke and others, 1990).

In this area and adjacent parts of Florida and South Carolina, the water-level surface of the Upper Floridan aquifer (fig. 28) is characterized by cones of depression that are caused by large ground-water withdrawal, primarily in the Savannah, Doctortown, Brunswick, and St Marys, Ga.-Fernandina Beach, Fla., areas. Pumpage in the coastal area of Georgia in 1987 was about $321 \mathrm{Mgal} / \mathrm{d}$, about 69 percent of which was used for industrial purposes (Trent and others, 1990). In the coastal area of Georgia, nearly all the groundwater withdrawal is from the Upper Floridan aquifer. In this report, the coastal area is divided into the following four subareas on the basis of major pumping centers (1) the Savannah subarea, (2) the JesupDoctortown subarea, (3) the Brunswick subarea, and (4) the St Marys-Okefenokee Swamp subarea (fig. 46). Within a given subarea, hydrographs for wells show similar water-level changes in response to variations in pumping. Industrial shutdowns, during which the amount of ground water withdrawn is greatly reduced, can be seen on hydrographs from wells located in the same hydrologic subarea, as sharp rises in water levels (see figs. $52,55,56,58$, and 59). 


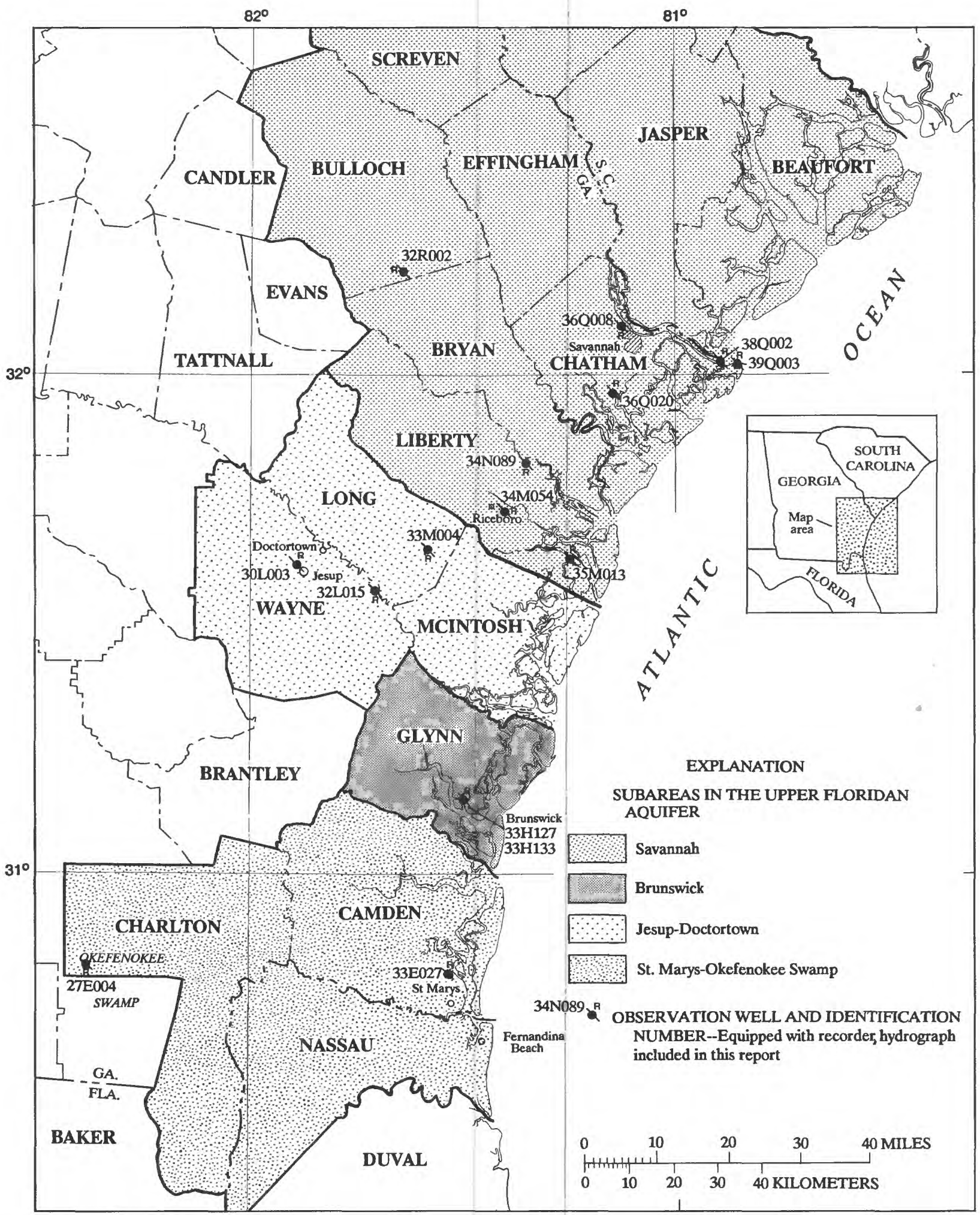

Base from U.S. Geological Survey State base maps

Figure 46.--Subareas and locations of observation wells completed in the Upper Floridan aquifer in the coastal area. 
The water level in the Upper Floridan aquifer in the Savannah subarea is monitored in 11 wells, 8 of which are summarized in this report (fig. 46). In this subarea, the water level in the Upper Floridan aquifer primarily is affected by pumping for municipal and industrial uses. As a result of this pumping, a cone of depression has developed in the water-level surface at Savannah (fig. 28). In 1987, withdrawal from the Floridan aquifer system exceeded $78 \mathrm{Mgal} / \mathrm{d}$ in the Savannah area and about $16 \mathrm{Mgal} / \mathrm{d}$ in the Riceboro area (Trent and others, 1990).

Hydrographs for observation wells near the center of pumping in Savannah, and in outlying areas, illustrate the effects of pumping on the ground-water levels. The 1990 annual mean water levels in wells $36 \mathrm{Q} 008$ (fig. 47), 36Q020 (fig. 48), 38Q002 (fig. 49), and 390003 (fig. 50) in the area of the cone of depression at Savannah were from about 0.7 to about $3.0 \mathrm{ft}$ lower than in 1989, continuing water-level declines that began in 1987 in wells 360008 (fig. 47), 360020 (fig. 47), and 38Q002 (fig. 49); and in 1983 in well 390003 (fig. 50). Water-level declines in these wells may be attributed to increased regional pumping as a result of below-normal precipitation during much of the year (see precipitation graph for Savannah, fig. 11). Observation well 32R002 (fig. 51), in Bulloch County northwest of the pumping center at Savannah, shows less response to variations in pumping at Savannah than do those wells in the area of the cone of depression. During 1990, the annual mean water level in well 32R002 (fig. 51) was about $1.7 \mathrm{ft}$ lower than in 1989, continuing a downward trend that began in 1987.

Observation wells 34M054 (fig. 52) and 34N089 (fig. 53) in Long County, and well 35M013 (fig. 54) in McIntosh County, show response to industrial pumping in the Riceboro and Savannah areas. The effect of an industrial shutdown at Riceboro in July 1990 can be seen on the hydrographs for the three wells. The 1990 annual mean water levels in these wells were from about $1.9 \mathrm{ft}$ to about $2.8 \mathrm{ft}$ lower than in 1989, continuing downward trends that began in 1983. Record-low, daily mean water levels were recorded in all three wells during October and November 1990 that were from about 3.3 to $4.8 \mathrm{ft}$ lower than the previous record lows. 
320530081085001 Local number, 36Q008.

LOCATION.--Lat $32^{\circ} 05^{\prime} 30^{\prime \prime}$, long $81^{\circ} 08^{\prime} 50^{\prime \prime}$, Hydrologic Unit $03060204,0.19$ mi southeast of intersection of Alfred Street and U.S. Highway 80.

Owner: Layne-Atlantic Co.

AQUIFER.--Upper Floridan aquifer.

WELL CHARACTERISTICS.--Drilled unused supply well, diameter 4 in., depth $406 \mathrm{ft}$, cased to $250 \mathrm{ft}$, open hole.

DATUM.-Altitude of land-surface datum is $9.91 \mathrm{ft}$.

Measuring point: Top of 3 in. casing, $1.0 \mathrm{ft}$ above land-surface datum.

REMARKS.--Water levels for periods of missing record, November 13-25, 1990, were estimated.

PERIOD OF RECORD.--February 1954 to current year.

EXTREMES FOR PERIOD OF RECORD.--Highest water level, $49.17 \mathrm{ft}$ below land-surface datum, July 11, 1954; lowest,

$124.40 \mathrm{ft}$ below land-surface datum, August 30, 1980.

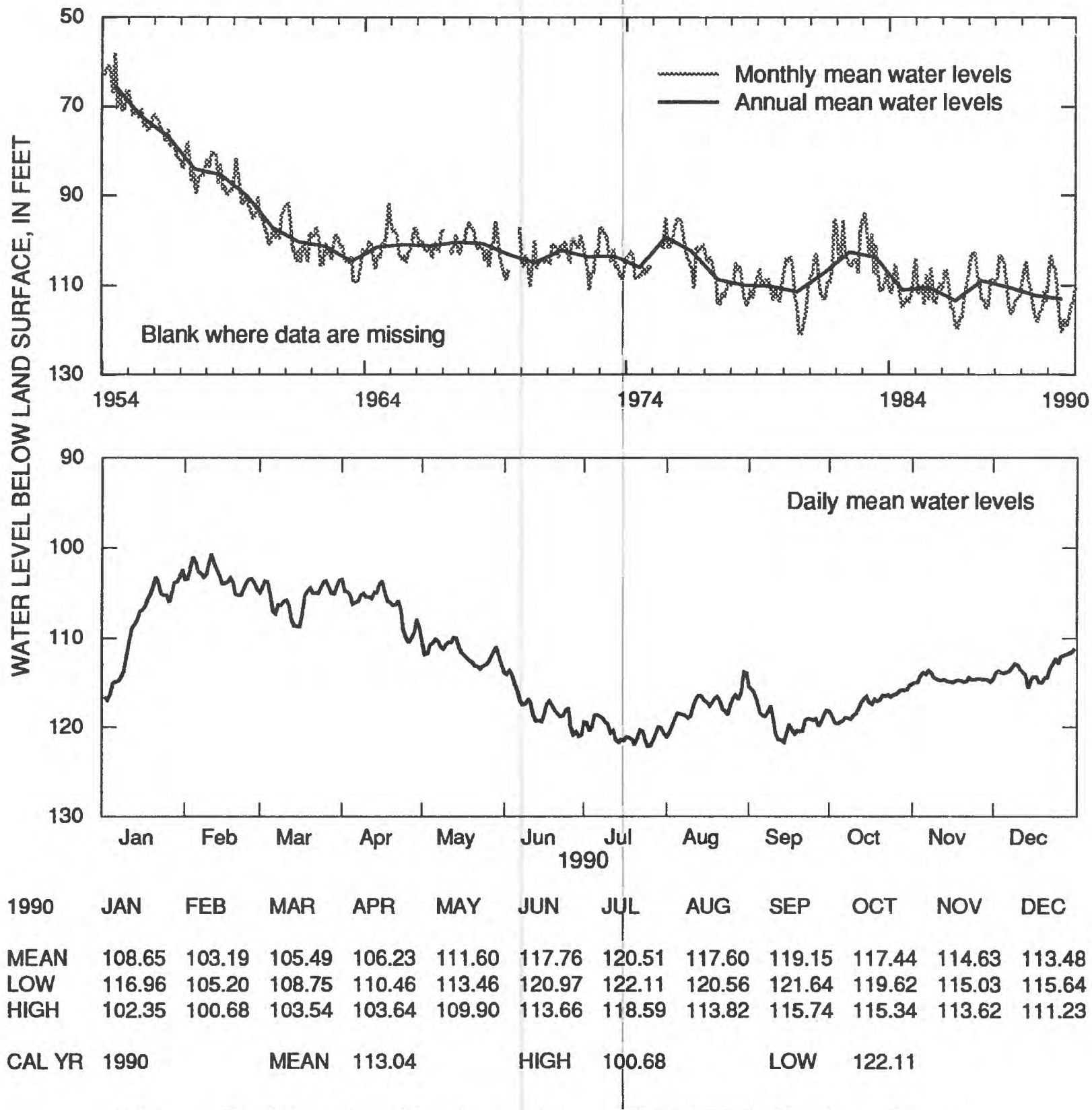

Figure 47.--Water level in observation well 36Q008, Chatham County. 
320021081124801 Local number, 36Q020.

LOCATION.--Lat $32^{\circ} 00^{\prime} 18^{\prime \prime}$, long $81^{\circ} 12^{\prime} 48^{\prime \prime}$, Hydrologic Unit $03060204,2.7 \mathrm{mi}$ south of intersection of U.S. Highway 17 with Dean Forest Road.

Owner: H. J. Morrison.

AQUIFER.-Upper Floridan.aquifer.

WELL CHARACTERISTICS.--Drilled unused supply well, diameter 3 in., depth $365 \mathrm{ft}$, cased to $330 \mathrm{ft}$, open hole.

DATUM.-Altitude of land-surface datum is $13 \mathrm{ft}$.

Measuring point: Top of recorder shelf, $3.88 \mathrm{ft}$ above land-surface darum.

REMARKS.-Borehole geophysical survey, May 7, 1985. Water levels for period of missing record, July 13-22,

were estimated.

PERIOD OF RECORD.-March 1958 to current year.

EXTREMES FOR PERIOD OF RECORD.--Highest water level, $17.66 \mathrm{ft}$ below land-surface datum, June 28, 1958; lowest, recorded, $58.56 \mathrm{ft}$ below land-surface datum, July 12, 1990, but may have been lower during period of estimated record from Julv 13-22. 1990.

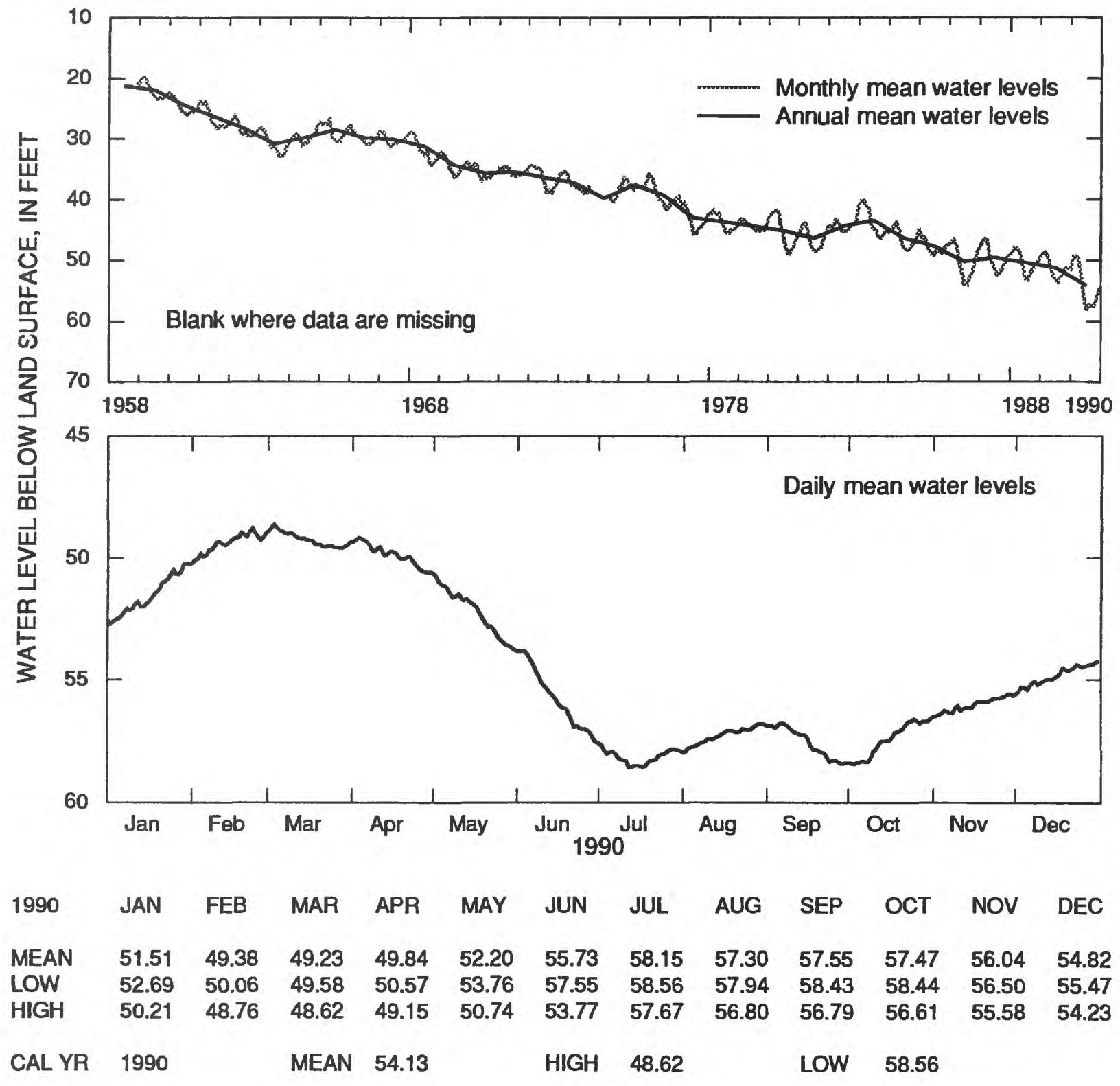

Figure 48.--Water level in observation well 36Q020, Chatham County. 
320202080541201 Local number, 38Q002.

LOCATION.--Lat 32 02'01", long 80'54'11", Hydrologic Unit 03060204, Cockspur Island, near pilot house.

Owner: U.S. Department of the Interior, National Park Service, test well 6.

AQUIFER.--Upper Floridan aquifer.

WELL CHARACTERISTICS.--Drilled observation well, diameter 8 in., depth $348 \mathrm{ft}$, cased to $110 \mathrm{ft}$, open hole.

DATUM.--Altitude of land-surface datum is $8.0 \mathrm{ft}$.

Measuring point: Top of recorder shelf, $3.62 \mathrm{ft}$ above land-surface datum.

REMARKS.--Borehole geophysical survey conducted June 16, 1961. Water levels for periods of missing record, May 19 to June 24 and December 3-21, were estimated.

PERIOD OF RECORD.--February 1956 to current year.

EXTREMES FOR PERIOD OF RECORD.--Highest water level, $16.00 \mathrm{ft}$ below land-surface datum, March 5, 1956; lowest, $40.69 \mathrm{ft}$ below land-surface datum, July 16, 1990.

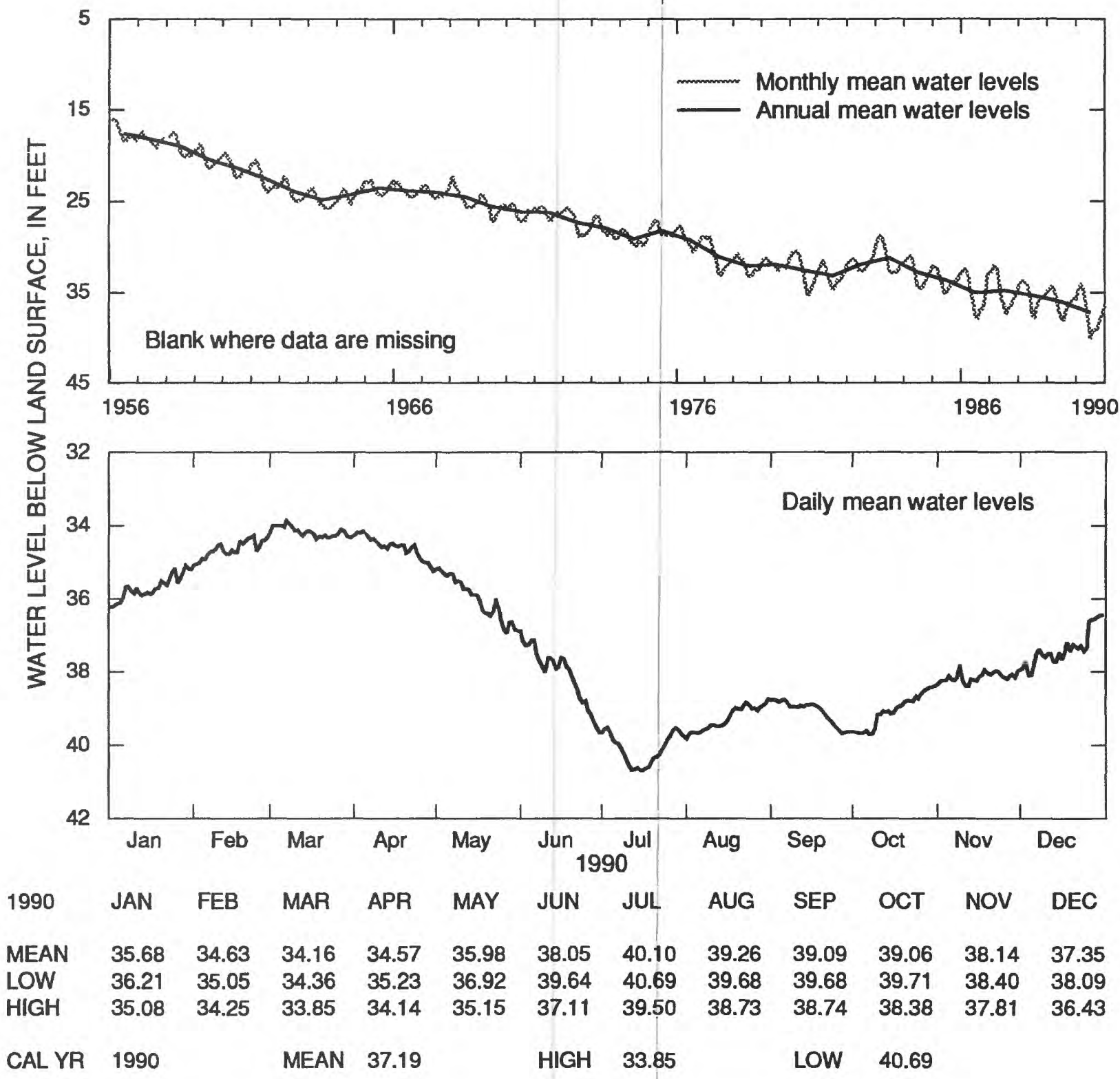

Figure 49.--Water level in observation well $38 \mathrm{Q} 002$, Chatham County. 
320122080510204 Local number, 390003.

LOCATION.--Lat $32^{\circ} 01^{\prime 22}$ ", long 80 51'01", Hydrologic Unit 03060204, Tybee Island near Fort Screven.

Owner: U.S. Geological Survey, test well 7.

AQUIFER.--Upper Floridan aquifer.

WELL CHARACTERISTICS.--Drilled observation well, diameter $10 \mathrm{in}$., depth $600 \mathrm{ft}$, cased to $129 \mathrm{ft}$, open hole.

DATUM.--Altitude of land-surface datum is $7.0 \mathrm{ft}$.

Measuring point: Top of $10 \mathrm{in}$. casing, $2.0 \mathrm{ft}$ above land-surface datum.

REMARKS.-Borehole geophysical survey conducted January 24, 1962. Water levels for period of missing record,

March 14 to April 22, were estimated.

PERIOD OF RECORD.--May 1962 to current year; continuous record, September 1965 to current year.

EXTREMES FOR PERIOD OF RECORD.--Highest water level, $17.80 \mathrm{ft}$ below land-surface datum, April 11, 1963; lowest,

$36.07 \mathrm{ft}$ below land-surface datum, July 11-12, 1990 .

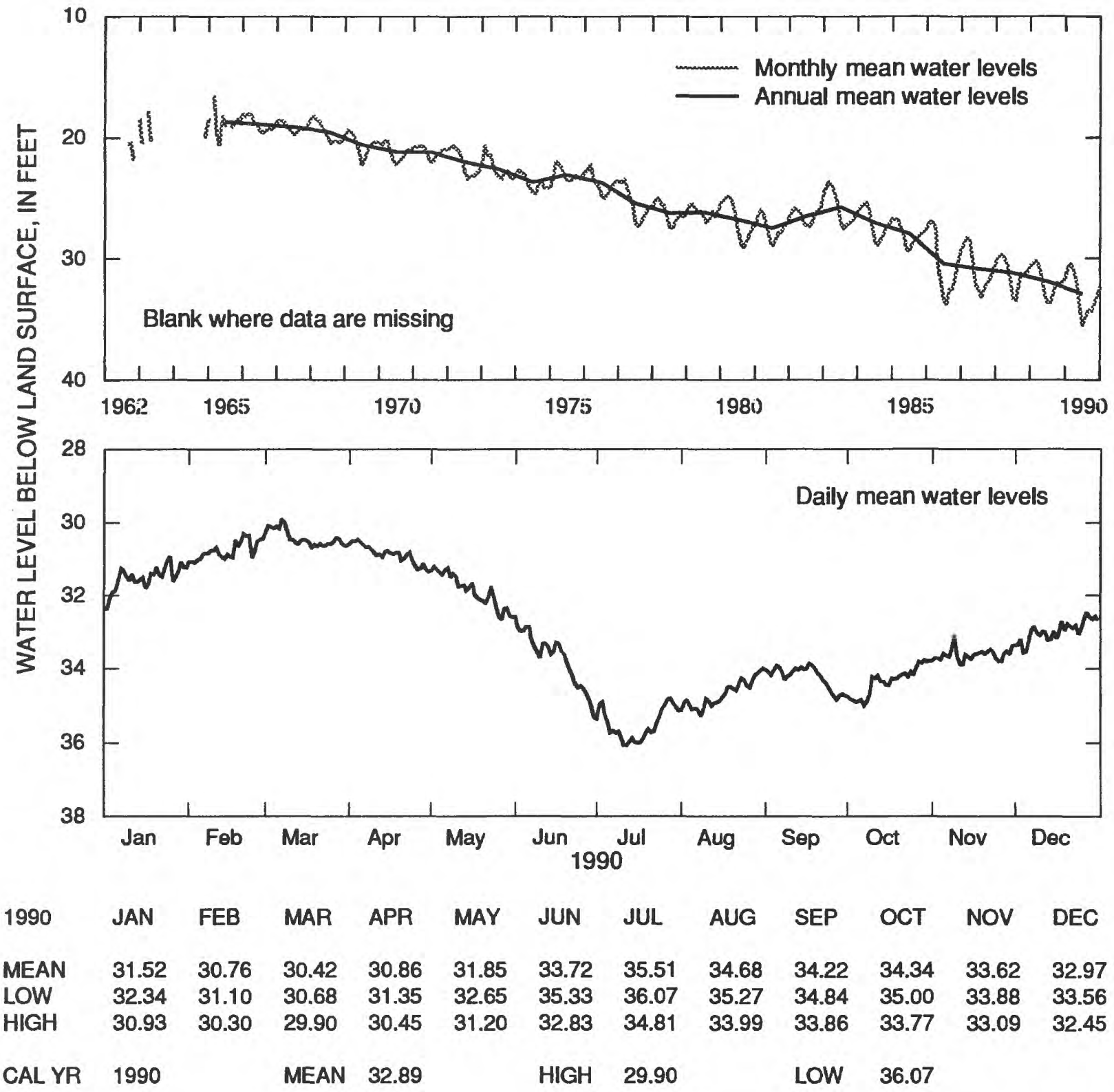

Figure 50.--Water level in observation well 390003, Chatham County. 
321240081411501 Local number, 32R002.

LOCATION.--Lat 32 $12^{\prime} 40^{\prime \prime}$, long $81^{\circ} 41^{\prime \prime} 15^{\prime \prime}$, Hydrologic Unit 03060202, 2.6 mi north along Georgia Highway 67 from the Bulloch-Bryan County line, approximately $100 \mathrm{ft}$ east of center line of road.

Owner: Georgia Geologic Survey, Bulloch South test well 1.

AQUIFER.--Upper Floridan aquifer.

WELL CHARACTERISTICS.--Drilled observation well, diameter 6 in., depth $804 \mathrm{ft}$, cased to $420 \mathrm{ft}$, open hole.

DATUM.-Altitude of land-surface datum is $120 \mathrm{ft}$.

Measuring point: Top of recorder shelf, $3.0 \mathrm{ft}$ above land-surface datum.

REMARKS.--Borehole geophysical survey and well sounded August 1982.

PERIOD OF RECORD.--February 1983 to current year.

EXTREMES FOR PERIOD OF RECORD.--Highest water level, $85.08 \mathrm{ft}$ below land-surface datum, April 24, 1983; lowest,

$95.94 \mathrm{ft}$ below land-surface datum, October 8, 1990 .

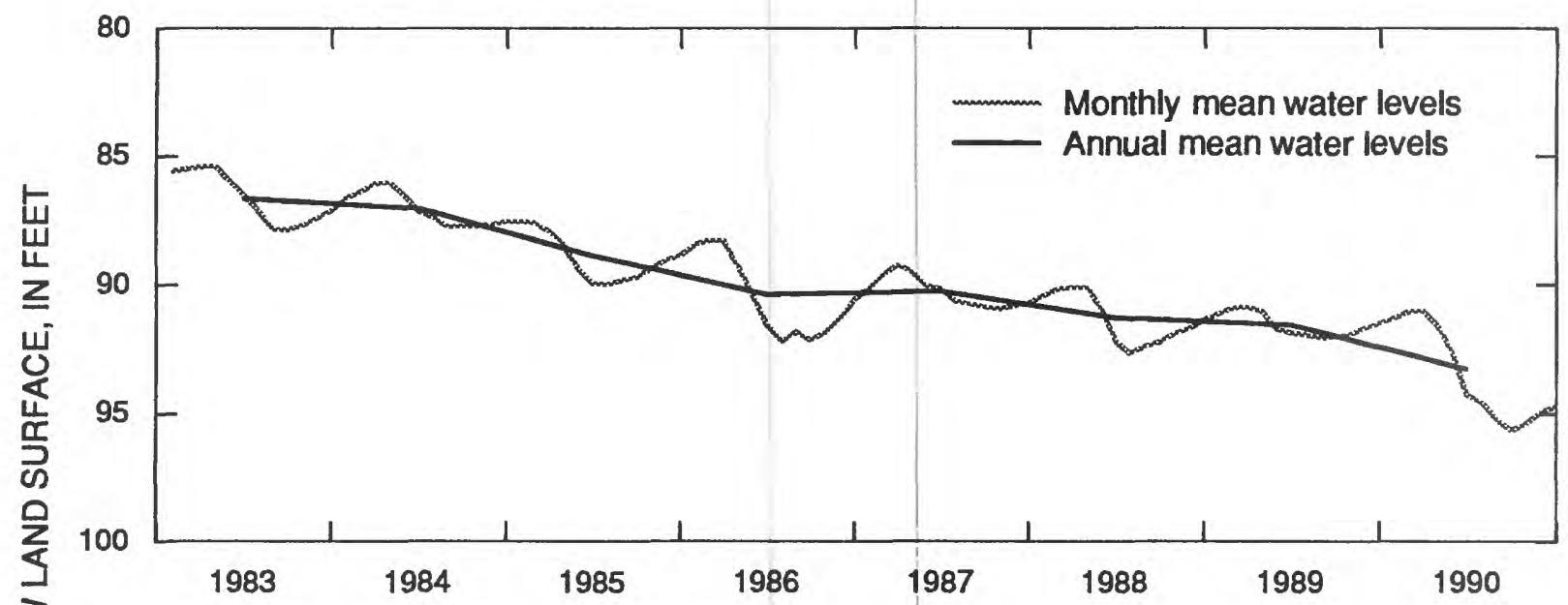

88

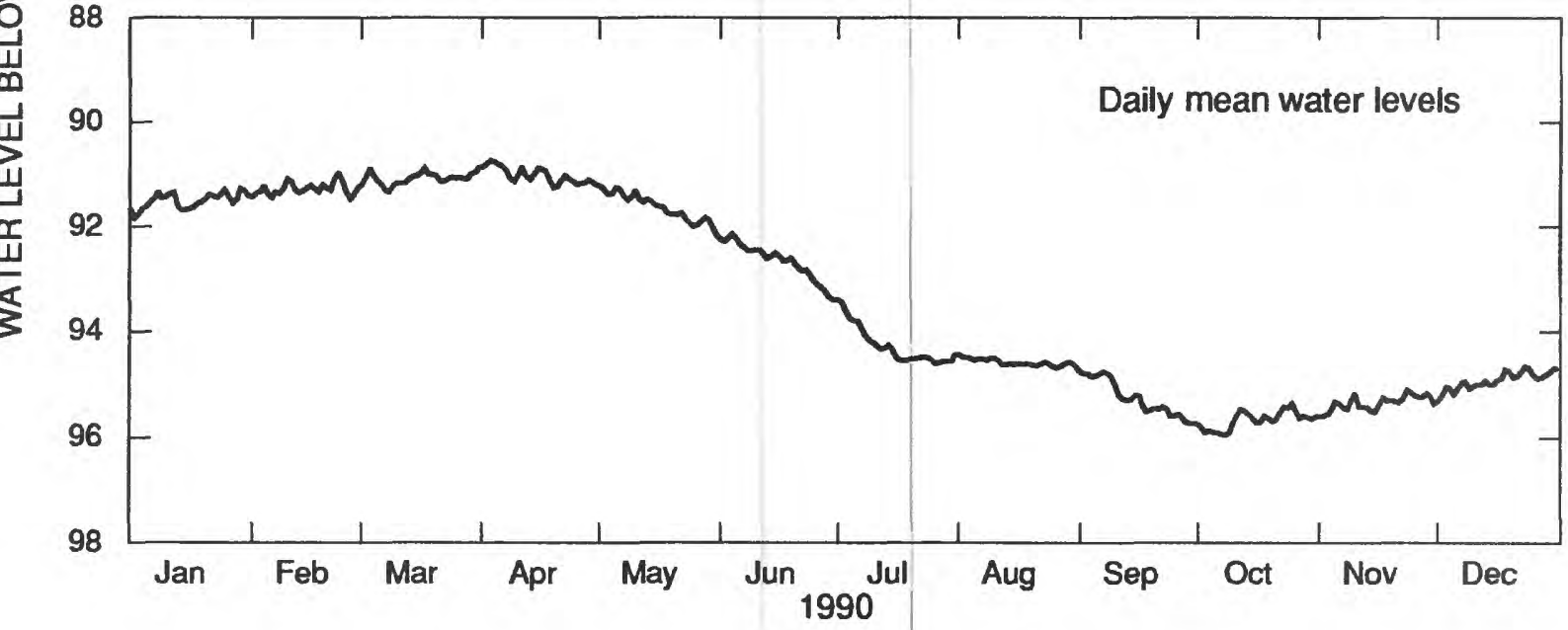

$\begin{array}{lllllllllllll}1990 & \text { JAN } & \text { FEB } & \text { MAR } & \text { APR } & \text { MAY } & \text { JUN } & \text { JUL } & \text { AUG } & \text { SEP } & \text { OCT } & \text { NOV } & \text { DEC } \\ \text { MEAN } & 91.49 & 91.27 & 91.07 & 91.01 & 91.62 & 92.65 & 94.26 & 94.58 & 95.24 & 95.66 & 95.34 & 94.92 \\ \text { LOW } & 91.82 & 91.47 & 91.32 & 91.24 & 92.15 & 93.39 & 94.61 & 94.68 & 95.73 & 95.94 & 95.58 & 95.19 \\ \text { HIGH } & 91.26 & 90.95 & 90.86 & 90.73 & 91.25 & 92.14 & 93.43 & 94.48 & 94.76 & 95.35 & 95.11 & 94.66 \\ \text { CAL YR } & 1990 & & \text { MEAN } & 93.27 & & \text { HIGH } & 90.73 & & \text { LOW } & 95.94 & & \end{array}$

Figure 51.--Water level in observation well 32R002, Bulloch County. 
314343081251901 Local number, 34M054.

LOCATION.-Lat $31^{\circ} 43^{\prime} 43^{\prime \prime}$, long $81^{\circ} 25^{\prime} 19$ ", Hydrologic Unit 03060204, Riceboro, near entrance to Interstate

Paper Company.

Owner: U.S. Geological Survey, test well 2.

AQUIFER.--Upper Floridan aquifer.

WELL CHARACTERISTICS.--Drilled observation well, diameter 4 in., depth $802 \mathrm{ft}$, cased to $467 \mathrm{ft}$, open hole.

DATUM.--Altitude of land-surface datum is $19 \mathrm{ft}$.

Measuring point: Top of recorder shelf, $3.4 \mathrm{ft}$ above land-surface datum.

REMARKS.--Well pumped July 11, 1979; water-quality sample collected at conclusion of pumping. Borehole geophysical survey conducted June 15, 1976. Water levels for period of missing record, June 15-25, were estimated.

PERIOD OF RECORD.--February 1967 to current year.

EXTREMES FOR PERIOD OF RECORD.--Highest water level, $0.85 \mathrm{ft}$ below land-surface datum, February 5, 1967; lowest, $32.34 \mathrm{ft}$ below land-surface datum, November 14, 1990.

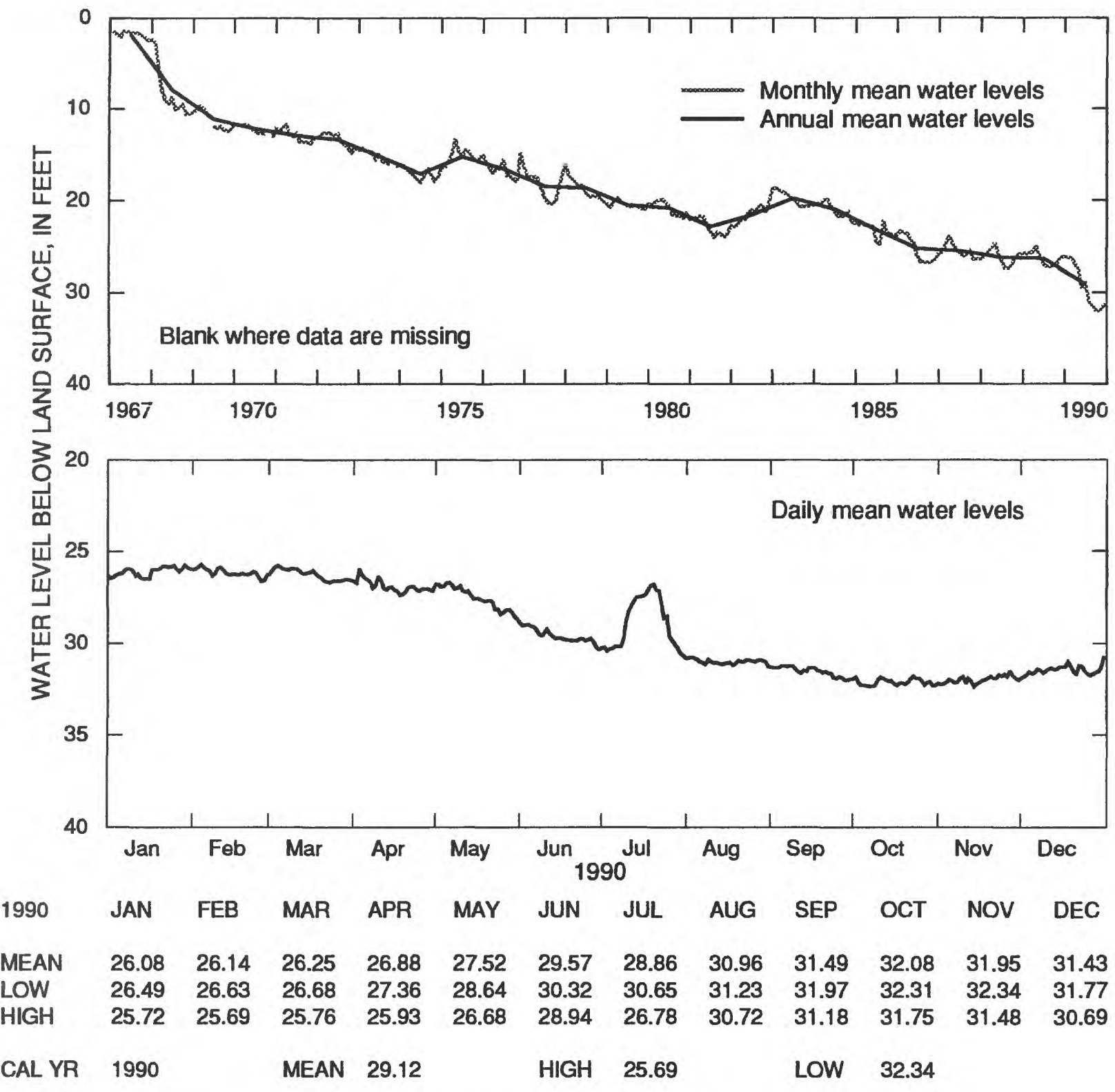

Figure 52.--Water level in observation well 34M054, Liberty County. 
315214081235301 Local number, 34N089.

LOCATION.--Lat 31 '52'14", long 81 '23'53", Hydrologic Unit 03060204, north of Midway, near intersection of Georgia Highway 196 and U.S. Highway 17.

Owner: U.S. Geological Survey, test well 1.

AQUIFER.--Upper Floridan aquifer.

WELL CHARACTERISTICS.--Drilled observation well, diameter 4 in., depth $789 \mathrm{ft}$, cased to $410 \mathrm{ft}$, open hole.

DATUM.-Altitude of land-surface datum is $17 \mathrm{ft}$.

Measuring point: Top of $4 \mathrm{in}$. casing, $1.33 \mathrm{ft}$ above land-surface datum.

REMARKS.-Well pumped July 11, 1979; water-quality sample collected at conclusion of pumping. Borehole geophysical survey conducted June 15, 1976. Water levels for periods of missing record, June 17-25, were

estimated.

PERIOD OF RECORD.--February 1967 to current year.

EXTREMES FOR PERIOD OF RECORD.--Highest water level, $2.34 \mathrm{ft}$ below land-surface datum, March 6, 1967; lowest,

$29.43 \mathrm{ft}$ below land-surface datum, October 3, 1990.

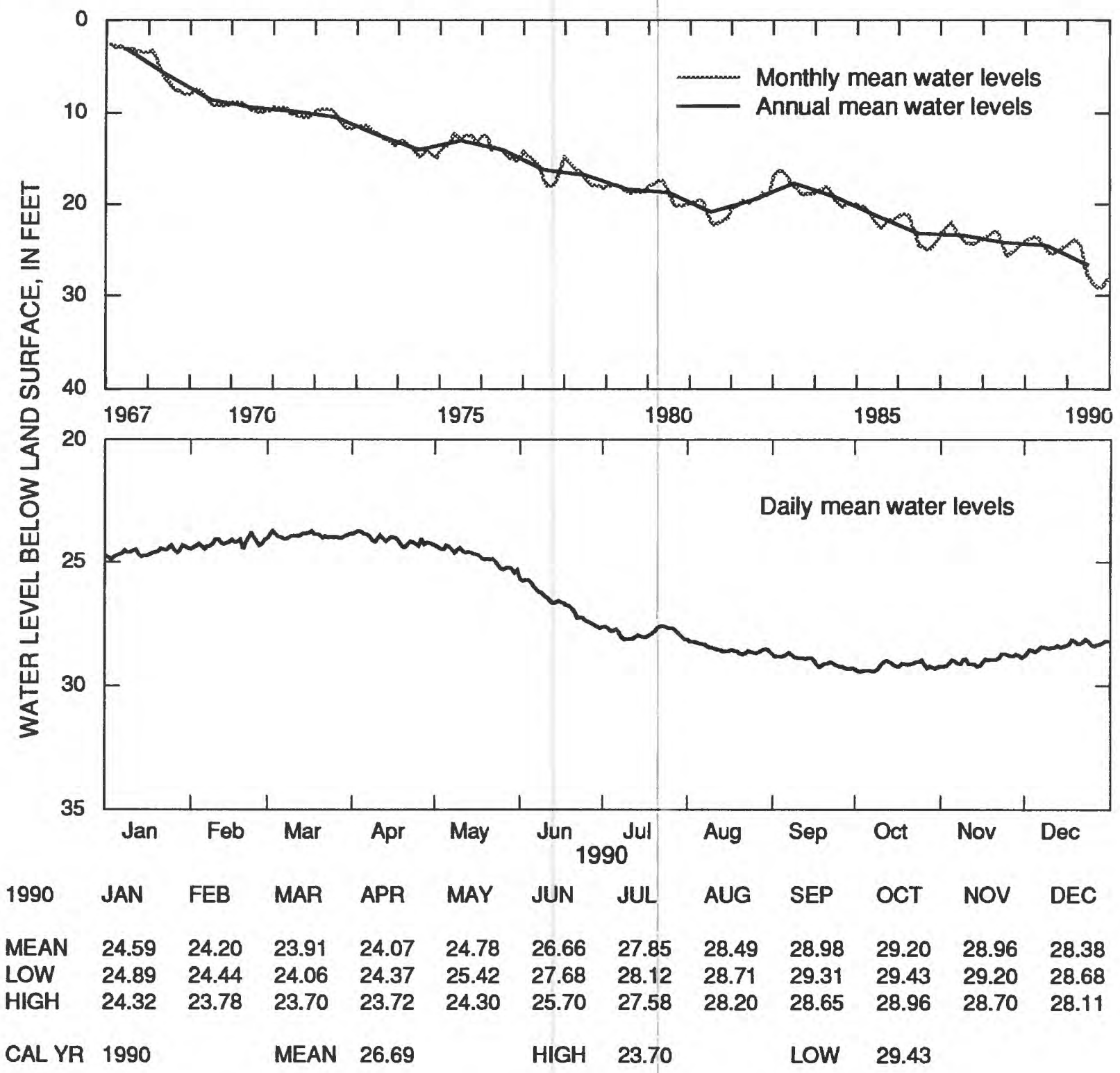

Figure 53.--Water level in observation well 34N089, Liberty County. 
313823081154201 Local number, 35M013.

LOCATION.--Lat $31^{\circ} 38^{\prime 2} 23^{\prime \prime}$, long $81^{\circ} 15^{\prime} 42^{\prime \prime}$, Hydrologic Unit 03060204, 8.5 mi east of U.S. Highway 17 at Harris Neck

Wildlife Refuge.

Owner: U.S. Department of the Interior, Fish and Wildlife Service.

AQUIFER.--Upper Floridan aquifer.

WELL CHARACTERISTICS.--Drilled unused supply well, diameter $10 \mathrm{in}$., depth $553 \mathrm{ft}$, cased to $376 \mathrm{ft}$, open hole.

DATUM.--Altitude of land-surface datum is $16.3 \mathrm{ft}$.

Measuring point: Top of recorder shelf, $3.2 \mathrm{ft}$ above land-surface datum.

REMARKS.--Well pumped August 3, 1976; water-quality sample collected at conclusion of pumping. Borehole geophysical survey conducted June 16, 1976. Water levels for period of missing record, December 13-20, were estimated.

PERIOD OF RECORD.--September 1966 to current year.

EXTREMES FOR PERIOD OF RECORD.--Highest water level, $4.35 \mathrm{ft}$ below land-surface datum, October 4, 1966; lowest, $26.88 \mathrm{ft}$ below land-surface datum, November 14, 1990.

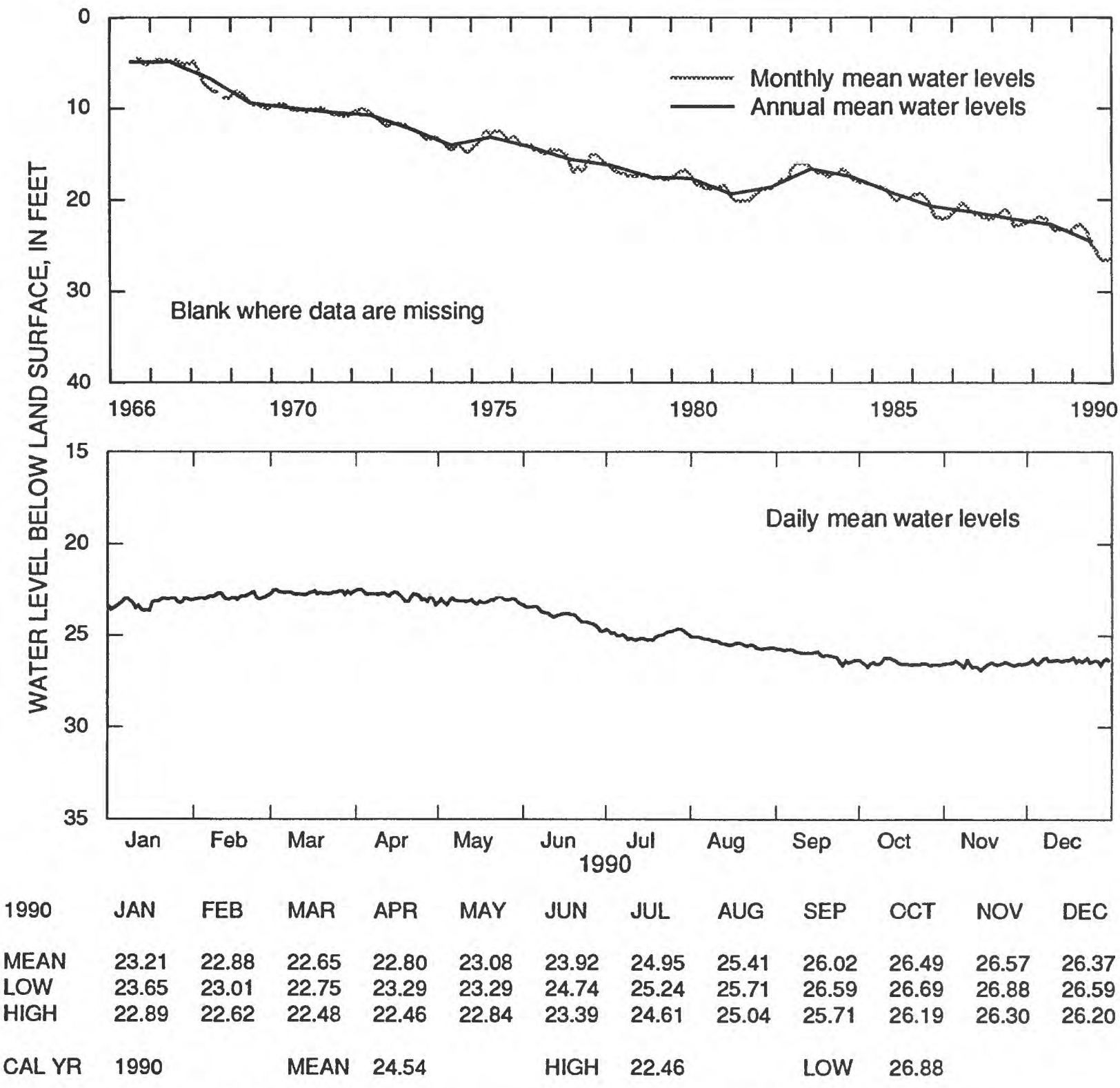

Figure 54.--Water level in observation well 35M013, McIntosh County. 
The water level in the Upper Floridan aquifer in the Jesup-Doctortown subarea is monitored in three wells, all of which are summarized in this report (fig. 46). In this area, water levels in wells tapping the aquifer are affected mainly by industrial pumping at Doctortown (near Jesup). In 1987, pumpage averaged about 74 Mgal/d at Doctortown (Trent and others, 1990). Hydrographs for wells $30 \mathrm{LO03}$ (fig. 55), 32L015 (fig. 56), and 33M004 (fig. 57) illustrate the effects that a partial industrial shutdown by a major ground-water user had on the water levels in the Jesup-Doctortown area in April and November 1990. The 1990 mean water levels in the three wells were from about 1.4 to $1.8 \mathrm{ft}$ lower than in 1989, continuing a downward trend that began in 1983. Record-low daily mean water levels were recorded in the three wells (figs. 55-57) during October 1990 that were from about 2.8 to $3.3 \mathrm{ft}$ lower than the previous record lows. These declines may be attributed to increased regional pumping as a result of below-normal precipitation. 
313701081543501 Local number, 30 L003.

LOCATION.--Lat $31^{\circ} 37^{\circ} 01^{\prime \prime}$, long $81^{\circ} 54^{\prime 3} 34^{\prime \prime}$, Hydrologic Unit 03070106 , about 0.5 mi west of Jesup city limits near intersection of U.S. Highway 341 and Sunset Drive.

Owner: City of Jesup Housing Authority.

AQUIFER.--Upper Floridan aquifer.

WELL CHARACTERISTICS.--Drilled unused supply well, diameter 4 in., depth $584 \mathrm{ft}$, cased to $472 \mathrm{ft}$, open hole.

DATUM.--Altitude of land-surface datum is $107 \mathrm{ft}$.

Measuring point: Top of recorder shelf, $2.88 \mathrm{ft}$ above land-surface datum.

REMARKS.--Borehole geophysical survey conducted August 19, 1963. Water levels for period of missing record,

May 10 to June 27, were estimated.

PERIOD OF RECORD.--January 1964 to March 1967. February 1976 to current year.

EXTREMES FOR PERIOD OF RECORD.--Highest water level, $59.98 \mathrm{ft}$ below land-surface datum, April 19, 1964; lowest, $88.91 \mathrm{ft}$ below land-surface datum, October 7, 1990.

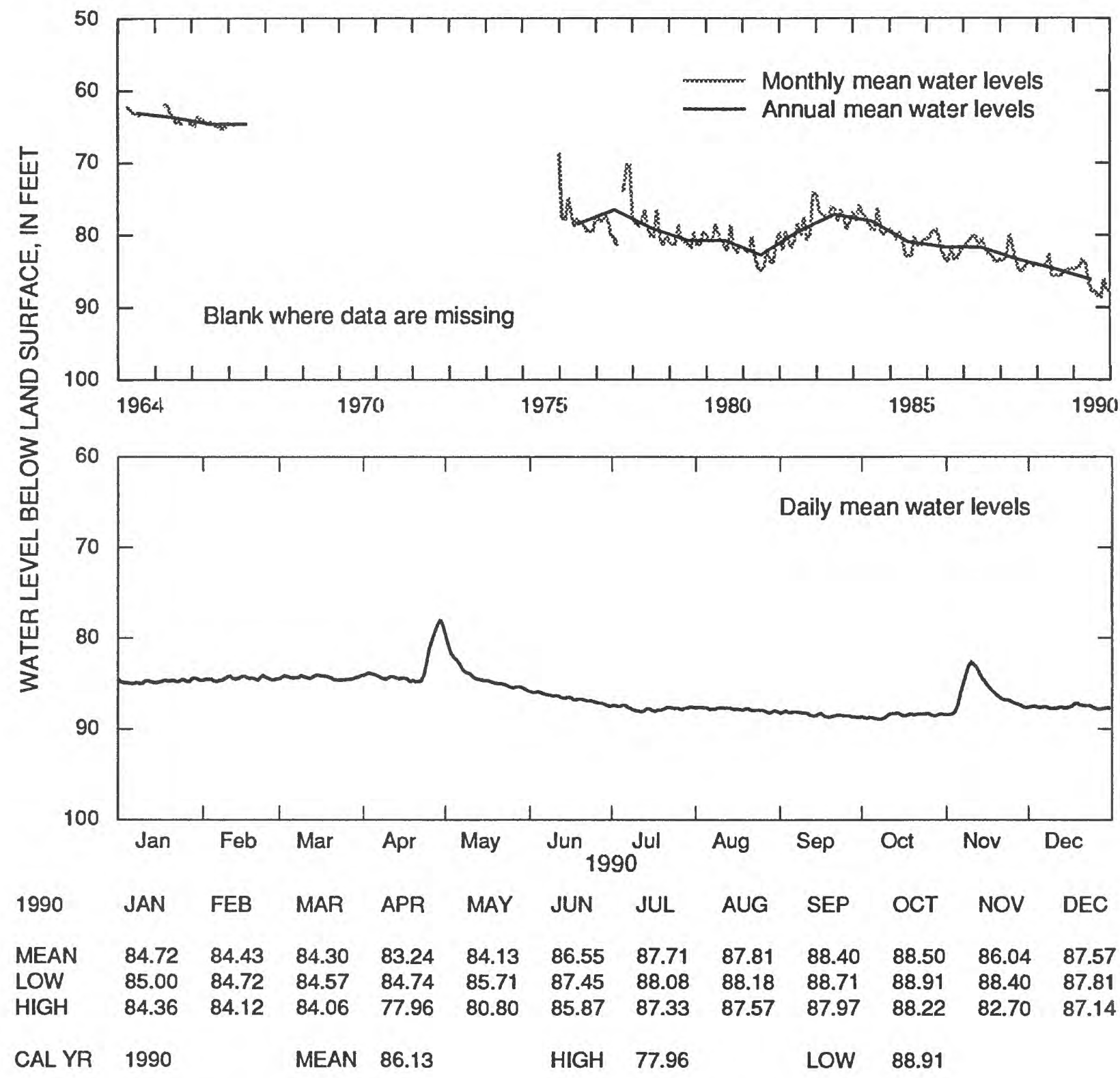

Figure 55.--Water level in observation well 30L003, Wayne County. 
313253081433502 Local number, 32L015.

LOCATION.-Lat 31 32'52", long 81 $43^{\prime} 36^{\prime \prime}$, Hydrologic Unit 03070106, westernmost of three recorder wells, $0.8 \mathrm{mi}$ north of

Gardi Road, on right side of dirt road, $4.3 \mathrm{mi}$ east of Gardi.

Owner: Georgia Geologic Survey, Gardi test well 1.

AQUIFER.--Upper Floridan aquifer.

WELL CHARACTERISTICS.--Drilled observation well, diameter 4 in., depth $750 \mathrm{ft}$, cased to $545 \mathrm{ft}$, open hole.

DATUM.--Altitude of land-surface datum is $74 \mathrm{ft}$.

Measuring point: Top of recorder shelf, $4.0 \mathrm{ft}$ above land-surface datum.

REMARKS.--Borehole geophysical survey conducted April 20, 1983.

PERIOD OF RECORD.--April 20, 1983, to current year.

EXTREMES FOR PERIOD OF RECORD.--Highest water level, $49.12 \mathrm{ft}$ below land-surface datum, March 19, 1984; lowest, $64.05 \mathrm{ft}$ below land-surface datum, October 7-8, 1990.

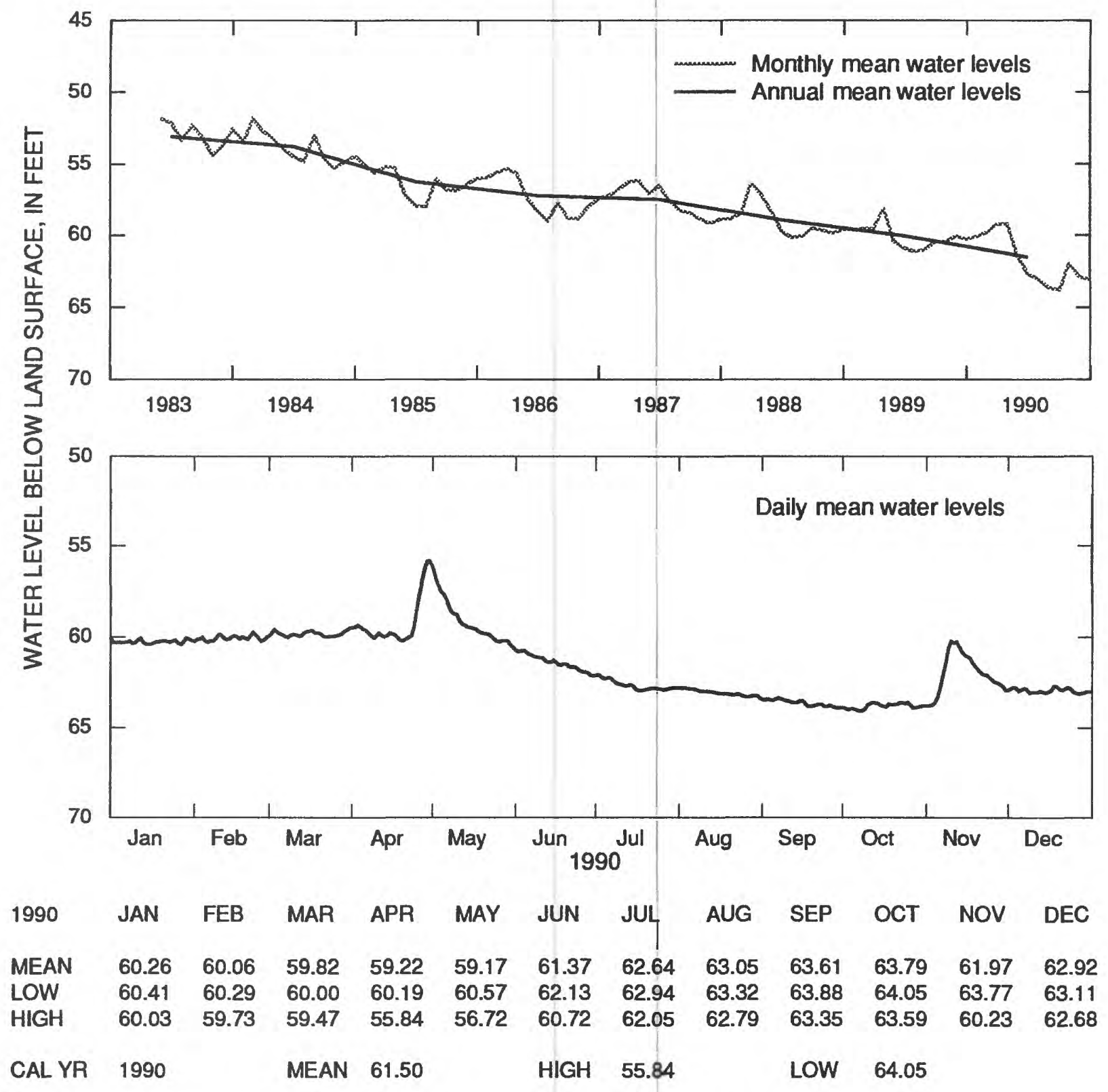

Figure 56.--Water level in observation well 32L015, Wayne County. 
313845081361701 Local number, 33M004.

LOCATION.--Lat $31^{\circ} 38^{\prime} 54^{\prime \prime}$ long $81^{\circ} 36^{\prime} 04^{\prime \prime}$, Hydrologic Unit $03070106,9.0 \mathrm{mi}$ southeast of Ludowici, at Hope Cemetery.

Owner: U.S. Geological Survey, test well 3.

AQUIFER.--Upper Floridan aquifer.

WELL CHARACTERISTICS.--Drilled observation well, diameter 4-3 in., depth $872 \mathrm{ft}$, cased to $538 \mathrm{ft}$, open hole.

DATUM.--Altitude of land-surface datum is $61.2 \mathrm{ft}$.

Measuring point: Top of recorder shelf, $3.5 \mathrm{ft}$ above land-surface datum.

REMARKS.-Well pumped and sounded June 17, 1976, to depth of $861 \mathrm{ft}$; water-quality sample collected. Borehole geophysical survey conducted July 28, 1976.

PERIOD OF RECORD.--January 1968 to current year.

EXTREMES FOR PERIOD OF RECORD.--Highest water level, $34.04 \mathrm{ft}$ below land-surface datum, January 14, 1968; lowest, $59.00 \mathrm{ft}$ below land-surface datum, October 8, 1990.
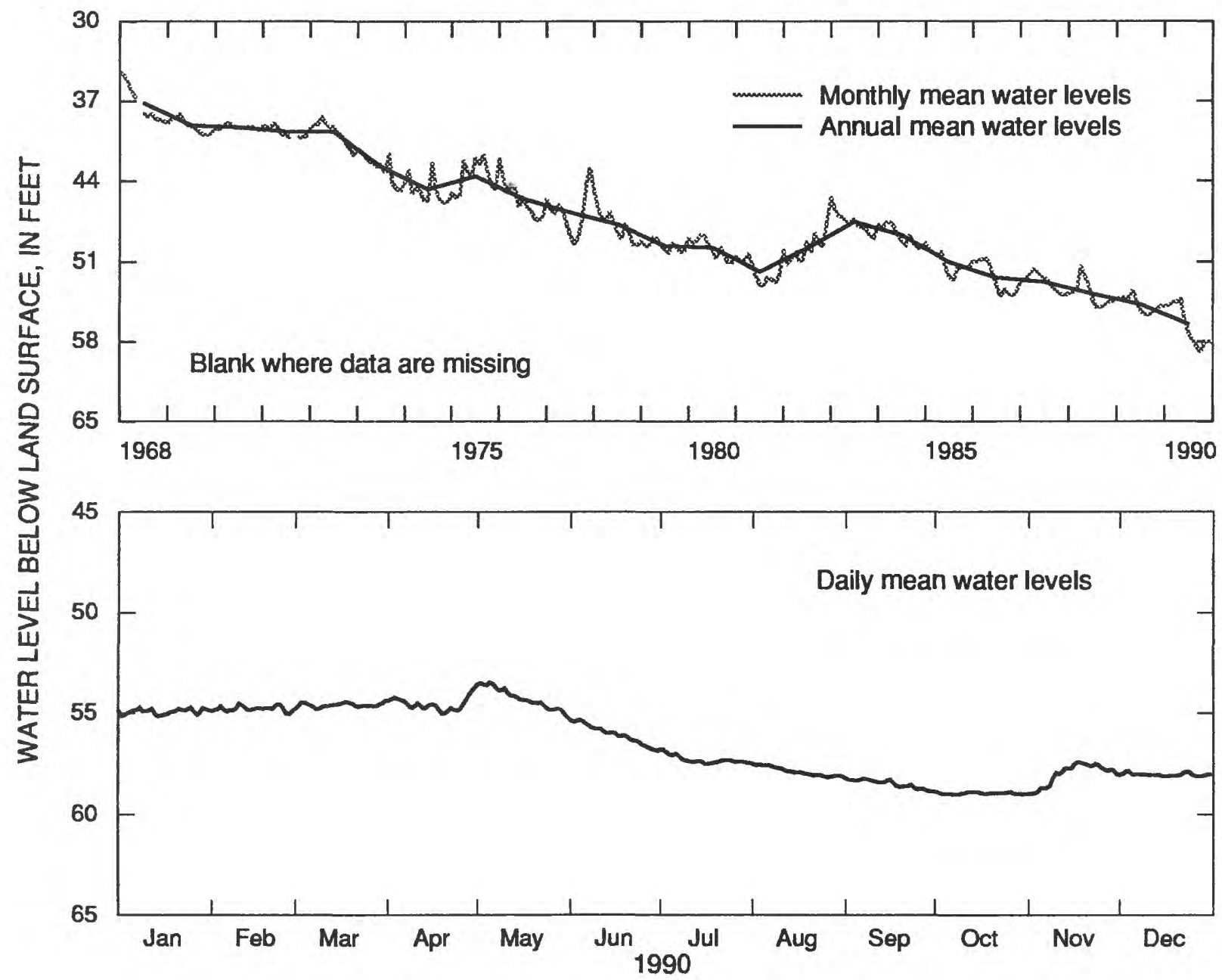

$\begin{array}{lllllllllllll}1990 & \text { JAN } & \text { FEB } & \text { MAR } & \text { APR } & \text { MAY } & \text { JUN } & \text { JUL } & \text { AUG } & \text { SEP } & \text { OCT } & \text { NOV } & \text { DEC } \\ \text { MEAN } & 54.90 & 54.77 & 54.58 & 54.53 & 54.24 & 56.03 & 57.28 & 57.86 & 58.47 & 58.94 & 58.00 & 58.01 \\ \text { LOW } & 55.12 & 55.03 & 54.81 & 55.01 & 55.20 & 56.83 & 57.51 & 58.14 & 58.85 & 59.00 & 58.96 & 58.10 \\ \text { HIGH } & 54.70 & 54.52 & 54.37 & 53.69 & 53.46 & 55.32 & 56.79 & 57.53 & 58.22 & 58.86 & 57.40 & 57.85 \\ \text { CAL YR } & 1990 & & \text { MEAN } & 56.48 & & \text { HIGH } & 53.46 & & \text { LOW } & 59.00 & & \end{array}$

Figure 57.--Water level in observation well 33M004, Long County. 
The water level in the Upper Floridan aquifer in the Brunswick subarea is monitored in six wells, two of which are summarized in this report (fig. 46). In this subarea, water levels in wells tapping this aquifer are affected primarily by industrial pumping, which averaged about $70 \mathrm{Mgal} / \mathrm{d}$ in 1987 (Trent and others, 1990). This pumping has resulted in the development of a cone of depression centered at Brunswick (fig. 28). The water-level response to pumping is illustrated on the hydrographs for wells $33 \mathrm{H} 127$ (fig. 58) tapping the lower water-bearing zone of the Upper Floridan aquifer, and well 33H133 (fig. 59) tapping the upper water-bearing zone of the Upper Floridan aquifer. In 1990, a partial industrial shutdown, during which the major groundwater user stopped pumping, is reflected by a sharp water-level rise during May. The annual mean water levels in wells 33H127 (fig. 58) and 33H133 (fig. 59) were about 1.4 and $1.6 \mathrm{ft}$ lower in 1990 than in 1989, respectively. A record-low daily mean water level was recorded in well $33 \mathrm{H} 127$ (fig. 58) in July that was about $2.0 \mathrm{ft}$ lower than the previous record low. These declines continued downward trends that began in 1984 (figs. 58 and 59). 
311007081301701 Local number, $33 \mathrm{H} 127$.

LOCATION.--Lat $31^{\circ} 10^{\prime} 06^{\prime \prime}$, long $81^{\circ} 30^{\prime \prime} 16^{\prime \prime}$, Hydrologic Unit 03070203, in south corner of Greenwood Cemetery, in

Brunswick.

Owner: U.S. Geological Survey, test well 3.

AQUIFER.--Upper Floridan aquifer; lower water-bearing zone.

WELL CHARACTERISTICS.--Drilled observation well, diameter 4 in., depth 1,002 ft, cased to $823 \mathrm{ft}$, open hole.

DATUM.--Altitude of land-surface datum is $6.2 \mathrm{ft}$.

Measuring point: Top of recorder shelf, $8.00 \mathrm{ft}$ above land-surface datum.

REMARKS.--Well pumped and sampled for analysis of chloride concentration semi-annually.

Water levels for periods of missing record, June 26, July 24-30, and November 22-27, were estimated.

PERIOD OF RECORD.-August 1962 to current year.

EXTREMES FOR PERIOD OF RECORD.--Highest water level, $14.00 \mathrm{ft}$ above land-surface datum, October 9, 1962; lowest,

$13.22 \mathrm{ft}$ below land-surface datum, July 9, 1990 .
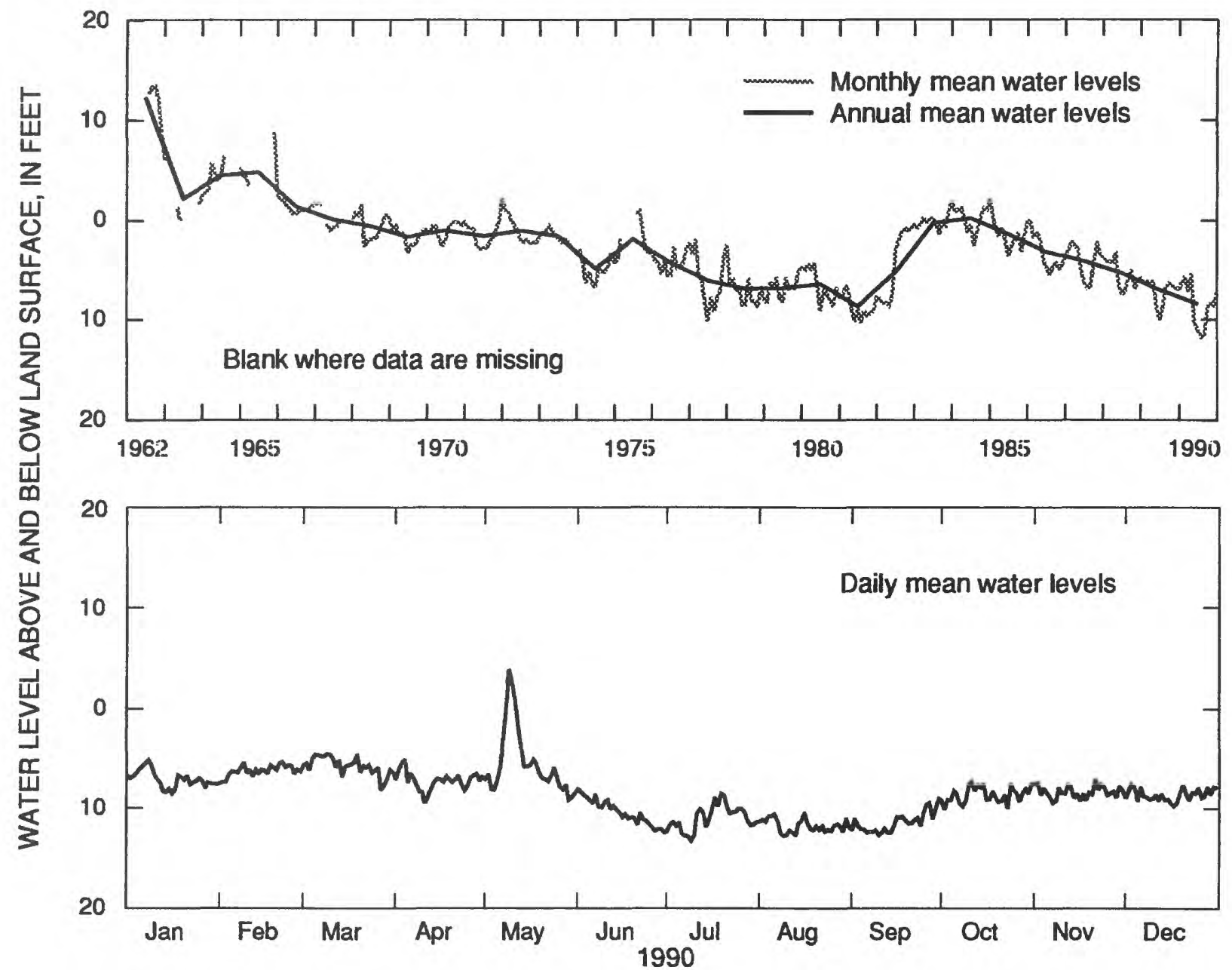

$\begin{array}{rrrrrrrrrrrrr}1990 & \text { JAN } & \text { FEB } & \text { MAR } & \text { APR } & \text { MAY } & \text { JUN } & \text { JUL } & \text { AUG } & \text { SEP } & \text { OCT } & \text { NOV } & \text { DEC } \\ \text { MEAN } & 7.03 & 6.20 & 5.69 & 7.19 & 5.44 & 10.33 & 10.94 & 11.70 & 11.39 & 8.61 & 8.29 & 8.58 \\ \text { LOW } & 8.47 & 7.29 & 8.09 & 9.46 & 9.11 & 12.38 & 13.22 & 12.74 & 12.64 & 10.10 & 9.42 & 9.73 \\ \text { HIGH } & 5.13 & 5.34 & 4.48 & 5.06 & -3.86 & 8.25 & 8.48 & 10.35 & 8.96 & 7.31 & 7.06 & 7.50 \\ \text { CAL YR } & 1990 & & \text { MEAN } & 8.46 & & \text { HIGH } & -3.86 & & \text { LOW } & 13.22 & & \end{array}$

[Negative value indicates water level above land surface]

Figure 58.--Water level in observation well 33H127, Glynn County. 
311007081301702 Local number, $33 \mathrm{H} 133$.

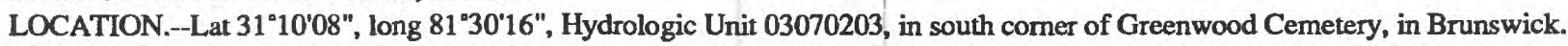
Owner: U.S. Geological Survey, test well 6.

AQUIFER.--Upper Floridan aquifer; upper water-bearing zone.

WELL CHARACTERISTICS.--Drilled observation well, diameter 4 in., depth $790 \mathrm{ft}$, cased to $520 \mathrm{ft}$, open hole.

DATUM.-Altitude of land-surface datum is $6.7 \mathrm{ft}$.

Measuring point: Top of recorder shelf, $5.1 \mathrm{ft}$ above land-surface datum.

REMARKS.--Well pumped and sampled for analysis of chloride concentration semi-annually. Borehole geophysical survey conducted September 26, 1977. Water levels for period of missing record, August 25-28, September 4-25, and October 6-24, were estimated.

PERIOD OF RECORD.--January 1963 to current year.

EXTREMES FOR PERIOD OF RECORD.--Highest water level, $9.07 \mathrm{ft}$ above land-surface datum, December 26, 1965; lowest, $21.87 \mathrm{ft}$ below land-surface datum, July 22, 1977.

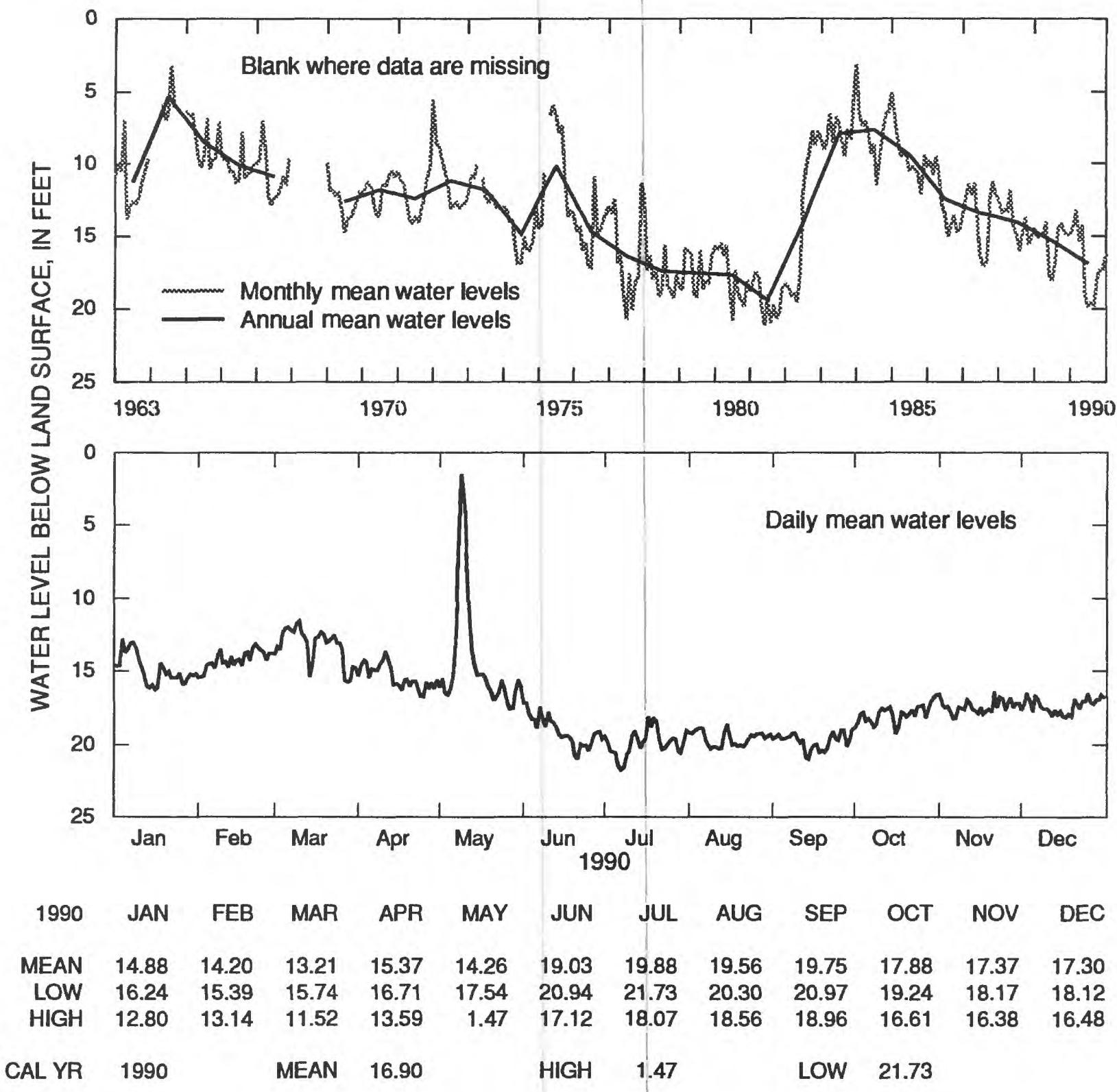

Figure 59.--Water level in observation well $33 \mathrm{H} 133$, Glynn County. 
The water level in the Upper Floridan aquifer in the St Marys-Okefenokee Swamp subarea is monitored in two wells, both of which are summarized in this report (fig. 46). Water levels in wells tapping the aquifer in this subarea are affected by industrial pumping that averages about $34 \mathrm{Mgal} / \mathrm{d}$ in 1987 at St Marys, Ga. (Trent and others, 1990), and about $37 \mathrm{Mgal} / \mathrm{d}$ in 1985 at Fernandina Beach, Fla. (Marella, 1986). Pumping in these areas has resulted in the formation of a cone of depression centered at Fernandina Beach, Fla., and to a lesser extent at St Marys, Ga. (fig. 28).

The 1990 mean water levels in well 33E027 (fig. 60) at Kings Bay and well 27E004 (fig. 61) in western Charlton County were about $0.6 \mathrm{ft}$ and $0.9 \mathrm{ft}$ lower than in 1989 , respectively. These water levels continued the general declining water-level trend in the area that began in 1983-84 (figs. 60 and 61). A record-low daily mean water level was recorded in well $27 \mathrm{E} 004$ (fig. 61) in October 1990 that was about $2.0 \mathrm{ft}$ lower than the previous record low. These water-level declines may be attributed to increased pumping in the area as a result of belownormal precipitation. 
304756081311101 Local number, 33E027.

LOCATION.--Lat 304'56", long 81³1'11", Hydrologic Unit 03070203, Naval Submarine Base, Kings Bay.

Owner: U.S. Department of the Navy, Kingsbay test well 1.

AQUIFER.--Upper Floridan aquifer.

WELL CHARACTERISTICS.--Drilled test well, diameter 8 in., depth 1,306 ft, cased to $555 \mathrm{ft}$, backfilled to $990 \mathrm{ft}$, open hole.

DATUM.--Altitude of land-surface datum is $10.0 \mathrm{ft}$.

Measuring point: Top of flange at land-surface datum.

REMARKS.--Borehole geophysical survey conducted February 9, 1979. Water levels for periods of missing record, January

23-30, March 20-27, August 14-19 and October 7 to December 31, were estimated.

PERIOD OF RECORD.--August 1979 to current year.

EXTREMES FOR PERIOD OF RECORD.--Highest water level, $24.71 \mathrm{ft}$ above land-surface datum, March 28, 1984, and March

17, 1983; lowest, $13.90 \mathrm{ft}$ above land-surface datum, June 10-11, 1985.

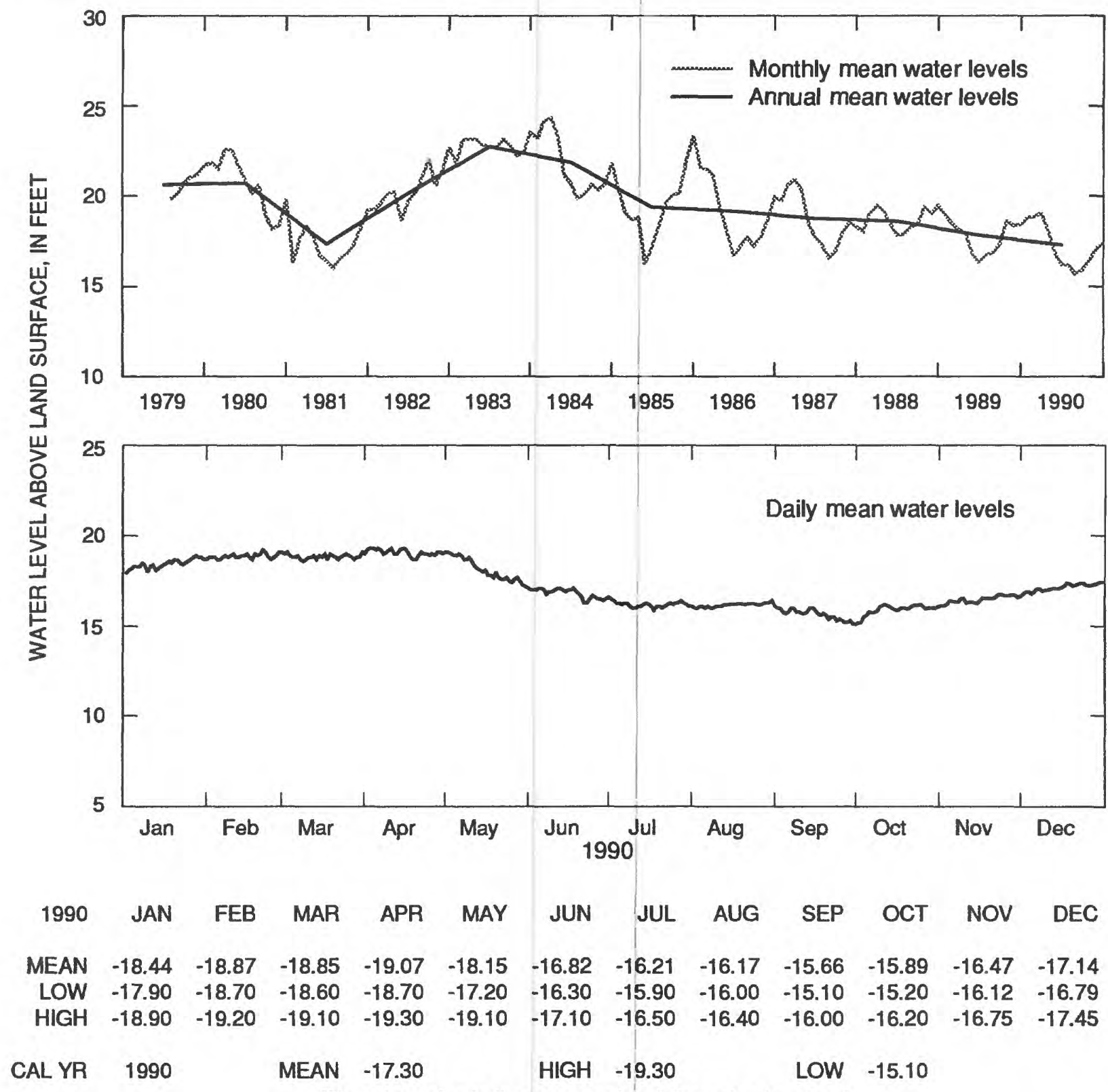

[Negative value indicates water level above land surface]

Figure 60.--Water level in observation well 33E027, Camden County. 
304942082213801 Local number, 27 E004.

LOCATION.--Lat 30'49'43", long 82²138", Hydrologic Unit 03110201, end of Georgia Highway 177, east of Stephen C.

Foster State Park.

Owner: U.S. Geological Survey, test well OK-9.

AQUIFER.--Upper Floridan aquifer.

WELL CHARACTERISTICS.--Drilled observation well, diameter 4 in., depth $700 \mathrm{ft}$, cased to $498 \mathrm{ft}$, open hole.

DATUM.--Altitude of land-surface datum is $116 \mathrm{ft}$.

Measuring point: Top of recorder shelf, $4.3 \mathrm{ft}$ above land-surface datum.

REMARKS.--Well drilled in May 1978 to replace USGS test well OK-8 (27E002).

PERIOD OF RECORD.--June 14, 1978, to January 26, 1979; January 1, 1980, to current year.

EXTREMES FOR PERIOD OF RECORD.--Highest water level, $62.30 \mathrm{ft}$ below land-surface datum, May 9, 1984; lowest,

$73.91 \mathrm{ft}$ below land-surface datum, October 7-8, 1990.

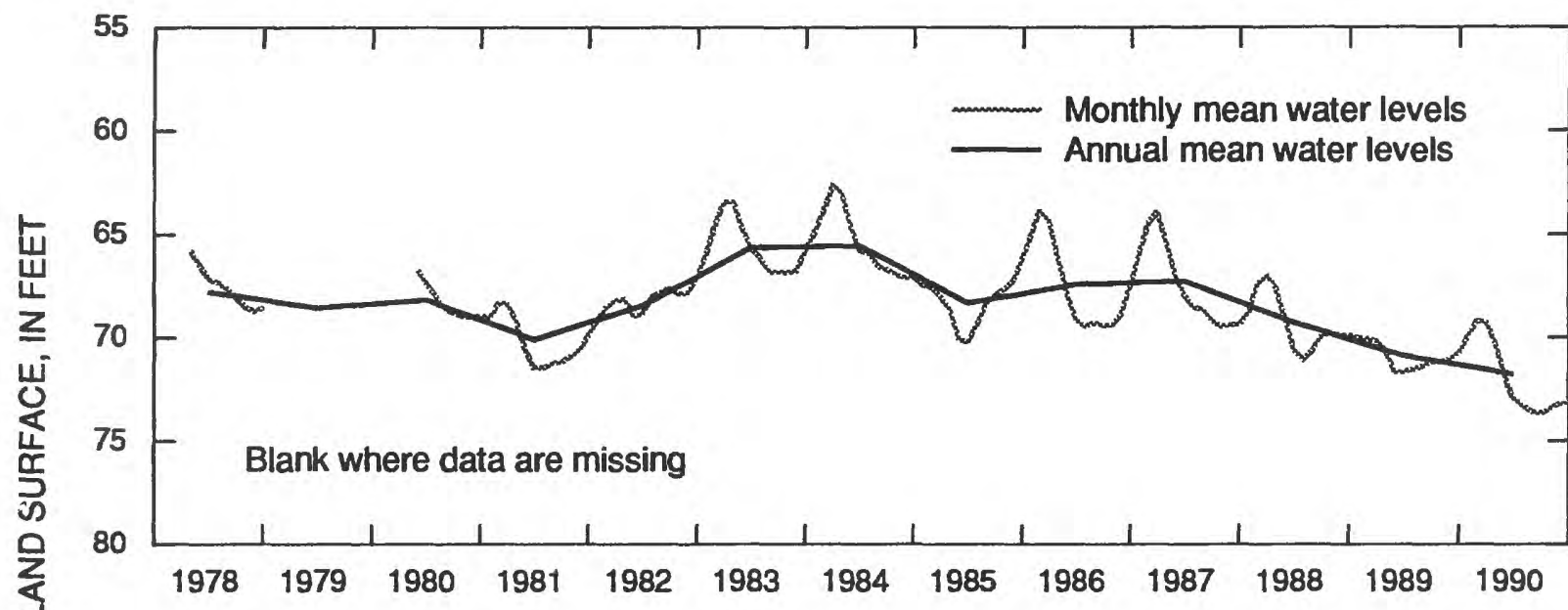

$\begin{array}{lllllllllllll}1990 & \text { JAN } & \text { FEB } & \text { MAR } & \text { APR } & \text { MAY } & \text { JUN } & \text { JUL } & \text { AUG } & \text { SEP } & \text { OCT } & \text { NOV } & \text { DEC } \\ \text { MEAN } & 70.72 & 69.92 & 69.18 & 69.27 & 70.27 & 71.74 & 72.90 & 73.28 & 73.58 & 73.66 & 73.42 & 73.19 \\ \text { LOW } & 71.22 & 70.21 & 69.39 & 69.59 & 71.03 & 72.46 & 73.11 & 73.37 & 73.80 & 73.91 & 73.61 & 73.38 \\ \text { HIGH } & 70.19 & 69.47 & 68.90 & 68.92 & 69.68 & 71.18 & 72.38 & 73.21 & 73.39 & 73.38 & 73.25 & 72.98 \\ \text { CAL YR } & 1990 & & \text { MEAN } & 71.77 & & \text { HIGH } & 68.90 & & \text { LOW } & 73.91 & & \end{array}$

Figure 61.--Water level in observation well 27E004, Charlton County. 


\section{Lower Floridan aquifer}

\section{Brunswick area}

The water level in the Lower Floridan aquifer is monitored in five wells in the Brunswick area, two of which are summarized in this report (fig. 62). Water levels in wells tapping the Lower Floridan aquifer in this area primarily are influenced by withdrawals from the Upper Floridan aquifer. This response is shown on the hydrographs for wells $34 \mathrm{H} 391$ (fig. 63) and 33J044 (fig. 64). A partial industrial shutdown in May, during which a major ground-water user stopped pumping from the Upper Floridan aquifer, resulted in sharp water-level rises in the two wells. The 1990 mean water level in well $34 \mathrm{H} 391$ was about $1.2 \mathrm{ft}$ lower than in 1989, and in well 33J044, was about $1.3 \mathrm{ft}$ lower than in 1989. Both wells show a downward water-level trend that began in 1983, similar to that observed in the Upper Floridan aquifer. (See hydrographs for wells 33H127, fig. 58, and 33H133, fig. 59.) A record-low daily mean water level was recorded in well $33 \mathrm{~J} 044$ (fig. 64) in September that was about $1.8 \mathrm{ft}$ lower than the previous record low. 


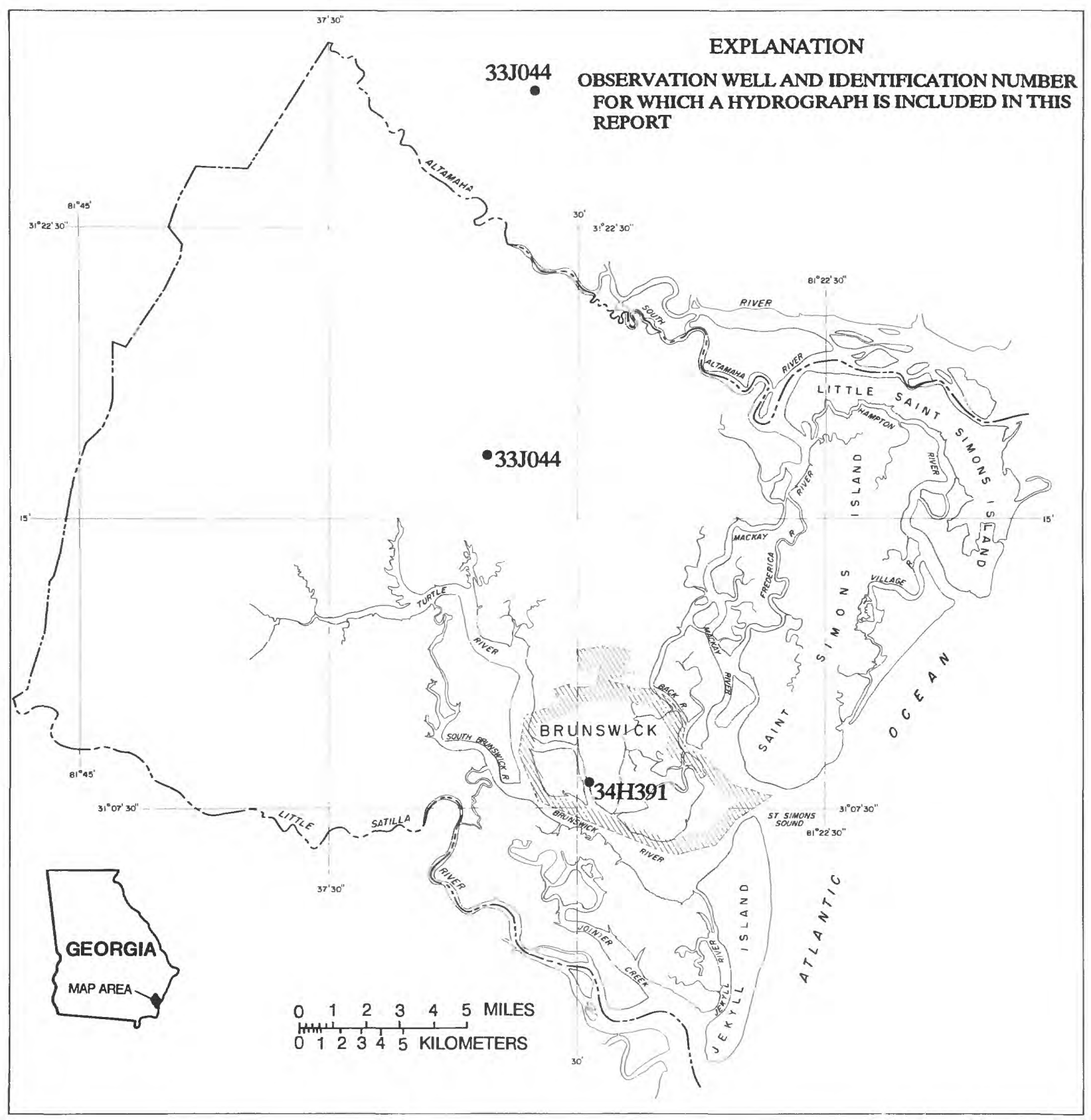

Figure 62.--Locations of observation wells completed in the Lower Floridan aquifer. 
310818081294201 Local number, 34H391.

LOCATION.--Lat $31^{\circ} 08^{\prime} 18^{\prime \prime}$, long 81 $29^{\prime} 42^{\prime \prime}$, Hydrologic Unit 03070203, located near intersection of Albemarle Street and Bay Street, in Brunswick.

Owner: U.S. Geological Survey, test well 16.

AQUIFER.--Lower Floridan aquifer.

WELL CHARACTERISTICS.--Drilled observation well, diameter $6 \mathrm{in}$., depth 1,150 ft, cased to $1,070 \mathrm{ft}$, open hole.

DATUM.-Altitude of land-surface datum is $7.13 \mathrm{ft}$.

Measuring point: Top of recorder shelf, $12.5 \mathrm{ft}$ above land-surface datum.

REMARKS.--Well pumped and sampled for analysis of chloride concentration semi-annually. Water levels for periods of missing record, February 28 to March 6, and March 17-22, were estimated.

PERIOD OF RECORD.--August 1975 to current year.

EXTREMES FOR PERIOD OF RECORD.--Highest water level, $11.65 \mathrm{ft}$ above land-surface datum, October 13-14, 1985; lowest, $2.96 \mathrm{ft}$ below land-surface datum, July 27, 1977.

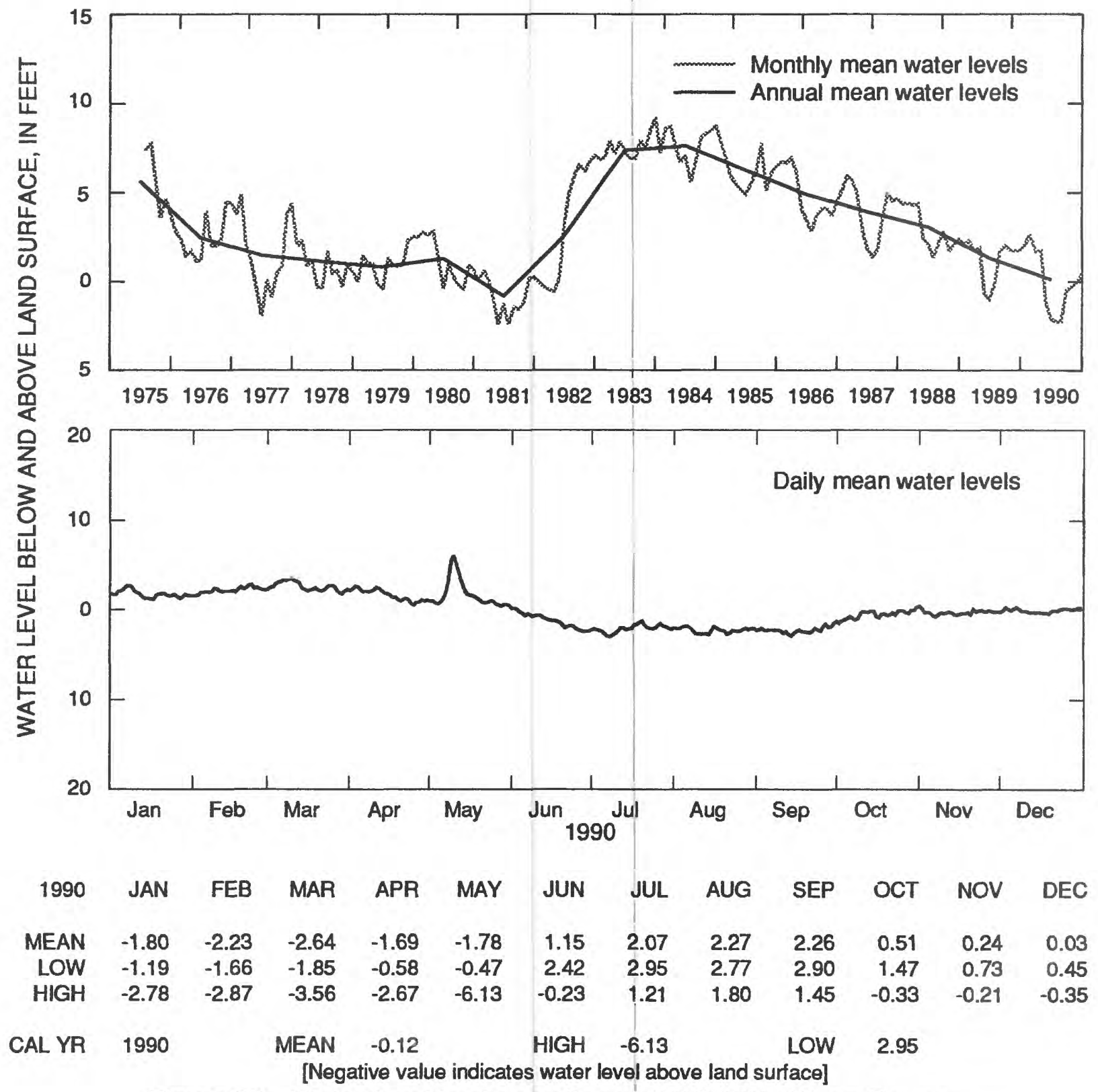

Figure 63.--Water level in observation well 34H391, Glynn County. 
311633081324001 Local number, 33J044.

LOCATION.--Lat $31^{\circ} 16^{\prime} 33^{\prime \prime}$ long 81 $32^{\prime} 40^{\prime \prime}$, Hydrologic Unit 03070203, 1.2 mi east of Sterling, off Georgia Highway 99 at the Georgia Pacific Company, Eastern Wood Products Division, Sterling Plant.

Owner: Georgia Pacific Co., USGS test well 27.

AQUIFER.--Lower Floridan aquifer.

WELL CHARACTERISTICS.-Drilled unused oil-test well converted to observation well, diameter 9 in., depth 2,260

$\mathrm{ft}$, cased to $1,079 \mathrm{ft}$, open hole.

DATUM.--Altitude of land-surface datum is $20 \mathrm{ft}$.

Measuring point: Top of recorder shelf, $9.5 \mathrm{ft}$ above land-surface datum.

REMARKS.--This is the Sterling oil-test well.

PERIOD OF RECORD.--May 1979 to current year.

EXTREMES FOR PERIOD OF RECORD.--Highest water level, $3.09 \mathrm{ft}$ above land-surface datum, October 13, 1985; lowest,

$8.44 \mathrm{ft}$ below land-surface datum, September 19, 1990.

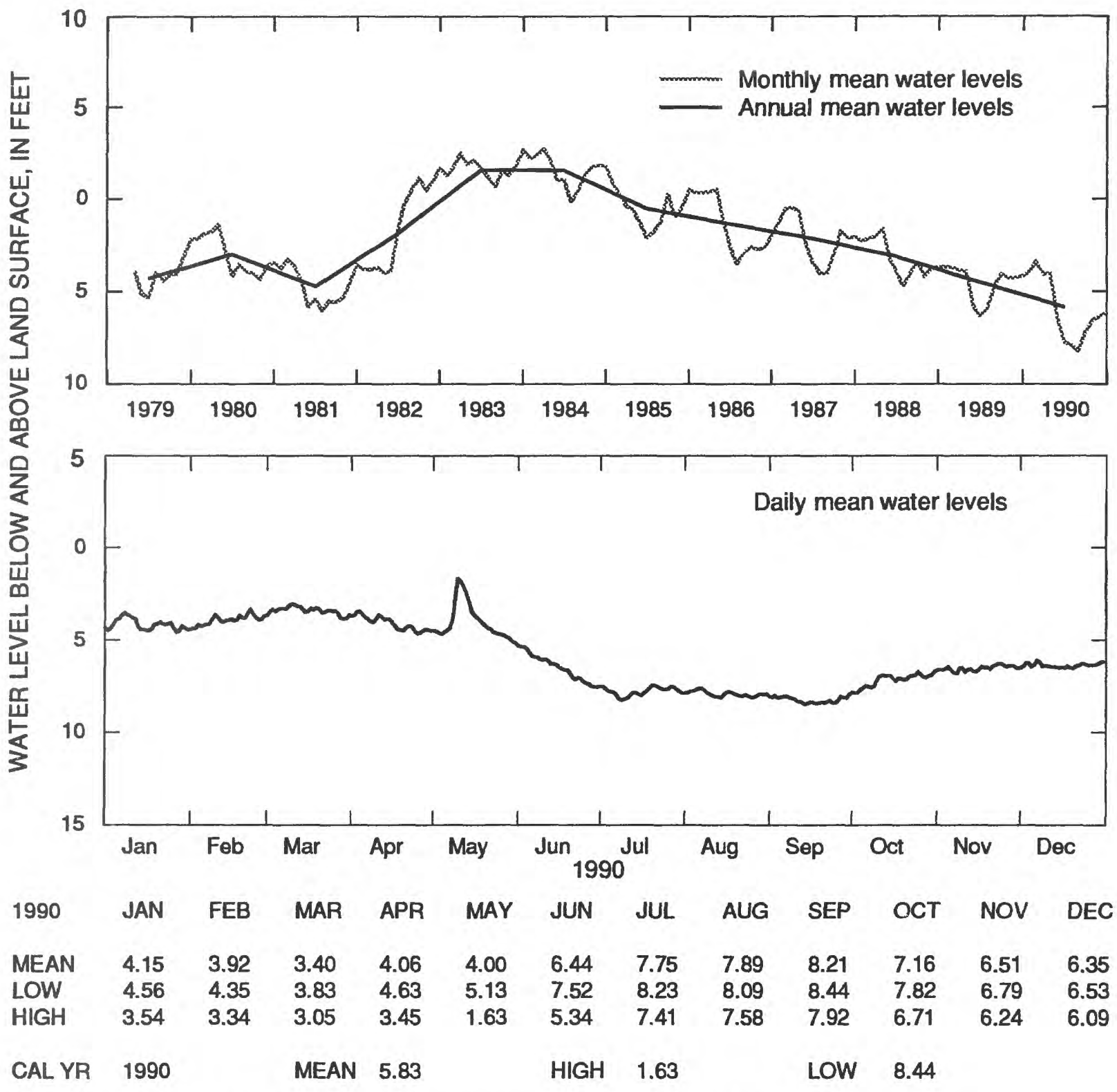

Figure 64.--Water level in observation well 33J044, Glynn County. 


\section{Claiborne Aquifer}

The water level in the Claiborne aquifer is monitored in 22 wells, 11 of which are summarized in this report (fig. 65). The water level in the aquifer is affected primarily by precipitation and by local and regional pumping. During 1985, the aquifer supplied about $62 \mathrm{Mgal} / \mathrm{d}$, primarily for municipal, industrial, and agricultural uses (Pierce and Kundell, 1990, p. 219). The water level generally is highest following the winter and spring rainy seasons, and lowest in the fall following the summer irrigation season.

During October 1990, water-level measurements from 76 wells tapping the Claiborne aquifer were used to construct a water-level map (West, 1991) (fig. 65). A cone of depression is centered at Albany, and is the result of pumping in that area. The configuration of the water-level surface showed little change from that of 1989 (Peck and others, 1990, fig. 63).

The 1990 mean water levels in wells $06 \mathrm{~K} 010$ (fig. 66), 09G001 (fig. 67), 09M009 (fig. 68), 11K002 (fig. 69), 11P015 (fig. 70), and 15R007 (fig. 71) were from about 0.2 to $1.7 \mathrm{ft}$ higher than in 1989. This rise in water levels continued upward trends that began in 1986 in well 06K010 (fig. 66), and in 1988 in wells 09G001 (fig. 67), $09 \mathrm{M} 009$ (fig. 68), and 15R007 (fig. 71). In wells 11K002 (fig. 69) and 11P015 (fig. 70), this rise in water level reversed downward trends that began in 1984 and 1987, respectively. Record-high daily mean water levels were recorded in April in well 06K010 (fig. 66) and in January in well $09 \mathrm{M} 009$ (fig. 68) that were about 2.0 and $0.4 \mathrm{ft}$ higher than the previous record highs, respectively. These water-level rises were attributed to decreased regional pumping as a result of above-normal precipitation (see precipitation graph for Albany, fig. 5).

Near the cone of depression at Albany (fig. 65), the annual mean water levels in wells $11 \mathrm{L001}$ (fig. 72), 12L019 (fig. 73), 13L011 (fig. 74), and 13M005 (fig. 75) were from about 0.6 to $2.9 \mathrm{ft}$ lower in 1990 than in 1989. In wells $11 \mathrm{LO01}$ (fig. 72) and 12L019 (fig. 73), the water-level decline reversed an upward trend that began in 1986. The water-level decline continued downward trends in wells $13 \mathrm{~L} 011$ (fig. 74) and 13M005 (fig. 75) that began in 1988 and 1987, respectively. The 1990 annual mean water level in well 14P015 (fig. 76) was about $6.1 \mathrm{ft}$ lower than in 1989; this water-level decline reversed a slight upward trend that began in 1986. A record-low daily mean water level was recorded in well 14P015 (fig. 76) in September that was about $7.8 \mathrm{ft}$ lower than the previous record low. These declines may be attributed to increased pumping as a result of below-normal rainfall. 


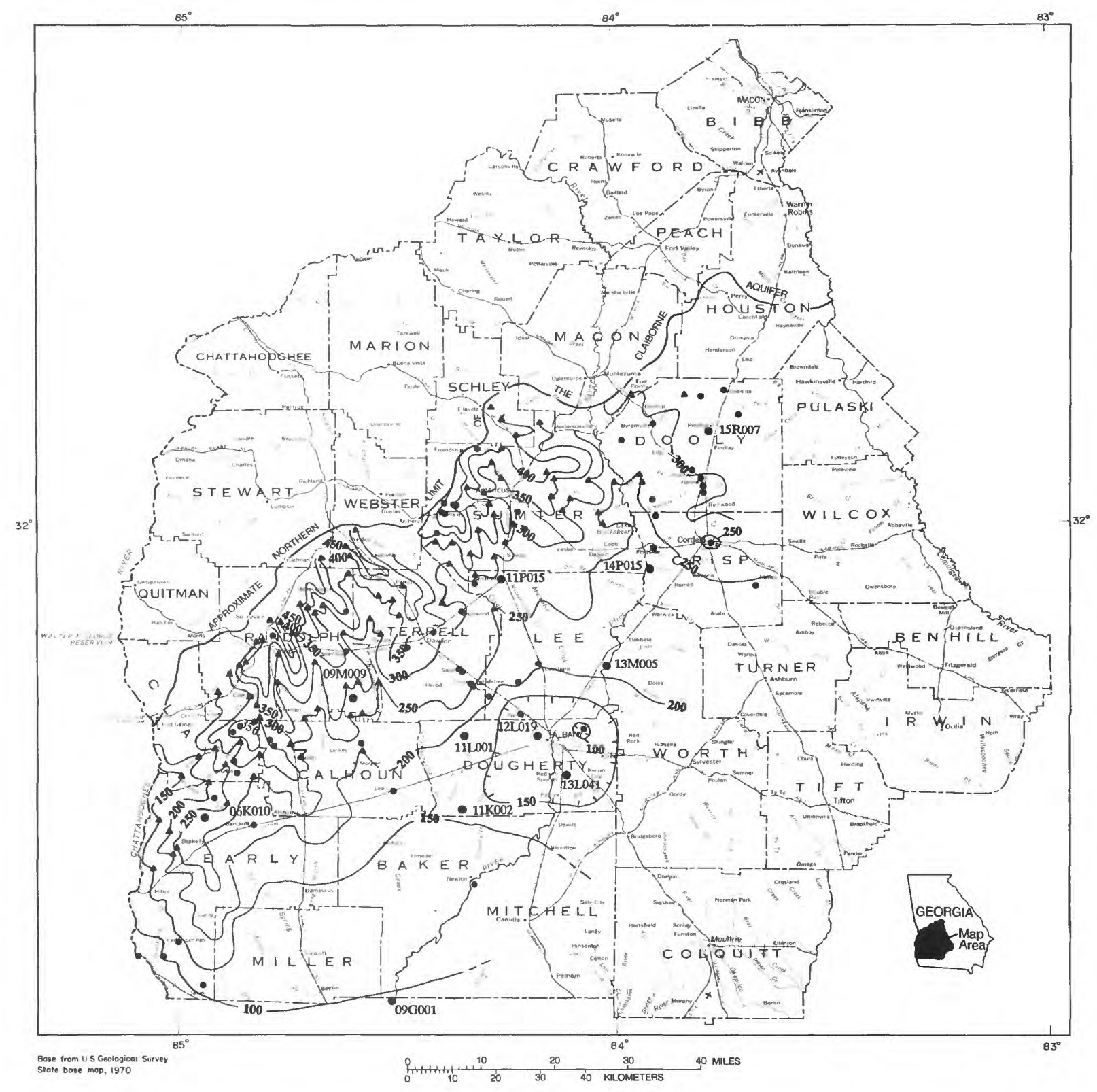

EXPLANATION

- POTENTIOMETRIC CONTOUR--Shows altitude at which water level would have stood in tights
cased wells. Dashed where approximately located. Hachures indicate depressions. Contour
interval 50 feet. Datum is sea level
DATA POINT
Ground water--Altitude of water level in well
Surface water--Location where stream and water-table altitudes are coincident. Altitude of
stream surface is extrapolated from topographic contour map
Observation well and identification number for which a hydrograph is included in this report

Figure 65.--Water level and locations of observations wells completed in the Claiborne aquifer, November 1990. From West (1991). 
312827084551503 Local number, 06K010.

LOCATION.--Lat $31^{\circ} 28^{\prime} 24^{\prime \prime}$, long $84^{\circ} 55^{\prime} 09^{\prime \prime}$, Hydrologic Unit 03130004, easternmost of two recorder wells, $900 \mathrm{ft}$ north of the pool at Kolomoki Mounds State Park, 4.2 mi north of the city limits of Blakely, on Kolomoki Road. Owner: Georgia Geologic Survey, Kolomoki Mounds State Park test well 3.

AQUIFER.-Claibome.

WELL CHARACTERISTICS.--Drilled observation well, diameter 4 in., depth $140 \mathrm{ft}$, cased to $120 \mathrm{ft}$, screen to $140 \mathrm{ft}$.

DATUM.-Altitude of land-surface datum is $310 \mathrm{ft}$.

Measuring point: Top of recorder shelf, $3.56 \mathrm{ft}$ above land-surface datum.

REMARKS.-Well pumped and redeveloped August 8, 1989.

PERIOD OF RECORD.--August 31, 1984, to current year.

EXTREMES FOR PERIOD OF RECORD.--Highest water level, $73.11 \mathrm{ft}$ below land-surface datum, April 3, 1990; lowest,

$77.35 \mathrm{ft}$ below land-surface datum, November 14, 1986.

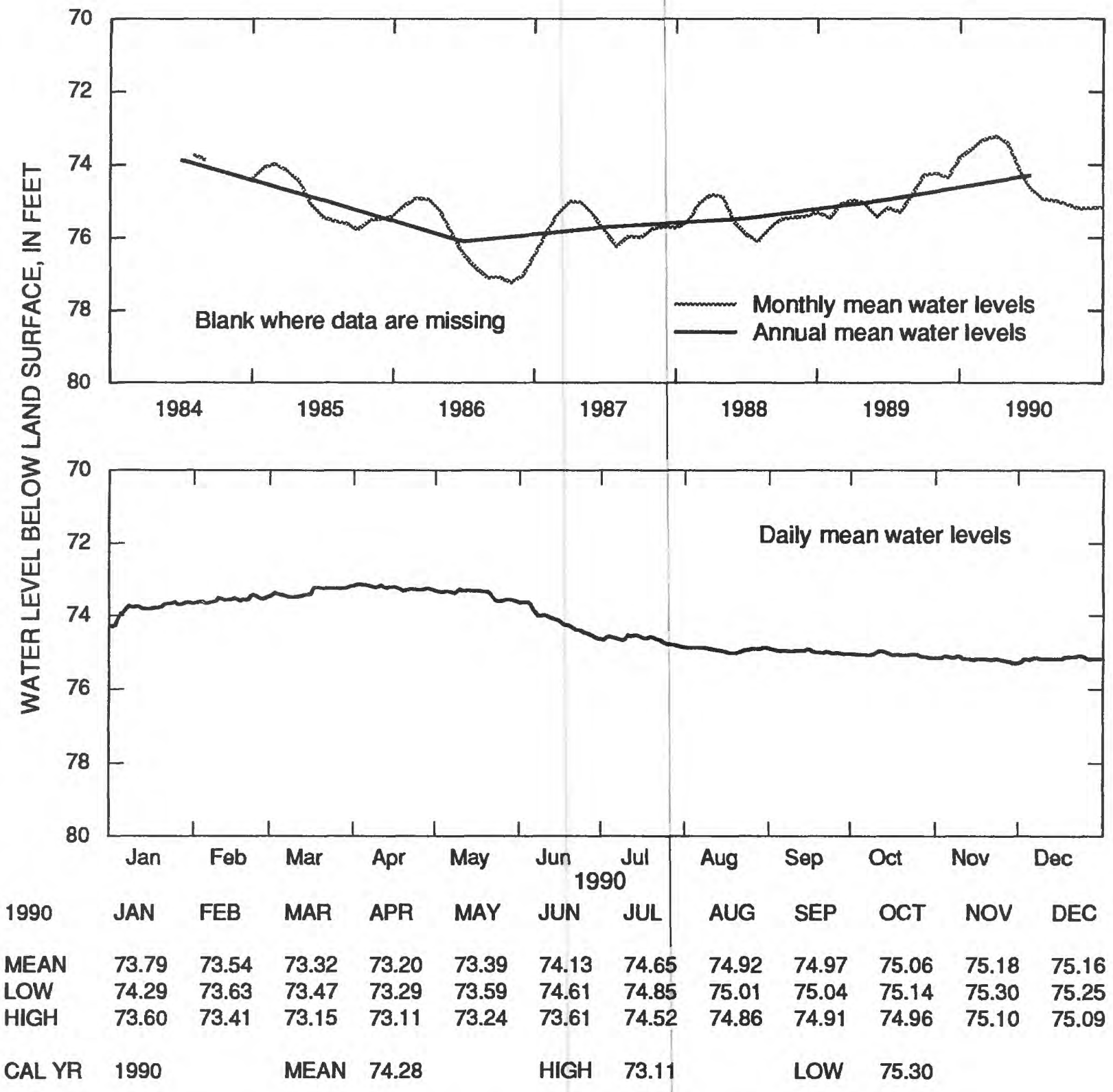

Figure 66.--Water level in observation well 06K010, Early County. 
310428084310501 Local number, 09 G001.

LOCATION.-Lat $31^{\circ} 04^{\prime} 28^{\prime \prime}$, long $84^{\circ} 31^{\prime} 05^{\prime \prime}$, Hydrologic Unit 03130008 , westernmost of two recorder wells, 2,500 ft east of Georgia Highway 253, 0.2 mi south of the Decatur-Baker County line.

Owner: Earl Nichols, U.S. Geological Survey test well DP-4.

AQUIFER.--Claiborne.

WELL CHARACTERISTICS.--Drilled observation well, diameter 4 in., depth $455 \mathrm{ft}$, cased to $382 \mathrm{ft}$, open hole.

DATUM.-Altitude of land-surface datum is $145 \mathrm{ft}$.

Measuring point: Top of recorder shelf, $3.1 \mathrm{ft}$ above land-surface datum.

REMARKS.-Well pumped and redeveloped August 10, 1989. Water levels for period of missing record, September 7-14,

September 24-30, and October 1-21, were estimated

PERIOD OF RECORD.--February 20,1980, to current year.

EXTREMES FOR PERIOD OF RECORD.--Highest water level, $41.3 \mathrm{ft}$ below land-surface datum, April 8, 1980; lowest,

56.41 below land-surface datum, October 20, 1981.

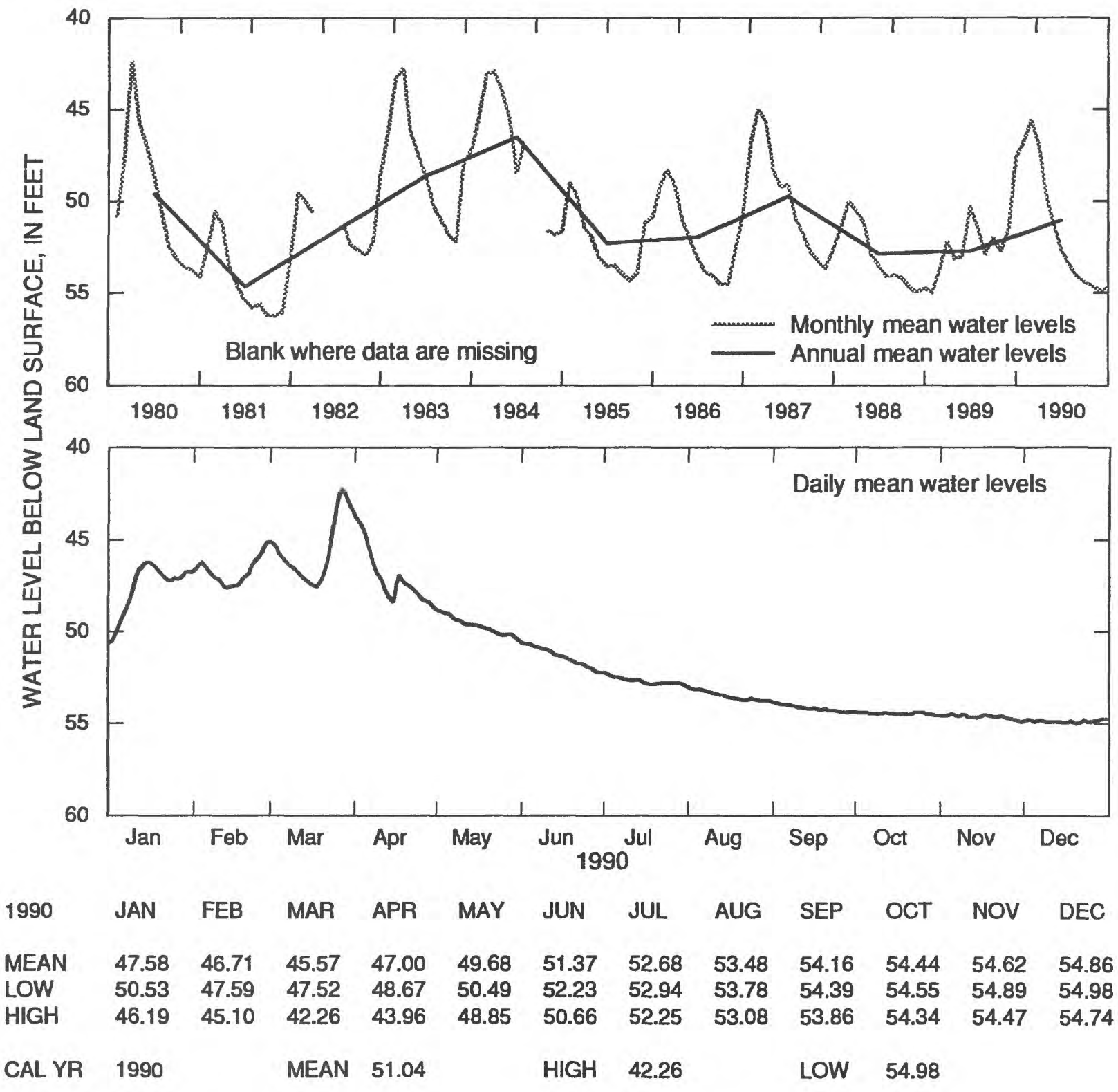

Figure 67.--Water level in observation well 09G001, Decatur County. 
313953084361201 Local number, 09M009.

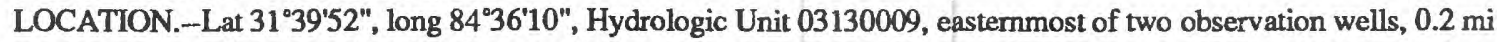
east of Georgia Highway 41,7.2 mi south of the intersection of U.S. Highway 82 and Georgia Highway 41 in Shellman.

Owner: C.T. Martin, test well 1.

AQUIFER.--Claibome.

WELL CHARACTERISTICS.--Drilled observation well, diameter 4 in., depth $94 \mathrm{ft}$ cased to $77 \mathrm{ft}$, screen to $94 \mathrm{ft}$.

DATUM.--Altitude of land-surface datum is $322 \mathrm{ft}$.

Measuring point: Top of recorder shelf, $3.27 \mathrm{ft}$ above land-surface datum.

REMARKS.--Well pumped and redeveloped August 8, 1989.

PERIOD OF RECORD.--September 14, 1984, to current year.

EXTREMES FOR PERIOD OF RECORD.--Highest water level, $24.98 \mathrm{ft}$ below land-surface datum. January 12, 1990; lowest,

$30.50 \mathrm{ft}$ below land-surface datum, November 3, 1986.

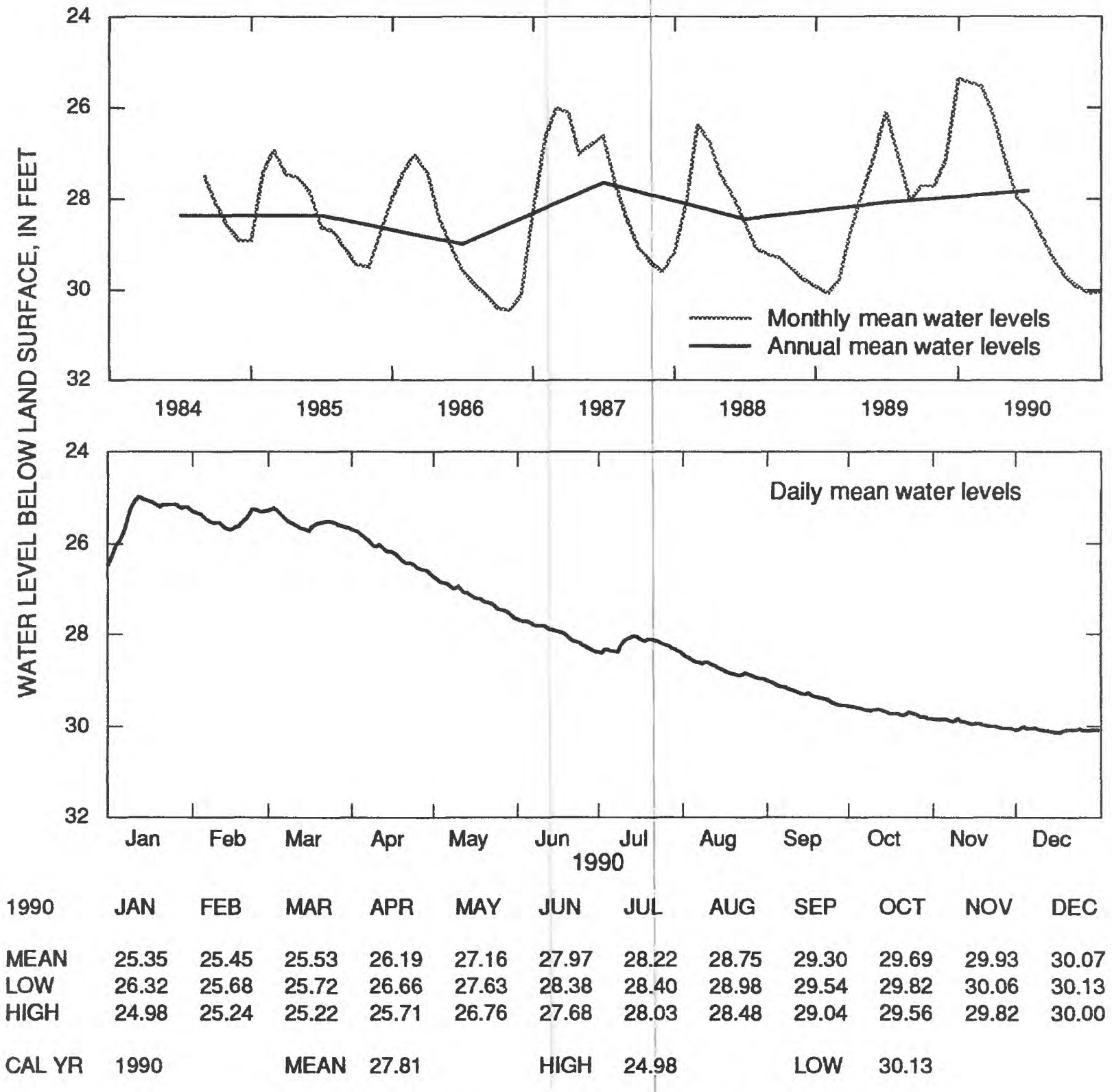

Figure 68.--Water level in observation well 09M009, Randolph County. 
312654084210102 Local number, $11 \mathrm{~K} 002$.

LOCATION.--Lat $31^{\circ} 26^{\prime} 54^{\prime \prime}$, long $84^{\circ} 21^{\prime} 01^{\prime \prime}$, Hydrologic Unit 03130008 , westernmost of two recorder wells, $50 \mathrm{ft}$ east of logging road, $0.65 \mathrm{mi}$ west and $0.65 \mathrm{mi}$ south of main gate into St. Joe Paper Company woodland on Tarva Road, $3.6 \mathrm{mi}$ south of Georgia Highway 62, about $12 \mathrm{mi}$ west of Albany.

Owner: U.S. Geological Survey, test well 11.

AQUIFER.--Claibome.

WELL CHARACTERISTICS.--Drilled observation well, diameter 4 in., depth $320 \mathrm{ft}$, cased to $300 \mathrm{ft}$, screen to $320 \mathrm{ft}$.

DATUM.-Altitude of land-surface datum is $183.5 \mathrm{ft}$.

Measuring point: Top of recorder shelf, $3.0 \mathrm{ft}$ above land-surface datum.

REMARKS.--Borehole geophysical survey conducted March 11, 1980.

PERIOD OF RECORD.--May 16, 1979, to current year.

EXTREMES FOR PERIOD OF RECORD.--Highest water level, $22.11 \mathrm{ft}$ below land-surface datum, June 1, 1979; lowest, $28.04 \mathrm{ft}$ below land-surface datum, December 24, 1981.

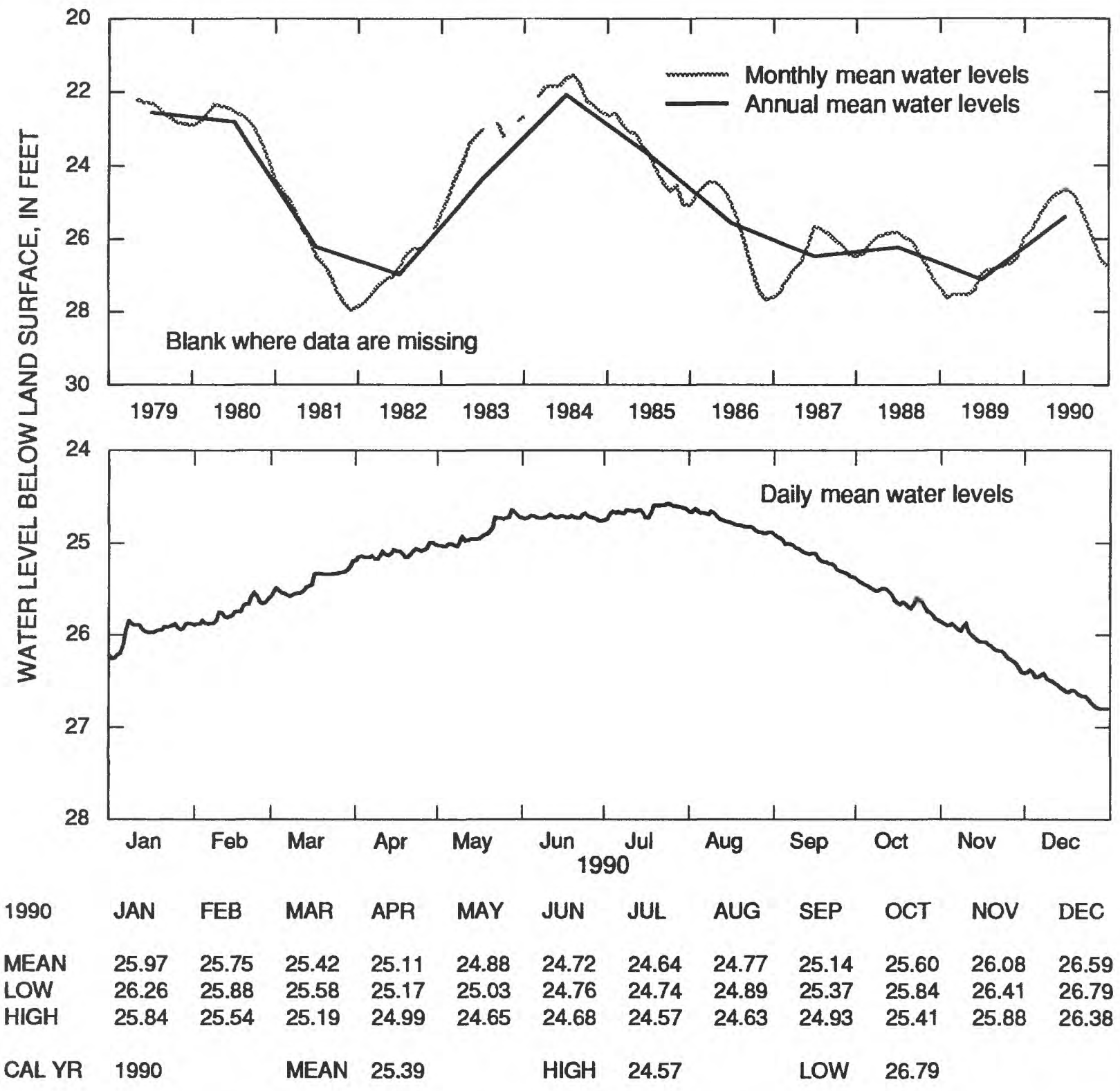

Figure 69.--Water level in observation well 11K002, Dougherty County. 
315353084192502 Local number, 11P015.

LOCATION.--Lat 31 $53^{\prime} 50^{\prime \prime}$, long 84'19'21", Hydrologic Unit 03130007 , eastemmost of two observation wells, $4.2 \mathrm{mi}$ west of the intersection of County Road 53 and U.S. Highway 19 in Smithville, $700 \mathrm{ft}$ south of County Road 53.

Owner: Pete Long, test well 2.

AQUIFER.--Claibome.

WELL CHARACTERISTICS.--Drilled observation well, diameter 6 in., depth $151 \mathrm{ft}$, cased to $111 \mathrm{ft}$, screen to $151 \mathrm{ft}$.

DATUM.-Altitude of land-surface datum is $338 \mathrm{ft}$.

Measuring point: Top of recorder shelf, $3.2 \mathrm{ft}$ above land-surface datum .

REMARKS.--Well pumped and redeveloped August 7, 1989. Water levels for periods of missing record, February 13-27, were estimated.

PERIOD OF RECORD.--September 14, 1984, to current year.

EXTREMES FOR PERIOD OF RECORD.--Highest water level, $35.89 \mathrm{ft}$ below land-surface datum, September 14, 1984; lowest, $39.66 \mathrm{ft}$ below land-surface datum, October 28, 1986.

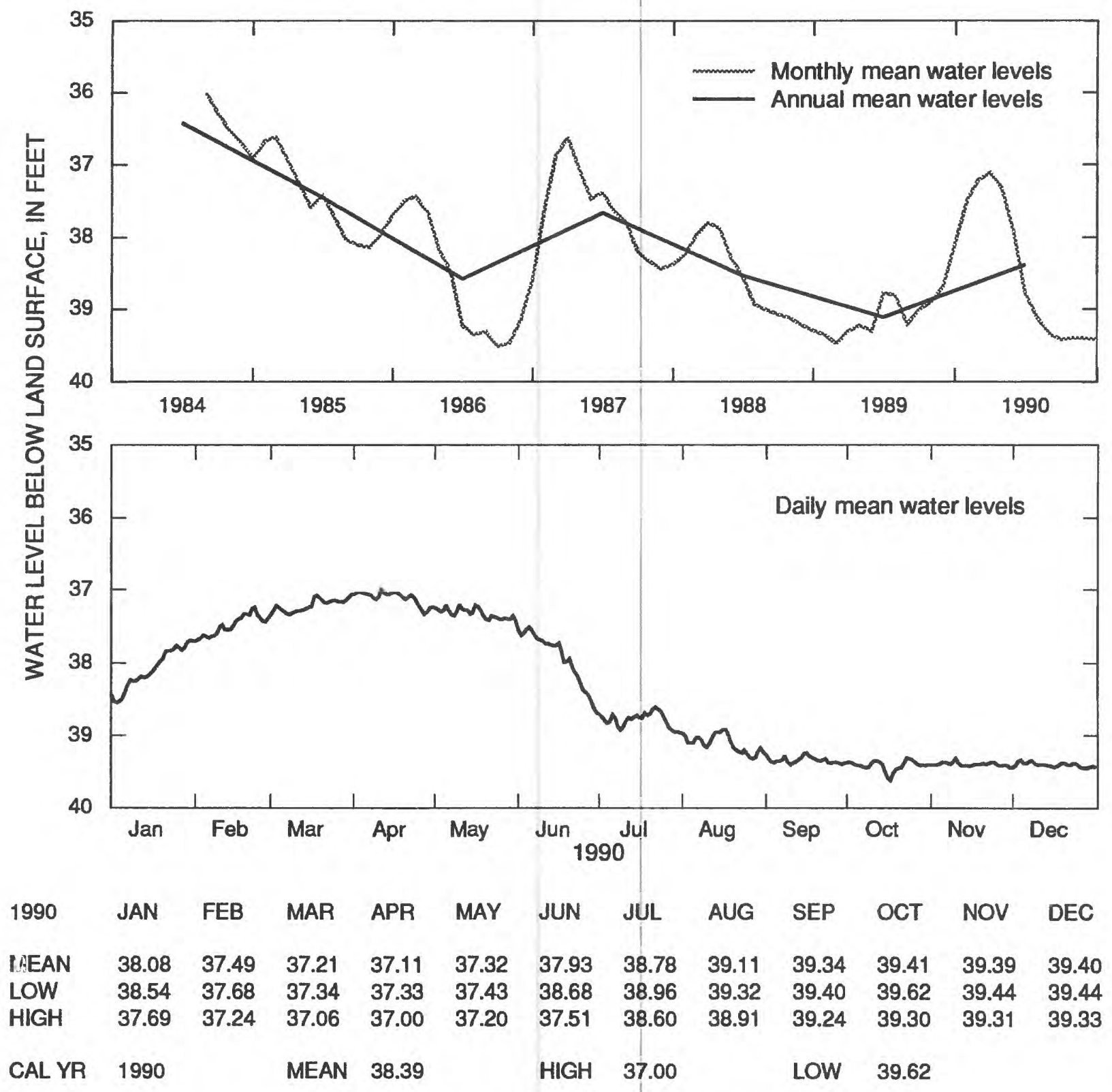

Figure 70.--Water level in observation well 11P015, Lee County. 
321110083462701 Local number, $15 R 007$.

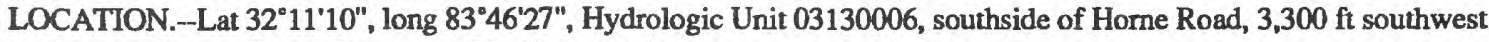
of intersection of Horne Road and U.S. Highway 41.

Owner: William Horne.

AQUIFER.--Claiborne.

WELL CHARACTERISTICS.--Drilled observation well, diameter 6 in., depth $330 \mathrm{ft}$, cased to $241 \mathrm{ft}$, screen from

241 to $309 \mathrm{ft}$, cased from 309 to $330 \mathrm{ft}$.

DATUM.--Altitude of land-surface datum is $412 \mathrm{ft}$.

Measuring point: Top of recorder shelf, $3.0 \mathrm{ft}$ above land-surface datum.

REMARKS.--Borehole geophysical survey conducted May 6, 1982. Aquifer test conducted May 21, 1982.

PERIOD OF RECORD.--October 1, 1984, to current year.

EXTREMES FOR PERIOD OF RECORD.--Highest water level, $76.71 \mathrm{ft}$ below land-surface datum, April 17, 1987; lowest,

$96.25 \mathrm{ft}$ below land-surface datum, August 22, 1986.

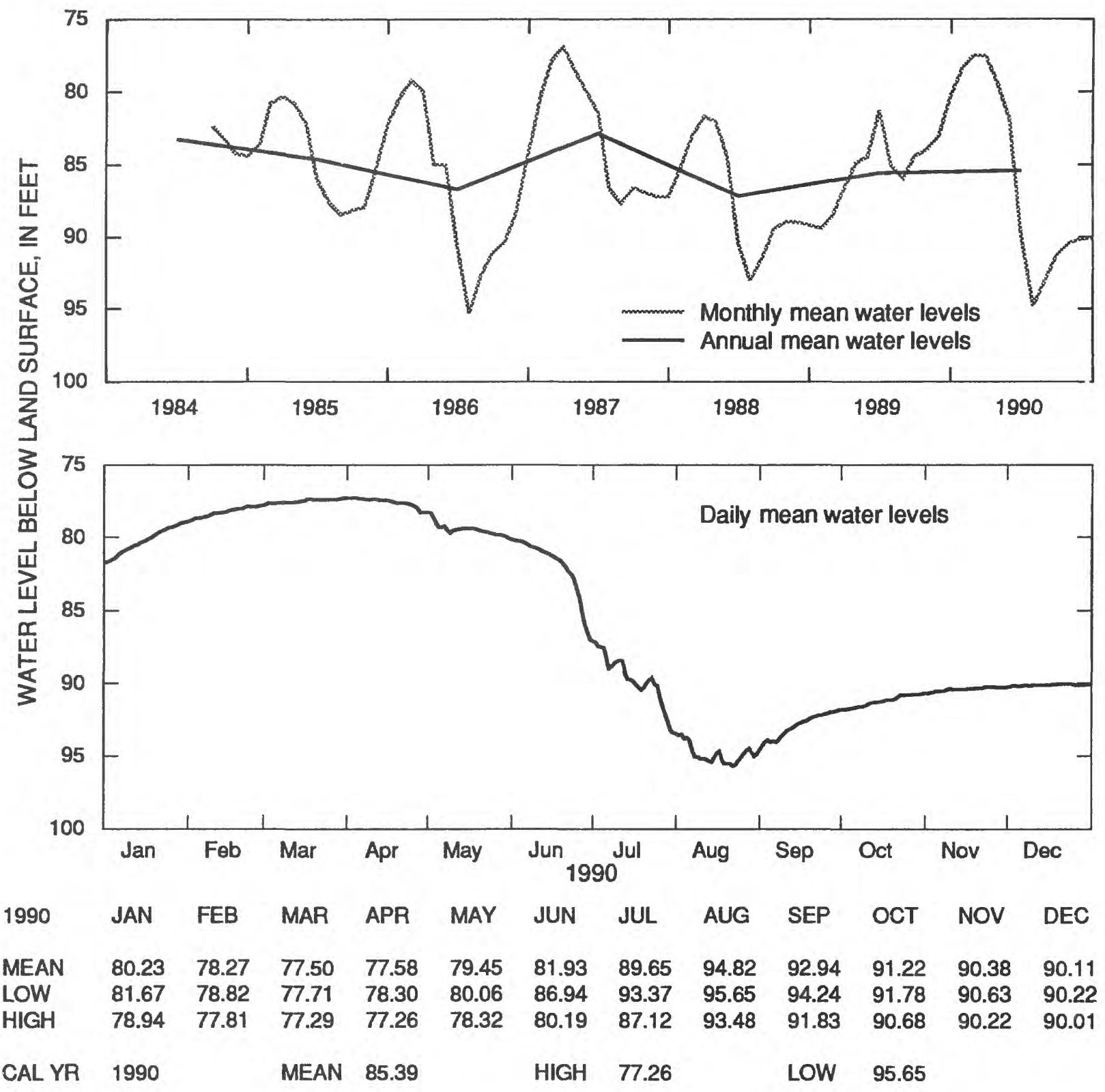

Figure 71.--Water level in observation well 15R007, Dooly County. 
313530084203202 Local number, $11 \mathrm{~L} 001$.

LOCATION.--Lat $31^{\circ} 35^{\prime} 30^{\prime \prime}$, long $84^{\circ} 20^{\prime} 34^{\prime \prime}$, Hydrologic Unit 03130008, Tallahassee Plantation, 1.3 mi north of Georgia

Highway 234, 10.4 mi west of Albany.

Owner: U.S. Geological Survey, test well 4.

AQUIFER.--Claibome.

WELL CHARACTERISTICS.--Drilled observation well, diameter 4 in., depth $251 \mathrm{ft}$, cased to $233 \mathrm{ft}$, screen to $251 \mathrm{ft}$.

DATUM.--Altitude of land-surface datum is $220 \mathrm{ft}$.

Measuring point: Top of recorder shelf, $3.0 \mathrm{ft}$ above land-surface datum.

REMARKS.--Well pumped and redeveloped August 14, 1988. Water levels for periods of missing record, August 10-24,

were estimated.

PERIOD OF RECORD.--March 1978 to current year.

EXTREMES FOR PERIOD OF RECORD.--Highest water level, $12.11 \mathrm{ft}$ below land-surface datum, June 5-6, 1978; lowest,

$34.75 \mathrm{ft}$ below land-surface datum, October 19-20, 1986.

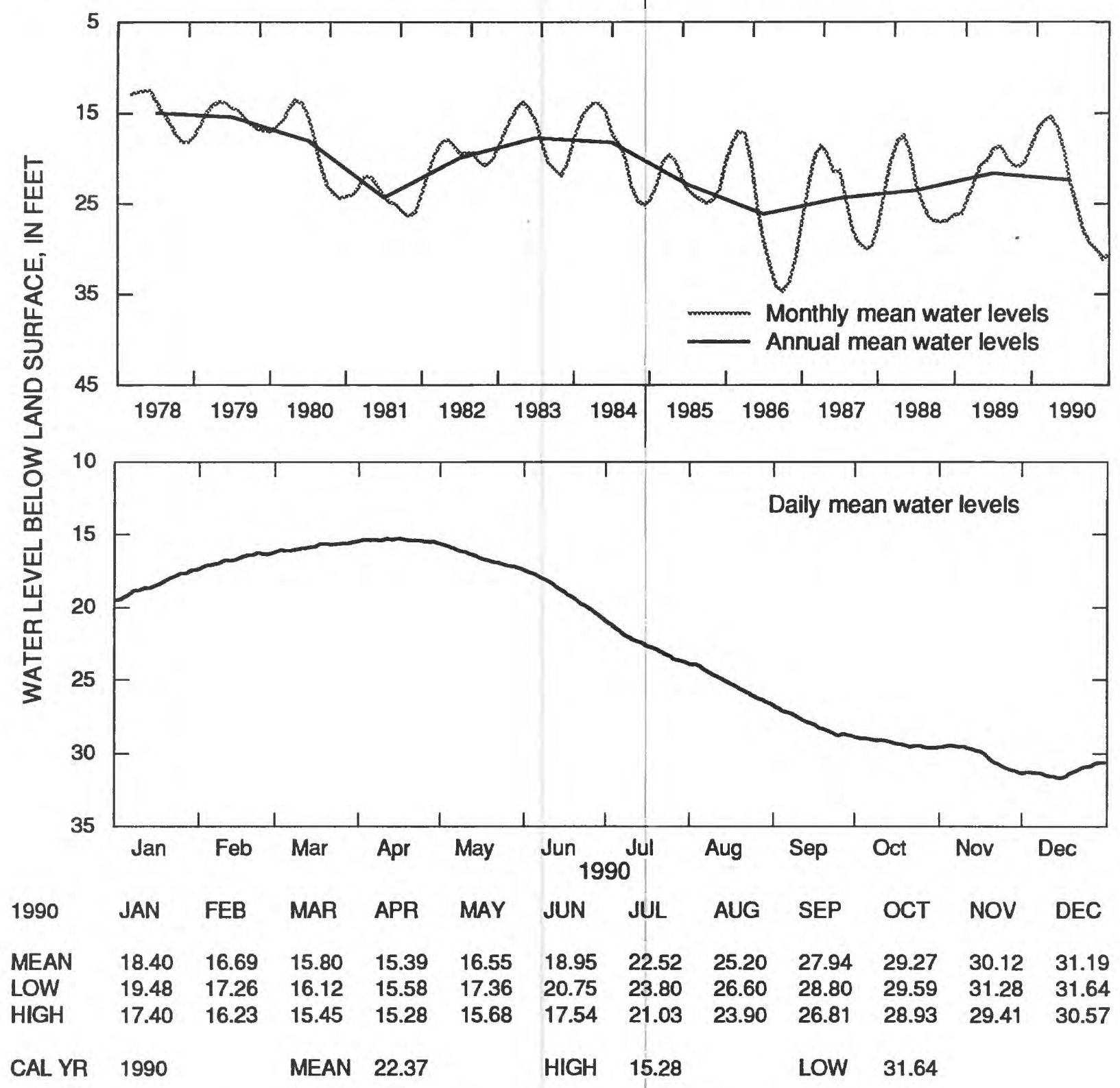

Figure 72.--Water level in observation well 11L001, Dougherty County. 
313534084103001 Local number, 12 L019.

LOCATION.-Lat $31^{\circ} 35^{\prime} 36^{\prime \prime}$, long $84^{\circ} 10^{\prime} 30^{\prime \prime}$, Hydrologic Unit 03130008, located in southwest corner of park, $500 \mathrm{ft}$ east of intersection of Slappey Drive and Fifth Avenue.

Owner: U.S. Geological Survey, test well 5.

AQUIFER.--Claiborne.

WELL CHARACTERISTICS.--Drilled observation well, diameter 4 in., depth $257 \mathrm{ft}$, cased to $241 \mathrm{ft}$, screen to $257 \mathrm{ft}$.

DATUM.-Altitude of land-surface datum is $198 \mathrm{ft}$.

Measuring point: Top of recorder shelf, $3.0 \mathrm{ft}$ above land-surface datum.

REMARKS.--Well pumped and redeveloped August 15, 1988.

PERIOD OF RECORD.--March 1978 to current year.

EXTREMES FOR PERIOD OF RECORD.--Highest water level, $63.61 \mathrm{ft}$ below land-surface datum, April 4, 1990; lowest,

$99.53 \mathrm{ft}$ below land-surface datum, August 1-2, 1978.

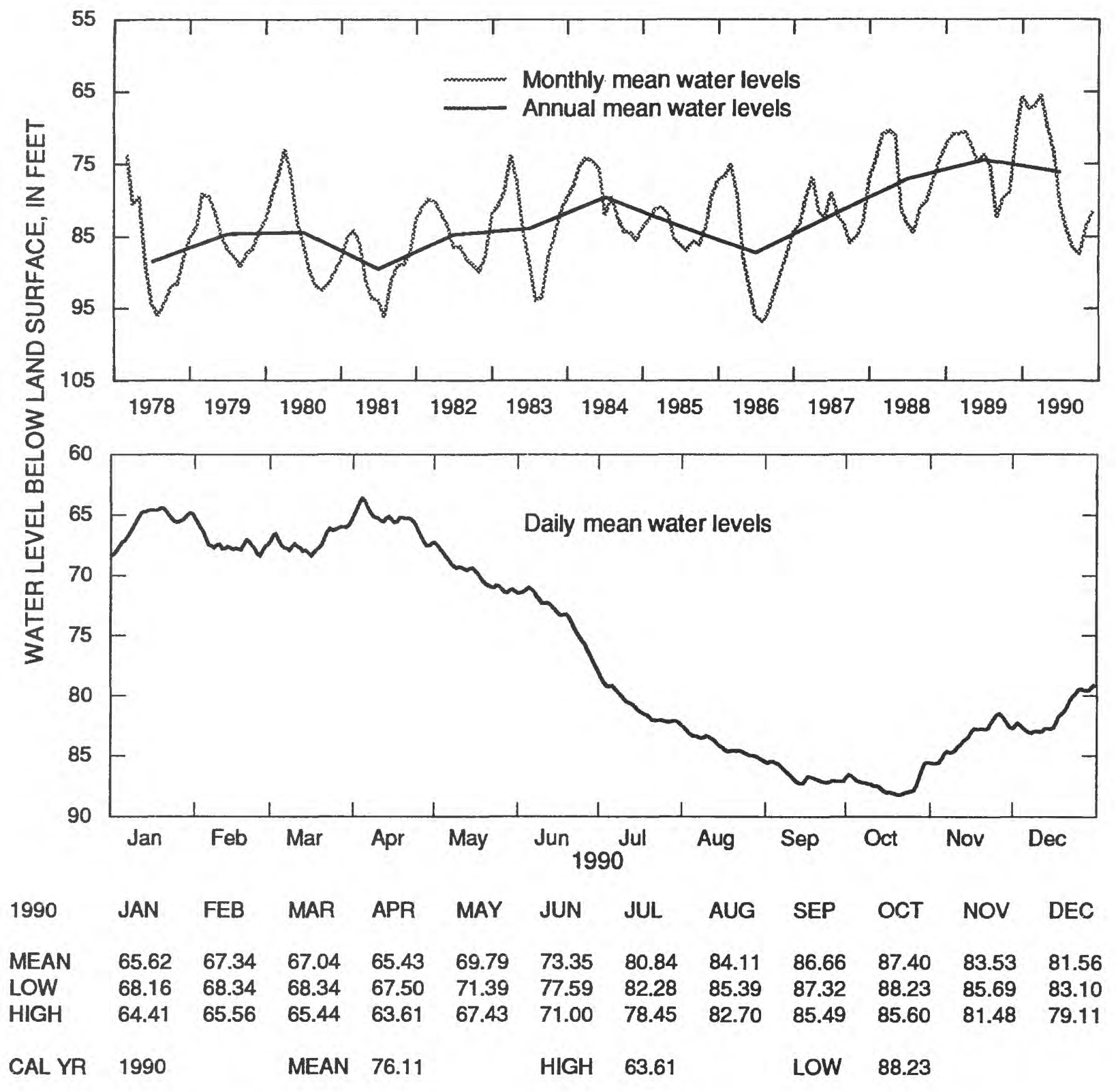

Figure 73.-Water level in observation well 12L019, Dougherty County. 
313105084064301 Local number, 13 L011.

LOCATION.--Lat $31^{\circ} 31^{\prime} 05^{\prime \prime}$, long 84 $06^{\prime} 43^{\prime \prime}$, Hydrologic Unit 03130008, about $6.5 \mathrm{mi}$ southeast of Albany, east of U.S. Highway 19 on dirt road, 0.1 mi north of School Bus Road.

Owner: U.S. Geological Survey, test well 2.

AQUIFER.-Claibome.

WELL CHARACTERISTICS.--Drilled observation well, diameter 4 in., depth $418 \mathrm{ft}$, cased to $398 \mathrm{ft}$, screen to $418 \mathrm{ft}$.

DATUM.--Altitude of land-surface datum is $195 \mathrm{ft}$.

Measuring point: Top of recorder shelf, $3.0 \mathrm{ft}$ above land-surface datum.

REMARKS.--Well pumped and redeveloped August 16, 1988.

PERIOD OF RECORD.-June 1977 to current year.

EXTREMES FOR PERIOD OF RECORD.--Highest water level, $60.01 \mathrm{ft}$ below land-surface datum, April 5, 1978; lowest, $95.00 \mathrm{ft}$ below land-surface datum, August 9-11, 1981.

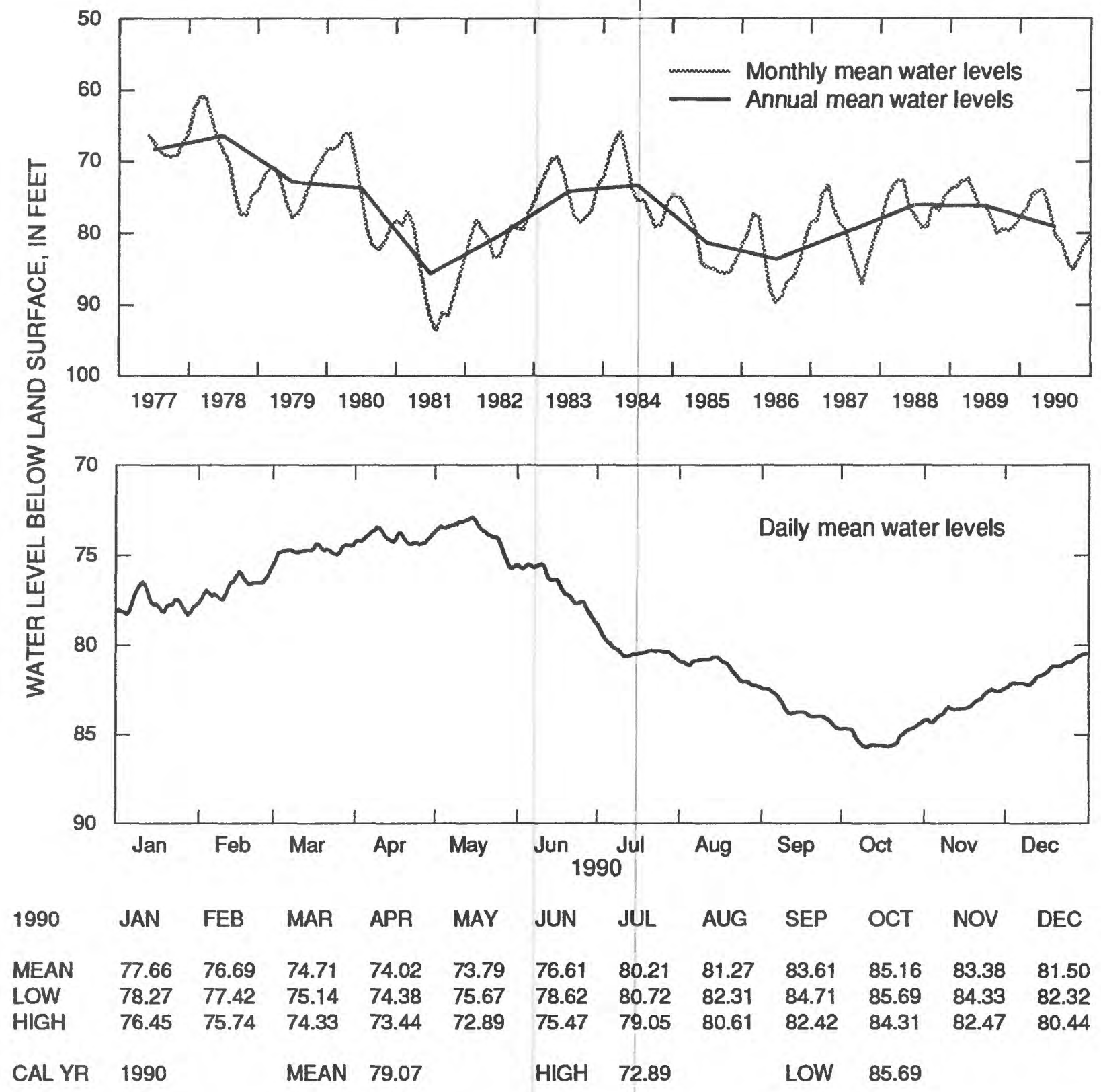

Figure 74.--Water level in observation well 13L011, Dougherty County. 
314330084005401 Local number, $13 \mathrm{M} 005$.

LOCATION.-Lat 31"43'30", long 8400'54", Hydrologic Unit 03130006, easternmost of three observation wells, $50 \mathrm{ft}$ north of Georgia Highway 32, 1,400 ft east of the Flint River, 1.7 mi east of the intersection of Georgia Highways 32 and 91.

Owner: U.S. Geological Survey, test well DP-7.

AQUIFER.--Claiborne.

WELL CHARACTERISTICS.--Drilled observation well, diameter 6 in., depth $345 \mathrm{ft}$, cased to $330 \mathrm{ft}$, screen to $345 \mathrm{ft}$.

DATUM.--Altitude of land-surface datum is $230 \mathrm{ft}$.

Measuring point: Top of recorder shelf, $3.13 \mathrm{ft}$ above land-surface datum.

REMARKS.-Borehole geophysical survey conducted March 16, 1982.

PERIOD OF RECORD.--April 22, 1980, to current year.

EXTREMES FOR PERIOD OF RECORD.--Highest water level, $2.89 \mathrm{ft}$ below land-surface datum, May 29, 1980; lowest,

$23.37 \mathrm{ft}$ below land-surface datum July $28,1981$.

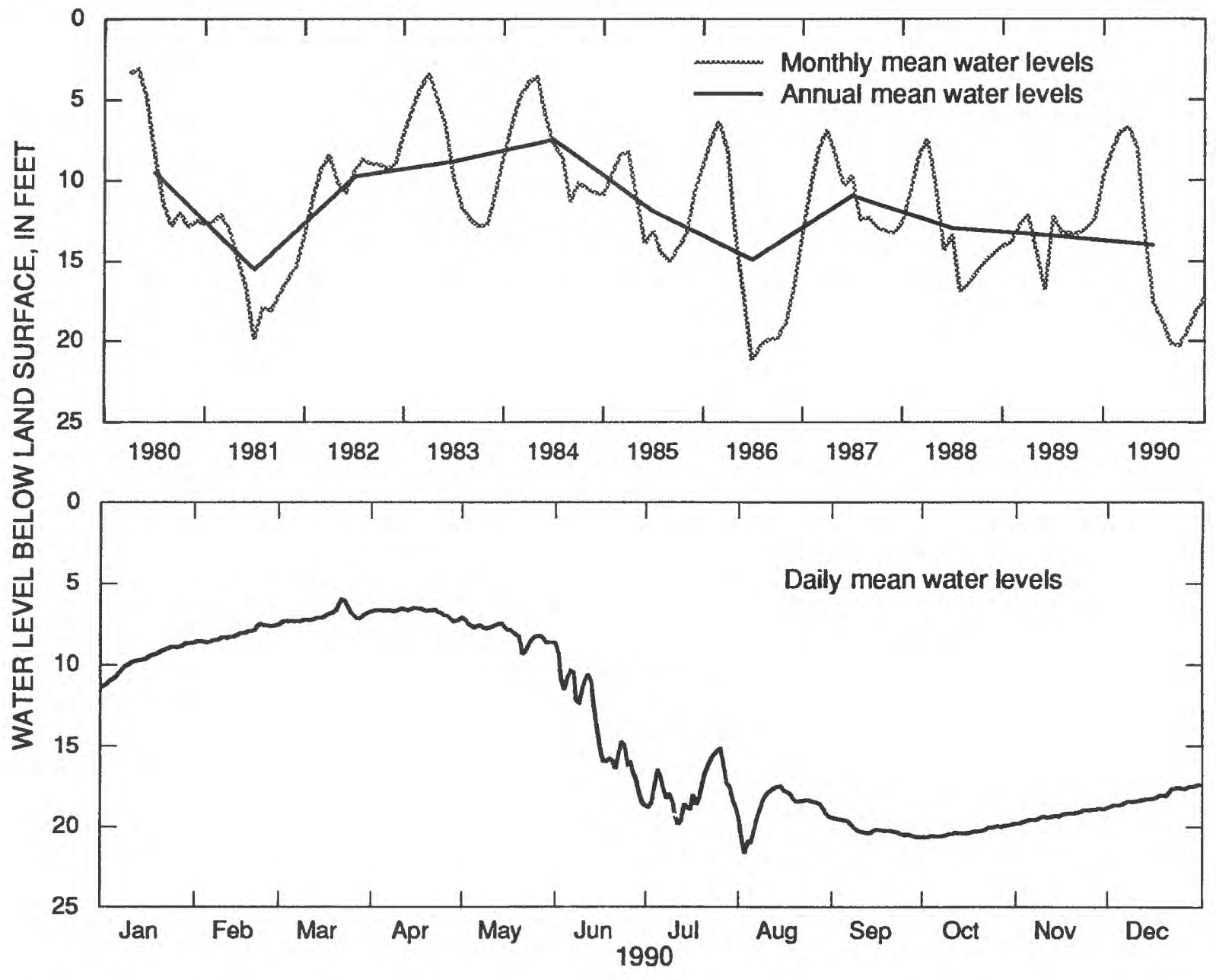

$\begin{array}{rrrrrrrrrrrrr}1990 & \text { JAN } & \text { FEB } & \text { MAR } & \text { APR } & \text { MAY } & \text { JUN } & \text { JUL } & \text { AUG } & \text { SEP } & \text { OCT } & \text { NOV } & \text { DEC } \\ \text { MEAN } & 9.70 & 8.12 & 6.99 & 6.73 & 8.01 & 13.66 & 17.68 & 18.76 & 20.16 & 20.30 & 19.27 & 18.09 \\ \text { LOW } & 11.29 & 8.63 & 7.38 & 7.35 & 9.35 & 18.53 & 19.82 & 21.66 & 20.65 & 20.63 & 19.76 & 18.74 \\ \text { HIGH } & 8.65 & 7.51 & 5.96 & 6.49 & 7.22 & 9.32 & 15.14 & 17.49 & 19.46 & 19.83 & 18.86 & 17.38 \\ \text { CAL YR } & 1990 & & \text { MEAN } & 13.99 & & \text { HIGH } & 5.96 & & \text { LOW } & 21.66 & & \end{array}$

Figure 75.--Water level in observation well 13M005, Worth County. 
315731083542302 Local number, 14P015.

LOCATION.-Lat 31 '57'31", long 83'54'23", Hydrologic Unit 03130006, in the Georgia Veterans Memorial State Park, $500 \mathrm{ft}$ east of park maintenance facility, about 7.5 mi west of Cordele on U.S. Highway 280.

Owner: Georgia Geologic Survey, Veterans Memorial State Park test well 2.

AQUIFER.- Claiborne.

WELL CHARACTERISTICS.--Drilled observation well, diameter 6 in., depth $340 \mathrm{ft}$, cased to $240 \mathrm{ft}$, screen to $340 \mathrm{ft}$.

DATUM.-Altitude of land-surface datum is $252 \mathrm{ft}$.

Measuring point: Top of recorder shelf, $3.0 \mathrm{ft}$ above land-surface datum.

REMARKS.-Aquifer test conducted on April 22, 1982. Well Pumped and sampled by Georgia Geologic Survey, March 22, 1989.

Water levels for periods of missing record, September 3-25, were estimated.

PERIOD OF RECORD.--August 30, 1984, to current year.

EXTREMES FOR PERIOD OF RECORD.--Highest water level, $12.97 \mathrm{ft}$ below land-surface datum, March 9, 1987; lowest, $42.09 \mathrm{ft}$ below land-surface datum, September 2, 1990.

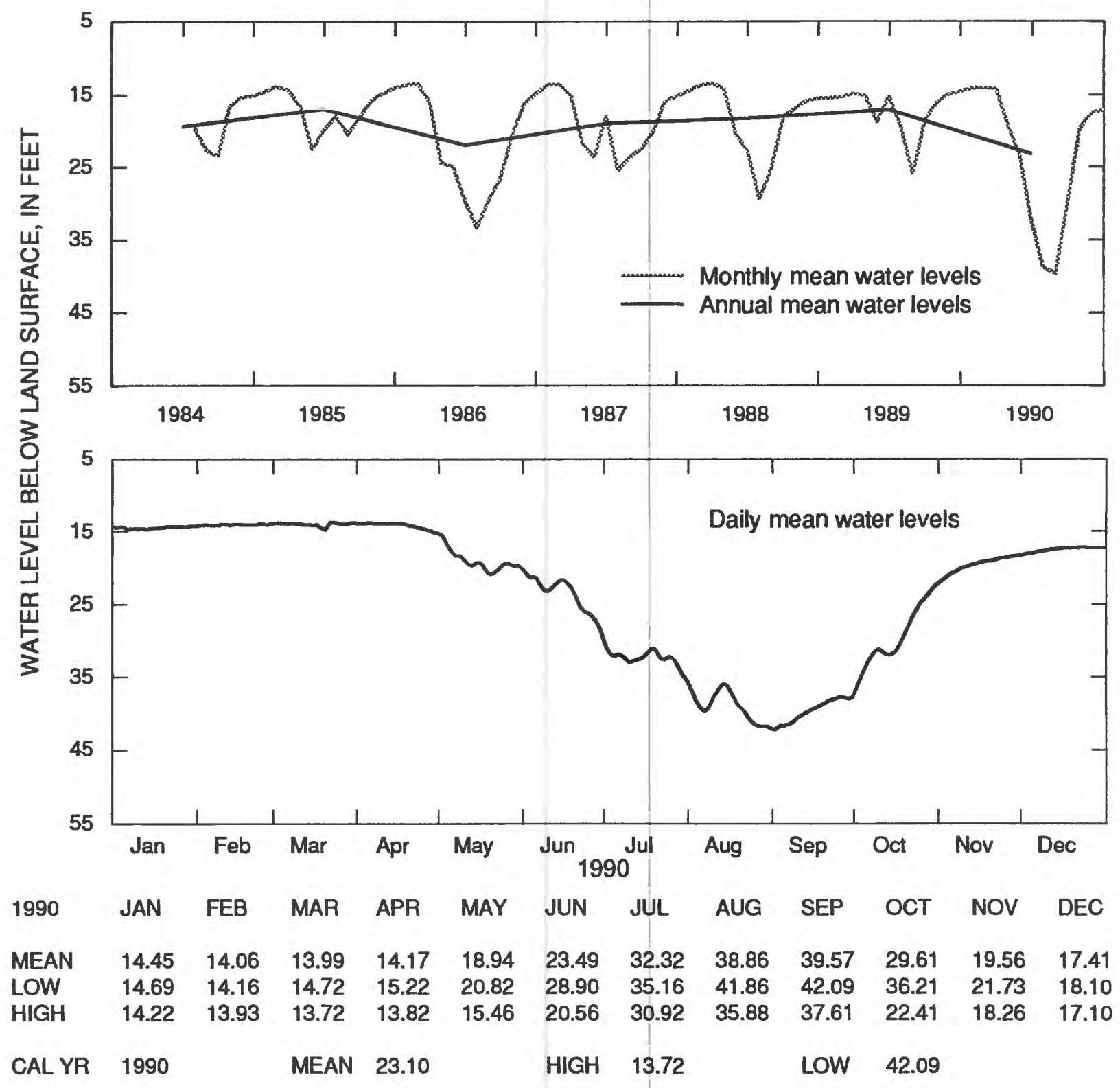

Figure 76.-Water level in observation well 14P015, Crisp County. 


\section{Clayton Aquifer}

The water level in the Clayton aquifer is monitored in 12 wells, 8 of which are summarized in this report (fig. 77). Water levels in wells tapping the aquifer are affected primarily by seasonal variations in local and regional pumping. During 1985, the aquifer supplied more than $33 \mathrm{Mgal} / \mathrm{d}$, primarily for agricultural use (Pierce and Kundell, 1990, p. 219).

During October 1990, water-level measurements from 79 wells tapping the Clayton aquifer were used to construct a water-level-surface map (Peck and Allen, 1991) (fig. 77). A cone of depression has developed at Albany as a result of pumping in the area. The configuration of the water-level surface showed little change from that of 1989 (Peck and others, 1990, fig. 75). However, the areal extent of the cone of depression expanded to the west into Calhoun County; possibly as a result of an increase in pumping in that area.

The annual mean water levels in wells 06K009 (fig. 78), $07 \mathrm{~N} 001$ (fig. 79), $09 \mathrm{M} 007$ (fig. 80), $09 \mathrm{~N} 001$ (fig. 81), $11 \mathrm{~L} 002$ (fig.82), and 13L002 (fig. 83) were from about 1.0 to $11.4 \mathrm{ft}$ lower in 1990 than in 1989. These water-level declines resulted from below-normal precipitation and increased pumping during most of 1990 (see precipitation graph for Albany, fig. 5). In wells 11L002 (fig.82) and 13L002 (fig. 83), the declines reversed an upward trend that began in 1986. Long-term trends are not evident in wells $06 \mathrm{~K} 009$ (fig. 78), 07 N001 (fig. 79), $09 \mathrm{M} 007$ (fig. 80), and 09N001 (fig. 81). The annual mean water levels in wells 11K005 (fig. 84) and 14P014 (fig. 85 ) were about the same and about $0.8 \mathrm{ft}$ higher than in 1989, respectively. The water-level rise in well $14 \mathrm{P} 014$ (fig. 85) continued an upward trend that began in 1987. In well 11K005 (fig. 84), a slight water-level rise reversed a downward trend that has been observed since monitoring began in 1979. Although the annual mean water level was slightly higher in 1990, a record-low daily mean water level was recorded in well 11K005 (fig. 84) in December that was about $1.6 \mathrm{ft}$ lower than the previous record low. 


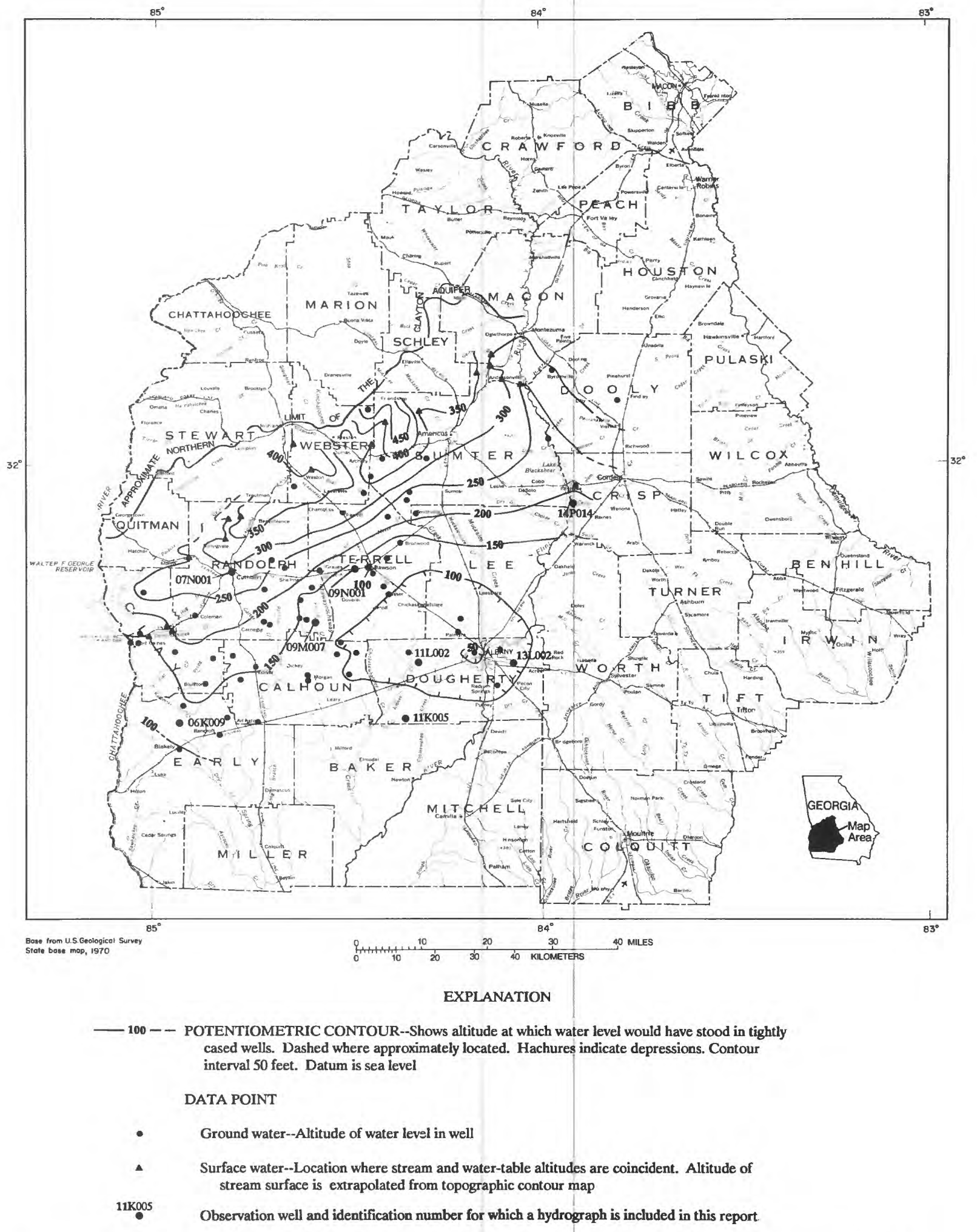

Figure 77.--Water level and locations of observation wells completed in the Clayton aquifer, November 1990. From Peck and Allen (1991). 
312827084551501 Local number, 06K009.

LOCATION.-Lat $31^{\circ} 28^{\prime \prime} 24^{\prime \prime}$, long $84^{\circ} 55^{\prime} 12^{\prime \prime}$, Hydrologic Unit 03130004 , westernmost of two recorder wells, 300 yds north of the pool at Kolomoki Mounds State Park, 4.2 mi north of the city limits of Blakely, on Kolomoki Road.

Owner: Georgia Geologic Survey, Kolomoki Mounds State Park test well 1.

AQUIFER.--Clayton.

WELL CHARACTERISTICS.--Drilled observation well, diameter 6 in., depth $612 \mathrm{ft}$, cased to $491 \mathrm{ft}$, open hole.

DATUM.--Altitude of land-surface datum is $310 \mathrm{ft}$.

Measuring point: Top of recorder shelf, $3.27 \mathrm{ft}$ above land-surface datum.

REMARK.--Borehole geophysical survey conducted November 20, 1979. Aquifer test conducted May 19, 1982. Well pumped and redeveloped August 8, 1989.

PERIOD OF RECORD.--August 31, 1984, to current year.

EXTREMES FOR PERIOD OF RECORD.--Highest water level, $146.62 \mathrm{ft}$ below land-surface datum, April 3, 1986; lowest, $171.38 \mathrm{ft}$ below land-surface datum, August 22, 1986.

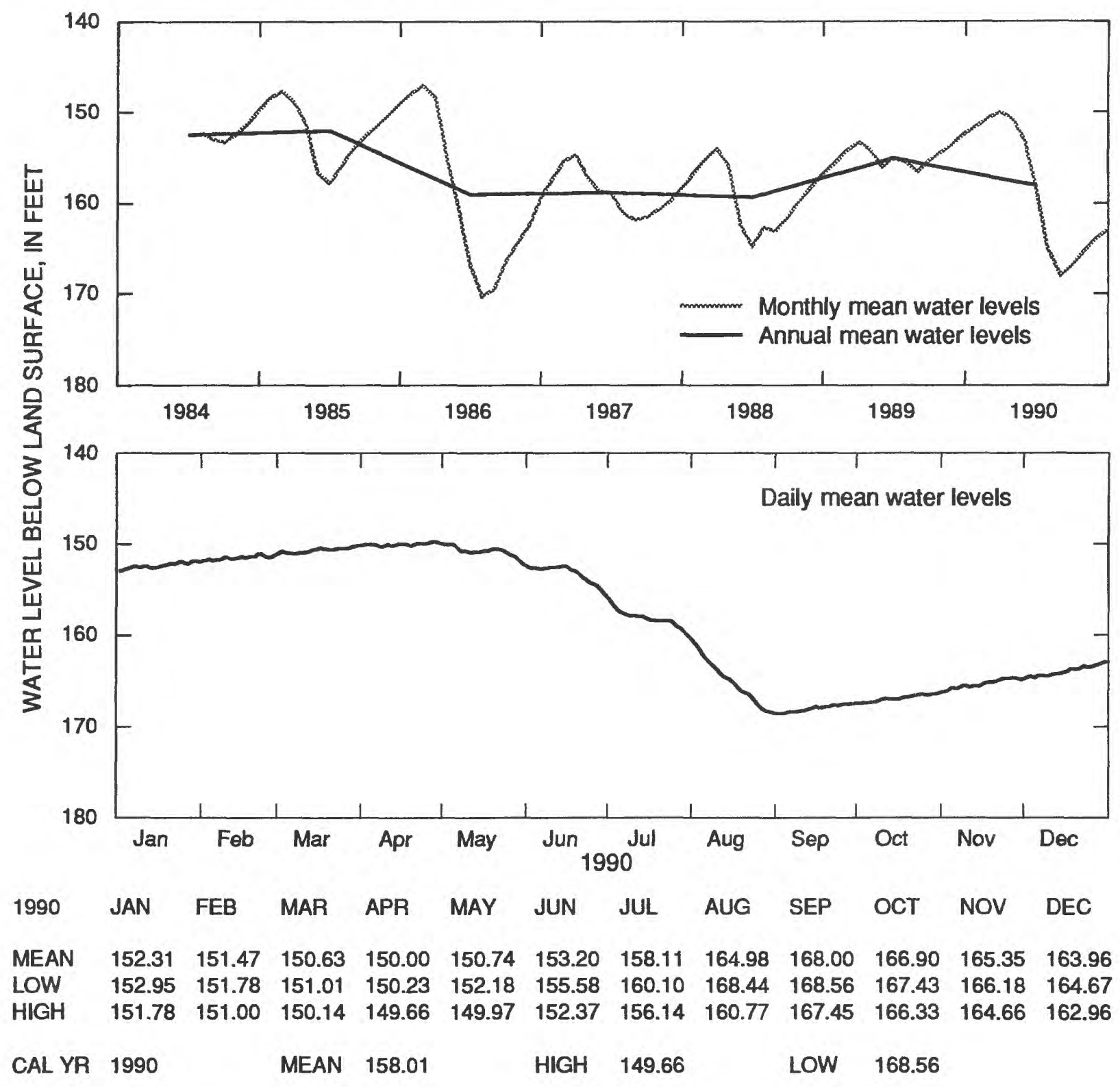

Figure 78.--Water level in observation well 06K009, Early County. 
314602084473701 Local number, 07N001.

LOCATION.--Lat $31^{\circ} 46^{\circ} 09^{\prime \prime}$, long 84 $47^{\prime} 43^{\prime \prime}$, Hydrologic Unit 03110204, south of intersection of College and Andrew Streets, $200 \mathrm{ft}$ southwest of Cuthbert city supply well, near electric substation.

Owner: City of Cuthbert.

AQUIFER.--Clayton.

WELL CHARACTERISTICS.--Drilled unused municipal well, diameter 8 in., depth $372 \mathrm{ft}$, casing depth unknown.

DATUM.--Altitude of land-surface datum is $460 \mathrm{ft}$.

Measuring point: Top of recorder shelf, $3.30 \mathrm{ft}$ above land-surface datum.

REMARKS.-Well pumped and redeveloped August 8, 1989. Well near city wells.

PERIOD OF RECORD.--January 1965 to current year.

EXTREMES FOR PERIOD OF RECORD.--Highest water level, $132.0 \mathrm{ft}$ below land-surface datum, December 10, 1967; lowest, $162.08 \mathrm{ft}$ below land-surface datum, August 4, 1986.

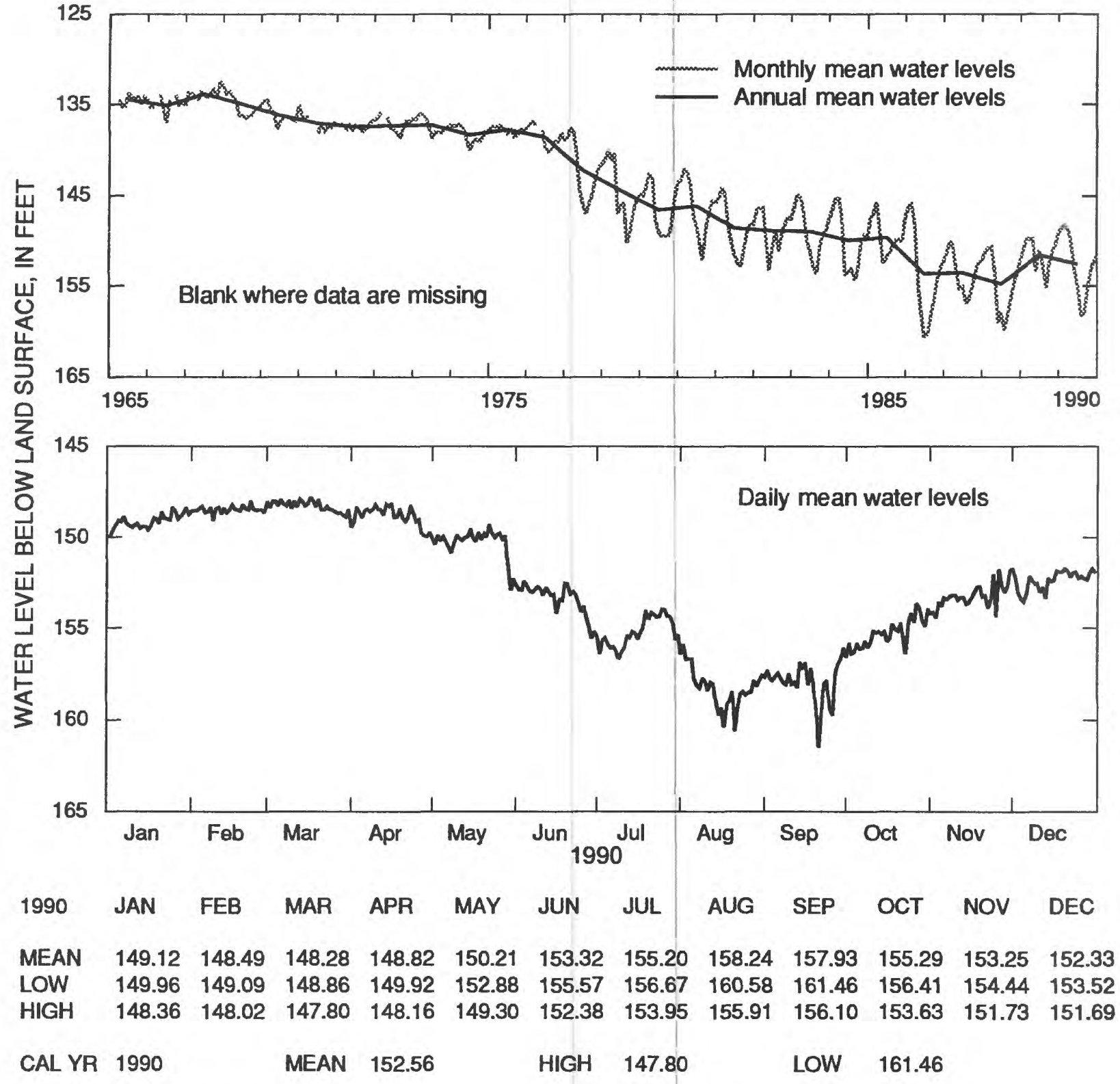

Figure 79.--Water level in observation well 07N001, Randolph County. 
313953084361202 Local number, $09 \mathrm{M} 007$.

LOCATION.--Lat 31'39'52", long $84^{\circ} 36^{\prime} 12^{\prime \prime}$, Hydrologic Unit 03130009, westernmost of two observation wells, $0.2 \mathrm{mi}$ east of Georgia Highway 41, 7.2 mi south of the intersection of U.S. Highway 82 and Georgia Highway 41 in Shellman.

Owner: C.T. Martin test well 2.

AQUIFER.--Clayton.

WELL CHARACTERISTICS.--Drilled observation well, diameter 6 in., depth $430 \mathrm{ft}$, cased to $356 \mathrm{ft}$, open hole.

DATUM.--Altitude of land-surface datum is $322 \mathrm{ft}$.

Measuring point: Top of recorder shelf, $3.25 \mathrm{ft}$ above land-surface datum.

REMARKS.--Borehole geophysical survey conducted April 15, 1980. Aquifer test conducted April 4, 1982. Well pumped and redeveloped August 8, 1989. Water levels for periods fo missing record, July 3-16 and August 3-20, were estimated. PERIOD OF RECORD.--September 14, 1984, to current year.

EXTREMES FOR PERIOD OF RECORD.--Highest water level, $126.55 \mathrm{ft}$ below land-surface datum, March 27, 1986; lowest, $212.90 \mathrm{ft}$ below land-surface datum, July $23,1986$.

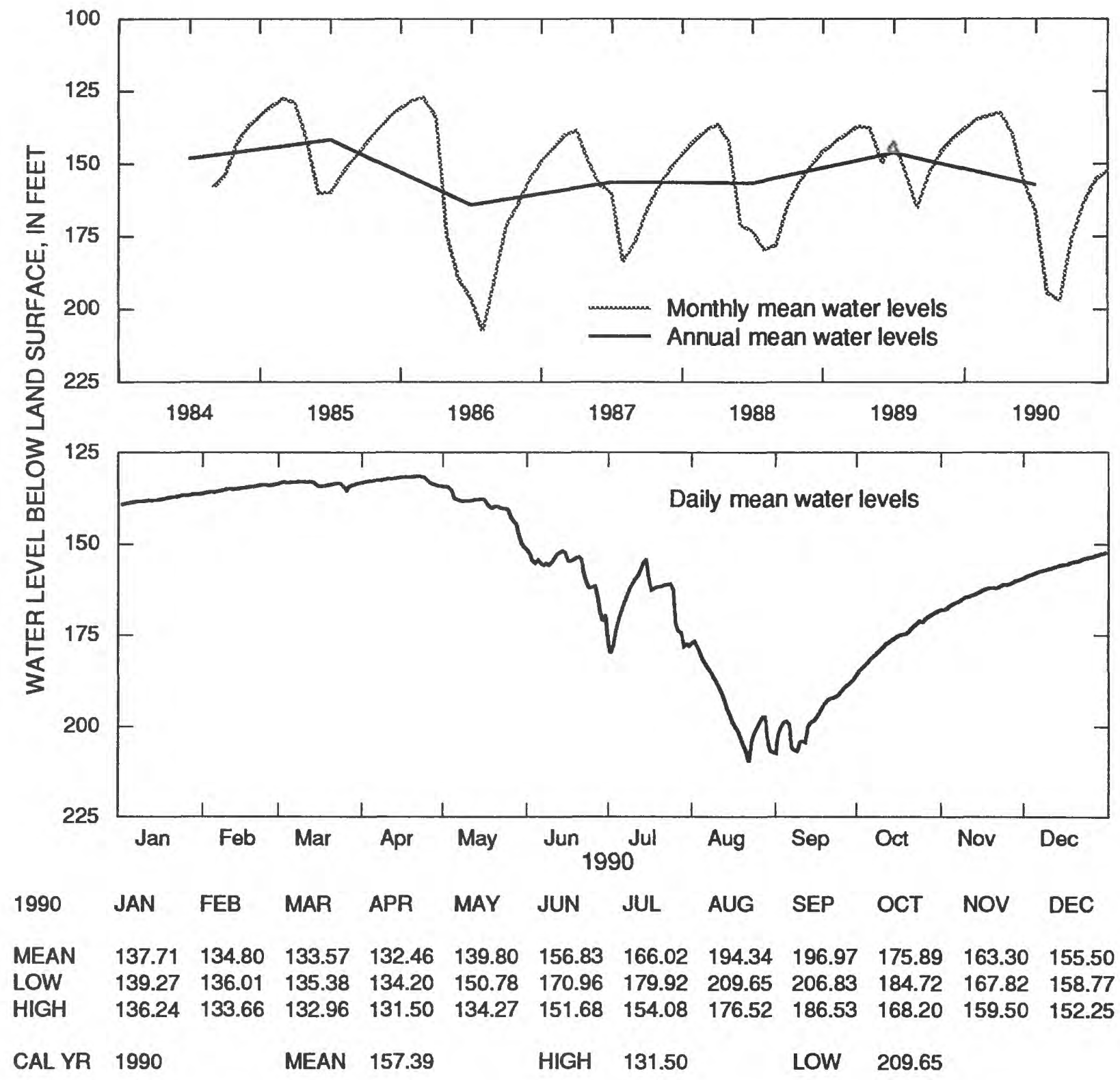

Figure 80.--Water level in observation well 09M007, Randolph County. 
314611084310301 Local number, 09N001.

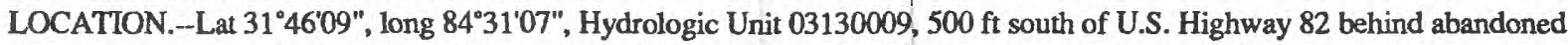
school foundations in block house, $1.0 \mathrm{mi}$ west of intersection of U.S. Highway 82 and Georgia Highway 45.

Owner: Bill Newman

AQUTFER.-Clayton.

WELL CHARACTERISTICS.--Drilled unused supply well, diameter 6 in., depth $433 \mathrm{ft}$, cased to $333 \mathrm{ft}$, open hole.

DATUM.-Altitude of land-surface datum is $348 \mathrm{ft}$.

Measuring point: Top of 6 in. well casing, $0.55 \mathrm{ft}$ below land-surface datum.

REMARKS.--Borehole geophysical survey conducted July 31, 1953. Well pumped and redeveloped August 9, 1989. Water levels for periods of missing record, August 1-20, and September 1-23, yere estimated.

PERIOD OF RECORD.--January 10,1982, to current year.

EXTREMES FOR PERIOD OF RECORD.--Highest water level, $144.06 \mathrm{ft}$ below land-surface datum, May 16, 1984; lowest, $241.61 \mathrm{ft}$ below land-surface datum, July 21, 1986.

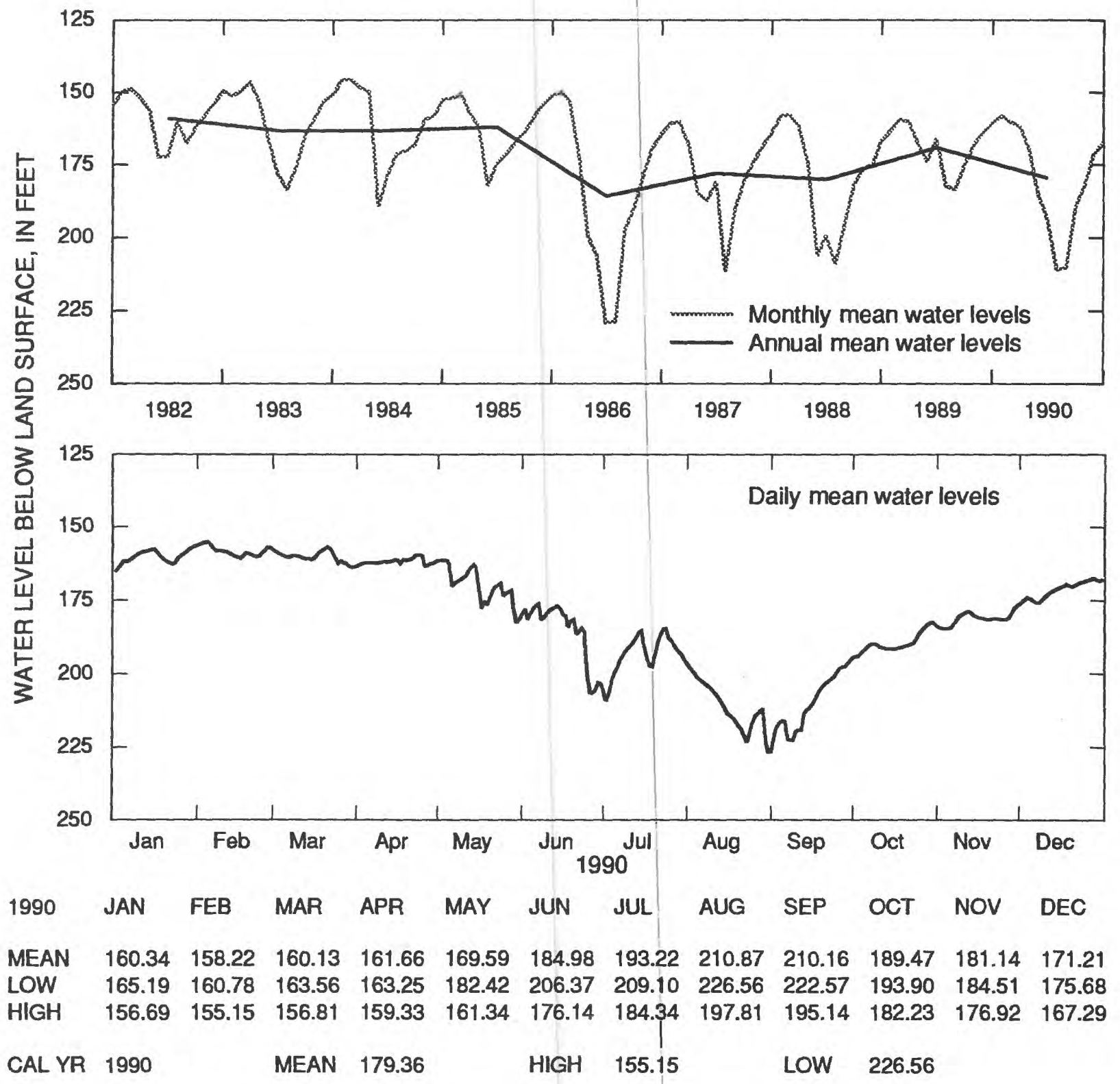

Figure 81.--Water level in observation well 09N001, Terrell County. 
313532084203501 Local number, $11 \mathrm{LO02}$.

LOCATION.--Lat $31^{\circ} 35^{\prime} 32^{\prime \prime}$, long $84^{\circ} 20^{\circ} 35^{\prime \prime}$, Hydrologic Unit 03130008, Tallahassee Plantation, 1.3 mi north of

Georgia Highway 234, 10.4 mi west of Albany.

Owner: Georgia Geologic Survey, Albany Nursery.

AQUIFER.--Clayton.

WELL CHARACTERISTICS.--Drilled observation well, diameter 3 in., depth $656 \mathrm{ft}$, cased to $542 \mathrm{ft}$, open hole.

DATUM.--Altitude of land-surface datum is $222 \mathrm{ft}$.

Measuring point: Top of recorder shelf, $3.02 \mathrm{ft}$ above land-surface datum.

REMARKS.--Well pumped and redeveloped August 14, 1988. Borehole geophysical survey conducted June 3, 1975. Water levels of the period of missing record, May 5-28, were estimated.

PERIOD OF RECORD.--September 1973 to current year.

EXTREMES FOR PERIOD OF RECORD.--Highest water level, $58.90 \mathrm{ft}$ below land-surface datum, April 29, 1975; lowest, $152.61 \mathrm{ft}$ below land-surface datum, August 23, 1986.

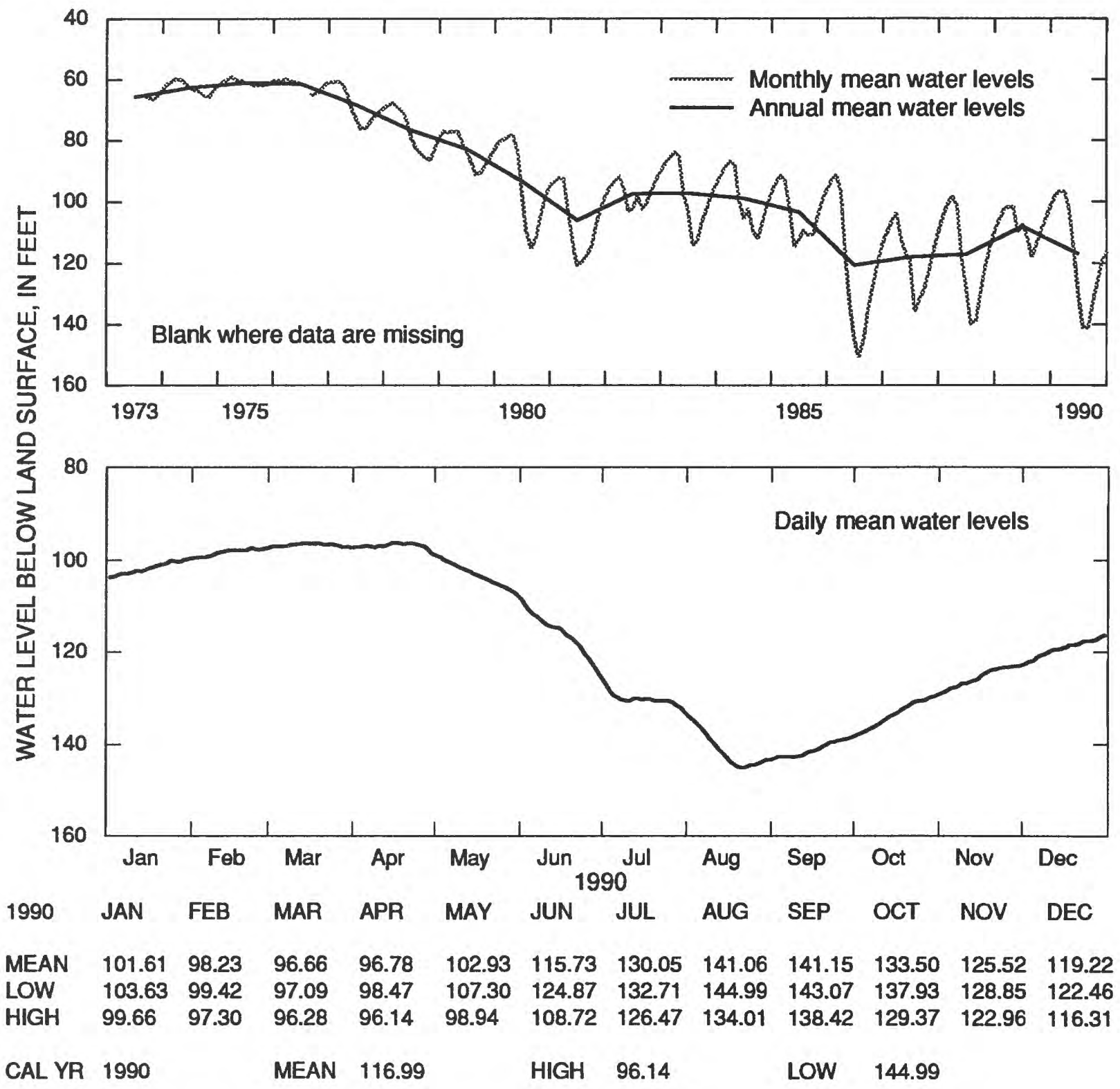

Figure 82.--Water level in observation well 11L002, Dougherty County. 
313554084062501 Local number, $13 \mathrm{~L} 002$.

LOCATION.--Lat $31^{\circ} 35^{\circ} 51^{\prime \prime}$, long $84^{\circ} 06^{\prime} 24^{\prime \prime}$, Hydrologic Unit $03130008,50 \mathrm{ft}$ west of Albany city supply well house,

$75 \mathrm{ft}$ east of church located at the comer of Malone and Gardner Avenue.

Owner: Albany Water, Gas, and Light Commission, Turner City 2.

AQUIFER.--Clayton.

WELL CHARACTERISTICS.--Drilled unused supply well, diameter $12 \mathrm{in}$., depth $760 \mathrm{ft}$, cased to $713 \mathrm{ft}$, open hole.

DATUM.--Altitude of land-surface datum is $212.84 \mathrm{ft}$.

Measuring point: Top of recorder shelf, $3.2 \mathrm{ft}$ above land-surface datum.

REMARKS.--Well pumped and sounded to a depth of $760 \mathrm{ft}$. June 21 , 1978; water-quality sample collected at conclusion

of pumping. Borehole geophysical survey conducted March 17, 1977. Water levels for periods of missing record,

June 16-20 and December 22-31, were estimated.

PERIOD OF RECORD.--December 1957 to December 1959. January 1962 to current year.

EXTREMES FOR PERIOD OF RECORD.--Highest water level, $38.19 \mathrm{ft}$ below land-surface datum, April 1, 1959; lowest, $160.88 \mathrm{ft}$ below land-surface datum. Julv 26. 1986.

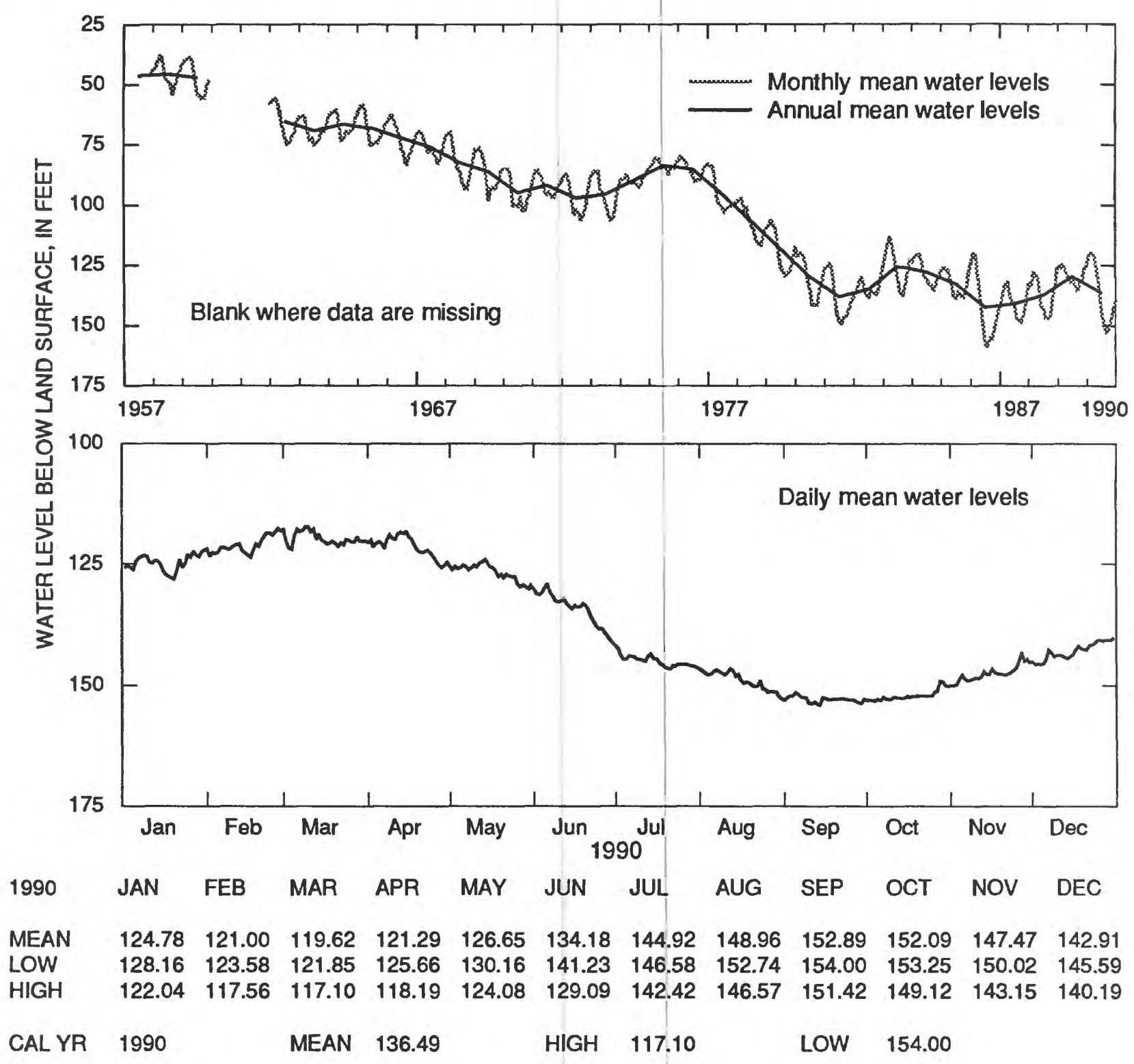

Figure 83.--Water level in observation well 13L002, Dougherty County. 
312654084210103 Local number, 11K005.

LOCATION.-Lat $31^{\circ} 26^{\prime} 54^{\prime \prime}$, long $84^{\circ} 21^{\prime} 01^{\prime \prime}$, Hydrologic Unit 03130008, easternmost of two recorder wells, $50 \mathrm{ft}$ east of logging road, $0.65 \mathrm{mi}$ west and 0.65 south of main gate into the St. Joe Paper Company woodland on Tarva Road, $3.6 \mathrm{mi}$ south of Georgia Highway 62 .

Owner: U.S. Geological Survey, test well 12.

AQUIFER.--Clayton.

WELL CHARACTERISTICS.--Drilled observation well, diameter 6 in., depth $690 \mathrm{ft}$, cased to $630 \mathrm{ft}$, open hole.

DATUM.--Altitude of land-surface datum is $183 \mathrm{ft}$.

Measuring point: Top of recorder shelf, $3.0 \mathrm{ft}$ above land-surface datum.

REMARKS.--Borehole geophysical survey conducted March 14, 1979.

PERIOD OF RECORD.--May 16, 1979, to current year.

EXTREMES FOR PERIOD OF RECORD.--Highest water level, $23.03 \mathrm{ft}$ below land-surface datum, May 24, 1979; lowest, $58.72 \mathrm{ft}$ below land-surface datum, December 31, 1990.

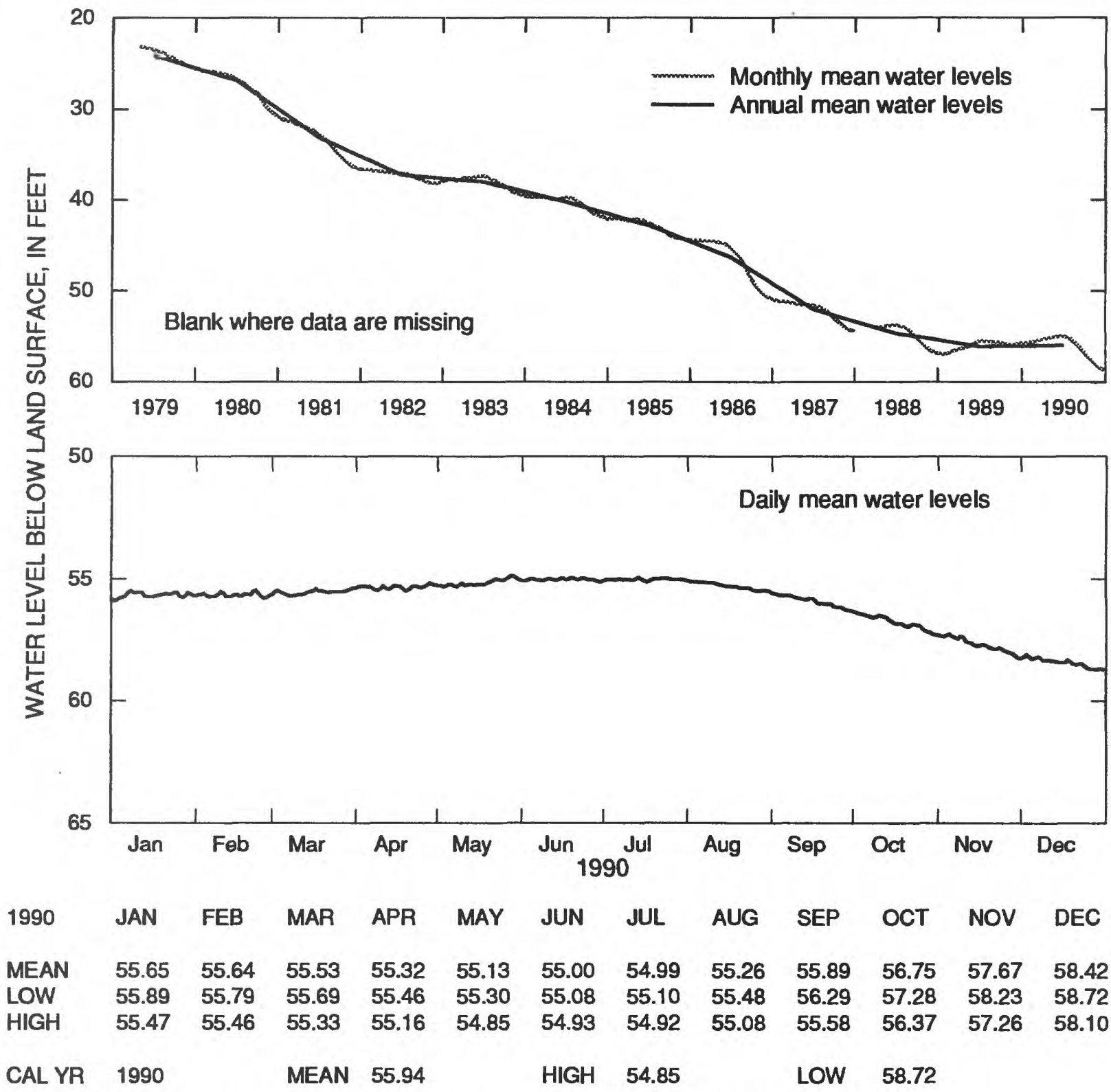

Figure 84.--Water level in observation well 11K005, Dougherty County. 
315731083542301 Local number, $14 \mathrm{P} 014$.

LOCATION.--Lat $31^{\circ} 57^{\prime} 31^{\prime \prime}$, long 83'54'23", Hydrologic Unit 03130006, in the Georgia Veterans Memorial State Park,

$500 \mathrm{ft}$ east of park maintenance facility, about $7.5 \mathrm{mi}$ west of Cordele on U.S. Highway 280.

Owner: Georgia Geologic Survey, Veterans Memorial Park test well 1.

AQUIFER.--Clayton.

WELL CHARACTERISTICS.--Drilled observation well, diameter 6 in., depth $550 \mathrm{ft}$, cased to $500 \mathrm{ft}$, open hole.

DATUM.--Altitude of land-surface datum is $252 \mathrm{ft}$.

Measuring point: Top of recorder shelf, $3.1 \mathrm{ft}$ above land-surface datum.

REMARKS.--Well pumped May 20, 1982. Borehole geophysical survey conducted February 22, 1982.

PERIOD OF RECORD.--September 1984 to current year.

EXTREMES FOR PERIOD OF RECORD.--Highest water level, $37.16 \mathrm{ft}$ below land-surface datum, September 2, 1984; lowest, $49.26 \mathrm{ft}$ below land-surface datum, November 29, 1988.

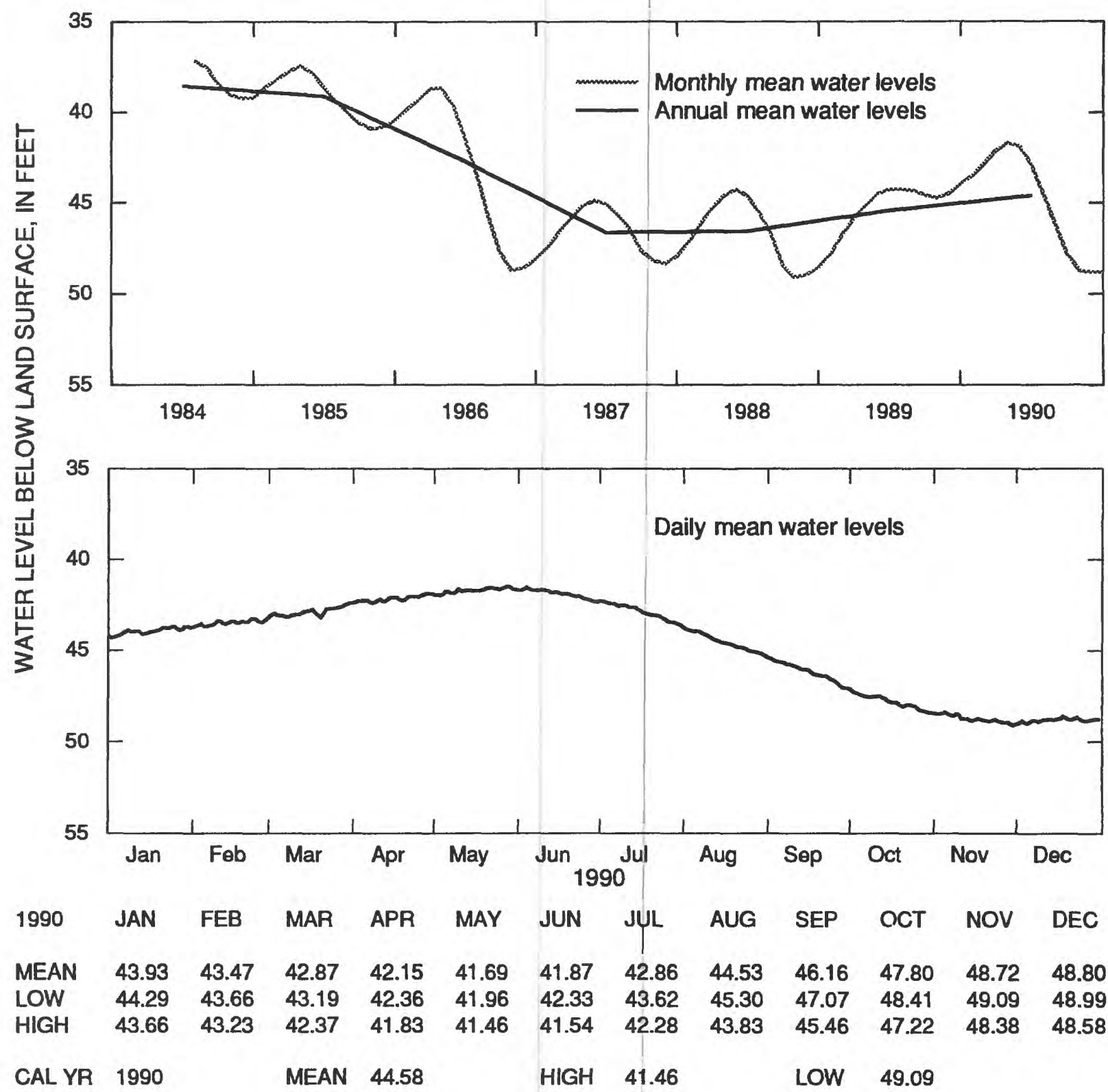

Figure 85.--Water level in observation well 14P014, Crisp County. 


\section{Cretaceous Aquifers and Aquifer Systems}

Water levels in Cretaceous aquifers and aquifer systems are monitored in nine wells, all of which are summarized in this report (fig. 86). The Cretaceous aquifers and aquifer systems include the Providence aquifer in southwestern Georgia and the Dublin aquifer system, the Midville aquifer system, and the DublinMidville aquifer system in the northeastern part of the Coastal Plain. Water levels in these aquifers and aquifer systems are influenced by variations in precipitation and pumping. During 1985, the Cretaceous aquifers and aquifer systems supplied more than $147 \mathrm{Mgal} / \mathrm{d}$, primarily for municipal and industrial use (Pierce and Kundell, 1990, p. 219).

In Chattahoochee County near Columbus, the annual mean water level in well 065001 (fig. 87), which taps an unnamed sand aquifer in the Late Cretaceous Blufftown, Eutaw, and Tuscaloosa Formations, was about $1.4 \mathrm{ft}$ lower in 1990 than in 1989. This water-level decline continues a downward water-level trend that began in this well in 1965 (fig 87). A record-low daily mean water level was recorded in this well in December that was about $2.4 \mathrm{ft}$ lower than the previous record low. 


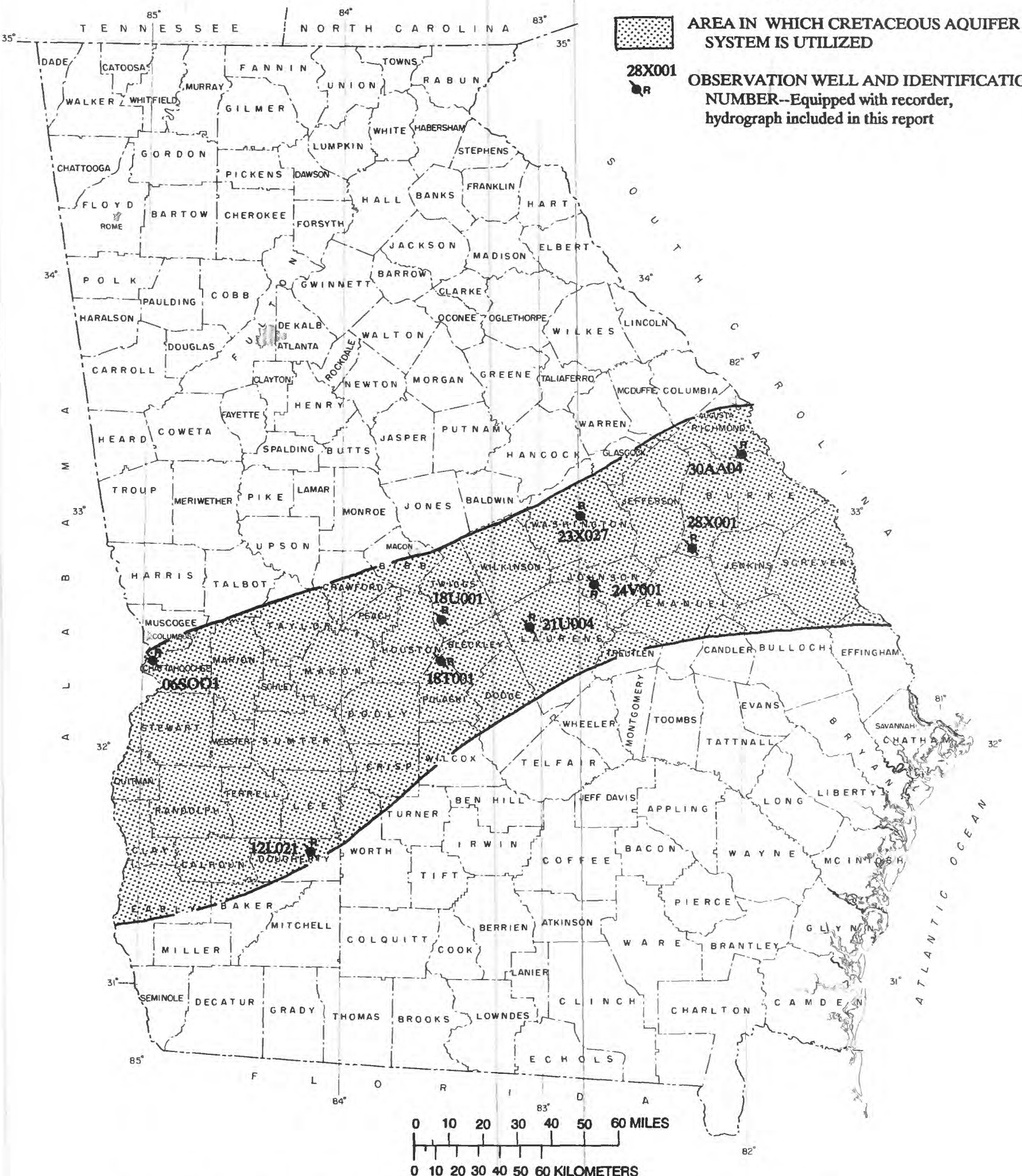

Figure 86.--Locations of observation wells completed in Cretaceous aquifers and aquifer systems. 
LOCATION.-Lat 32²0'31", long 84 59'10", Hydrologic Unit 03130003, in "Motor Pool" across road from Lawson

Airfield main building.

Owner: U.S. Army, Fort Benning.

AQUIFER.-- Cretaceous (Blufftown, Eutaw, and Tuscaloosa Formations).

WELL CHARACTERISTICS.--Drilled unused supply well, diameter 12 in., depth $568 \mathrm{ft}$, screened intervals $215-220 \mathrm{ft}$, 230-235 ft, $280-290 \mathrm{ft}$, and $540-550 \mathrm{ft}$.

DATUM--Altitude of land-surface datum is $255 \mathrm{ft}$.

Measuring point: Top of recorder shelf, $2.80 \mathrm{ft}$ above land-surface datum.

REMARKS.--Well pumped and redeveloped August 7, 1989. Well pumped and sampled by Georgia Geologic Survey

November 29-30, 1989.

PERIOD OF RECORD.--May 1950 to current year.

EXTREMES FOR PERIOD OF RECORD.-Highest water level, $0.37 \mathrm{ft}$ below land-surface datum, April 10, 1964; lowest,

$33.55 \mathrm{ft}$ below land-surface datum, December 26-27, 1990.

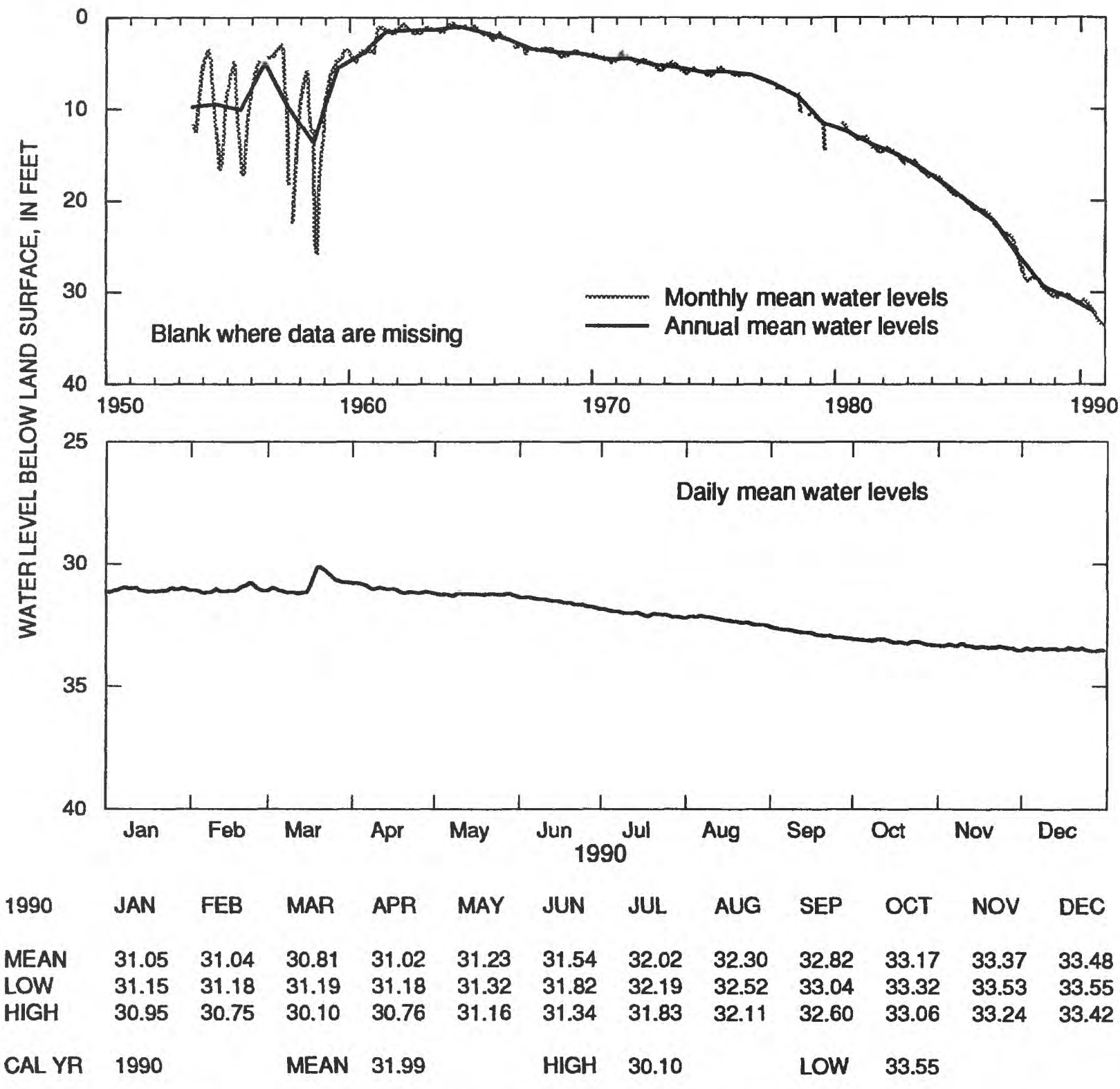

Figure 87.--Water level in observation well 06S001, Chattahoochee County. 


\section{Providence aquifer}

The water level in the Providence aquifer in the Albany area is monitored in one well (fig. 86) and is affected primarily by variations in local pumping. The aquifer supplied about $9 \mathrm{Mgal} / \mathrm{d}$ for municipal, industrial, and agricultural use in southwestern Georgia during 1980 (Clarke and others, 1983). The water-level response to pumping is shown on the hydrograph for well 12L021 at Albany (fig. 88). In 1990, the annual mean water level in this well was about $9.9 \mathrm{ft}$ lower than in 1989. This water-level decline reversed an upward trend that began in 1986. 
313534084103003 Local number, 12 L021.

LOCATION.--Lat $31^{\circ} 35^{\prime} 37^{\prime \prime}$, long $84^{\circ} 10^{\prime} 29^{\prime \prime}$, Hydrologic Unit 03130008, located in park at intersection of Slappey

Drive and Fifth Avenue.

Owner: U.S. Geological Survey, test well 10.

AQUIFER.--Providence

WELL CHARACTERISTICS.--Drilled observation well, diameter 6 in., depth $834 \mathrm{ft}$, cased to $810 \mathrm{ft}$, screen to $830 \mathrm{ft}$.

DATUM.-Altitude of land-surface datum is $198 \mathrm{ft}$.

Measuring point: Top of recorder shelf, $3.0 \mathrm{ft}$ above land-surface datum.

REMARKS.--Borehole geophysical survey conducted October 26, 1978. Well pumped and sampled October 24, 1989.

PERIOD OF RECORD.--December 1978 to current year.

EXTREMES FOR PERIOD OF RECORD.--Highest water level, $101.59 \mathrm{ft}$ below land-surface datum, April 26, 1984; lowest,

$156.36 \mathrm{ft}$ below land-surface datum, July $26,1986$.
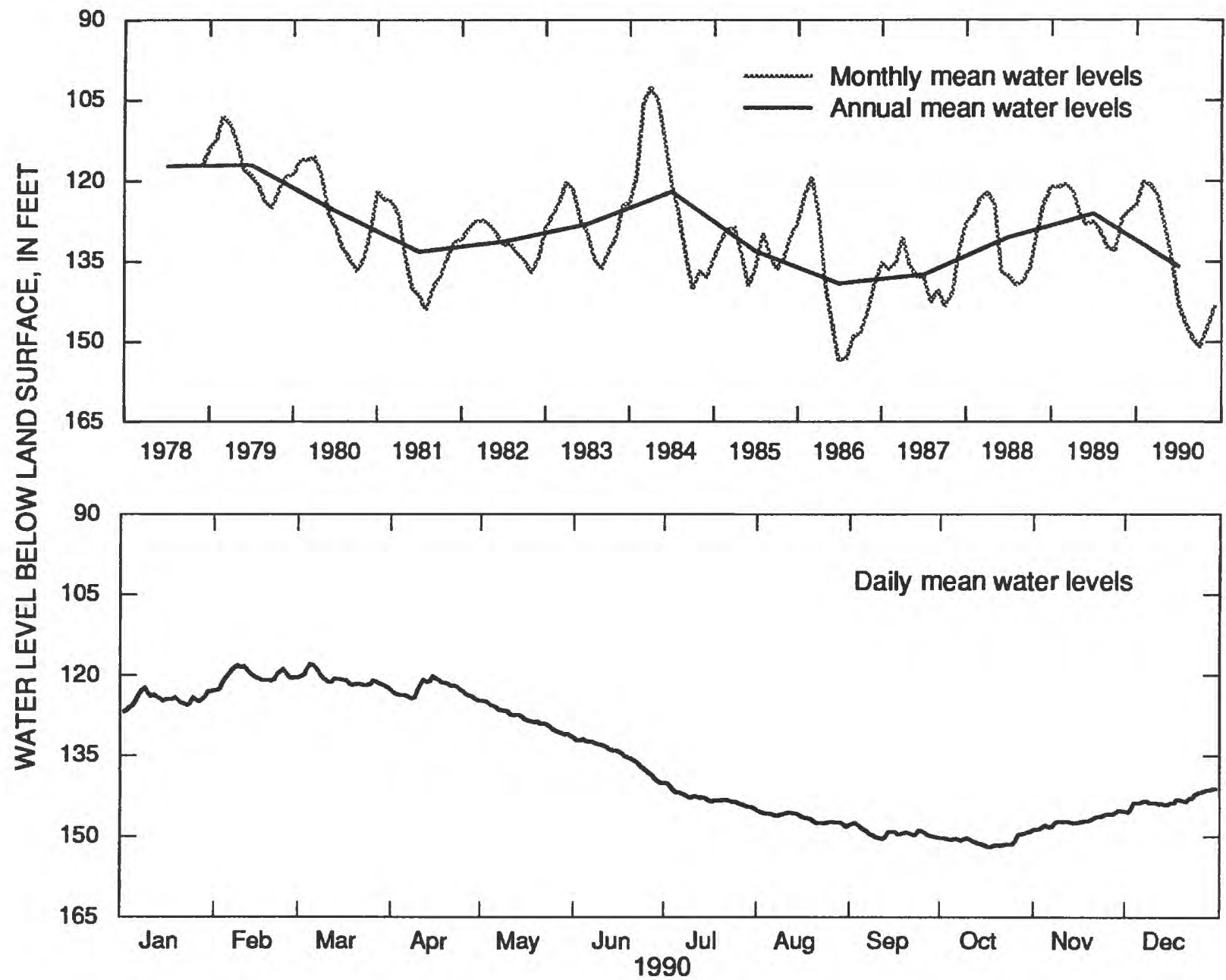

$\begin{array}{lllllllllllll}1990 & \text { JAN } & \text { FEB } & \text { MAR } & \text { APR } & \text { MAY } & \text { JUN } & \text { JUL } & \text { AUG } & \text { SEP } & \text { OCT } & \text { NOV } & \text { DEC } \\ \text { MEAN } & 124.48 & 120.09 & 120.67 & 122.51 & 128.03 & 134.81 & 142.82 & 146.51 & 149.29 & 150.80 & 147.08 & 143.23 \\ \text { LOW } & 126.84 & 122.62 & 122.15 & 124.59 & 131.22 & 140.02 & 144.67 & 148.15 & 150.41 & 151.90 & 148.70 & 145.50 \\ \text { HIGH } & 122.34 & 118.10 & 117.88 & 120.12 & 124.70 & 131.88 & 140.03 & 145.38 & 147.50 & 149.10 & 145.20 & 141.10 \\ \text { CAL YR } & 1990 & & \text { MEAN } & 135.96 & & \text { HIGH } & 117.88 & & \text { LOW } & 151.90 & & \end{array}$

Figure 88.--Water level in observation well 12L021, Dougherty County. 


\section{Dublin aquifer system}

The water level in the Dublin aquifer system is monitored in one well in southern Twiggs County (fig. 86). In this area, water levels in wells tapping the aquifer are affected by precipitation and by pumping in eastern Houston and western Twiggs Counties (Clarke and others, 1985a), where pumpage exceeded $37 \mathrm{Mgal} / \mathrm{d}$ in 1985 (Turlington and others, 1987). The annual mean water level in well $18 \mathrm{U} 001$ (fig. 89) was about $0.2 \mathrm{ft}$ lower in 1990 than in 1989, continuing a downward trend that began in 1987. A record-low daily mean water level was recorded in this well in October that was slightly lower than the previous record low. 
323302083263401 Local number, $18 \mathrm{U} 001$.

LOCATION.--Lat $32^{\circ} 33^{\prime} 02^{\prime \prime}$, long $83^{\circ} 26^{\prime} 34^{\prime \prime}$, Hydrologic Unit $03070104,0.6 \mathrm{mi}$ north of intersection of U.S. Highways 23 and 12 and $\mathrm{Ga}$. Highway $96,100 \mathrm{ft}$ west of highway near Woods Road West.

Owner: Georgia Kraft, U.S. Geological Survey, test well 3.

AQUIFER.--Dublin aquifer system.

WELL CHARACTERISTICS.--Drilled observation well, diameter 6 in., depth $616 \mathrm{ft}$, cased to $586 \mathrm{ft}$, screen to $616 \mathrm{ft}$.

DATUM.--Allitude of land-surface datum is $442 \mathrm{ft}$.

Measuring point: Top of recorder shelf, $2.6 \mathrm{ft}$ above land-surface datum.

REMARKS.--Water-quality analysis June 10, 1975.

PERIOD OF RECORD.--July 1975 to current year.

EXTREMES FOR PERIOD OF RECORD.--Highest water level, $162.0 \mathrm{ft}$ below land-surface datum, April 4, 1977; lowest,

$166.44 \mathrm{ft}$ below land-surface datum, October 3, 1990.
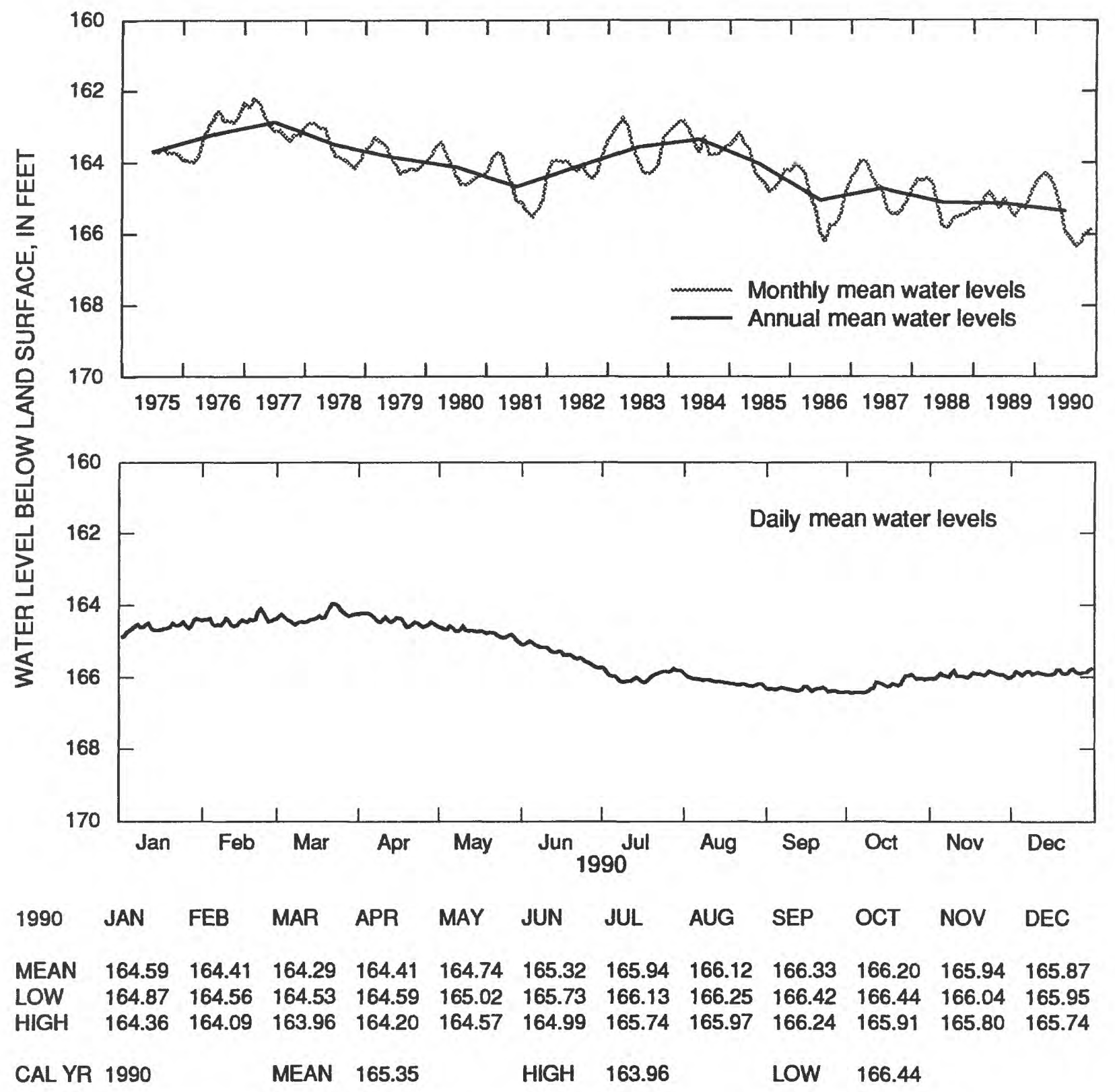

Figure 89.--Water level in observation well 18U001, Twiggs County. 
The water level in the Midville aquifer system is affected primarily by regional pumping (Clarke and others, 1985a) and is monitored in four wells in east-central Georgia, all of which are summarized in this report (fig. 86). In 1990, the annual mean water levels in wells 18T001 (fig. 90), $21 \mathrm{U} 004$ (fig. 91), 24V001 (fig. 92), and 28X001(fig. 93) were from about the same to about $0.7 \mathrm{ft}$ lower than in 1989. These water-level declines continued downward trends that began in 1984 in well 18T001 (fig. 90), and that have been observed since monitoring began in 1982 in well 21 U004 (fig. 91) and in 1980 in wells 24V001 (fig. 92) and 28X001 (fig. 93). Record-low daily mean water levels were recorded in the four wells during October to November that were from about 0.2 to $1.6 \mathrm{ft}$ lower than previous record lows. The sharp rise in water levels in October that can be seen in the hydrographs for wells 21U004, 24V001, and 23X001 was possibly caused by an increase in pressure within the aquifer system that resulted from heavy rainfall and flooding in October (J.S. Clarke, U.S. Geological Survey, oral commun., 1991). (See precipitation graph for Augusta, fig. 7.) 
322245083290101 Local number, $18 \mathrm{T001}$.

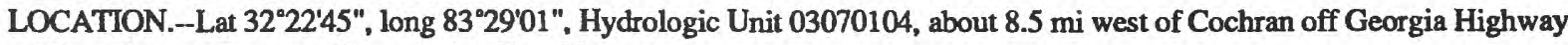
126, at Georgia Forestry Commission Tree Nursery.

Owner: U.S. Geological Survey, Arrowhead test well 1.

AQUIFER.--Midville aquifer system.

WELL CHARACTERISTICS.--Drilled observation well, diameter 6 in., depth 1,555 ft, cased to $970 \mathrm{ft}$, screened intervals, 970-980 ft, 1,110-1,130 ft, and 1,270-1,280 ft.

DATUM.--Altitude of land-surface datum is $334 \mathrm{ft}$.

Measuring point: Top of recorder shelf, $3.0 \mathrm{ft}$ above land-surface datum.

REMARKS.--Borehole geophysical survey conducted January 28 and April 15, 1981. Water-quality analysis May 12, 1981.

PERIOD OF RECORD.--June 1981 to current year.

EXTREMES FOR PERIOD OF RECORD.--Highest water level, $55.48 \mathrm{ft}$ below land-surface datum, April 12, 1983; lowest, $59.52 \mathrm{ft}$ below land-surface datum, October 7-8, 1990.

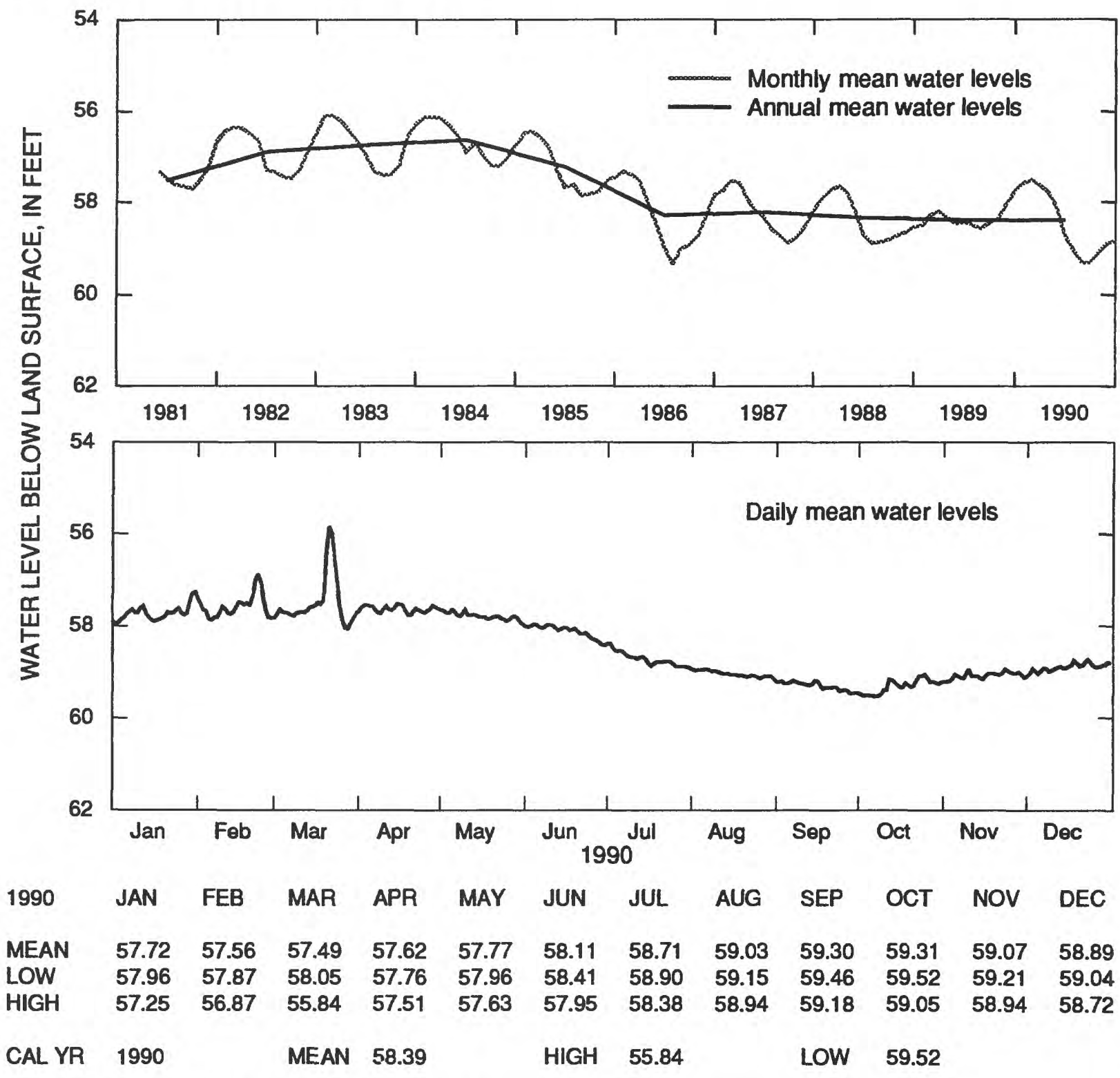

Figure 90.--Water level in observation well 18T001, Pulaski County. 
323030083030003 Local number, 21 U004.

LOCATION.-Lat $32^{\circ} 30^{\prime} 27^{\prime \prime}$, long $83^{\circ} 02^{\prime} 44^{\prime \prime}$, Hydrologic Unit 03070102 , at rest area No. 87 on Interstate 16 east between mile posts 43 and 44 .

Owner: U.S. Geological Survey, Laurens 3.

AQUIFER.--Midville aquifer system.

WELL CHARACTERISTICS.--Drilled observation well, diameter 6 in., depth $1,685 \mathrm{ft}$, cased to $1,060 \mathrm{ft}$, screened intervals, $1,060-1,080 \mathrm{ft}$, and 1,220-1,240 ft.

DATUM.--Altitude of land-surface datum is $282 \mathrm{ft}$.

Measuring point: Top of recorder shelf, $3.0 \mathrm{ft}$ above land-surface datum.

REMARKS.--Borehole geophysical survey conducted December 4, 1981. Water-quality analysis January 28, 1982.

PERIOD OF RECORD.--February 1982 to current year.

EXTREMES FOR PERIOD OF RECORD.--Highest water level, $35.17 \mathrm{ft}$ below land-surface datum, April 3, 1983; lowest, $39.63 \mathrm{ft}$ below land-surface datum, October 8, 1990.

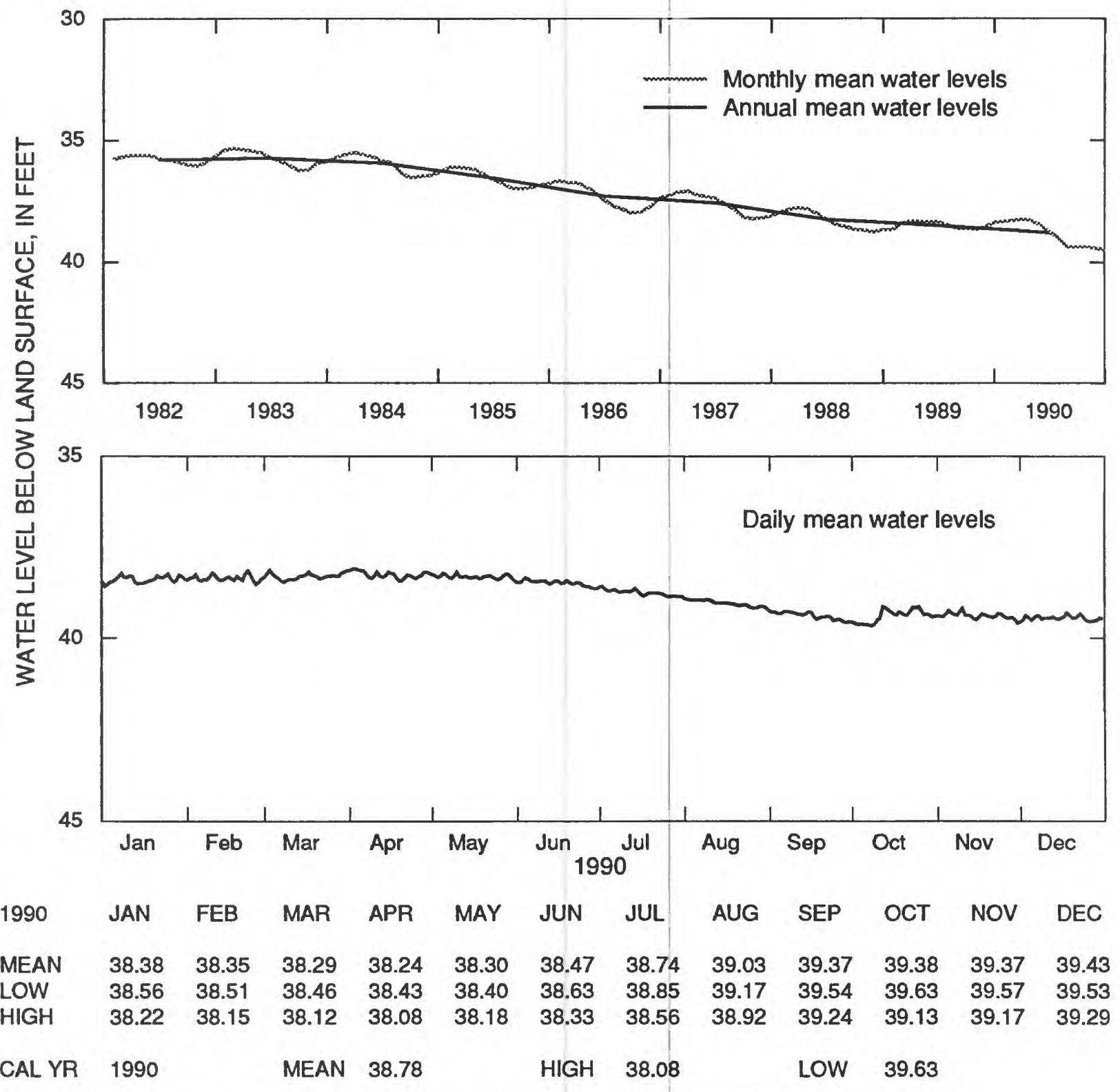

Figure 91.--Water level in observation well 21U004, Laurens County. 
324209082430201 Local number, $24 \mathrm{~V} 001$.

LOCATION.-Lat $32^{\circ} 42^{\circ} 09^{\prime \prime}$, long $82^{\circ} 43^{\prime} 02^{\prime \prime}$, Hydrologic Unit 03070107 , about $500 \mathrm{ft}$ west of Georgia Highway $15,1.8 \mathrm{mi}$ south of intersection of Georgia Highways 15 and 57, at Georgia Forestry Commission Firetower.

Owner: U.S. Geological Survey, test well 1.

AQUIFER.--Midville aquifer system.

WELL CHARACTERISTICS.--Drilled observation well, diameter 6 in., depth $1,780 \mathrm{ft}$, cased to $1,120 \mathrm{ft}$, screened intervals, $1,120-1,140 \mathrm{ft}, 1,260-1,280 \mathrm{ft}$, and $1,320-1,340 \mathrm{ft}$.

DATUM.--Altitude of land-surface datum is $355 \mathrm{ft}$.

Measuring point: Top of recorder shelf, $3.0 \mathrm{ft}$ above land-surface datum.

REMARKS.--Borehole geophysical survey conducted July 15 and August 18, 1980. Water-quality analysis August 29,

1980.

PERIOD OF RECORD.--September 1980 to current year.

EXTREMES FOR PERIOD OF RECORD.--Highest water level, $129.30 \mathrm{ft}$ below land-surface datum, March 5, 1981; lowest,

$138.15 \mathrm{ft}$ below land-surface datum, October 8,1990 .

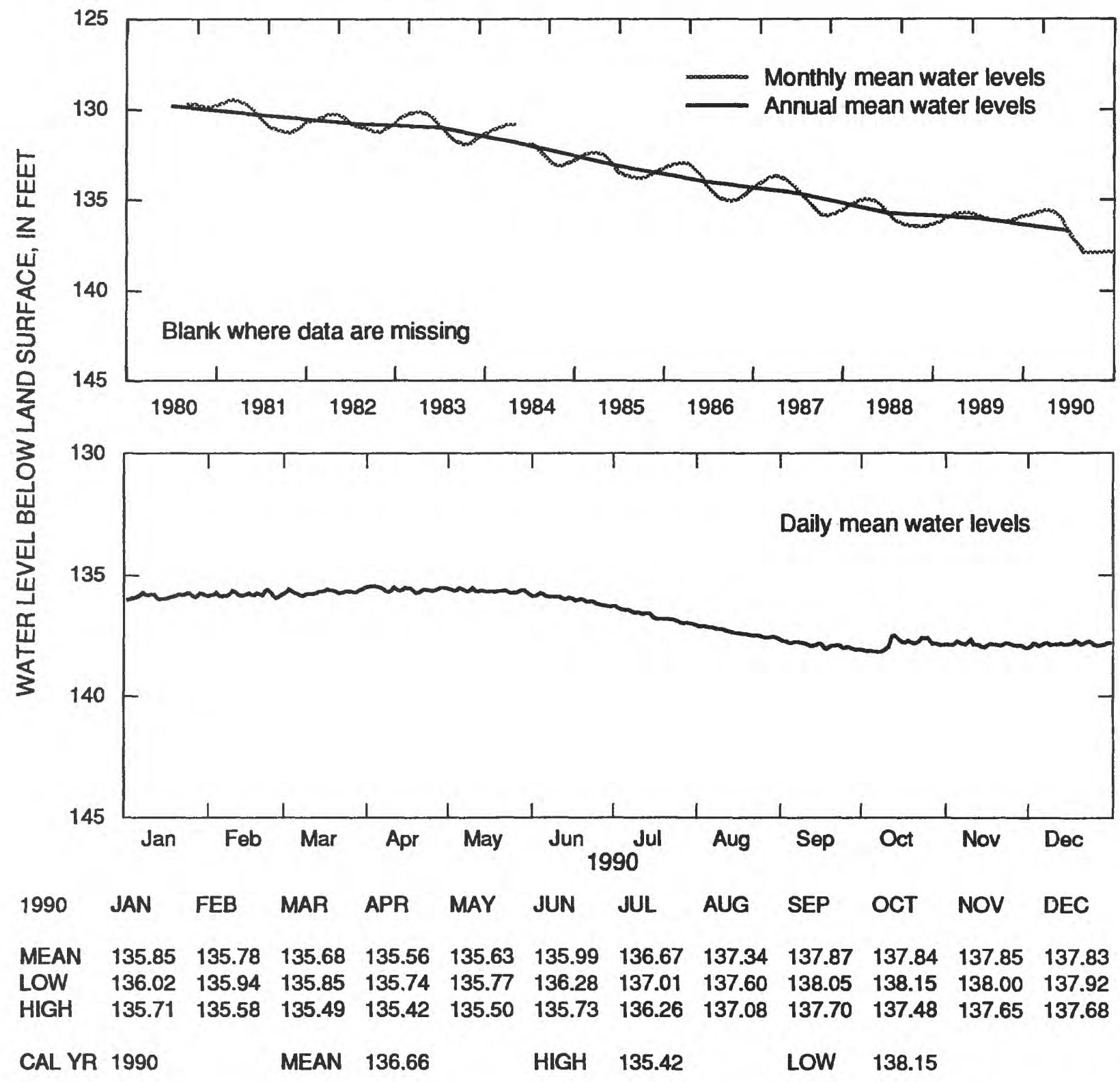

Figure 92.--Water level in observation well 24V001, Johnson County. 
325232082131501 Local number, $28 X 001$.

LOCATION.--Lat 32 $52^{\prime} 32^{\prime \prime}$, long $82^{\circ} 13^{\prime} 15^{\prime \prime}$, Hydrologic Unit 03060201, 4.2 mi north of Midville off Georgia Highway 56 at Southeastern Experiment Station.

Owner: U.S. Geological Survey, Midville Experiment Station 1.

AQUIFER.--Midville aquifer system.

WELL CHARACTERISTICS.--Drilled observation well, diameter 4 in., depth 1,045 ft, cased to 1,025 ft, screen to $1,045 \mathrm{ft}$.

DATUM.--Altitude of land-surface datum is $269 \mathrm{ft}$.

Measuring point: Top of recorder shelf, $3.04 \mathrm{ft}$ above land-surface datum.

REMARKS.--Borehole geophysical survey conducted March 8 and April 22, 1980. Water-quality analyses May 23, 1980. PERIOD OF RECORD.--June 1980 to current year.

EXTREMES FOR PERIOD OF RECORD.--Highest water level, $49.07 \mathrm{ft}$ below land-surface datum, June 4, 1980; lowest, $59.91 \mathrm{ft}$ below land-surface datum, November 30, 1990.

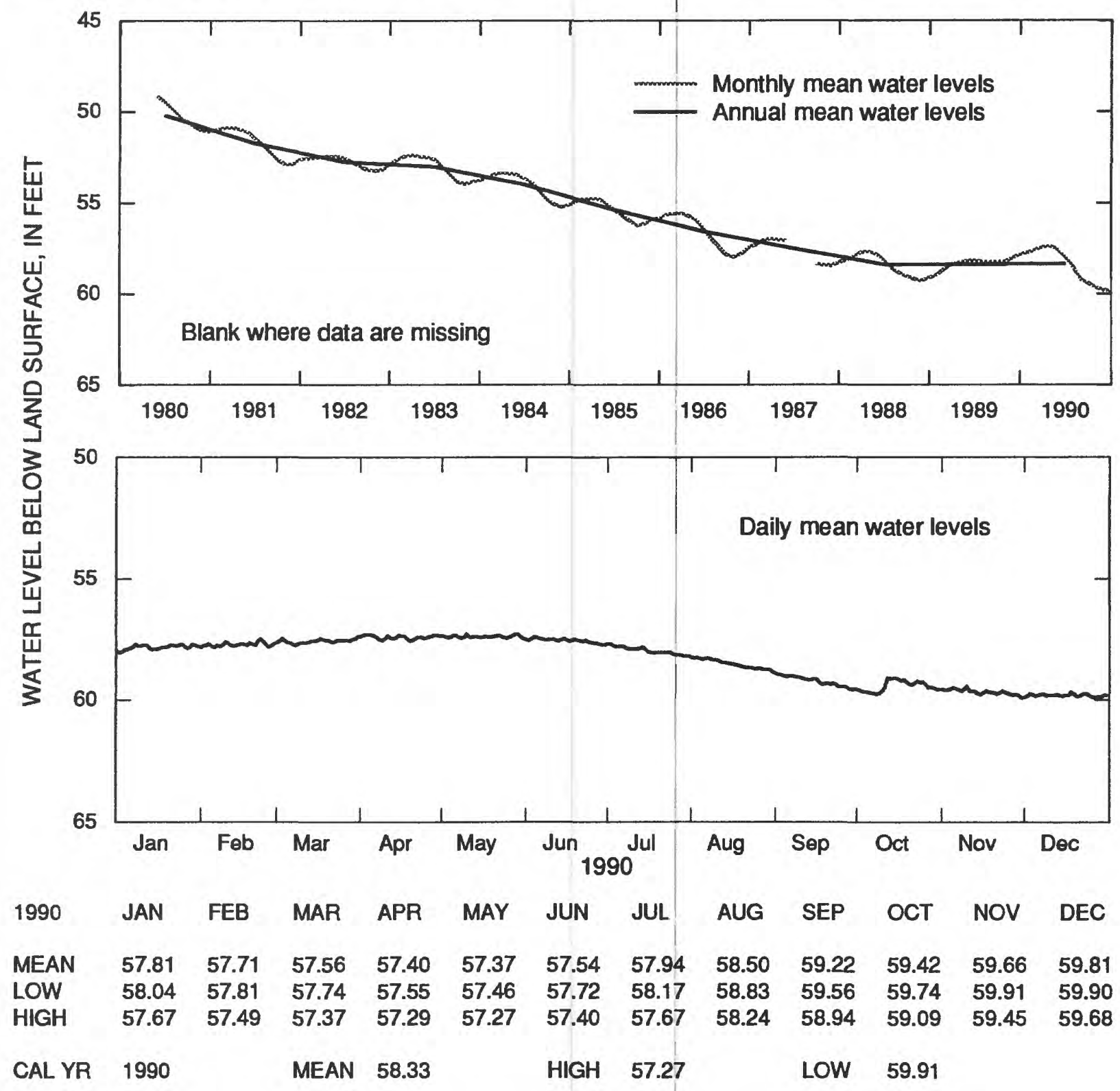

Figure 93.--Water level in observation well 28X001, Burke County. 


\section{Dublin-Midville aquifer system}

The water level in the Dublin-Midville aquifer system is monitored in two wells, both of which are included in this report (fig. 86). Water levels in wells tapping the Dublin-Midville aquifer system in Richmond County are influenced primarily by precipitation and by local pumping (Gorday, 1985, p. 28). The annual mean water level in well 30AA04 (fig. 94), near McBean in southern Richmond County, was about $0.7 \mathrm{ft}$ higher in 1990 than in 1989, continuing an upward trend that began in 1988. This rise may be the result of increased precipitation and decreased pumping. The sharp rise in water level in October that can be seen in the hydrograph for well 30AA04 (fig. 94) was possibly caused by an increase in pressure within the aquifer system that resulted from heavy rainfall and flooding in October (J.S. Clarke, U.S. Geological Survey, oral commun., 1991). (See precipitation graph for Augusta, fig. 7.)

At Sandersville, Washington County, the water level in the Dublin-Midville aquifer system is influenced primarily by local pumping. During 1990, the annual mean water level in well $23 \times 027$ (fig. 95) was about $5.0 \mathrm{ft}$ lower than in 1989, continuing the downward trend that has been observed since monitoring began in 1985. A record-low daily mean water level was recorded in well 23 X027 in October that was about $3.9 \mathrm{ft}$ lower than the previous record low. 
331711081573701 Local number, 30AA04.

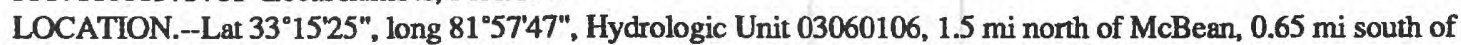

Little McBean Creek, 0.5 mi west of Georgia Highway 56.

Owner: Richmond County water system, USGS McBean 2.

AQUIFER.--Dublin-Midville aquifer system.

WELL CHARACTERISTICS.--Drilled unused municipal well, diameter 6 in., depth $496 \mathrm{ft}$, cased to $174 \mathrm{ft}$, screened intervals, $174-192 \mathrm{ft}, 299-319 \mathrm{ft}, 341-372 \mathrm{ft}$, and $393-434 \mathrm{ft}$.

DATUM.--Altitude of land-surface datum is $293 \mathrm{ft}$.

Measuring point: Top of 6 in. casing, $1.5 \mathrm{ft}$ above land-surface datum.

REMARKS.--Borehole geophysical survey conducted October 23, 1967. Water-quality sample collected November 26,

1967.

PERIOD OF RECORD.--June 1979 to current year.

EXTREMES FOR PERIOD OF RECORD.--Highest water level, $116.70 \mathrm{ft}$ below land-surface datum, May 30, 1984; lowest,

$129.61 \mathrm{ft}$ below land-surface datum, August 28, 1988.

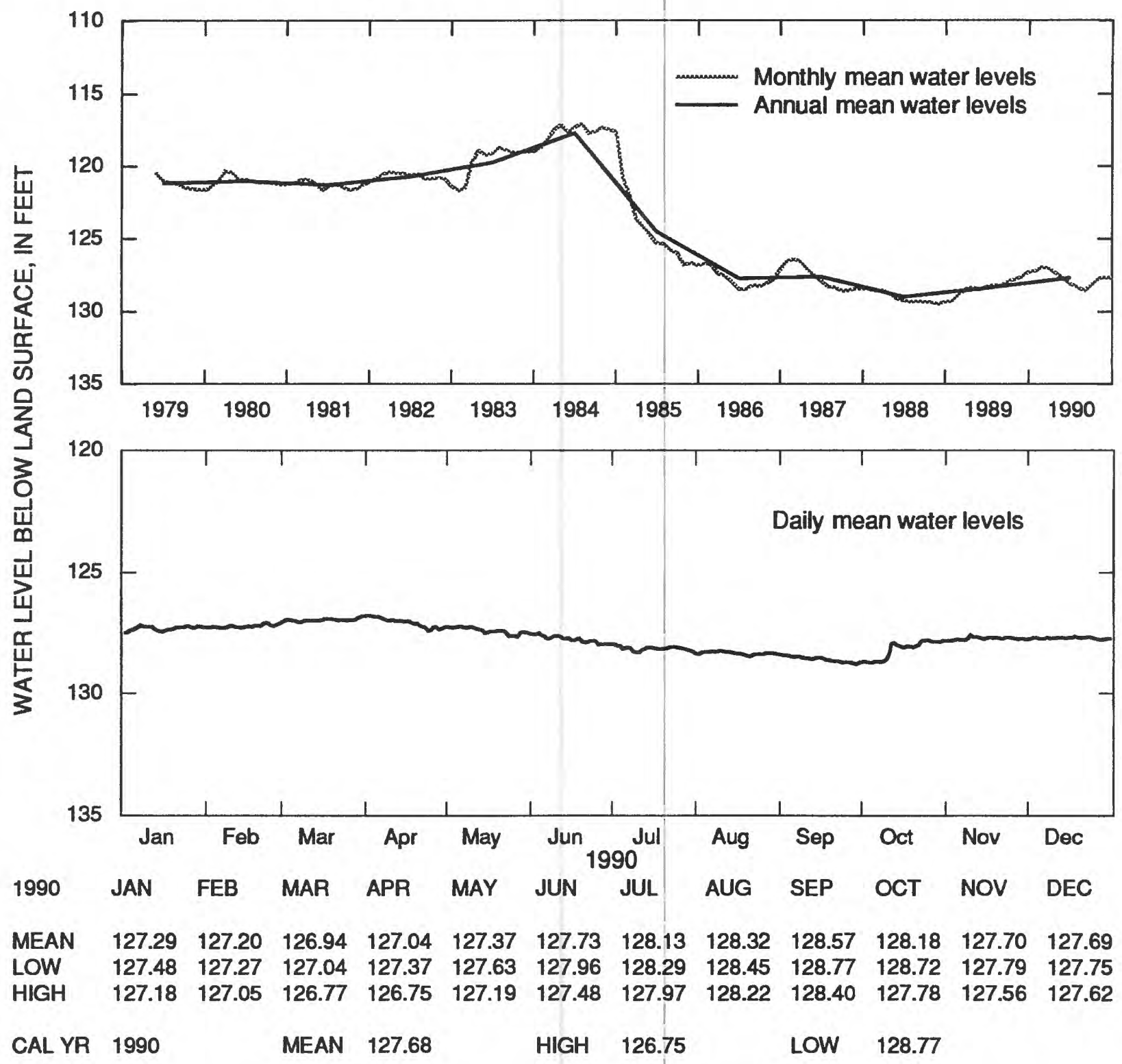

Figure 94.--Water level in observation well 30AA04, Richmond County. 
325848082480901 Local number, $23 \times 027$.

LOCATION.-Lat 32 $58^{\circ} 48^{\prime \prime}$, long $82^{\circ} 48^{\prime} 08^{\prime \prime}$, Hydrologic Unit $03070102,3,000 \mathrm{ft}$ south of the intersection of Georgia Highway 24 and Jordon Mill Road, and 3,100 ft south of the courthouse in Sandersville, east side of railroad.

Owner: City of Sandersville, well 8.

AQUIFER--Dublin-Midville aquifer system.

WELL CHARACTERISTICS.--Drilled unused municipal well, diameter 8 in., depth $750 \mathrm{ft}$, cased to $480 \mathrm{ft}$, screened intervals, $480-485 \mathrm{ft}, 605-610 \mathrm{ft}, 650-655 \mathrm{ft}, 695-700 \mathrm{ft}$, and $740-745 \mathrm{ft}$.

DATUM.-Altitude of land-surface datum is $450 \mathrm{ft}$.

Measuring point: Top of recorder shelf, $3.2 \mathrm{ft}$ above land-surface datum.

REMARKS.--Borehole geophysical survey conducted March 14, 1985. Well sounded to $672 \mathrm{ft}$ on March 14, 1985. Lower screens probably caved.

PERIOD OF RECORD.--March 14, 1985, to current year.

EXTREMES FOR PERIOD OF RECORD.--Highest water level, $227.68 \mathrm{ft}$ below land-surface datum, April 9, 1985; lowest, $249.83 \mathrm{ft}$ below land-surface datum, October $5,1990$.

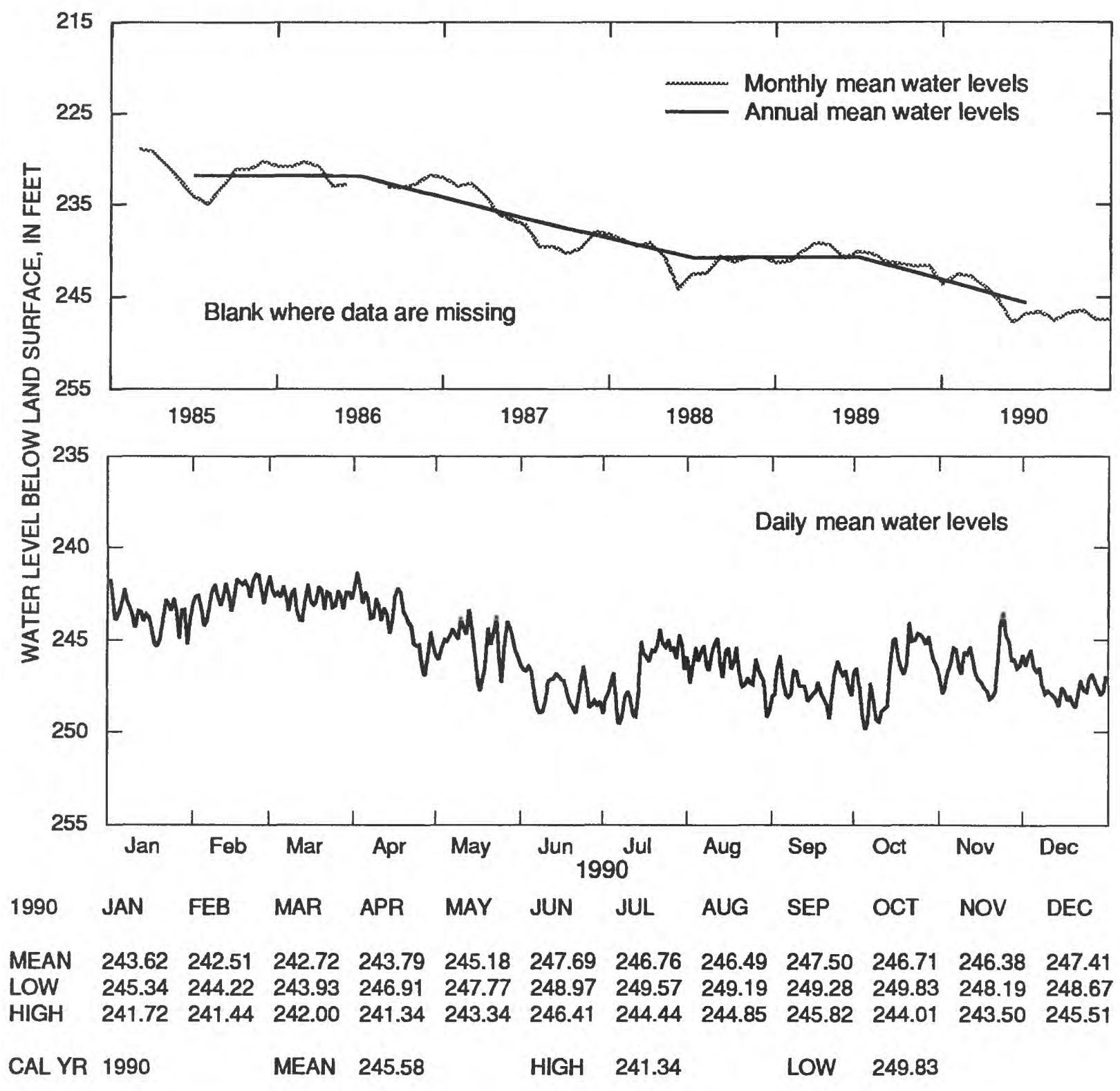

Figure 95.--Water level in observation well 23X027, Washington County. 


\section{Paleozoic Rock Aquifers}

The water level in an unnamed Paleozoic rock aquifer in Walker County is monitored in well 03PP01 (figs. 96 and 97). In this area, water levels in wells tapping the Paleozoic rock aquifers are affected primarily by precipitation and local pumping. The effect of precipitation on water levels in areas having thin soil cover over aquifers having secondary openings (fractures or solution openings) can be seen in the hydrograph of daily mean water levels for well 03PP01 (fig. 97); the sharp water-level rises correspond to increases in precipitation (see precipitation graph for the Rome station, fig. 4). The annual mean water level in well 03PP01 (fig. 97) was about $1.1 \mathrm{ft}$ lower in 1990 than in 1989, reversing an upward trend that began in 1987. 


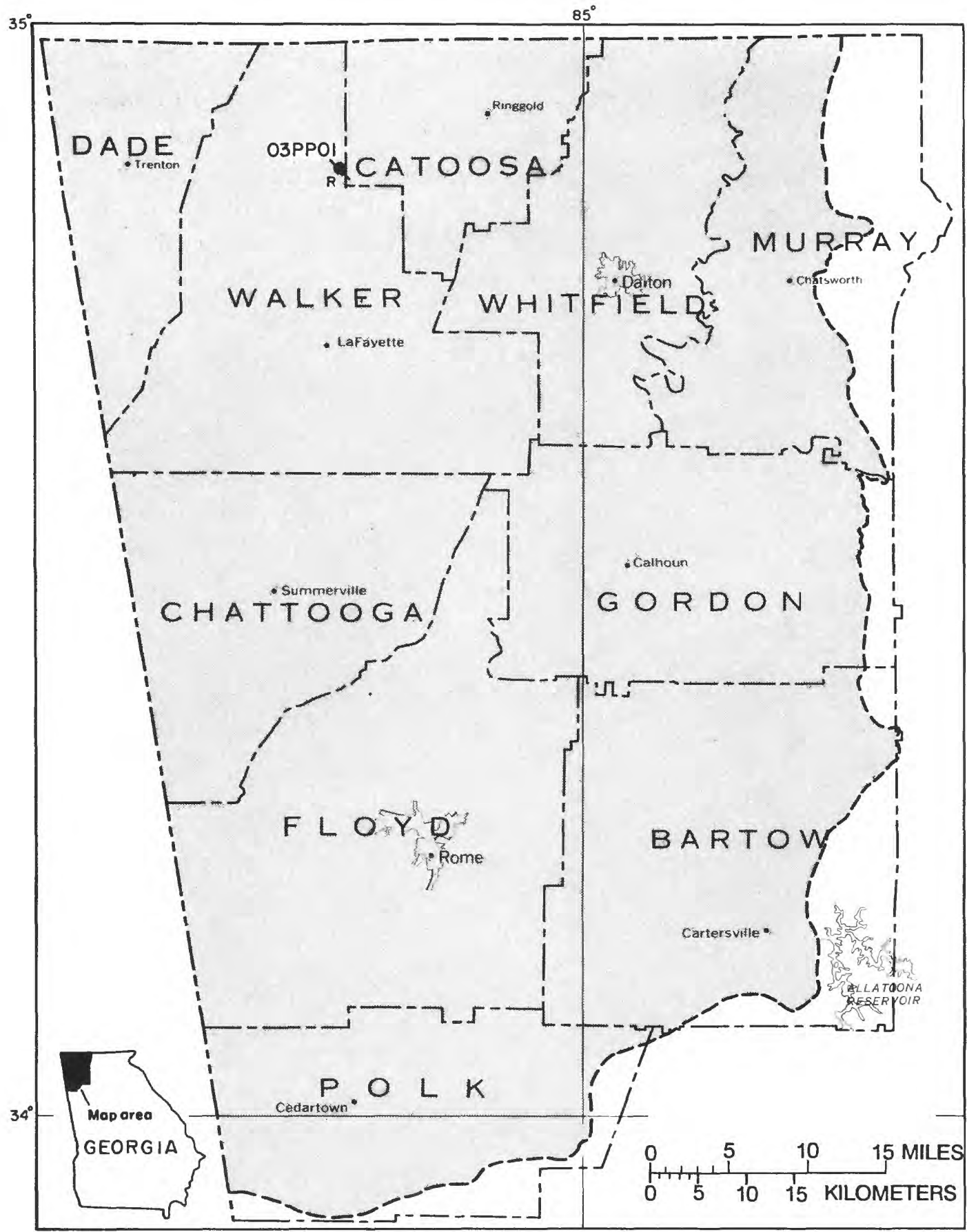

EXPLANATION

AREA OF PALEOZOIC ROCK

O3PPOI OBSERVATION WELL AND AOUIFER

IDENTIFICATION NUMBER--

Equipped with recorder, hydrograph included in this report

Figure 96.--Location of an observation well in a Paleozoic rock aquifer. 
345403085160001 Local number, $03 \mathrm{PP} 01$.

LOCATION.--Lat $34^{\circ} 54^{\prime} 08^{\prime \prime}$, long $85^{\circ} 16^{\prime} 00^{\prime \prime}$, Hydrologic Unit 06020001, Chickamauga and Chattanooga National Military

Park.

Owner: National Park Service, Chickamauga Battlefield Park.

AQUIFER.-Paleozoic Rock (Chickamauga Limestone).

WELL CHARACTERISTICS.--Cable-tooled, observation well, diameter 8 in., depth $72 \mathrm{ft}$, cased to $11 \mathrm{ft}$, open hole.

DATUM.-Altitude of land-surface datum is $730 \mathrm{ft}$.

Measuring point: Pointer on recorder shelf, $2.09 \mathrm{ft}$ above land surface.

REMARKS.--Well sounded October 18, 1977. Water levels for period of missing record, August 8-21, were estimated.

PERIOD OF RECORD.--1977 to current year.

EXTREMES FOR PERIOD OF RECORD.--Highest water level, $1.97 \mathrm{ft}$ below land-surface datum, March 9, 1978; lowest,

$21.70 \mathrm{ft}$ below land-surface datum, August 5, 1978.

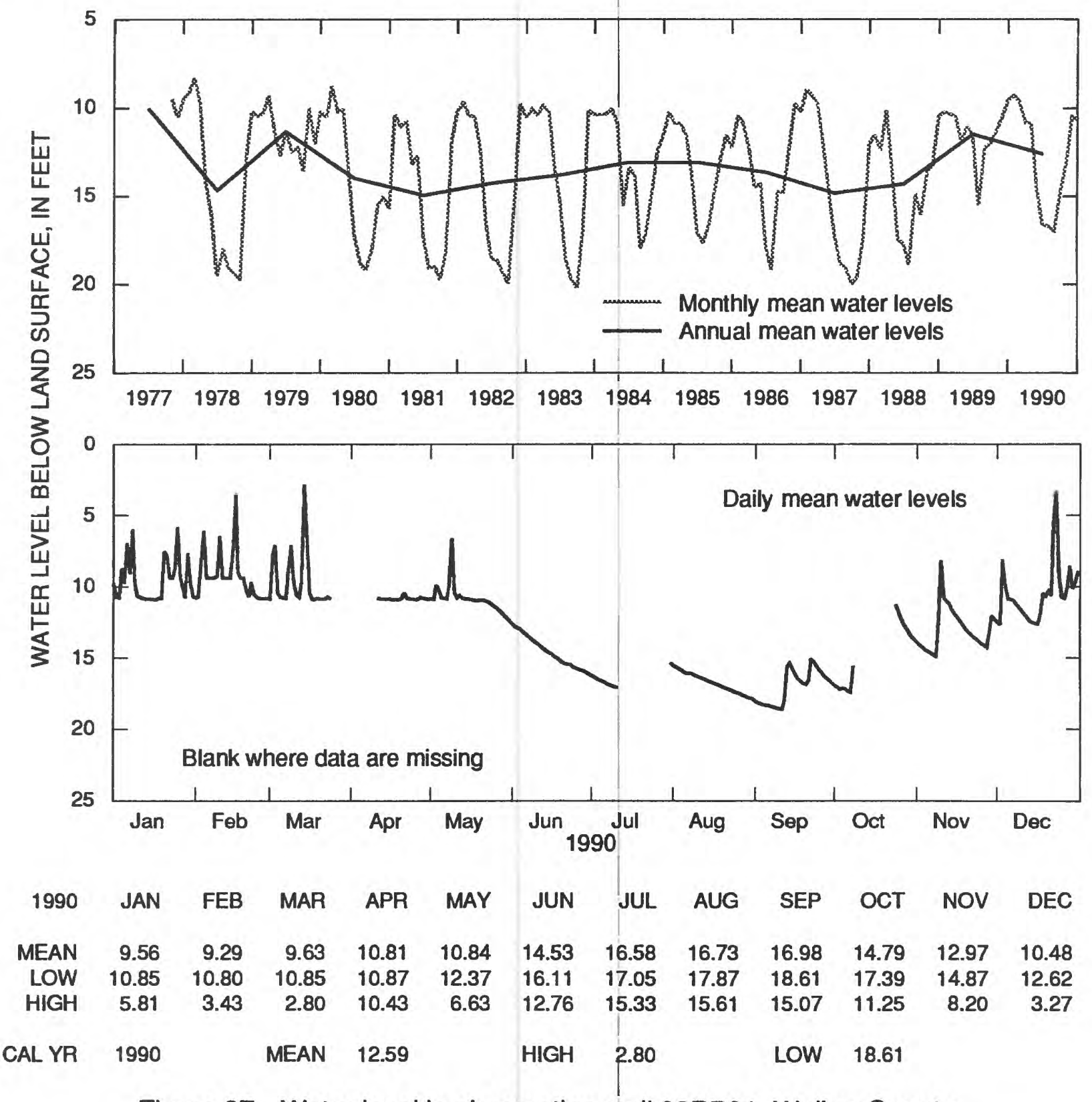

Figure 97.--Water level in observation well 03PP01, Walker County. 


\section{Crystalline-Rock Aquifers}

Water levels in the crystalline-rock aquifers are monitored in nine wells, four of which are summarized in this report (fig. 98). Water levels in wells tapping the crystalline-rock aquifers are affected mainly by precipitation and evapotranspiration, and locally by pumping. As in the Paleozoic rock aquifers, precipitation can cause rapid rises in water levels in areas of thin soil cover over aquifers having secondary openings; this effect can be seen in the hydrograph for well 11FF04 (fig. 101). Generally, ground-water levels rise with the onset of late winter rains and reduced evapotranspiration, and reach their highest levels in March or April. Evapotranspiration and decreased rainfall during spring and early summer cause water levels to decline to annual lows, which generally occur in October or November.

The annual mean water levels in wells 10DD02 (fig. 99) in Fulton County and $19 \mathrm{HH} 12$ (fig. 100) in Madison County were about 1.2 and $1.8 \mathrm{ft}$ higher than in 1989, respectively, as a result of above-normal precipitation. This water-level rise in both wells continued an upward trend that began in 1988. The annual mean water levels in wells 11FF04 (fig. 101) in DeKalb County and 21BB04 (fig. 102) in Greene County were slightly lower and about $0.8 \mathrm{ft}$ lower than in 1989, respectively. Despite these variations, long-term trends are not apparent on the period-of-record hydrographs for either well. Although the annual mean water level was slightly lower in both wells than in 1989, record-high water levels were recorded in well 11FF04 (fig. 101) in March, and in well 21BB04 (fig. 102) in February, that were about 0.5 and $0.4 \mathrm{ft}$ higher than previous record highs, respectively. 

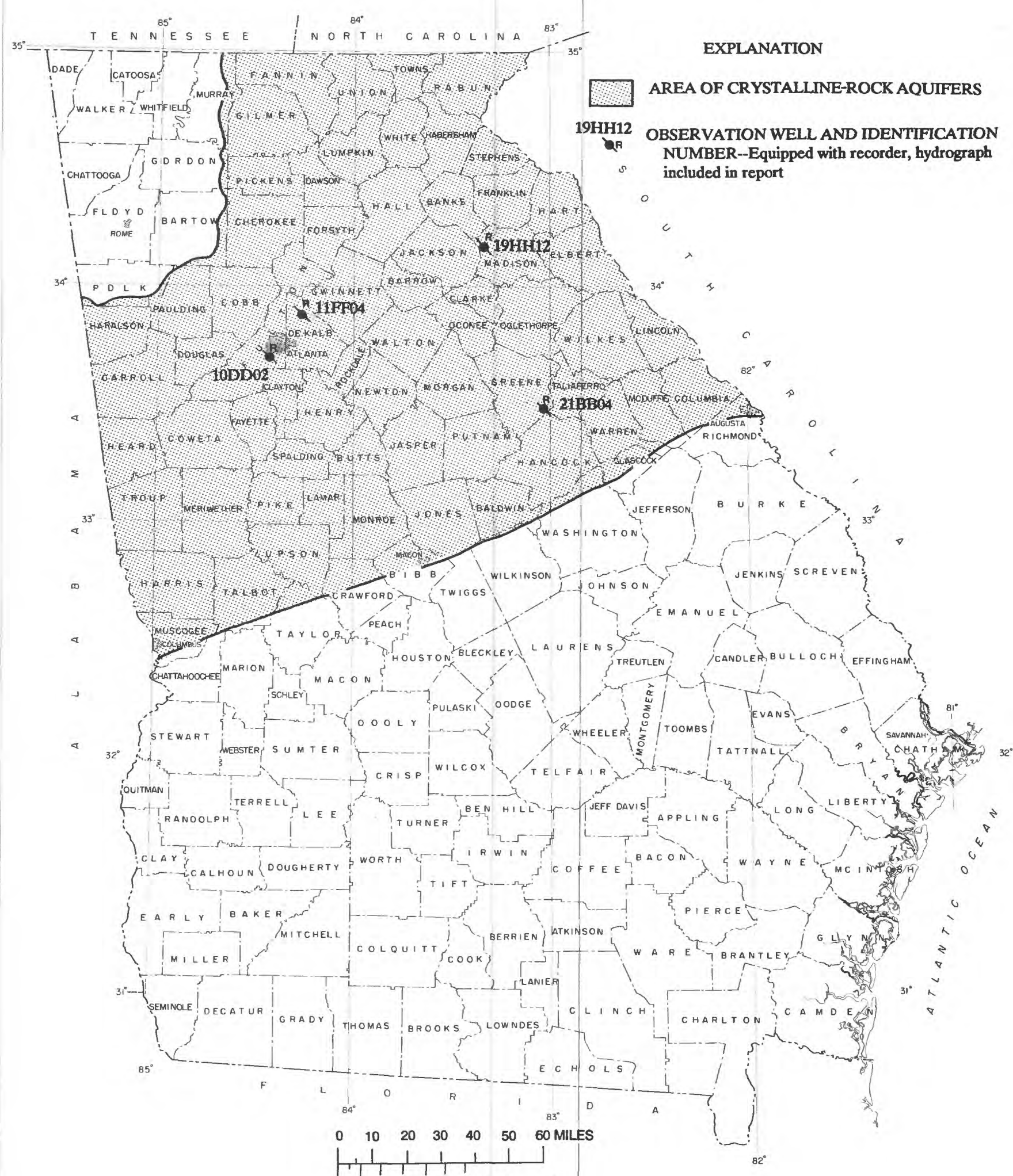

O 1020304050 60 KILOMETERS

Figure 98.--Locations of observation wells completed in crystalline-rock aquifers. 
334207084254801 Local number, 10DD02.

LOCATION.--Lat $33^{\circ} 42^{\prime} 07^{\prime \prime}$, long $84^{\circ} 25^{\prime} 48^{\prime \prime}$, Hydrologic Unit 03130002, $100 \mathrm{ft}$ east of parking lot at main entrance.

Owner: U.S. Army, Fort McPherson.

AQUIFER.--Crystalline rock (Biotite gneiss).

WELL CHARACTERISTICS.--Drilled, unused supply well, diameter $12 \mathrm{in}$., depth $338 \mathrm{ft}$, cased to $41 \mathrm{ft}$, open hole.

DATUM.-Altitude of land-surface datum is $1,013 \mathrm{ft}$.

Measuring point: Top of recorder shelf, $3.45 \mathrm{ft}$ above land-surface datum..

REMARKS.-Well pumped and sounded February 14, 1976, to a depth of $338 \mathrm{ft}$. Well pumped and water sample collected

November 26, 1985. Borehole geophysical survey conducted November 19, 1974.

PERIOD OF RECORD.--November 1973 to current year.

EXTREMES FOR PERIOD OF RECORD.--Highest water level, $0.10 \mathrm{ft}$ below land-surface datum, March 30, 1980; lowest, $10.95 \mathrm{ft}$ below land-surface datum, September 2, 1988.

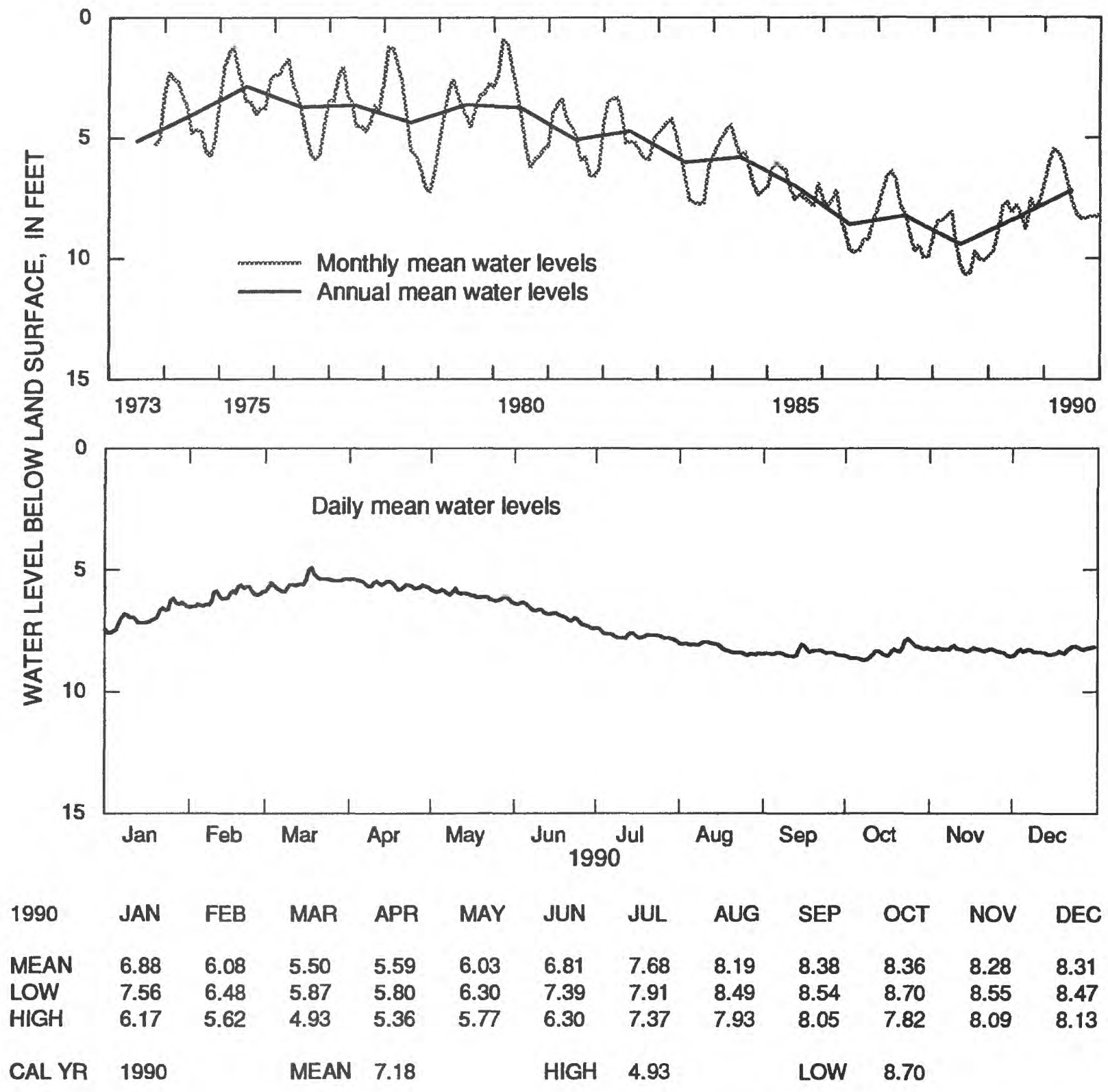

Figure 99.--Water level in observation well 10DD02, Fulton County. 
341020083201701 Local number, $19 \mathrm{HH} 12$.

LOCATION.--Lat $34^{\circ} 10^{\prime} 20^{\prime \prime}$, long $83^{\circ} 20^{\prime} 17^{\prime \prime}$, Hydrologic Unit $03060104,2.5$ mi west of the intersection of Ga.

Highways 98 and 106 in $\mathrm{Dla}$, approximately $0.8 \mathrm{mi}$ south of $\mathrm{Ga}$. Highway 98 .

Owner: Meadowlake Estates.

AQUIFER.--Crystalline rock.

WELL CHARACTERISTICS.--Drilled, unused supply well, diameter 6 in., depth $185 \mathrm{ft}$, cased to $50 \mathrm{ft}$, open hole.

DATUM--Altitude of land-surface datum is $800 \mathrm{ft}$.

Measuring point: Top of recorder shelf, $3.0 \mathrm{ft}$ above land-surface datum.

REMARKS.--Pump test conducted April 4-5, 1984. Borehole geophysical survey conducted October 31, 1983, and

November 16, 1983.

PERIOD OF RECORD.--October 1983 to current year.

EXTREMES FOR PERIOD OF RECORD.--Highest water level, $6.69 \mathrm{ft}$ below land-surface datum, April 14, 1984; lowest, $15.56 \mathrm{ft}$ below land-surface datum, September 2-3, 1988.

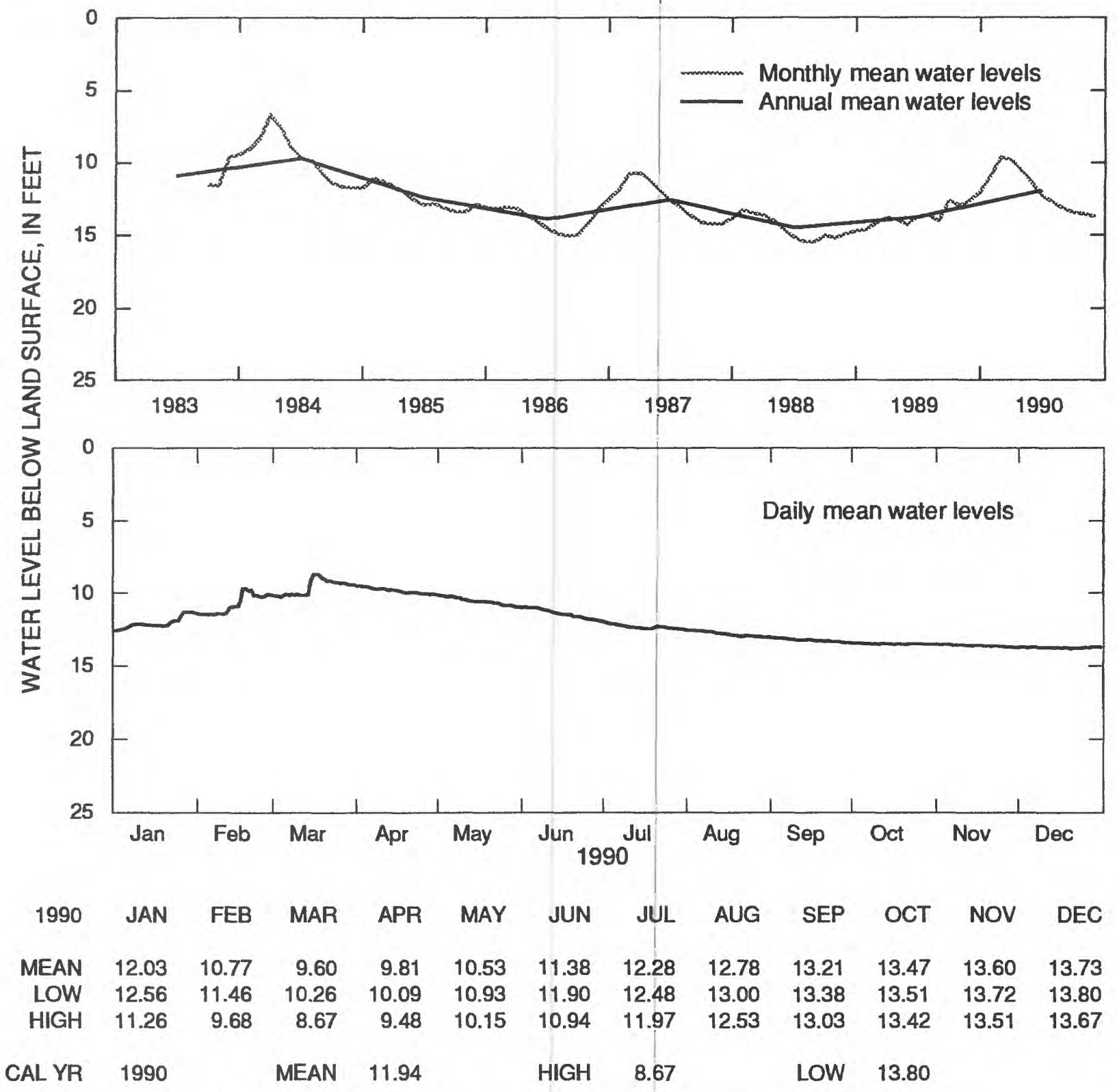

Figure 100.-Water level in observation well $19 \mathrm{HH} 12$, Madison County. 
335517084164001 Local number, 11FF04.

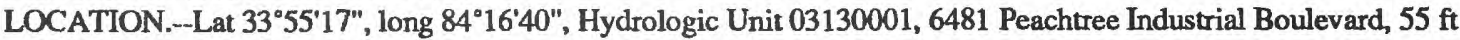
south of southeastern corner of building.

Owner: U.S. Geological Survey

AQUIFER.--Crystalline rock.

WELL CHARACTERISTICS.--Drilled, observation well, diameter 6 in., depth $620 \mathrm{ft}$, cased to $36 \mathrm{ft}$, open hole.

DATUM.--Altitude of land-surface datum is $950 \mathrm{ft}$.

Measuring point: Top of recorder shelf, $3.0 \mathrm{ft}$ above land-surface datum.

REMARKS.--Borehole geophysical survey conducted April 18, 1980.

PERIOD OF RECORD.-February 1980 to current year.

EXTREMES FOR PERIOD OF RECORD.--Highest water level, $4.98 \mathrm{ft}$ below land-surface datum, March 17, 1990; lowest,

$7.66 \mathrm{ft}$ below land-surface datum, July 20, 1988 .

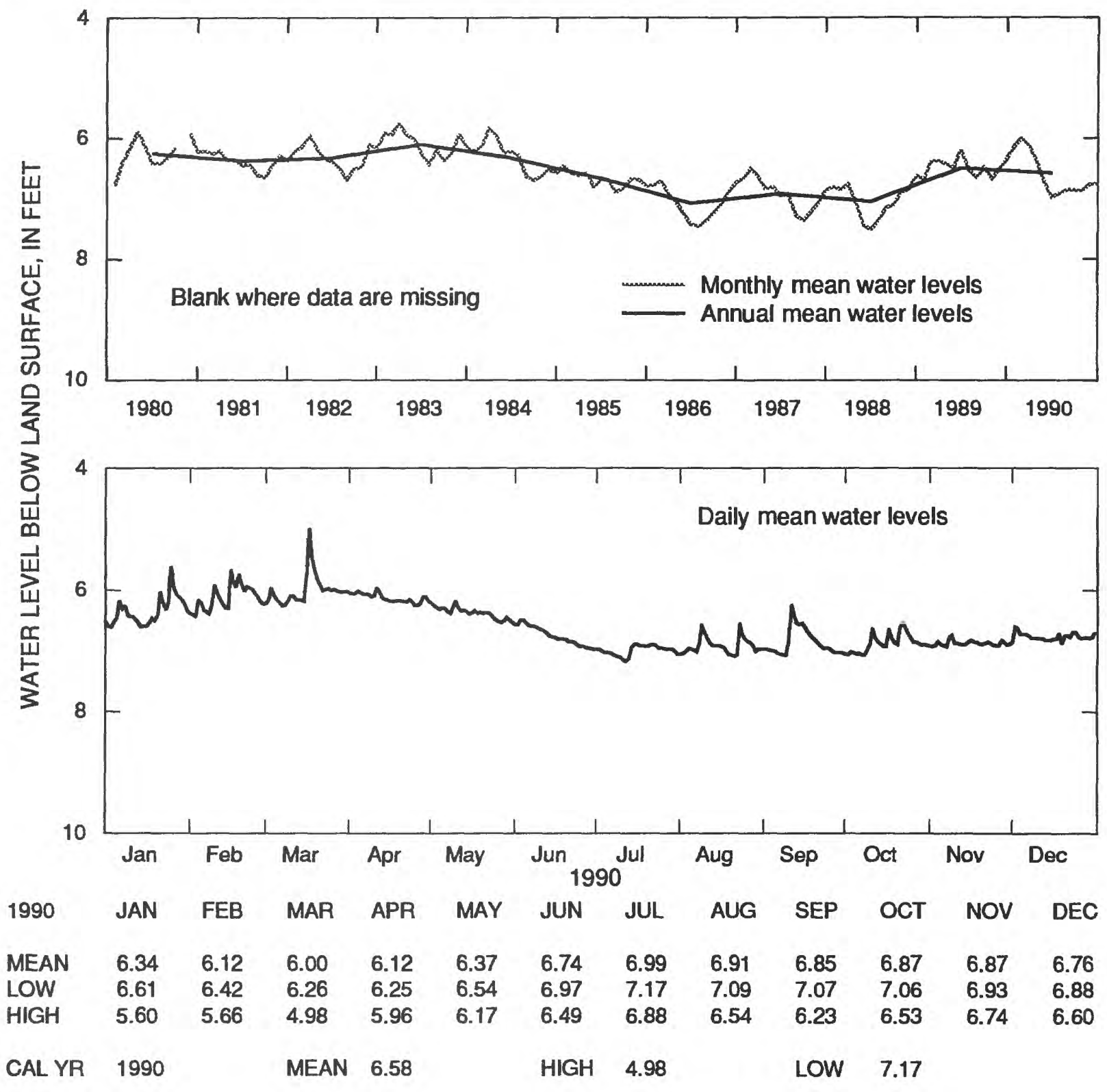

Figure 101.--Water level in observation well 11FF04, DeKalb County. 
332808083010201 Local number, $21 \mathrm{BB} 04$.

LOCATION.--Lat $33^{\circ} 28^{\prime} 08^{\prime \prime}$, long $83^{\circ} 01^{\prime} 02^{\prime \prime}$, Hydrologic Unit $03070101,1.1$ mi east of Georgia Highway 15 at White

Plains, and $50 \mathrm{ft}$ north of the centerline of Log Cabin Road.

Owner: Charles Veazey.

AQUIFER.--Crystalline rock.

WELL CHARACTERISTICS.--Drilled, unused supply well, diameter 6 in., depth $497 \mathrm{ft}$, cased to $15 \mathrm{ft}$, open hole.

DATUM.--Altitude of land-surface datum is $675 \mathrm{ft}$.

Measuring point: Top of recorder shelf, $2.5 \mathrm{ft}$ above land-surface datum.

REMARKS.--Borehole geophysical survey conducted March 13, 1987. Water levels for period of missing record,

March 10, July 2-9, and October 24-29, were estimated.

PERIOD OF RECORD.--March 13, 1987, to current year.

EXTREMES FOR PERIOD OF RECORD.--Highest water level, $0.55 \mathrm{ft}$ above land-surface datum, February 20, 1990; lowest,

$7.58 \mathrm{ft}$ below land-surface danum, December 7, 1987.

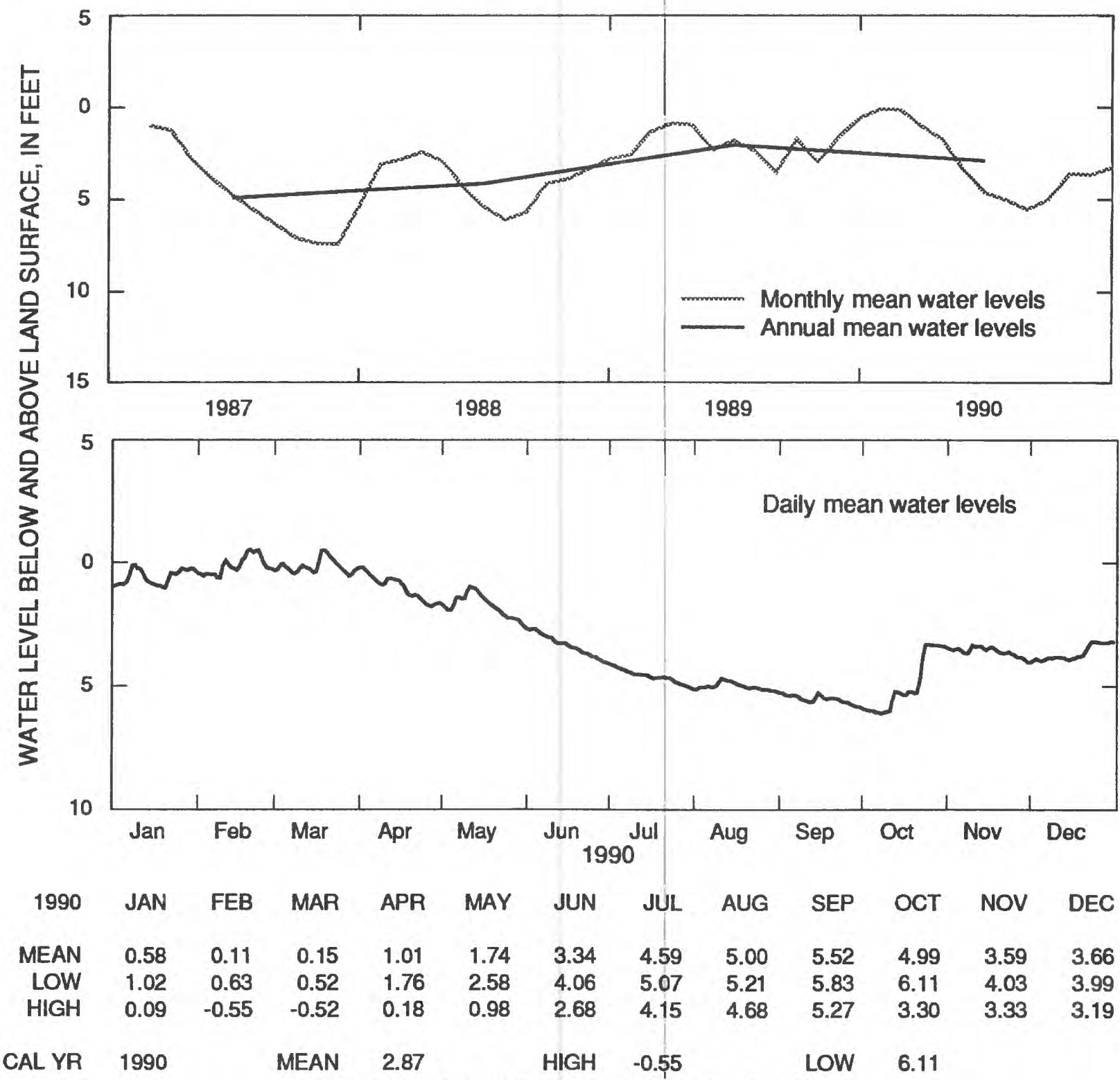

[Negative values indicate level above land surface]

Figure 102.--Water level in observation well 21BB04, Greene County. 


\section{CHLORIDE CONCENTRATION IN THE FLORIDAN AQUIFER SYSTEM}

Chloride concentration in water from the Floridan aquifer system has been monitored periodically in coastal Georgia since the 1950's. During May 1990, water samples were collected from 143 wells that tap the Upper Floridan aquifer in the coastal area and were analyzed for chloride concentration. Results of these analyses were used to construct a map showing the distribution of chloride concentration in coastal Georgia (Cressler, 1991) (fig. 103). The general configuration of the map changed little since that of 1988 (Joiner and others, 1989). Of the 143 wells sampled in 1990, chloride-concentration graphs are shown for 13 of these wells (figs. 105, 107, and 108, table 3). Chloride concentration in water from the Upper Floridan aquifer in most of the coastal Georgia area is less than $40 \mathrm{mg} / \mathrm{L}$ (Clarke and others, 1990, p. 48), which is within the $250 \mathrm{mg} / \mathrm{L}$ drinking-water standard established by the Georgia Department of Natural Resources (1977) and the U.S. Environmental Protection Agency (1986). Chloride concentration in water from the Upper Floridan aquifer that exceeds drinking-water standards has been detected only in the Brunswick area (see fig. 106). Water in the Lower Floridan aquifer generally has high chloride concentrations throughout the coastal area, and therefore, is unsuitable for human consumption (Clarke and others, 1990, p. 48). Chloride concentrations in water from the Fernandina permeable zone at the base of the Lower Floridan aquifer have been as high as $30,000 \mathrm{mg} / \mathrm{L}$ (Krause and Randolph, 1989, p. 51).

Table 3.--Observation wells for which chloride concentration graphs are included in this report

\begin{tabular}{|c|c|c|c|}
\hline County & Aquifer & $\begin{array}{c}\text { Well } \\
\text { number }\end{array}$ & Well name \\
\hline Chatham & Upper Floridan & $37 Q 185$ & Hutchinson Island test well 1 \\
\hline Chatham & Lower Floridan & 380004 & Test well 4 \\
\hline Chatham & Lower Floridan & $38 Q 196$ & Test well 1 point 2 \\
\hline Chatham & Lower Floridan & 390017 & Test well 7 point 1 \\
\hline Chatham & Lower Floridan & 390018 & Test well 7 point 2 \\
\hline Glynn & Upper Floridan, lower water-bearing zone & $33 \mathrm{H} 127$ & Test well 3 \\
\hline Glynn & Upper Floridan, upper water-bearing zone & $33 \mathrm{H} 133$ & Test well 6 \\
\hline Glynn & Upper Floridan, upper water-bearing zone & $34 \mathrm{H} 132$ & Test well 2 \\
\hline Glynn & Lower Floridan, brackish-water zone & $34 \mathrm{H} 391$ & Test well 16 \\
\hline Glynn & Upper Floridan, upper water-bearing zone & $34 \mathrm{H} 393$ & Test well 17 \\
\hline Glynn & Lower Floridan, brackish-water zone & $34 \mathrm{H} 399$ & Test well 19 \\
\hline Glynn & Upper Floridan, lower water-bearing zone & $34 \mathrm{H} 403$ & Test well 24 \\
\hline Glynn & Upper Floridan, upper water-bearing zone & $34 \mathrm{H} 427$ & E.M. Champion well 2 \\
\hline
\end{tabular}




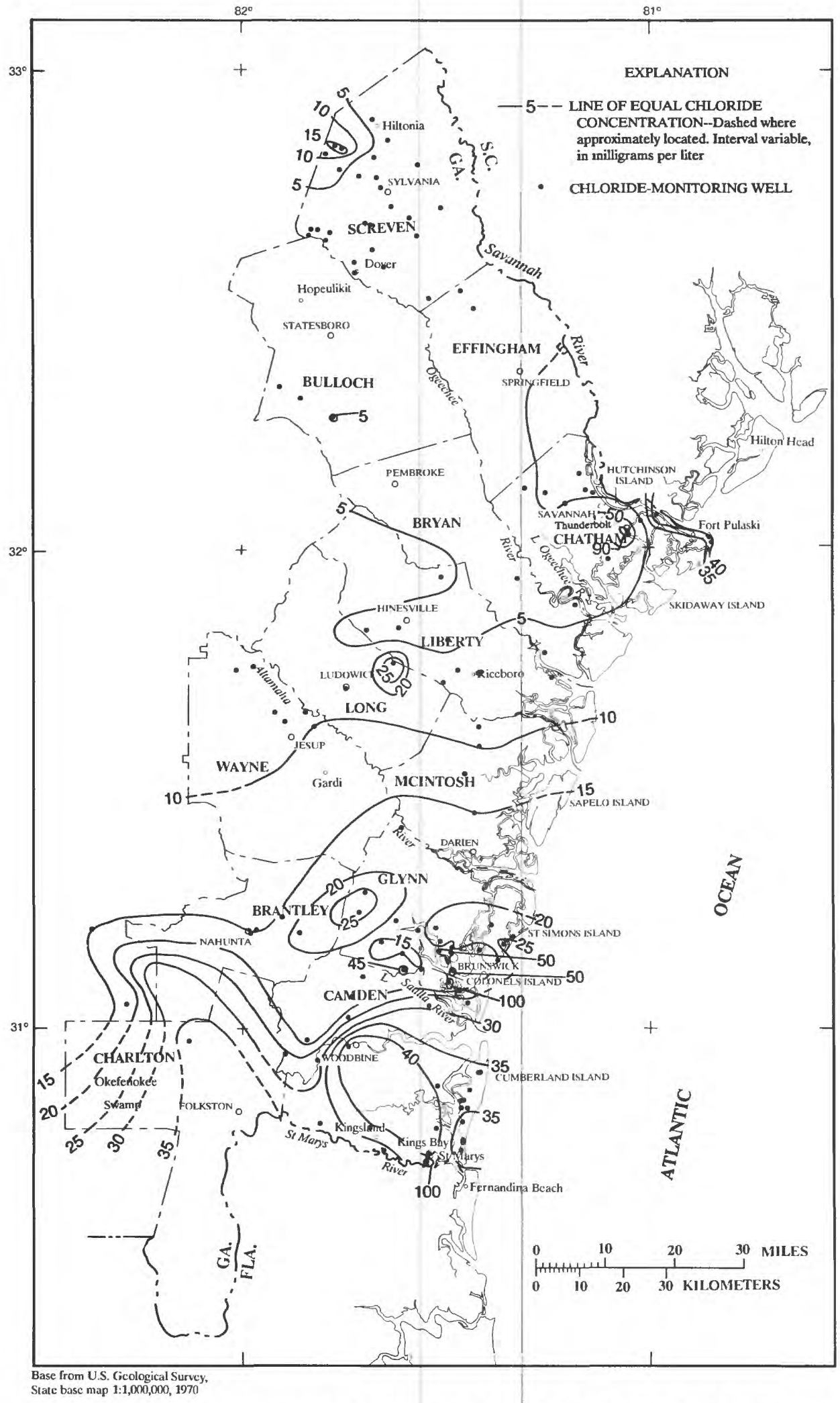

Figure 103.--Chloride concentration and locations of chloride-monitoring wells completed in the Upper Floridan aquifer in the coastal area, May 1990.

From Cressler (1991). 


\section{Savannah Area}

Saltwater has the potential to enter the Floridan aquifer system in the Savannah area by encroachment from the sea or to a lesser extent, by upconing (upward leakage) from deeper zones (Clarke and others, 1990, p. 48). Chloride concentration in the Upper Floridan aquifer in the Savannah area generally increases toward the eastern part of Chatham County (Joiner and others, 1989, p. 162). An anomalously high chloride concentration of $99 \mathrm{mg} / \mathrm{L}$ was measured in a well at Thunderbolt (fig. 103). High values have been noted in that area in the past and are possibly the result of a failed well casing in the area (J.S. Clarke, U.S. Geological Survey, oral commun., 1991).

Twelve wells are sampled on a monthly basis in Chatham County, five of which are summarized in this report (fig. 104). Data from these wells indicate that chloride concentration generally increases with depth below land surface in the Savannah area. This increase is shown by chloride graphs for one well tapping the Upper Floridan aquifer and four wells tapping the Lower Floridan aquifer (fig. 105). The chloride concentration in water from the Floridan aquifer system in the Savannah area has shown little change since monitoring began in 1968. Although long-term trends are not apparent, the chloride concentrations in three wells tapping deeper zones of the Lower Floridan aquifer showed an increase at the end of 1990: in well $38 \mathrm{Q} 196$, from 5,300 to $5,500 \mathrm{mg} / \mathrm{L}$; in well $39 \mathrm{Q} 017$, from 850 to $920 \mathrm{mg} / \mathrm{L}$; and in well 390018 , from 620 to $640 \mathrm{mg} / \mathrm{L}$ (fig. 105). 


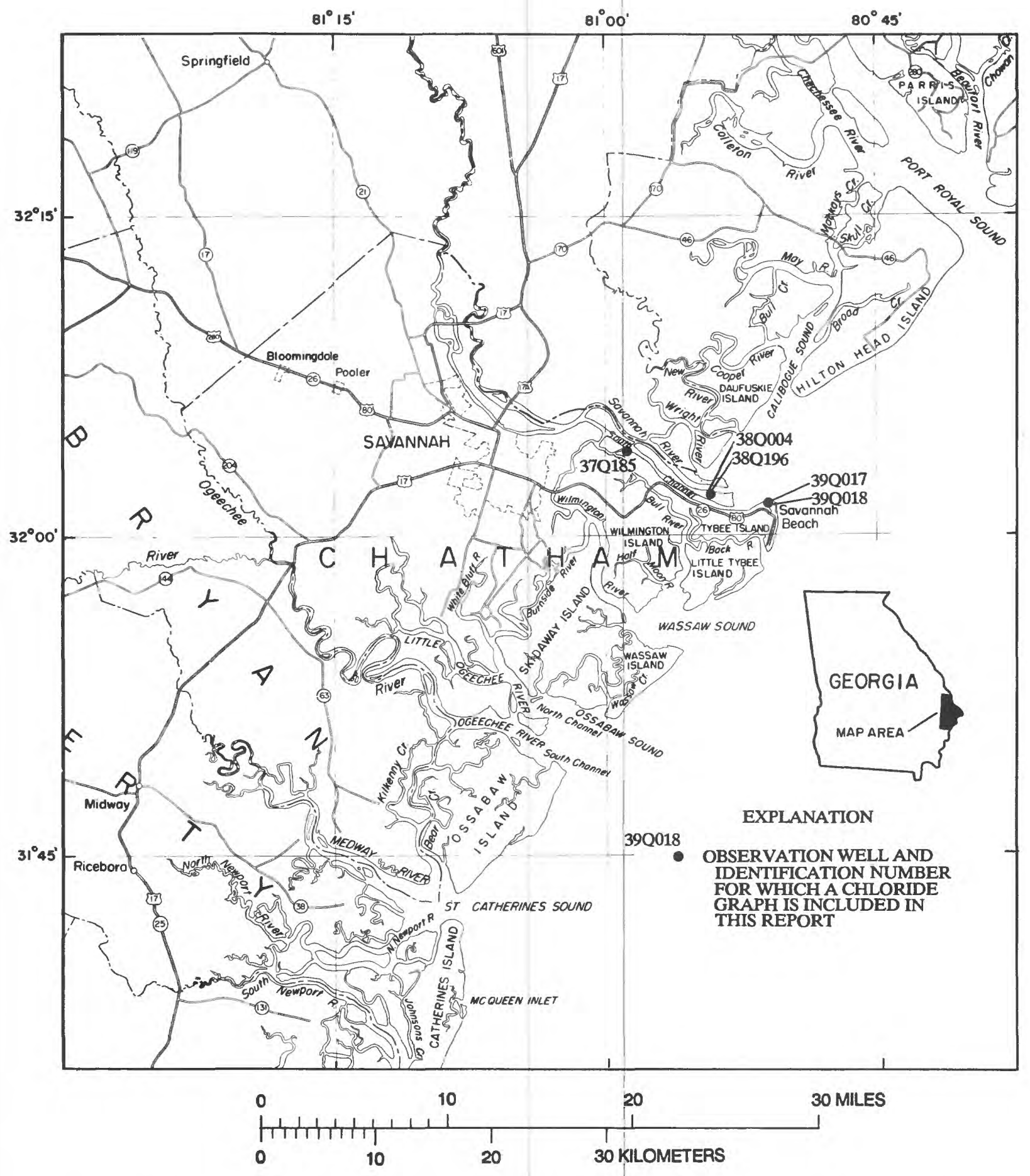

Figure 104.--Locations of chloride-monitoring wells completed in the Floridan aquifer system in the Savannah area. 


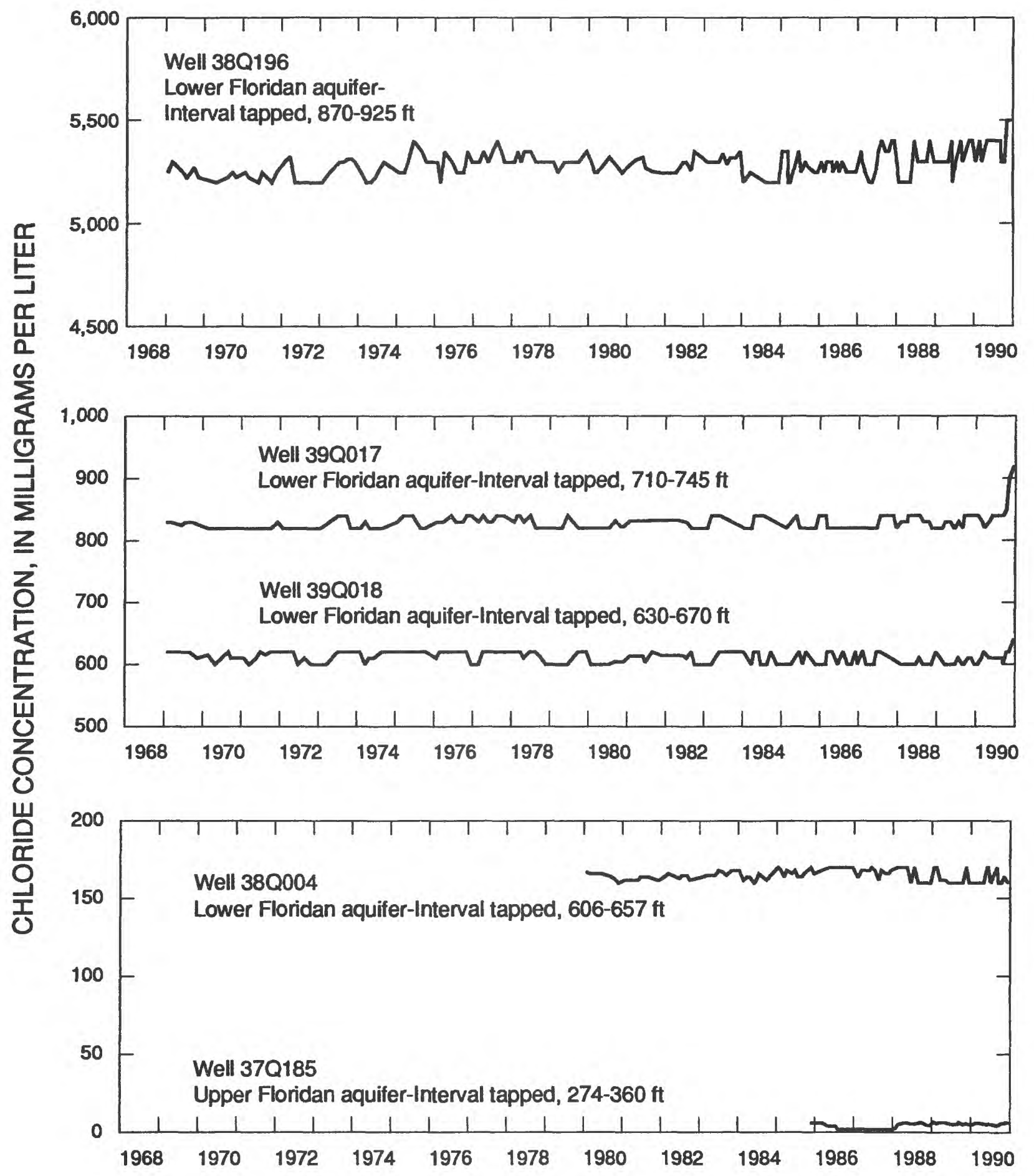

Figure 105.--Chloride concentrations in the Upper and Lower Floridan aquifers in the Savannah area. 


\section{Brunswick Area}

Since pumping began in the Brunswick area in the late 1800 's, ground-water withdrawal has lowered the water level in the Upper Floridan aquifer (Krause and Randolph, 1989). This water-level decline has allowed saltwater to migrate upward into the Upper Floridan aquifer in Brunswick from the Fernandina permeable zone, which is at the base of the Lower Floridan aquifer (Krause and Randolph, 1989, p. 51). Chloride concentrations in the upper water-bearing zone of the Upper Floridan aquifer are greater than 2,000 $\mathrm{mg} / \mathrm{L}$ at three known locations (fig. 106) (Krause and Randolph, 1989, p. 51).

About 80 wells in Glynn County, mostly in the Brunswick area, are pumped and sampled semi-annually for chloride analysis. Results of analysis of water from 46 wells tapping the upper water-bearing zone of the Upper Floridan aquifer during October-November 1990 were used to construct a chloride-concentration map for the Brunswick area (Joiner, 1991) (fig. 106). Although the configuration of the map has changed little since October 1989 (Peck and others, 1990), comparison of chloride-concentration maps from the years 1977 (U.S. Geological Survey, 1978, p. 77), 1984 (Clarke and others, 1985b, p. 141), and 1990 (fig. 106) shows an east-towest migration of water having high (greater than $1,500 \mathrm{mg} / \mathrm{L}$ ) chloride concentration in the northern Brunswick area. This comparison also shows a northward extension of high (greater than $500 \mathrm{mg} / \mathrm{L}$ ) chloride concentrations in the southernmost Brunswick area.

Graphs of chloride concentrations in water from eight wells tapping different zones of the Floridan aquifer system are included in this report (figs. 107 and 108). Observed variations in chloride concentrations in these wells may be attributed to areal variations in pumping that have altered water-level gradients, and therefore, altered the direction of chloride migration (Clarke and others, 1990, p. 50).

In the southern Brunswick area (fig. 106), high chloride concentrations (greater than $50 \mathrm{mg} / \mathrm{L}$ ) have been recorded since the early 1960's (Gregg and Zimmerman, 1974). The chloride concentrations in water from wells $34 \mathrm{H} 393$ and $34 \mathrm{H} 403$, which tap the upper and lower water-bearing zones of the Upper Floridan aquifer, respectively, do not show long-term trends in chloride concentrations since sampling began in 1968 and 1970, respectively (fig. 107). The chloride concentration in water from well $34 \mathrm{H} 391$ (fig. 107) tapping the brackish-water zone of the Lower Floridan aquifer also does not show a long-term trend since sampling began in 1968. However, the chloride concentration in water from well 34H399 (fig. 107) tapping the brackish-water zone of the Lower Floridan aquifer shows a general upward trend since sampling began in 1970.

In the northern Brunswick area (fig. 106), high chloride concentrations have been recorded since the early-middle 1960's (Gregg and Zimmerman, 1974). The chloride concentrations in water from wells $34 \mathrm{H} 132$ and 34H427, which tap the upper water-bearing zone of the Upper Floridan aquifer, (fig. 108) show a slight upward trend that began in 1988. Prior to this upward trend, chloride concentrations from the two wells show a downward trend that began in 1983 in well $34 \mathrm{H} 427$ and in 1984 in well $34 \mathrm{H} 132$ (fig. 108). The chloride concentrations in water from wells $33 \mathrm{H} 133$ and $33 \mathrm{H} 127$, which tap the upper and lower water-bearing zones of the Upper Floridan aquifer respectively, show an upward trend since sampling began in 1970 (fig. 108). 


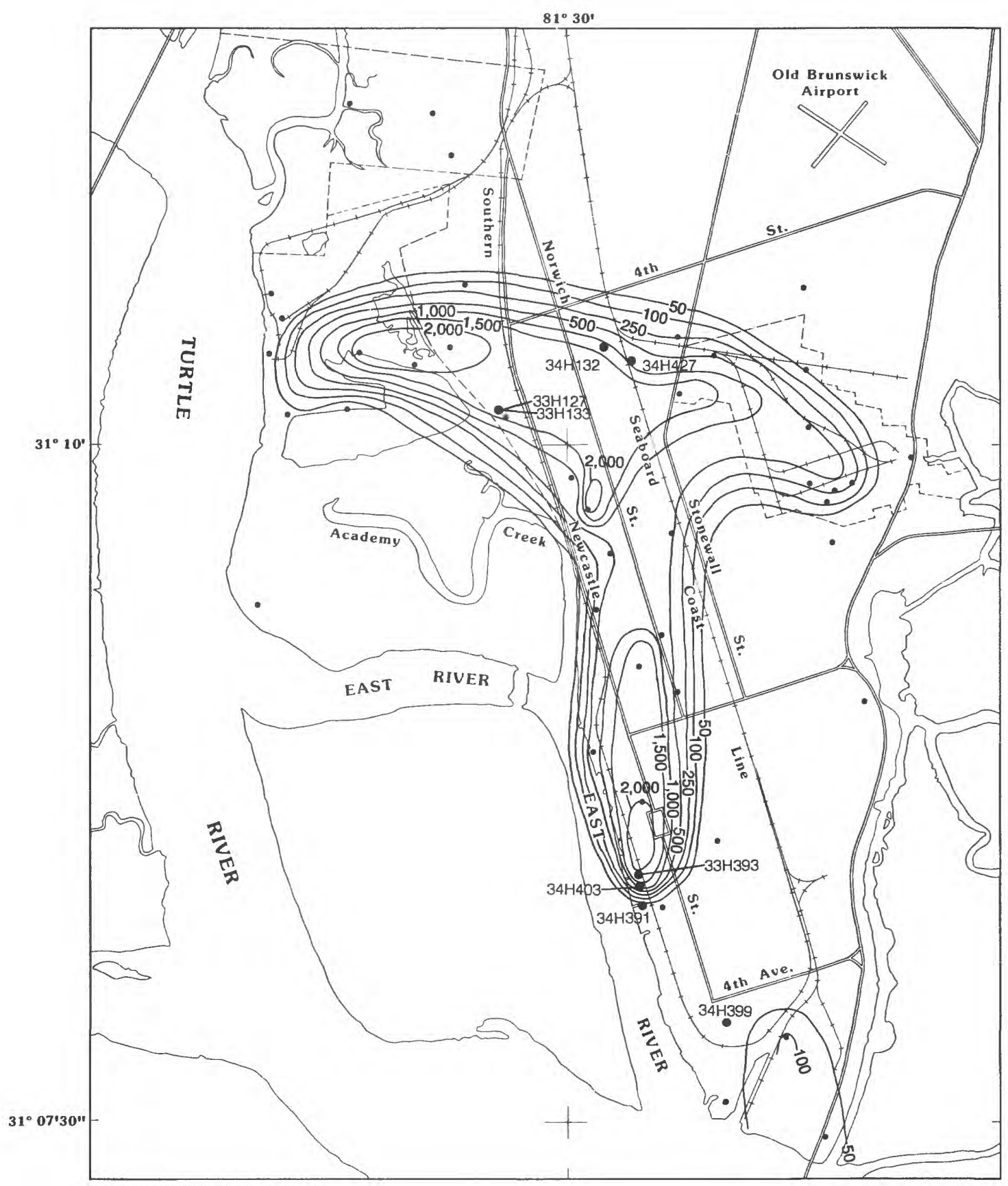

Base from U.S. Geological Survey

Brunswick East 1:24,000, 1979

Brunswick West 1:24.000, 1979

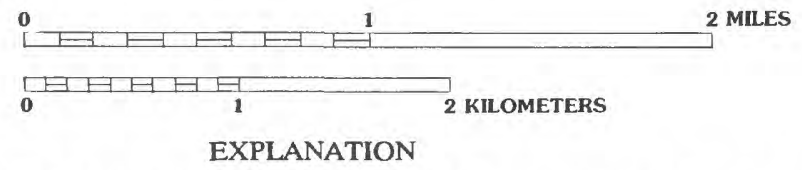

— 100 - LINE OF EQUAL CHLORIDE CONCENTRATION--Interval varies, in milligrams per liter ${ }^{33 H 127}$ OBSERVATION WELL FOR WHICH A CHLORIDE GRAPH IS INCLUDED IN THIS REPORT - DATA POINT

Figure 106.--Chloride concentration in the upper water-bearing zone of the Upper Floridan aquifer and locations of chloride-monitoring wells in the Floridan aquifer system in the Brunswick area, October-November 1990. From Joiner (1991). 

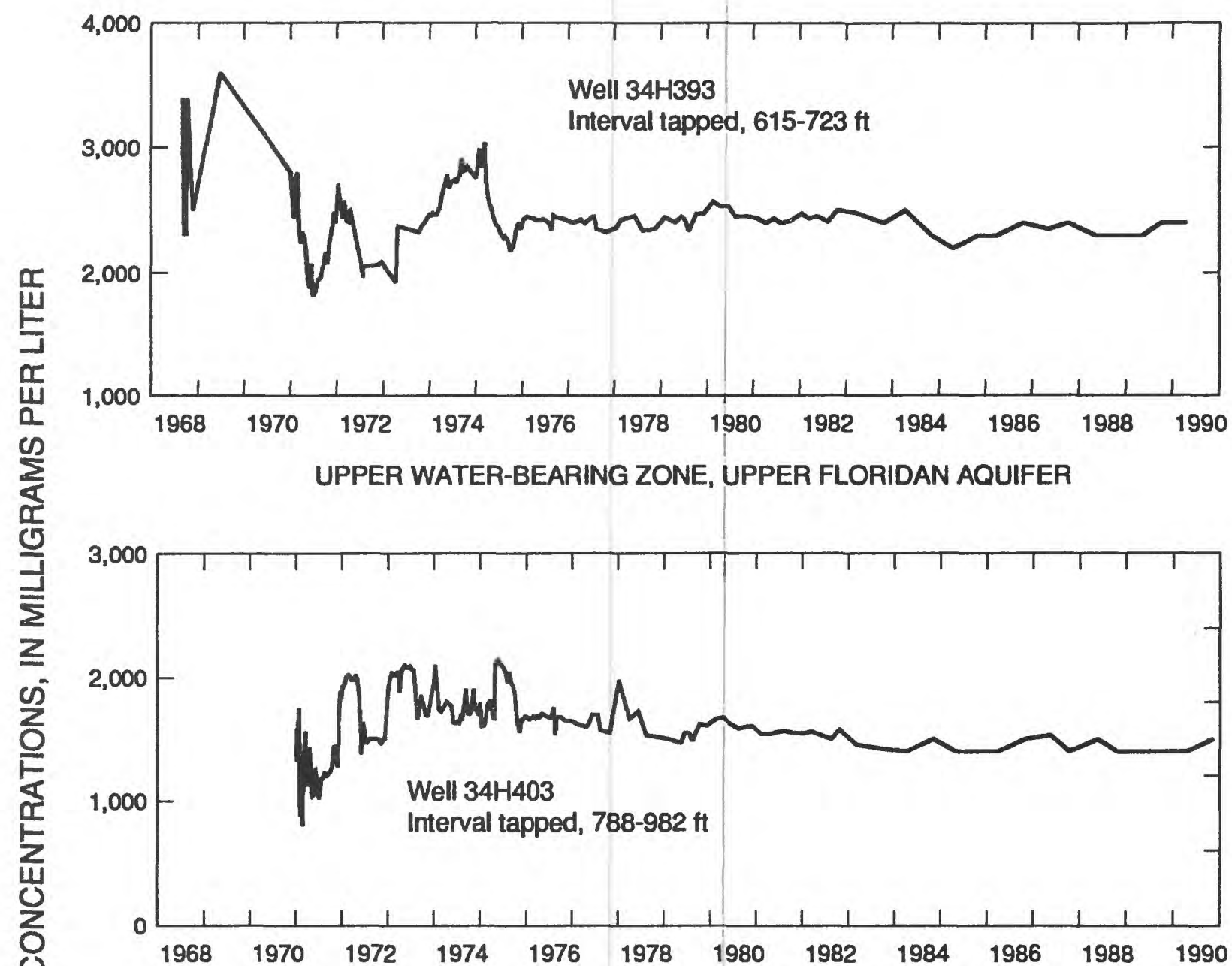

岁

LOWER WATER-BEARING ZONE, UPPER FLORIDAN AQUIFER

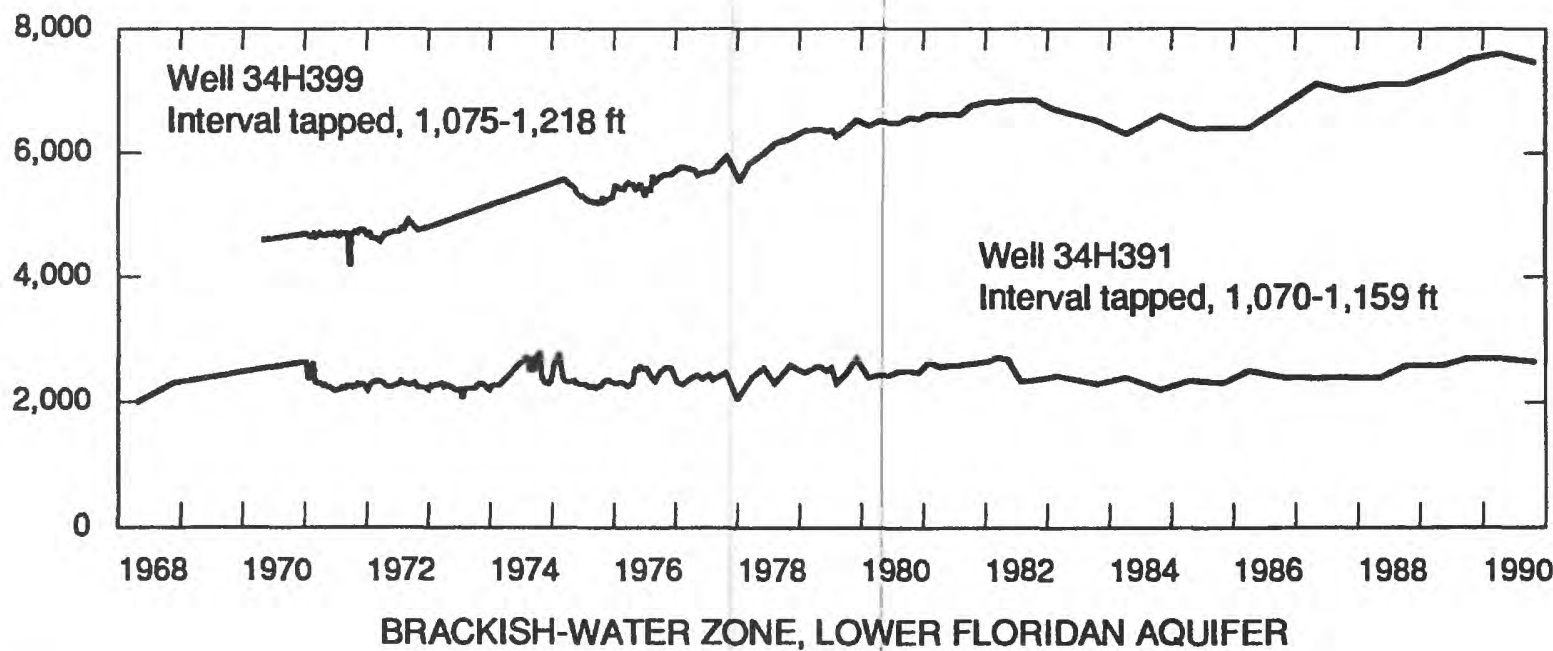

Figure 107.--Chloride concentration in the Floridan aquifer system in the southern Brunswick area. 

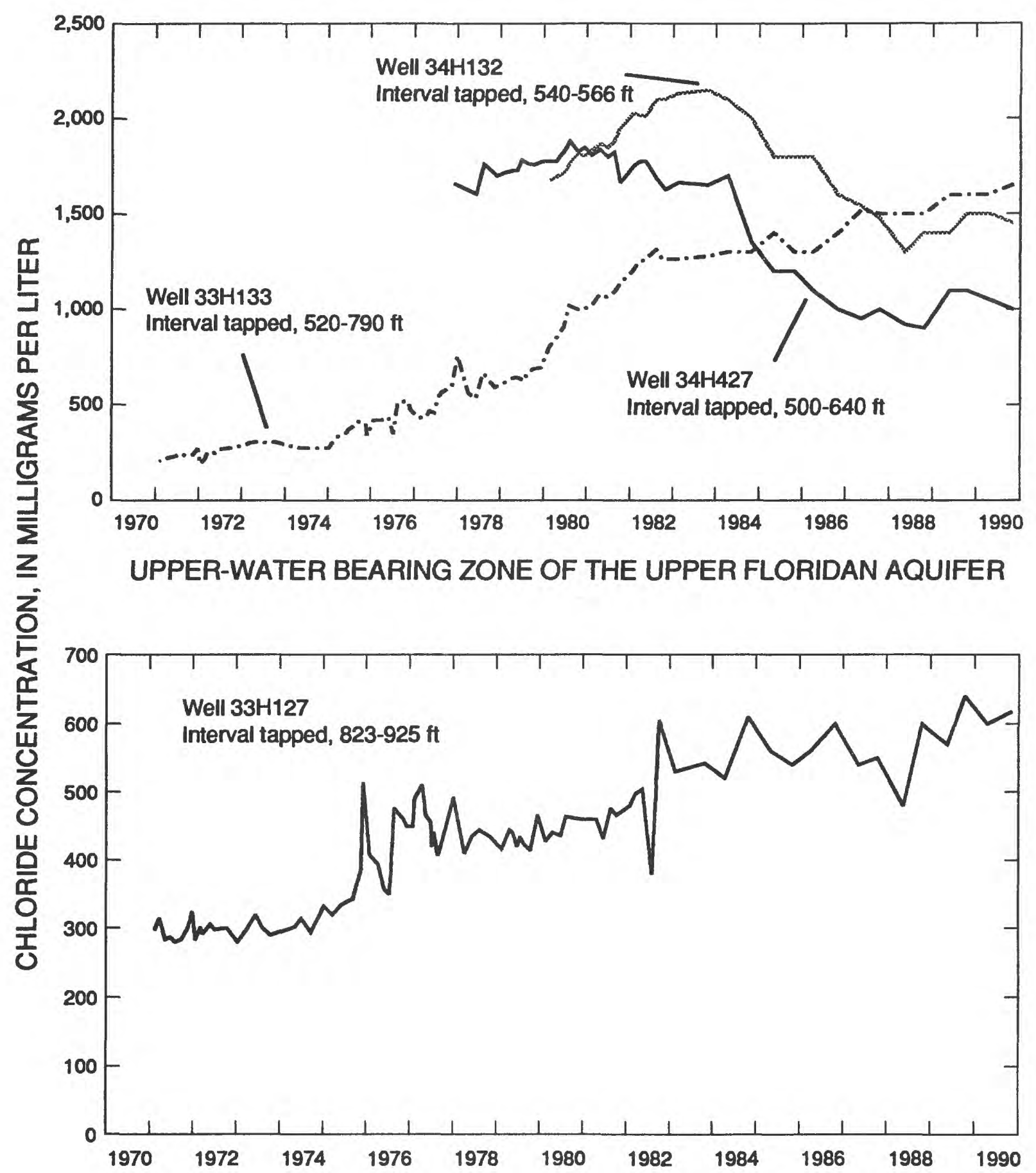

LOWER-WATER BEARING ZONE OF THE UPPER FLORIDAN AQUIFER

Figure 108.-- Chloride concentration in the Floridan aquifer system in the northern Brunswick area. 


\section{REFERENCES CITED}

Burgoon, D.C., 1991, Potentiometric surface of the Upper Floridan aquifer in the Valdosta area, Georgia, October 1990: U.S. Geological Survey Open-File Report 91-207, 3 p.

Carter, R.F., and Stiles, H.R, 1983, Average annual rainfall and runoff in Georgia, 1941-70: Georgia Geologic Survey Hydrologic Atlas 9, 1 sheet.

Clarke, J.S., Brooks, Rebekah, and Faye, R.E., 1985a, Hydrogeology of the Dublin and Midville aquifer system of east-central Georgia: Georgia Geologic Survey Information Circular 74, 62 p.

Clarke, J.S., Longsworth, S.L., McFadden, K.W., and Peck, M.F., 1985b, Ground-water data for Georgia, 1984: U.S. Geological Survey Open-File Report 85-331, 150 p.

Clarke, J.S., Faye, R.E., and Brooks, Rebekah, 1983, Hydrogeology of the Providence aquifer of southwest Georgia: Georgia Geologic Survey Hydrologic Atlas 11, 5 sheets.

Clarke, J.S., Hacke, C.M., and Peck, M.F., 1990, Geology and ground-water resources of the coastal area of Georgia: Georgia Geologic Survey Bulletin 113, 106 p.

Clarke, J.S., Joiner, C.N., Longsworth, S.A., McFadden, K.W., and Peck, M.F., 1986, Ground-water data for Georgia, 1985: U.S. Geological Survey Open-File Report 86-304, 159 p.

Clarke, J.S., and Pierce, R.R., 1984, Ground-water resources of Georgia: Georgia Operator, v. 21, no. 4, p. 1039.

Cressler, A.M., 1991, Chloride concentrations in the Upper Floridan aquifer in the Coastal area, Georgia, May 1990: U.S. Geological Survey Open-File Report 91-173, 1 p.

Georgia Department of Natural Resources, 1977, Rules for safe drinking water: Atlanta: Georgia Department of Natural Resources, Environmental Protection Division, Chapter 391-3-5, p. 601-657.

Gorday, L.L., 1985, The hydrogeology of the Coastal Plain strata of Richmond and northern Burke Counties, Georgia: Georgia Geologic Survey Information Circular 61, 43 p.

Gregg, D.O., and Zimmerman, E.A., 1974, Geologic and hydrologic control of chloride contamination in aquifers at Brunswick, Glynn County, Georgia: U.S. Geological Survey Water-Supply Paper 2029-D, 44 p.

Hayes, R.H., Maslia, M.L., and Meeks, W.C., 1983, Hydrology and model evaluation of the principal artesian aquifer, Dougherty Plain, southwest Georgia: Georgia Geologic Survey Bulletin 97, 93 p.

Joiner, C.N., 1991, Chloride concentrations in the upper water-bearing zone of the Upper Floridan aquifer in the Brunswick area, Georgia October-November 1990: U.S. Geological Survey Open-File Report 91 $174,1 \mathrm{p}$.

Joiner, C.N., Peck, M.F., Reynolds, M.S., and Stayton, W.L., 1989, Ground-water data for Georgia, 1988: U.S. Geological Survey Open-File Report 89-408, 176 p.

Krause, R.E., 1979, Geohydrology of Brooks, Lowndes, and western Echols Counties, Georgia: U.S. Geological Survey Water-Resourses Investigations Report 78-117, 48 p.

Krause, R.E., and Randolph, R.B., 1989, Hydrogeology of the Floridan aquifer system in southeast Georgia and adjacent parts of Florida and South Carolina: U.S. Geological Survey Professional Paper 1403-D, 65 p. 


\section{REFERENCES CITED--Continued}

Marella, R., 1986, Annual water use survey: 1985: St. Johns River Water Management District, Technical Publication SJ 86-5, August 1986, 117 p.

Maslia, M.L., and Prowell, D.C., 1989, Effects of faults on fluid flow and chloride contamination in a carbonate aquifer system: in Journal of Hydrology, 115, p. 1-49.

Milby, B.J., 1991, Potentiometric surface of the Upper Floridan aquifer in the Albany area, Georgia, October 1990: U.S. Geological Survey Open-File Report 91-204, 2 p.

Peck, M.F., 1991, Potentiometric surface of the Upper Floridan aquifer in Georgia and adjacent parts of Alabama, Florida, and South Carolina, May-June 1990: U.S. Geological Survey Open-File Report 91206,3 p.

Peck, M.F., and Allen, R.J., 1991, Potentiometric surface of the Clayton aquifer in Georgia, October 1990: U.S. Geological Survey Open-File Report 91-208, 2 p.

Peck, M.F., Joiner, C.N., Clarke, J.S., and Cressler, A.M., 1990, Ground-water conditions in Georgia, 1989: U.S. Geological Survey Open-File Report 90-706, 125 p.

Pierce, R.R., and Kundell, J.E, 1990, Georgia water supply and use; in Carr, J.E., Chase, E.B., Paulson, R.W., and Moody, D.W., ed.; National Water Summary 1987-Hydrologic events and water supply and use: U.S. Geological Survey Water-Supply Paper 2350, p. 215-222.

Trent, V.P., Fanning, J.L., and Doonan, G.A., 1990, Water use in Georgia by county for 1987: Georgia Geologic Survey Information Circular 85, 112 p.

Turlington, M.C., Fanning, J.L., and Doonan, G.A., 1987, Water use in Georgia by county for 1985: Georgia Geologic Survey Information Circular 81, 110 p.

U.S. Environmental Protection Agency, 1986, Secondary maximum contaminant levels (section 143.3 of part 143, National secondary drinking-water regulations): U.S. Code of Federal Regulations, Title 40, Parts 100 to 149 , revised July 1, 1986, p. 587-590.

U.S. Geological Survey, 1978, Ground-water levels and quality data for Georgia, 1977: U.S. Geological Survey Open-File Report 79-213, 88 p.

U.S. National Oceanic and Atmospheric Administration, 1990, Climatological data, Georgia, JanuaryDecember 1990, v. 94, no. 1-12.

West, C.T., 1991. Potentiometric surface of the Claiborne aquifer in Georgia, October 1990: U.S. Geological Survey Open-File Report 91-205, 2 p. 


\section{PREFACE}

This report was prepared in cooperation with the following agencies, whose assistance in collecting water-level and water-quality data during 1990 are gratefully acknowledged:

Georgia Department of Natural Resources Environmental Protection Division

Georgia Geologic Survey

Albany Water, Gas, and Light Commission

City of Brunswick

Glynn County

Chatham County-Savannah Metropolitan Planning Commission

City of Valdosta

The report is the culmination of a concerted effort by dedicated personnel of the U.S. Geological Survey who collected, compiled, analyzed, verified, and organized the data, and who edited and assembled the report. In addition to the authors, who had primary responsibility for ensuring that the information contained herein is accurate, complete, and adheres to U.S. Geological Survey policy and established guidelines, the following individuals contributed substantially to the collection, processing, tabulation, and review of the data:

\author{
George A. Bailey \\ Carolyn A. Casteel \\ John S. Clarke \\ Darrell D. Dorminey \\ John H. Doss \\ David A. Early \\ Donald J. Everett \\ Willis G. Hester \\ Glen W. Hess
}

\author{
Stephen H. Jones \\ Richard E. Krause \\ Roger D. McFarlane \\ R. Terry Nichols \\ Michael F. Peck \\ Mark S. Reynolds \\ Welby L. Stayton \\ John W. Tyler \\ Blaine T. White
}

Data used in this report may be obtained upon request from the U.S. Geological Survey, Water Resources Division, 6481 Peachtree Industrial Boulevard, Suite B, Doraville, GA 30360. 